\title{
Descriptions of Virus Families and Groups
}

\begin{tabular}{|c|c|c|c|}
\hline Family/Group & Page & Family/Group & Page \\
\hline Adenoviridae & 140 & Marafivirus & 314 \\
\hline Alfalfa mosaic & 392 & Microviridae & 178 \\
\hline Arenaviridae & 284 & Myoviridae & 161 \\
\hline Baculoviridae & 117 & Necrovirus & 316 \\
\hline Birnaviridae & 200 & Nepovirus & 368 \\
\hline Bromovirus & 382 & Nodaviridae & 372 \\
\hline Bunyaviridae & 273 & Orthomyxoviridae & 263 \\
\hline Caliciviridae & 300 & Papovaviridae & 146 \\
\hline Capillovirus & 339 & Paramyxoviridae & 242 \\
\hline Carlavirus & 341 & Parsnip yellow fleck & 318 \\
\hline Carmovirus & 303 & Partitiviridae & 208 \\
\hline Caulimovirus & 150 & Parvoviridae & 167 \\
\hline Closterovirus & 345 & Pea enation mosaic & 375 \\
\hline Commelina yellow mottle & 153 & Phycodnaviridae & 137 \\
\hline Comovirus & 360 & Picornaviridae & 320 \\
\hline Coronaviridae & 234 & Plasmaviridae & 124 \\
\hline Corticoviridae & 157 & Podoviridae & 165 \\
\hline Cryptovirus & 212 & Polydnaviridae & 129 \\
\hline Cucumovirus & 386 & Potexvirus & 348 \\
\hline Cystoviridae & 184 & Potyvirus & 351 \\
\hline Dianthovirus & 364 & Poxviridae & 91 \\
\hline Fabavirus & 366 & Reoviridae & 186 \\
\hline Filoviridae & 247 & Retroviridae & 290 \\
\hline Flaviviridae & 223 & Rhabdoviridae & 250 \\
\hline Furovirus & 377 & Siphoviridae & 163 \\
\hline Geminivirus & 173 & Sobemovirus & 327 \\
\hline Hepadnaviridae & 111 & SSV-1 & 126 \\
\hline Herpesviridae & 103 & Tectiviridae & 155 \\
\hline Hordeivirus & 395 & Tenuivirus & 398 \\
\hline Ilarvirus & 389 & Tetraviridae & 330 \\
\hline Inoviridae & 181 & Tobamovirus & 357 \\
\hline Iridoviridae & 132 & Tobravirus & 380 \\
\hline Leviviridae & 306 & Togaviridae & 216 \\
\hline Lipothrixviridae & 127 & Tombusvirus & 332 \\
\hline Luteovirus & 309 & Totiviridae & 203 \\
\hline Maize chlorotic dwarf & 312 & Tymovirus & 336 \\
\hline
\end{tabular}




\begin{tabular}{|lll}
\hline FAMILY & POXVIRUS GROUP & POXVIRIDAE \\
\hline
\end{tabular}

Reported by J.J. Esposito

Morphology Large, somewhat pleomorphic, brick-shaped or ovoid virion, $220-450 \mathrm{~nm} \times 140-260 \mathrm{~nm}$, with external coat containing lipid and tubular or globular protein structures, enclosing one or two lateral bodies and a core, which contains the genome.

Physicochemical Infectivity ether-resistant in some members, ether-sensitive properties in others.

Nucleic acid

Single molecule of dsDNA, 130-375 kbp; G+C content: vertebrate poxvirus $=35-64 \%$; entomopoxviruses $=20 \%$.

Protein

More than 100 polypeptides detected in the virion. Virion cores contain enzymes concerned with transcription and modification of nucleic acids and proteins.

\section{Lipid}

Carbohydrate

Host range

Transmission
About $4 \%$ by weight (vaccinia).

About 3\% by weight.

\section{REPLICATION}

Multiplication occurs in cytoplasm producing type B inclusion bodies (viroplasms), some members produce protein deposits (occlusions or type A inclusions) that may or may not contain infectious virions. Some genes (early) are expressed before the genome is fully uncoated, others (intermediate and late) during the replicative and postreplicative phases; mRNAs are capped, not spliced, and 5'-polyadenylated (some mRNAs have 3'-polyadenylated leaders). Mature particles released by cellular disruption, some by wrapping in Golgi membranes via exocytosis, and some by extrusion via microvilli. Genetic recombination occurs within genera; nongenetic reactivation occurs both within and between genera of vertebrate poxviruses. Haemagglutinin is separate from the virion and is produced mainly by orthopoxviruses, rare in other genera.

\section{Biological ASPECTS}

Generally narrow in vertebrates or invertebrates.

Airborne, also by contact, fomites, and mechanical by arthropods. 


\section{SUBFAMILIES}

Poxviruses of vertebrates Poxviruses of insects

Chordopoxvirinae

Entomopoxvirinae

\begin{tabular}{lll}
\hline \hline SUBFAMILY & $\begin{array}{l}\text { POXVIRUSES OF } \\
\text { VERTEBRATES }\end{array}$ & CHORDOPOXVIRINAE \\
\hline
\end{tabular}

\section{Properties of the Virus Particle}

Pleomorphic, brick-shaped or ovoid virions chemically like other members of the family Poxviridae. At least 20 major antigens in virion, one of which cross-reacts with most vertebrate poxviruses. Extensive serological crossreactivity within each genus of vertebrate poxviruses, less obvious in Avipoxvirus.

\section{GenerA}

Vaccinia subgroup

Orf subgroup

Fowlpox subgroup

Sheep pox subgroup

Myxoma subgroup

Swinepox subgroup

Molluscum subgroup

Yaba/Tanapox subgroup
Orthopoxvirus

Parapoxvirus

Avipoxvirus

Capripoxvirus

Leporipoxvirus

Suipoxvirus

Molluscipoxvirus

Yatapoxvirus

\begin{tabular}{llc}
\hline \hline GENUS & VACCINIA SUBGROUP & ORTHOPOXVIRUS \\
\hline TYPE SPECIES & VACCINIA VIRUS & - \\
\hline
\end{tabular}

\section{Properties of the Virus Particle}

Morphology Virions brick-shaped, $250-300 \mathrm{~nm}$ x $200 \mathrm{~nm}$ x $250 \mathrm{~nm}$.

Physicochemical Infectivity of virions is ether-resistant. properties

Nucleic acid

Single linear molecule of dsDNA, $\approx 185 \mathrm{kbp}, \mathrm{G}+\mathrm{C} \approx$ $36 \%$, with complementary strands covalently linked at the ends and with sets of tandemly repeated sequences within terminal inverted repetitions.

Protein

Virions released by exocytosis via the Golgi have a single membrane envelope containing several viral proteins. A glycoprotein haemagglutinin is produced in infected cells and becomes incorporated into the host cell Golgi and plasma membrane, thereby into the envelope of virions 
released by exocytosis and by extrusion via microvilli. Virions released by cell lysis lack the cell membranederived envelope and are also infectious. The envelope encloses an external coat, a lipoprotein tegument assembled from proteins and host cell lipids; at the late stage of morphogenesis tubule protein(s) are added. The external coat encases a biconcave core and lateral bodies that are in the concavities of the core. Various enzymes are located within the external coat The core encloses the genome. Proteinaceous A-type cytoplasmic inclusions made by some members may encase infectious virions, depending on strain.

\section{REPLICATION}

Morphogenesis of immature to mature virus particles occurs in type-B cytoplasmic inclusions (viroplasms). Different species undergo genetic recombination and exhibit extensive serological cross-reactivity and nucleic acid homology. Enveloped virions contain distinct neutralization sites compared to lytically released virions and virus particles in A-type inclusions.

\section{Biological Aspects}

Host range Monkeypox, cowpox, and vaccinia (smallpox vaccine) have wide vertebrate host range - others narrow, some limited to a single animal host in nature. All members have wide cell culture host range.

\section{OTHER MEMBERS}

Camelpox (camels)

Cowpox (felines, bovines, humans; rodent reservoir suspected)

Ectromelia (mousepox - isolated only from captive mice)

Monkeypox (humans, monkeys, African arboreal squirrel reservoir suspected)

Raccoonpox (North American raccoon Procyon lotor)

Taterapox (one isolate, African gerbil Tatera kempi)

Variola (humans)

Volepox (from Microtus californicus and Peromyscus truei)

Vaccinia subspecies:

Buffalopox (milking buffalos, cattle, humans)

Rabbitpox (isolated only from captive rabbits)

\section{Probable members}

Uasin Gishu disease (African horses) 


\begin{tabular}{llc}
\hline \hline GENUS & ORF SUBGROUP & PARAPOXVIRUS \\
\hline TYPE SPECIES & ORF VIRUS & - \\
\hline
\end{tabular}

\section{Properties of the Virus Particle}

Morphology Virions ovoid, $220-300 \mathrm{~nm}$ x 140-170 nm; external coat and filaments are thicker than in vaccinia virions and appear as a regular cross-hatched spiral coil of a continuous single thread.

Physicochemical Infectivity is ether-sensitive. properties

Nucleic acid

Antigenic properties
One molecule dsDNA, $130-150 \mathrm{kbp}, \mathrm{G}+\mathrm{C} \approx 64 \%$.

Members show serological cross-reactivity. Hemagglutinin rare, reported for orf and contagious ecthyma isolates.

\section{Biological ASPECTS}

Viruses of ungulates may infect humans, sealpox might infect dog and cat.

\section{OTHER MEMBERS}

Orf virus, synonyms - contagious pustular dermatitis (CPD), contagious ecthyma (sheep, goats, musk oxen, humans).

Stomatitis papulosa (bovines), synonyms - bovine papular stomatitis (BPS).

Pseudocowpox virus (bovines), synonyms - milkers' nodule (humans), paravaccinia (humans, bovines).

\section{Probable members}

Parapoxvirus of New Zealand red deer (30-50\% DNA homology with orf)

Ausduk disease, synonym -camel contagious ecthyma

Chamois contagious ecthyma

Sealpox

\begin{tabular}{llc}
\hline \hline GENUS & FOWLPOX SUBGROUP & AVIPOXVIRUS \\
\hline TYPE SPECIES & FOWLPOX VIRUS & - \\
\hline
\end{tabular}

Morphology

Properties of the Virus Particle

Physicochemical Infectivity is usually ether-resistant. properties 
Nucleic acid

Protein

Lipid

Antigenic properties

Host range

Transmission
One molecule dsDNA, $\approx 260 \mathrm{kbp}$.

Infected cells do not usually produce haemagglutinin.

Certain members produce A-type inclusions with much lipid.

Members show serological cross-reactivity but crossprotection is variable.

\section{Biological ASPECTS}

Viruses of birds, mammalian cell infection is abortive.

Usually mechanical by arthropods.

\section{OTHER MEMbERS}

Canarypox

Juncopox

Pigeonpox

Psittacinepox

Quailpox

Sparrowpox

Starlingpox

Turkeypox

\section{Probable members}

Peacockpox

Penguinpox

Mynahpox

\begin{tabular}{llc}
\hline \hline GENUS & SHEEP POX SUBGROUP & CAPRIPOXVIRUS \\
\hline TYPE SPECIES & SHEEP POX VIRUS & - \\
\hline
\end{tabular}

Properties of The Virus Particle

Morphology Virions brick-shaped, $300 \mathrm{~nm}$ x $270 \mathrm{~nm}$ x $200 \mathrm{~nm}$.

Physicochemical Infectivity is ether-sensitive. properties

Nucleic acid One molecule dsDNA, 150-160 kbp.

Antigenic Members show serological cross-reactivity. properties 


\section{Biological Aspects}

Host range Viruses of ungulates (sheep, goats, cattle).

Transmission Usually mechanical by arthropods, also by contact, fomites and airborne.

\section{OTHER MEMBERS}

Sheeppox

Goatpox

Lumpy skin disease, Synonym-Neethling

\begin{tabular}{llc}
\hline \hline GENUS & MYXOMA SUBGROUP & LEPORIPOXVIRUS \\
\hline TYPE SPECIES & MYXOMA VIRUS & - \\
\hline
\end{tabular}

\section{Properties of the Virus Particle}

Morphology Virions brick-shaped, 250-300 nm x $250 \mathrm{~nm}$ x $200 \mathrm{~nm}$.

Physicochemical Infectivity is ether-sensitive. properties

Nucleic acid One molecule dsDNA, $\approx 160 \mathrm{kbp}, \mathrm{G}+\mathrm{C} \approx 40 \%$.

Antigenic Members show serological cross-reactivity. properties

\section{Biological Aspects}

Host range Viruses of leporids and squirrels, extended range in cell cultures.

Transmission Usually mechanical by arthropods. Causes localized benign tumors in natural hosts, but myxoma viruses cause severe generalized disease in European rabbits.

\section{OTHER MEMBERS}

Hare fibroma

Rabbit (Shope) fibroma

Squirrel fibroma

\section{Probable members}

Malignant rabbit fibroma (natural history uncertain, apparently a myxoma-fibroma recombinant). 


\begin{tabular}{llc}
\hline \hline GENUS & SWINEPOX SUBGROUP & SUIPOXVIRUS \\
\hline TYPE SPECIES & SWINEPOX VIRUS & - \\
\hline
\end{tabular}

\section{Properties of The Virus Particle}

Morphology Virions brick-shaped, size like vaccinia virus.

Nucleic acid One molecular dsDNA, $\approx 170 \mathrm{kbp}$.

\section{Biological Aspects}

Host range Virus of swine, genus apparently contains one distinct member.

\begin{tabular}{llc}
\hline \hline GENUS & $\begin{array}{l}\text { MOLLUSCUM } \\
\text { CONTAGIOSUM } \\
\text { SUBGROUP }\end{array}$ & MOLLUSCIPOXVIRUS \\
\hline TYPE SPECIES & $\begin{array}{l}\text { MOLLUSCUM } \\
\text { CONTAGIOSUM VIRUS }\end{array}$ & - \\
\hline
\end{tabular}

\section{Properties of The Virus Particle}

Morphology Virions brick-shaped, $320 \times 250 \mathrm{~nm}$.

Physicochemical Buoyant density in $\mathrm{CsCl} \approx 1.288 \mathrm{~g} / \mathrm{cm}^{3}$. properties

Nucleic acid One molecule of dsDNA, $\approx 188 \mathrm{kbp}, \mathrm{G}+\mathrm{C} \approx 60 \%, 53.02$ $\pm 1.87 \mu \mathrm{m}$ in length with covalently closed ends and terminal inverted repetitions.

Antigenic properties

Host range

Transmission
Antigenically distinct from other chordopoxviruses. Two virus types are recognised with different DNA restriction patterns.

\section{BIOLOGICAL ASPECTS}

Humans.

Transmission in children by direct contact ; transmission in young adults by sexual contact. Lesions contain enlarged cells with intracytoplasmic inclusions. 


\begin{tabular}{llc}
\hline \hline GENUS & YABA/TANAPOX & YATAPOXVIRUS \\
& VIRUS SUBGROUP & - \\
\hline TYPE SPECIES & YABA MONKEY & - \\
& TUMOR VIRUS & \\
\hline
\end{tabular}

\section{Properties of the Virus Particle}

Morphology

Nucleic acid

Host range
Virions, brick-shaped like vaccinia, double-enveloped virions common (Tanapox).

One molecule of dsDNA, $\approx 146 \mathrm{kbp}, \mathrm{G}+\mathrm{C} \approx 33 \%$, with covalently closed ends.

\section{Biological ASPECTS}

Monkeys, baboons, humans (accidental infection), rabbits (experimentally). Mature lesions in primates are epidermal histiocytomas (tumor-like masses of mononuclear cells).

\section{OTHER MEMBERS}

Tanapox virus (humans, monkeys)

Yaba-like disease virus (monkeys) - Tanapox subspecies.

\begin{tabular}{lll}
\hline \hline SUBFAMILY & $\begin{array}{l}\text { POXVIRUS OF } \\
\text { INSECTS }\end{array}$ & ENTOMOPOXVIRINAE \\
\hline
\end{tabular}

\section{Properties of the Virus Particle}

Pleomorphic, brick-shaped or ovoid virions $170-250 \mathrm{~nm} x$ $300-400 \mathrm{~nm}$; chemically like other members of the family. Virions contain at least 4 enzymes found in vaccinia virus. Virions of several morphological types with globular surface units that give a mulberry-like appearance; some have one lateral body, others two. No serological relationships between viruses of the probable genera or with vertebrate poxviruses. Replicate in cytoplasm of cells of insects in hemocytes or adipose cells, few insect cell cultures support virus growth. Mature virions usually occluded in crystalline proteinaceous occlusion bodies. Subdivision into probable genera based on virion morphology, host range, and genome molecular weight of a few isolates.

\section{Probable Genera}

Genus A

Entomopoxvirus A

Genus B

Entomopoxvirus B

Genus C 


\begin{tabular}{llc}
\hline \hline PROBABLE & POXVIRUS OF & ENTOMOPOXVIRUS A \\
GENUS & COLEOPTERA & \\
\hline TYPE SPECIES & POXVIRUS OF & - \\
& MELOLONTHA & \\
& MELOLONTHA & \\
\hline
\end{tabular}

Morphology Virions ovoid, $450 \mathrm{~nm} \times 250 \mathrm{~nm}$, with one lateral body and unilateral concave core; globular surface units $22 \mathrm{~nm}$ in diameter.

Nucleic acid One molecule dsDNA, 260-370 kbp.

\section{OTHER MEMBERS}

Partial listing of members isolated from the following:

Coleoptera: $\quad$ Anomala cuprea Aphodius tasmaniae Demodema boranensis Dermolepida albohirtum

Figulus sublaevis Geotrupes sylvaticus

\begin{tabular}{llcc}
\hline \hline PROBABLE & POXVIRUS OF & ENTOMOPOXVIRUS & $\boldsymbol{B}$ \\
GENUS & LEPIDOPTERA & \\
& AND ORTHOPTERA & \\
\hline TYPE SPECIES & POXVIRUS OF & \\
& AMSACTA MOOREI & \\
& (LEPIDOPTERA) & \\
\hline
\end{tabular}

\section{Properties of The Virus Particle}

Morphology Virions ovoid, $350 \mathrm{~nm}$ x $250 \mathrm{~nm}$, with a sleeve-shaped lateral body and cylindrical core; globular surface units 40 $\mathrm{nm}$ in diameter.

Nucleic acid One molecule dsDNA, $\approx 225 \mathrm{kbp} ; \mathrm{G}+\mathrm{C} \approx 18.5 \%$.

Protein Infected cells synthesise a $116 \mathrm{kDa}$ occlusion protein monomer. 


\section{OTHER MEMBERS}

Partial listing of members isolated from the following:

Lepidoptera: $\quad$ Acrobasis zelleri Choristoneura biennis Choristoneura conflicta Choristoneura diversuma Chorizagrotis auxiliaris Operophtera brumata

Orthoptera: $\quad$ Arphia conspersa Locusta migratoria Melanoplus sanguinipes Oedaleus senugalensis Schistocerca gregaria

\begin{tabular}{llc}
\hline \hline PROBABLE & POXVIRUS OF & ENTOMOPOXVIRUS C \\
GENUS & DIPTERA & \\
\hline TYPE SPECIES & POXVIRUS OF & - \\
& CHIRONOMUS LURIDUS \\
& $($ DIPTERA $)$ & \\
\hline
\end{tabular}

\section{Properties of the Virus Particle}

Morphology Virions brick-shaped, $320 \mathrm{~nm} \times 230 \mathrm{~nm} \times 110 \mathrm{~nm}$, with two lateral bodies and biconcave core.

Nucleic acid One molecule dsDNA, 250-380 kbp.

\section{OTHER MEMBERS}

Partial listing of similar members isolated from the following:

Diptera: $\quad$ Aedes aegypti

Camptochironomus tentans

Chironomus attenuatus

Chironomus plumosus

Goeldichironomus holoprasimus

OTHER MEMBERS OF FAMILY POXVIRIDAE

Not yet allocated to genera, little information available:

Albatrosspox (probably Avipoxvirus)

Cotia (mosquito transmitted to rodent, reservoir unknown) $\mathrm{Embu}$ (mosquito transmitted to rodent, reservoir unknown) 
Marmosetpox (virion morphology like Yatapoxvirus)

Marsupialpox (Australian 'quokkas')

Mule deer poxvirus (USA - Odocoileus hemionus, probably Capripoxvirus)

Volepox (USSR - Microtus oeconomus, Canada-Microtus pennsylvanicus)

Skunk poxvirus (USA - Mephitis mephitis, probably Orthopoxvirus).

Derivation of Names pox: from old English poc, pocc-, plural of pock 'pustule, ulcer' ortho: from Greek orthos, 'straight, correct'

avi: from Latin avis, 'bird'

capri: from Latin caper, capri, 'goat'

lepori: from Latin lepus, leporis, 'hare'

para: from Greek para, 'by side of'

entomo: from Greek entomon, 'insect'

sui: from Latin sus, 'swine'

molluscum: from Latin molluscum, 'clam, snail'

\section{REFERENCES}

Baxby, D.: Poxviruses. In Brown, F. (ed.), Principles of Bacteriology, Virology and Immunity, Vol. 4, 7th edn., (Arnold, London, 1984).

Bugert, J.; Rosen-Wolf, A.; Darai, G.: Genomic characterization of Molluscum contagiosum virus type I: Identification of repetitive DNA sequences in the viral genome. Virus Genes 3:159-173 (1989).

Cooley, A.J.; Reinhard, M.K.; Gross, T.L.; Fadok, V.A.; Levy, M.: Molluscum contagiosum in a horse with granulomatous enteritis. J. Comp. Pathol. 97: 29-34 (1987).

Dales, S.; Pogo, B.G.T.: Biology of Poxviruses. (Springer, Wien, New York, 1981).

Descoteaux, J-P.; Mihok, S.: Serologic study of the prevalence of murine viruses in a population of wild meadow voles (Microtus pennsylvanicus). J. Wildlife Dis. 22: 314319 (1986).

Dumbell, K.R.: Poxviridae. In Porterfield, J. (ed.), Andrews' Viruses of Vertebrates. 5th edn., pp. 395-427 (Bailliere Tindall, London, 1989).

Earl, P.L.; Moss, B.: Vaccinia virus. In "Genetic Maps 1989", pp. 1.138-1.148 (Cold Spring Harbor, New York, 1989).

Esposito, J.J.; Palmer, E.L.; Borden, E.C.; Harrison, A.K.; Obijeski, J.F.; Murphy, F.A.: Studies on the poxvirus Cotia. J. gen. Virol. 47:37-46 (1980).

Fenner, F.; Henderson, D.A.; Arita, I.; Jezek, Z.; Ladnyi, I.D.: Smallpox and Its Eradication. (The World Health Organization, Geneva, 1988).

Fenner, F.; Nakano, J.H.: Poxviridae: The Poxviruses. In Lennette, E.H.; Halonen, P.; Murphy, F.A. (eds.), Laboratory Diagnosis of Infectious Diseases: Principles and Practice. Vol. 2, Viral, Rickettsial, and Chlamydial Diseases, pp. 177-207 (Springer, Berlin, Heidelberg, New York, Tokyo, 1988).

Fenner, F.; Wittek, R.; Dumbell, K.R.: The Orthopoxviruses (Academic Press, New York, 1989).

Gershon, P.D.; Black, D.N.: A comparison of the genomes of Capripoxvirus isolates of sheep, goats, and cattle. Virology 164: 341-349 (1988).

Goebel, S.J.; Johnson, G.P.; Perkus, M.E.; Davis, S.W.; Winslow, J.P.; Paoletti, E.: The complete DNA sequence of Vaccinia virus. Virology 179:247-266 and 517-563 (1990).

Gough, A.W.; Barsoum, N.J.; Gracon, S.T.; Mitchel, L.; Sturgess, J.M.: Poxvirus infection 
in a colony of common marmosets (Callithrix jacchus). Lab. Animal Sci. 32:87-90 (1982).

Granados, R.R.: Entomopoxvirus infections in insects. In Davidson, I. (ed.), Pathogenesis of Invertebrate Microbial Diseases, pp. 101-129 (Allenheld Osmu, Totowa, New Jersey, 1981).

Jezek, Z.; Arita, I.; Szczeniowski, M.; Paluku, K.M.; Ruti, K.; Nakano, J.H.: Human Tanapox in Zaire: Clinical and epidemiological observations on cases confirmed by laboratory studies. Bull. W.H.O. 63: 1027-1035 (1985).

Jezek, Z.; Fenner, F.: Human monkeypox. Monographs in Virology, Vol. 17 (Karger, Basel, 1988).

Kaminjolo, J.S.; Winqvist, G.: Histopathology of skin lesions in Uasin Gishu skin disease in horses. J. Comp. Pathol. 85: 391-395 (1975).

Kilpatrick, D.; Rouhandeh, H.: The analysis of Yaba monkey tumor virus DNA. Virus Res. 7: 151-157 (1987).

Knight, J.C.; Novembre, F.J.; Brown, D.R.; Goldsmith, C.S.; Esposito, J.J.: Studies on Tanapox virus. Virology 172: 116-124 (1989).

McFadden, G.: Poxviruses of Rabbits. In Darai, G. (ed.), Virus Diseases in Laboratory and Captive Animals, pp. 37-61 (Martinus Nijhoff, Boston ,1988).

McKenzie, R.A.; Fay, F.R.; Prior, H. C.: Poxvirus infection of the skin of an eastern grey kangaroo. Aust. Vet. J. 55: 188-190 (1979).

Moens, Y.; Kombe, A.H.: Molluscum contagiosum in a horse. Equine Vet. J. 20: 143-145 (1988).

Moss, B.: Poxviridae and Their Replication. In Fields, B.N.; Knight, J.C. (eds.), Virology, Vol. 2, 2nd edn., pp. 2079-2111 (Raven Press, New York, 1990).

Nakano, J.H.; Esposito, J.J.: Poxviruses. In Schmidt, N.J.; Emmons, R.W. (eds.), Diagnostic Procedures for Viral, Rickettsial, and Chlamydial Infections, 6th edn., pp. 224-265 (American Public Health Association, Washington, D.C., 1989).

Porter, C.D.; Muhlemann, M.F.; Cream, J.J.; Archard, L.C.: Molluscum contagiosum: Characterization of viral DNA and clinical features. Epidemiol. Infect. 99: 563-567 (1987).

Robinson, A.J.; Lyttle, D.J.: Parapoxviruses: Their biology and potential as recombinant vaccines. In Bins, M.; Smith, G., (eds.), Poxviruses as vaccine vectors (CRC Press, Boca Raton, Fl.) In press.

Roslaykov, A.A.: Comparative ultrastructure of viruses of camelpox, pox-like disease of camels (Ausduk) and contagious ecthyma of sheep. Voprosy Virusologii 7:26-30 (1972).

Rouhandeh, H.; Kilpatrick, D; Vafai, A.: The molecular biology of Yaba tumor poxvirus: Analysis of lipids, proteins and DNA. J. gen. Virol. 62:207-218 (1982).

Scholz, J.; Rosen-Wolff, A.; Bugert, J.; Reisner, H.; White, M.I.; Darai, G.; Postlethwaite, R.: Epidemiology of molluscum contagiosum using genetic analysis of the viral DNA. J. Med. Virol. 27: 87-90 (1989).

Tripathy, D.N.: Pox. In Calnek, B.W., Barnes, H.J., Beard, C.W., Reld, W.M., Yoder, H.W. (eds.), Diseases of Poultry., 9th edn., pp. 583-596 (Iowa State University Press, Ames, Iowa, 1990).

Tripathy, D.N.; Hanson, L.E.; Crandall, R.A.: Poxviruses of Veterinary Importance: Diagnosis of Infections. In Kurstak, E.; Kurstak, C., (eds.), Comparative Diagnosis of Viral Diseases. Vol. 3, pp. 267-346 (Academic Press, New York, 1981).

Williams, E.S.; Becerra, V.M.; Thorne, E.T.; Graham, T.J.; Owens, M.J.; Nunmaker, C.E.: Spontaneous poxviral dermatitis and keratoconjunctivitis in free-ranging mule deer (Odocoileus hemionus) in Wyoming. J. Wildlife Dis. 21: 430-432 (1985).

Wilson, T.M.; Dykes, R.W.; Tsai, K.S.: Pox in young captive harbor seals. JAVMA 161:611-617 (1972).

Winterfield, R.W.; Reed, W.: Avian Pox: Infection and immunity with quail, psittacine, fowl, and pigeon pox viruses. Poultry Science 64:65-70 (1985).

Wokatsch, R.: Vaccinia viruses and Variola viruses. In Majer, M.; Plotkin, S.A. (eds.), Strains of Human Viruses, pp. 240-268 (Karger, New York, 1972) 


\section{\begin{tabular}{lll}
\hline FAMILY HERPESVIRUS GROUP & HERPESVIRIDAE
\end{tabular}}

Reported by B. Roizman

Morphology

\section{Properties of the Virus Particle}

The virion, $120-200 \mathrm{~nm}$ in diameter, consists of 4 structural components. The core consists of a fibrillar spool on which the DNA is wrapped. The ends of the fibers are anchored to the underside of the capsid shell. The capsid, 100-110 nm in diameter, has 162 capsomeres arranged as an icosahedron. (150 hexameric and 12 pentameric capsomeres). Capsomeres are hexagonal in cross-section with a hole running half-way down the long axis. The tegument surrounding the capsid consists of globular material which is frequently asymmetrically distributed and may be variable in amount. The envelope, a bilayer membrane surrounding the tegument, has surface projections. The intact envelope is impermeable to negative stain.

Physicochemical properties

Nucleic acid

Protein

Lipid

Carbohydrate

Antigenic properties

Effect on cells
$\mathrm{MW}>1,000 \times 10^{6}$; buoyant density in $\mathrm{CsCl}=1.20$ $1.29 \mathrm{~g} / \mathrm{cm}^{3}$.

One molecule of dsDNA, $120-220 \mathrm{kbp}, \mathrm{G}+\mathrm{C} \approx 35-75 \%$

More than 20 structural proteins, $\mathrm{MW}=12,000->$ 222,000 .

Probably variable; located in virion envelope.

Present, largely as glycoproteins in envelope.

The virion contains several surface glycoproteins. Neutralizing antibody reacts with major viral envelope glycoproteins. An Fc receptor may be present in the envelope.

In the absence of replication, fusion and agglutination occur rarely or under very special conditions

\section{REPLICATION}

The viral envelope attaches to receptors on the plasma membrane of the host cell, fuses with the membrane, and releases the capsid which is transported to the nuclear pore. A DNA-protein complex is transported into the nuclear pore where the DNA circularizes. 
Viral DNA is transcribed in the nucleus and the mRNA is translated in the cytoplasm. Viral DNA is replicated in the nucleus. Unit length DNA is cleaved from concatemers and spooled into preformed, immature capsids which mature by acquisition or processing of proteins that bind to the surface of the capsid.

The ability to infect cells is acquired as capsids are enveloped by budding through the inner lamella of the nuclear membrane. The virus accumulates in the perinuclear space and cisternae of the endoplasmic reticulum. Virus particles are released by transport to the cell surface through modified endoplasmic reticulum in structures bounded by cytoplasmic membranes.

\section{Biological ASPECTS}

Host range

Each virus has its own natural and experimental host range. Both warm and cold-blooded vertebrates and invertebrates are hosts to herpesviruses. Some herpesviruses have been reported to induce neoplasia both in their natural hosts and in experimental animals. In cell culture, some herpesviruses have been reported to convert cell strains into continuous cell lines which may cause invasive cancers in appropriate experimental hosts.

Transmission For many herpesviruses, transmission is by contact between moist mucosal surfaces. Some herpesviruses can be transmitted transplacentally, intrapartum, via breast milk, or by transfusions. Some, are probably also transmitted by airborne and waterborne routes. Herpesviruses may remain latent in their primary hosts for the lifetime of those hosts; cells harboring latent virus may vary depending on the virus.

\section{SUBFAMILIES}

Herpes simplex virus group

Cytomegalovirus group

Alphaherpesvirinae

Lymphoproliferative virus group 


\begin{tabular}{lll}
\hline \hline SUBFAMILY & $\begin{array}{l}\text { HERPES SIMPLEX } \\
\text { VIRUS }\end{array}$ & ALPHAHERPESVIRINAE \\
\hline
\end{tabular}

\section{Properties of The Virus Particle}

Nucleic acid DNA $=120-180 \mathrm{kbp}$. The sequences from both or either terminus are present in an inverted form internally. The DNA packaged in virions may consist of two or four isomeric forms. Natural isolates may exhibit restriction endonuclease cleavage site polymorphism.

\section{REPLICATION}

Relatively short $(<24 \mathrm{~h})$ replicative cycle.

\section{Biological Aspects}

Host range Variable, from very wide to very narrow.

Cytopathology Rapid spread of infection in cell culture results in mass destruction of susceptible cells. Establishment of carrier cultures of susceptible cells harboring nondefective genomes difficult to accomplish.

Latent infections Latent infections frequently but not exclusively demonstrated in sensory and autonomic ganglia.

\section{GENERA}

Human herpesvirus 1 group Simplexvirus Human herpesvirus 3 group Varicellovirus

\begin{tabular}{llc}
\hline \hline GENUS & HUMAN HERPESVIRUS & SIMPLE XVIRUS \\
& 1 GROUP & - \\
\hline TYPE SPECIES & HUMAN (ALPHA) & \\
& HERPESVIRUS 1 & \\
& (HERPES SIMPLEX VIRUS 1) & \\
\hline
\end{tabular}

\section{Properties of the Virus Particle}

Nucleic acid $\quad \mathrm{DNA} \approx 152 \mathrm{kbp}, \mathrm{G}+\mathrm{C} \approx 67 \%$. Sequences from both termini are repeated in an inverted form internally; virion DNA exists in 4 isomeric forms and shares $>50 \%$ of its sequences with human (alpha) herpesvirus 2 DNA under stringent hybridization conditions.

Protein $>30$ structural proteins, including 8 glycoproteins. 
Antigenic properties

Host range
At least 3 glycoproteins are capable of inducing neutralizing antibody.

\section{Biological Aspects}

Recovered in nature only from humans, but the virus may sustain itself and be transmitted in captive non-human primate colonies. Experimental host range, very wide.

\section{OTHER MEMBERS}

Human (alpha) herpesvirus 2 (herpes simplex virus 2)

Bovine (alpha) herpesvirus 2 (bovine mammillitis virus)

\begin{tabular}{llc}
\hline \hline GENUS & HUMAN HERPESVIRUS 3 & VARICELLOVIRUS \\
& GROUP & - \\
\hline TYPE SPECIES & HUMAN (ALPHA) & \\
& HERPESVIRUS 3 & \\
& (VARICELLA-ZOSTER VIRUS) & \\
\hline
\end{tabular}

\section{Properties of The Virus Particle}

Nucleic acid DNA $\approx 125 \mathrm{kbp}$. DNA sequences from one terminus are repeated in an inverted form internally. Virion DNA exists in 2 isomeric forms.

\section{Biological ASPECTS}

Host range Recovered only from humans. Experimental host range may vary from broad to highly restricted.

\section{OTHER MEMBERS}

Suid (alpha) herpesvirus 1 (pseudorabies virus)

Bovine (alpha) herpesvirus 1 (infectious bovine rhinotracheitis virus)

Equid (alpha) herpesvirus 1 (equine abortion virus)

Equid (alpha) herpesvirus 4 (respiratory infection virus)

\section{Probable members}

Cercopithecid herpesvirus 1 (B virus)

Equid herpesvirus 3 (coital exanthema)

Felid herpesvirus 1 (feline herpesvirus)

Canid herpesvirus (canine herpesvirus) 


\begin{tabular}{ll}
\hline \hline SUBFAMILY & $\begin{array}{l}\text { CYTOMEGALOVIRUS } \\
\text { GROUP }\end{array}$ \\
\hline
\end{tabular}

\section{Properties of The Virus Particle}

Nucleic acid $\mathrm{DNA}=180-250 \mathrm{kbp} ; \mathrm{G}+\mathrm{C} \approx 56 \%$. Sequences from either or both termini may be present in an inverted form internally.

\section{REPLICATION}

Relatively slow reproductive cycle $(>24 \mathrm{~h})$. Slowly progressing lytic foci in cell culture. Enlargement of the infected cell in vivo and often in vitro (cytomegalia). Inclusion bodies containing DNA may be present in nuclei and cytoplasm late in infection. Carrier cultures easily established.

\section{Biological Aspects}

Host range In vivo - narrow, frequently restricted to the species or genus to which the host belongs. In vitro - replication may be restricted to a specific cell type, but exceptions exist.

Latent infections Possibly in secretory glands, lymphoreticular cells, and kidneys and other tissues.

\section{GENERA}

Human cytomegalovirus group Cytomegalovirus Murine cytomegalovirus group Muromegalovirus

\begin{tabular}{lll}
\hline \hline GENUS & HUMAN & CYTOMEGALOVIRUS \\
& CYTOMEGALOVIRUS & \\
& GROUP \\
\hline TYPE SPECIES & HUMAN (BETA) & - \\
& HERPESVIRUS 5 & \\
& (HUMAN CYTOMEGALOVIRUS) & \\
\hline
\end{tabular}

\section{Properties of The Virus Particle}

\section{Nucleic acid $\quad D N A \approx 200 \mathrm{kbp}$.}

\section{Biological ASPECTS}

Virus recovered only from human infections. Experimental host range narrow; grows best in human fibroblasts and less well in certain human lymphoblastoid cells. 


\begin{tabular}{llc} 
Taxonomic status & English vernacular name & International name \\
\hline \hline GENUS & MURINE & MUROMEGA LOVIRUS \\
& CYTOMEGALOVIRUS & \\
& GROUP & - \\
\hline TYPE SPECIES & MURID (BETA) & \\
& HERPESVIRUS 1 & \\
& (MOUSE CYTOMEGALOVIRUS) & \\
\end{tabular}

\section{Properties of the Virus Particle}

Nucleic acid $\quad \mathrm{DNA} \approx 200 \mathrm{kbp}$.

Possible members

Suid herpesvirus 2 (pig cytomegalovirus)

Equid herpesvirus 2

Murid herpesvirus 2 (rat cytomegalovirus)

Caviid herpesvirus 1 (guinea pig cytomegalovirus)

\begin{tabular}{lll}
\hline \hline SUBFAMILY & LYMPHO- & GAMMAHERPESVIRINAE \\
& PROLIFERATIVE & \\
& VIRUS GROUP & \\
\hline
\end{tabular}

\section{Properties of The Virus Particle}

Nucleic acid $\quad \mathrm{DNA} \approx 170 \mathrm{kbp}$; both ends of the molecule contain reiterated sequences that are not reiterated internally.

\section{REPLICATION}

Duration of the reproductive cycle is variable. All members replicate in lymphoblastoid cells, and some will also cause lytic infections in some types of epithelioid and fibroblastic cells. Viruses are specific for either B- or Tlymphocytes; in the lymphocyte, infection is frequently arrested at a prelytic stage, with persistence and minimum expression of the viral genome in the cell (latent infection), or at a lytic stage, causing death of the cell without production of complete virions. Latent infection is frequently demonstrated in lymphoid tissue.

\section{Biological ASPECTS}

Host range Narrow; experimental hosts usually limited to the same order as the host it naturally infects.

Cytopathology Variable.

\section{GENERA}

Human herpesvirus 4 group

Ateline herpesvirus group 


\begin{tabular}{lll}
\hline \hline GENUS & HUMAN & LYMPHOCRYPTOVIRUS \\
& $\begin{array}{l}\text { HERPESVIRUS 4 } \\
\text { GROUP }\end{array}$ & \\
\hline TYPE SPECIES & HUMAN (GAMMA) & - \\
& $\begin{array}{l}\text { HERPESVIRUS 4 } \\
\text { (EPSTEIN-BARR VIRUS) }\end{array}$ \\
\hline
\end{tabular}

\section{Properties of The Virus Particle}

Nucleic acid $\quad \mathrm{DNA} \approx 170 \mathrm{kbp}$; some isolates lack as much as $15 \mathrm{kbp}$ at specific sites.

\section{Biological Aspects}

Virus shows specificity for B-lymphocytes.

\section{OTHER MEMBERS}

Pongine herpesvirus 1 (Chimpanzee herpesvirus)

Cercopithecine herpesvirus 2 (Baboon herpesvirus)

\begin{tabular}{llc}
\hline \hline GENUS & $\begin{array}{l}\text { ATELINE HERPESVIRUS } \\
\text { GROUP }\end{array}$ & RHADINOVIRUS \\
\hline TYPE SPECIES & $\begin{array}{l}\text { ATELINE HERPESVIRUS 2 } \\
\text { (HERPESVIRUS ATELES) }\end{array}$ & - \\
\hline
\end{tabular}

\section{Properties of The Virus Particle}

Nucleic acid DNA $\approx 105 \mathrm{kbp}$; stretch of quasi unique sequences low in GC content flanked at both ends with numerous repeat sequences of high $\mathrm{GC}$ content.

\section{Biological Aspects}

Host range variable but restricted to New World primates. Grows in a variety of cells in culture.

\section{OTHER MEMBERS}

Saimirine herpesvirus 1

Derivation of herpes: from Greek herpes, herpetos, 'creeping, Name crawling creature'; from nature of herpes febrilis lesions. 


\section{REFERENCES}

Baer, R.; Bankier, A.T.; Biggin, M.D.; Deininger, P.L.; Farrell, P.J.; Gibson, T.J.; Hatfull, G.; Hudson, G.S.; Satchwell, S.C.; Seguin, C.; Tuffnell, P.S.; Barrell, B.G.: DNA sequence and expression of the B95-8 Epstein-Barr virus genome. Nature 310:207-211 (1984).

Bornkamm, G.W.; Delius, H.; Fleckenstein, B.; Werner, F.-J.; Mulder, C.: Structure of Herpesvirus saimiri genomes: arrangement of heavy and light sequences in the $M$ genome. J. Virol. 19:154-161 (1976).

Buchman, T.G.; Roizman, B.: Anatomy of bovine mammillitis DNA. II. Size and arrangements of the deoxynucleotide sequences. J. Virol. 27:239-254 (1978).

Buchman, T.G.; Roizman, B.; Nahmias, A.J.: Demonstration of exogenous genital reinfection with herpes simplex virus type 2 by restriction endonuclease fingerprinting of viral DNA. J. Infect. Dis. 140:295-304 (1979).

Davison, A.J.; Scott, J.E.: The complete DNA sequence of Varicella-zoster virus. J. gen. Virol. 67:1759-1816 (1986).

Fleckenstein, B.; Bornkamm, G.W.; Mulder, C.; Werner, F.-J.; Daniel, M.D.; Falk, L.A.; Delius, H.: Herpesvirus ateles DNA and its homology with Herpesvirus saimiri nucleic acid. J. Virol. 25:361-373 (1978).

Kilpatrick, B.A.; Huang, E.-S.: Human cytomegalovirus genome: partial denaturation map and organization of genome sequences. J. Virol. 24:261-276 (1977).

McGeoch, D.J.; Dalrymple, J.M.; Davison, A.J.; Dolan, A.; Frame, M.C.; McNab, D.; Perry, L.J.; Scott, J.E. and Taylor, P.: The complete DNA sequence of the long unique region in the genome of herpes simplex virus type 1. J. gen. Virol. 69: 1531-1574 (1988).

McGeoch, D.J.; Dolan, A.; Donald, S.; Brauer, D.H.K.: Complete DNA sequence of the short repeat region in the genome of herpes simplex virus type 1. Nuc. Acids Res. 14: 17271745 (1986).

McGeoch, D.J.; Dolan, A.; Donald, S.; Rixon, F.J.: Sequence determination and genetic content of the short unique region in the genome of herpes simplex virus type 1 . J. Mol. Biol. 181: 1-13 (1985).

Mosmann, T.R.; Hudson, J.B.: Some properties of the genome of murine cytomegalovirus (MCV). Virology 54:135-149 (1973).

Roizman, B,: Herpesviridae: a brief introduction. In Fields, B.N.; Knipe, D.M., (eds.), Virology, Vol. 2, 2nd edn., pp. 1787-1794, (Raven Press, New York, 1990).

Roizman, B.; Sears, A.E.: Herpes simplex viruses and their replication. In Fields, B.N.; Knipe, D.M., (eds.), Virology, Vol. 2, 2nd edn., pp. 1795-1841 (Raven Press, New York, 1990).

Roizman, B.; Batterson, W.: The replication of herpesviruses. In Fields, B.N.; Knipe, D.M.; Chanock, R.M.; Roizman, B.; Melnick, J.L.; Shope, R.E. (eds), Virology, pp. 497-526 (Raven Press, New York, 1985).

Roizman, B.; Carmichael, L.E.; Deinhardt, F.; de-The, G.; Nahmias, A.J.; Plowright, W.; Rapp, F.; Sheldrick, P.; Takahashi, M.; Wolf, K.: Herpesviridae: definition, provisional nomenclature and taxonomy. Intervirology 16:201-217 (1981).

Ross, L.J.N.; Milne, B.; Biggs, P.M.: Restriction endonuclease analysis of Marek's disease virus DNA and homology between strains. J. gen. Virol. 64: 2785-2790 (1983). 
Morphology

Reported by C.R. Howard

\section{Properties of the Virus Particle}

Overall spherical particles, $40-48 \mathrm{~nm}$ in diameter with no surface projections. Outer $7 \mathrm{~nm}$ detergent-sensitive envelope surrounds an icosahedral nucleocapsid with 180 capsomeres arranged with $\mathrm{T}=3$ symmetry, made up of one major polypeptide species. The virion envelope is antigenically similar to the nucleic acid-free $22 \mathrm{~nm}$ lipoprotein particles (HBsAg) that occur naturally in the sera of infected patients.

\section{Physicochemical} properties

Nucleic acid
$S_{20 \mathrm{w}} \approx 280$; buoyant density in $\mathrm{CsCl}=1.24-1.26 \mathrm{~g} / \mathrm{cm}^{3}$, (surface antigen particles without core $=1.18 \mathrm{~g} / \mathrm{cm}^{3}$ ). Unstable in acid $\mathrm{pH}$; infectivity retained for 6 months at $30-32^{\circ} \mathrm{C}$ or $10 \mathrm{~h}$ at $60^{\circ} \mathrm{C}$.

Single, circular molecule of partially ds and partially ssDNA; $\mathrm{MW} \approx 1.6 \times 10^{6} ; \mathrm{S}_{20 \mathrm{w}} \approx 15 \mathrm{~S} ; \mathrm{G}+\mathrm{C} \approx 48 \%$. One strand (negative sense, complementary to mRNA) is full length (3.02-3.32 kb) and the other varies in length from 1.7 to $2.8 \mathrm{~kb}$. Length of cloned DNA (fully doublestranded) $\approx 3.2 \mathrm{kbp}$.

The full length strand (negative strand) has a nick at a unique site $242 \mathrm{bp}$ (or ca. $50 \mathrm{bp}$ for Avihepadnavirus) from the $5^{\prime}$ end of the short positive strand. Neither strand is a covalently closed circle. The uniquely located 5 '-ends of the two strands overlap by approximately 240 bp so that the circular configuration of the DNA is maintained by base pairing of cohesive ends. The $5^{\prime}$ end of the full-length DNA strand has a covalently attached terminal protein. Virion core contains a DNA polymerase which uses the 3' end of the short DNA strand as a primer and repairs ss regions to make full-length $(3.2 \mathrm{kbp}) \mathrm{ds}$ molecules.

Genome DNA has four ORF's, all orientated in the same direction on the long (minus) DNA strand. One ORF (the S-gene) specifies the major (MW $\approx 24 \times 10^{3}$ ) hepatitis $B$ surface antigen ( $\mathrm{HBsAg})$ polypeptide and is preceded by a 'pre-S region' with two in-frame start codons (ATG) which are sites for initiation of the minor HBsAg polypeptides $\left(\mathrm{MW} \approx 33 \times 10^{3}, 36 \times 10^{3}, 39 \times 10^{3}\right.$ and 42 $\mathrm{x} 10^{3}$ ). A second ORF (the C-gene) specifies the major $\left(\mathrm{MW} \approx 22 \times 10^{3}\right)$ hepatitis $\mathrm{B}$ core antigen $(\mathrm{HBcAg})$ 
polypeptide and is preceded by a short 'pre-C region' which can specify 29 amino acids. The longest ORF (the P-gene) covers $80 \%$ of the genome and overlaps the other three ORF's. It codes for the terminal protein, a reverse transcriptase, the viral DNA polymerase and an RNAse $\mathrm{H}$. The fourth ORF, designated the X-gene, has been shown to possess transactivation properties in in vitro transfection experiments but its role in natural infection is unknown.

Protein

Lipid

The virion coat is composed of following virus-coded proteins: S-proteins (P24, GP27), M-proteins (GP33, GP36), L-proteins (P39, GP42). The virion core is composed of one major protein, $\mathrm{MW} \approx 22 \times 10^{3}$.

$\mathrm{HBsAg}$ particles composed of virion envelope material consist largely of S-proteins. The two major $\mathrm{S}$ polypeptides have $\mathrm{MW}=24 \times 10^{3}$ (GP24) and $27 \times 10^{3}$ (GP27). They appear to have the same amino acid composition except that GP27 is glycosylated; The Mproteins GP33 and GP36 are composed of P24 with an additional 55 amino acids at the $\mathrm{N}$-terminus, differ in the extent of glycosylation and bear the pre-S2 domain. The L-proteins P39 and GP42 contain a further ca. 120 amino acids, differ in glycosylation and bear the pre-S1 domain.

Enzymes: protein kinase, RNA- and DNA-dependant polymerase and RNase $\mathrm{H}$. Other functional proteins: Terminal protein covalently attached to the 5'-end of the full-length DNA strand which may act as a primase.

Demonstrated in $22 \mathrm{~nm}$ HBsAg particles and virions probably derived from the ER. The $\mathrm{N}$-terminus of the Lproteins is myristoylated.

Carbohydrate Demonstrated in $22 \mathrm{~nm} \mathrm{HBsAg}$ particles and virions as Nlinked glycans.

Antigenic properties

$\mathrm{HBsAg}, \mathrm{HBcAg}, \mathrm{HBeAg}$ antigens. $\mathrm{HBeAg}$ and $\mathrm{HBcAg}$ proteins share common epitopes but also contain epitopes which distinguish these two proteins from each other. Antigens involved in neutralization: $\mathrm{HBsAg}, \mathrm{HBsAg}$ cross-reacts to a limited extent with the analogous antigens of woodchuck and ground squirrel viruses. No crossreaction exists between HBsAg and the analogous antigen of DHBV. 'Pre-S region' may bear specific neutralization determinants. $S$ proteins are sufficient to stimulate protective immunity.

$\mathrm{HBcAg}$ has been found to cross-react more strongly with the woodchuck virus core antigen than did the corresponding surface antigens. 
Antigenic properties used for identification: At least 5 antigenic specificities may be found on HBsAg particles. A group determinant (a) is shared by all HBsAg preparations, and 2 pairs of subtype determinants (d, y and $\mathrm{w}, \mathrm{r}$ ) which are, for the most part, mutually exclusive and thus usually behave as alleles, have been demonstrated. Antigenic heterogeneity of the w determinants and additional determinants, such as $\mathrm{q}$ and $\mathrm{x}$ or $\mathrm{g}$, have also been described. To date, $8 \mathrm{HBsAg}$ subtypes have been identified, namely ayw, ayw 2 , ayw3, ayw4, ayr, adw2, adw4 and adr. Unusual combinations of HBsAg subtype determinants such as awr, adwr, adyw, adyr and adywr, have been reported. The distribution of HBsAg subtypes occurs in uneven geographical distribution. The subtype specificity of HBsAg can be affected by mutations.

\section{REPLICATION}

Transcription: At least two major RNA transcripts are found in $\mathrm{HBV}$-infected human liver. The two unspliced transcripts have different 5 '-ends (both capped) and colinear 3'-ends (both polyadenylated) ending within the core protein gene. The shortest transcript $(2.3 \mathrm{~kb})$ is initiated in the middle of the pre-S region, and the greater than genome length longer transcript $(3.4 \mathrm{~kb})$ is initiated near the core gene start codon. The $2.3 \mathrm{~kb}$ transcript appears to be found in cells expressing HBsAg only, and both appear in cells supporting virus replication.

DNA replication: Current evidence indicates that virus replication involves the generation of a covalently closed circular DNA molecule followed by synthesis of a greater than genome length $(\approx 3.4 \mathrm{~kb})$ plus strand RNA which is packaged in viral core particles and serves as a template for synthesis of the minus DNA strand (reverse transcription) using a protein primer. The minus DNA strand serves as template for plus DNA strand synthesis and is primed by transposition of the 5'-end of the plus strand RNA remaining after $\mathrm{RNase} H$ digestion from direct repeat 1 (DR1) to DR2. The plus DNA strand is incomplete in most core particles at the time of virion assembly and is released from the cell. Partially ssDNA of hepatitis $B$ virus with properties of a replicative intermediate, has been detected in hepatocyte cytoplasm and similar material in $\mathrm{HBV}$-infected liver extracts has been identified as negative sense ss DNA. 
Site of maturation of full and empty hepatitis B virion cores appears to be in the nuclei and cytoplasm of infected hepatocytes, but no reliable information is available on the exact mechanism of hepadnavirus maturation. HBsAg has only been detected in cell cytoplasm and cytoplasmic membranes but $\mathrm{HBcAg}$ has been detected in both cytoplasm and nucleus (hepatitis $B$ virus only). Integration is not required for replication.

\section{Biological ASPECtS}

Host range

Transmission

The hepadnaviruses are exquisitely host specific. For example, the only known natural hosts of hepatitis B virus are humans, but chimpanzees and gibbons may be infected experimentally. Transmission of hepatitis B virus has also been reported in African monkeys, rhesus and wooly monkeys. Hepadnaviruses may cause acute and chronic hepatitis, cirrhosis, hepatocellular carcinoma, immune complex disease, polyarteritis, glomerulonephritis, infantile papular acrodermatitis and aplasmic anaemia. In vitro, hepatitis B virus, ground squirrel hepatitis B virus and woodchuck hepatitis $B$ virus replication with production of infectious virus, has been demonstrated following transfection of tissue culture cells with cloned DNA. Replication of several hepadnaviruses has been achieved following inoculation of primary hepatocytes with serum containing virus.

Vertical transmission has been clearly demonstrated in ducks and may occur in humans. Horizontal transmission can be by perinatal percutaneous, sexual and other routes of close contact, e.g. intravenous drug abuse, and by use of infected blood and blood products. Hepadnaviruses can survive on surfaces which may contact mucous membranes or open skin breaks, such as toothbrushes, baby bottles, toys, eating utensils, razors or hospital equipment such as respirators, endoscopes or laboratory equipment.

Although some populations of mosquitoes and bedbugs caught in Africa and the United States have been shown to contain HBsAg, there has been no direct demonstration of transmission to man by insect vectors.

\section{GENERA}

Hepatitis B virus group Duck hepatitis B virus group

Orthohepadnavirus Avihepadnavirus 


\begin{tabular}{llc}
\hline \hline GENUS & HEPATITIS B & ORTHOHEPADNAVIRUS \\
& VIRUS GROUP & - \\
\hline TYPE SPECIES & HEPATITIS B & \\
& VIRUS (HBV) & \\
\hline
\end{tabular}

Properties of The Viral Particle

Spherical particles 40-42 $\mathrm{nm}$ diameter, internal nucleocapsid $27 \mathrm{~nm}$ diameter. Virion coat consists of $\mathrm{L}$, $\mathrm{M}$ and $\mathrm{S}$ proteins.

\section{BIOLOGICAL ASPECTS}

Clinical manifestations include acute and chronic liver disease. Associated with the development of hepatocellular carcinoma.

\section{OTHER MEMBERS}

Woodchuck hepatitis B virus

Ground squirrel hepatitis B virus

\begin{tabular}{llc}
\hline \hline GENUS & $\begin{array}{l}\text { DUCK HEPATITIS } \\
\text { GROUP }\end{array}$ & AVIHEPADNAVIRUS \\
\hline TYPE SPECIES & $\begin{array}{l}\text { DUCK HEPATITIS B } \\
\text { VIRUS (DHBV) }\end{array}$ & - \\
\hline
\end{tabular}

Properties of the Virus Particle

Spherical particle $46-48 \mathrm{~nm}$ diameter, internal nucleocapsid $35 \mathrm{~nm}$ diameter.

Plus strand DNA nearly full length.

Do not contain a separate $\mathrm{X}$ ORF. Virion coat possesses $\mathrm{L}$ protein, $\mathrm{MW} \approx 36 \times 10^{3}$ and $\mathrm{S}$ protein $\mathrm{MW} \approx 17 \times 10^{3}$. There is no M protein.

\section{Biological Aspects}

Clinical manifestations are rare.

Transmission is predominantly vertical.

\section{OTHER MEMBERS}

Heron hepatitis B virus (HHBV). 
Derivation

hepa: from hepatotropism

of Name

dna: from DNA (= the sigla for deoxyribonucleic acid)

ortho: from Greek orthos, 'straight, correct'

avi: from Latin avis, 'bird'.

\section{REFERENCES}

Galibert, F.; Mandart, E.; Fitoussi, F.; Tiollais, P.; Charnay, P.: Nucleotide sequence of the hepatitis B virus genome (subtype ayw) cloned in E. coli. Nature 281:646-650 (1979).

Ganem, D.; Varmus, H.E.: The molecular biology of the hepatitis B viruses. Ann. Rev. Biochem. 56: 651-693 (1987).

Howard, C.R.: The biology of hepadnaviruses. J. gen. Virol. 67: 1215-1235 (1986).

Marion, P.L.; Robinson, W.S.: Hepadnaviruses: Hepatitis B and related viruses. Curr. Top. Microbiol. Immunol. 105:99-121 (1983).

Schödel, F.; Sprengel, R.; Weimer, T.; Fernholz, D.; Schneider, R.; Will, H.: Animal hepatitis B viruses. Adv. Viral. Oncol. 8: 73-102 (1989).

Summers, J.; Mason, W.S.: Replication of the genome of a hepatitis B-like virus by reverse transcription of an RNA intermediate. Cell 29: 403-415 (1982).

Tiollais, P.; Pourcel, C.; Dejean, A.: The hepatitis B virus. Nature 317: 489-495 (1985). 


\begin{tabular}{|ll}
\hline FAMILY & BACULOVIRUSES \\
\hline
\end{tabular}

Reported by M. Wilson

Morphology

\section{Properties of The Virus Particle}

Virions consist of one or more rod-shaped electron-dense nucleocapsids enclosed within a single envelope. The nucleocapsids average $30-60 \mathrm{~nm}$ in diameter and $250-300$ $\mathrm{nm}$ in length within the subfamily Eubaculovirinae. The size of enveloped nucleocapsids within this subfamily is more variable. Virions of members of the subfamily Nudibaculovirinae are of one or other of two types. The virions of Oryctes rhinoceros virus contain a long and narrow tail-like projection $(10 \times 270 \mathrm{~nm})$ attached to one end of the nucleocapsid which is approximately $100 \times 200$ $\mathrm{nm}$ in size. The Heliothis zea nonoccluded virions are morphologically similar to those of the occluded baculoviruses but are approximately twice the size, measuring $80 \times 414 \mathrm{~nm}$.

Physicochemical properties

Nucleic acid

Protein

\section{Lipid}

Carbohydrate

Antigenic properties
Density of nucleocapsid in $\mathrm{CsCl} \approx 1.47 \mathrm{~g} / \mathrm{cm}^{3}$ and of the virion, $1.18-1.25 \mathrm{~g} / \mathrm{cm}^{3}$. Ether and heat labile.

Single molecule of circular supercoiled dsDNA; MW 90$230 \mathrm{~kb} ; 8-15 \%$ of particle weight. $\mathrm{G}+\mathrm{C}$ content is variable from $28-59 \%$.

Virions are structurally complex and contain at least $12-30$ structural polypeptides; Alkaline proteases associated with occlusions isolated from infected insects. The major protein of the viral inclusion (where present) is a single polypeptide, viral encoded, with MW $=25-33 \times 10^{3}$. This protein called polyhedrin for nuclear polyhedrosis viruses and granulin for granulosis viruses. Virions contain protein kinase activity.

Present but not characterized.

Present but not characterized.

Antigenic determinants that cross react exist on the virion structural proteins and on the major subunit of polyhedrin and granulin polypeptides.

\section{REPLICATION}

Nuclear polyhedrosis viruses and non-occluded baculoviruses replicate exclusively in the nucleus. 
Members of the granulosis virus genus also replicate mostly within the nucleus, but replication can occur in the cytoplasm. During infection, two forms of virions are produced. Early in infection, single nucleocapsids bud through the plasma membrane and this form of the virion is referred to as the extracellular virion (ECV). The occluded virions appear later in the infection cycle as enveloped virions embedded within a viral inclusion. The occluded form of the virus is important in the horizontal transmission of the virus. Members of the nonoccluded baculovirus subfamily do not produce inclusion bodies. For all genera, cell to cell spread is presumably by extracellular virions.

\section{Biological ASPECTS}

Baculoviruses have been isolated from Arthropoda: Insecta, Arachnida and Crustacea. Transmission: (i) natural - horizontal, by contamination of food, etc.; (ii) vertical on the egg; (iii) experimental - by injection of insects or by infection or transfection of cell cultures.

\section{SUBFAMILIES}

Occluded baculoviruses Eubaculovirinae

Nonoccluded baculoviruses Nudibaculovirinae

\begin{tabular}{ll}
\hline SUBFAMILY & - \\
\hline PROPERTIES OF THE VIRUS PARTICLE \\
Virions are either occluded in a crystalline protein viral \\
occlusion which may be polyhedral in shape and contain \\
one or many virions (genus NPV) or the inclusions are \\
ovicylindrical and contain only one or rarely two virions \\
(genus GV).
\end{tabular}

\section{GENERA}

Nuclear polyhedrosis virus (NPV)

Granulosis virus (GV)

\begin{tabular}{lll}
\hline \hline GENUS & NUCLEAR POLYHEDROSIS & - \\
& VIRUS (NPV) & \\
\hline
\end{tabular}

\section{SUBGENERA}

Multiple nucleocapsids per envelope (MNPV)

Single nucleocapsid per envelope (SNPV) 


\begin{tabular}{llc} 
Taxonomic status & English vernacular name & International name \\
\hline \hline SUBGENUS & MULTIPLE NUCLEOCAPSID & - \\
& VIRUSES (MNPV) & \\
\hline TYPE SPECIES & AUTOGRAPHA CALIFORNICA & - \\
& NUCLEAR POLYHEDROSIS & \\
& VIRUS (ACMNPV) & \\
\hline
\end{tabular}

\section{Properties of the Virus Particle}

Autographa californica nuclear polyhedrosis virus (AcMNPV) is representative of subgenus MNPV, where the virions may contain one to many or multiple (M) nucleocapsids within a single viral envelope (MNPV). All species have many virions embedded in a single viral occlusion or polyhedron. The inclusion-specific protein is referred to as polyhedrin and enveloped nucleocapsids released from polyhedra are referred to as polyhedralderived virus (PDV). Virions that have not been occluded and released naturally from infected cells are referred to as extracellular virus (ECV).

\section{OTHER MEMBERS}

Choristoneura fumiferana MNPV (CfMNPV)

Mamestra brassicae MNPV (MbMNPV)

Orgyia pseudotsugata MNPV (OpMNPV)

and approximately 400-500 species isolated from seven insect orders and from Crustacea.

\begin{tabular}{lll}
\hline \hline SUBGENUS & SINGLE NUCLEOCAPSID & - \\
& VIRUSES (SNPV) & - \\
\hline TYPE SPECIES & BOMBYX MORI S & \\
& NUCLEAR POLYHEDROSIS & \\
& VIRUS (BMSNPV) & \\
\hline
\end{tabular}

\section{Properties of The Virus Particle}

Enveloped single (S) nucleocapsids with many virions embedded per viral inclusion.

\section{OTHER MEMBERS}

Heliothis zea SNPV (HzSnpv)

Trichoplusia ni SNPV (TnSnpv)

and similar viruses isolated from seven insect orders and from Crustacea. 


\begin{tabular}{lll}
\hline \hline GENUS & GRANULOSIS VIRUSES (GV) & - \\
\hline TYPE SPECIES & PLODIA INTERPUNCTELLA & - \\
& GRANULOSIS VIRUS (PIGV) & \\
\hline
\end{tabular}

\section{Properties of the Virus Particle}

Enveloped single nucleocapsid with one virion per viral occlusion or granule. Granulin, the major granule or viral occlusion protein is similar in function to that of polyhedrin. Virions released from the granule are referred to as granule-derived virus (GDV). Virions that are not occluded are referred to as extracellular virions (ECV).

\section{OTHER MEMBERS}

Trichoplusia ni granulosis virus (TnGV)

Pieris brassicae granulosis virus (PbGV)

Artogeia rapae granulosis virus (ArGV)

Cydia pomonella granulosis virus (CpGV)

and similar viruses from about 50 species in the Lepidoptera

\begin{tabular}{lll}
\hline \hline SUBFAMILY & $\begin{array}{l}\text { NON-OCCLUDED } \\
\text { BACULOVIRUSES }\end{array}$ & NUDIBACULOVIRINAE \\
\hline
\end{tabular}

\section{Properties of the Virus Particle}

Enveloped single nucleocapsids. No viral occlusions are produced. Establishes persistent infections with all known host cells. Wide host range among lepidopteran cell cultures. "Standards" and defective populations can be isolated. The standard $\mathrm{Hz}-1$ genome is $228 \mathrm{~kb}$. The virus particle is bacilliform, measuring $414 \pm 30 \times 80 \pm 3$ $\mathrm{nm}$. There are approximately 28 structural proteins ranging in molecular weight from 153,000 to 14,000 . Fourteen of these are glycoproteins. The defective particles are heterogenous in length $(370 \pm 76 \mathrm{~nm})$ and contain genomic deletions up to $100 \mathrm{~kb}$. Defective virus particles contain the same structural proteins detected in standard virus particles. 


\begin{tabular}{llc} 
Taxonomic status & English vemacular name & International name \\
\hline \hline GENUS & NON-OCCLUDED & - \\
& BACULOVIRUSES (NOB) & \\
\hline TYPE SPECIES & HELIOTHIS ZEA NOB (HZNOB) & - \\
\hline
\end{tabular}

Properties of the Virus Particle

Enveloped single nucleocapsids. No viral occlusions produced.

OTHER MEMBERS

Oryctes rhinoceros virus

\section{Possible members of the family Baculoviridae}

A diverse group based upon morphological variation of virus structure which requires further delineation into distinct subgroups as more data become available. These are virus particles with similar general structure to baculoviruses isolated from mites, Crustacea and Coleoptera. Putative baculoviruses have been observed in a fungus (Strongwellsea magna), a spider, the European crab (Carcinus maenas), and the blue crab (Callinectes sapidus).

Derivation of Name baculo from Latin baculum, 'stick', from morphology of virion.

eu from Greek eu, 'good, well, correct'. nudi from Latin nudus, 'nude'.

\section{REFERENCES}

Arif, B.A.; Kuzio, J.; Faulkner, P.; Doerfler, W.: The genome of Choristoneura fumiferans nuclear polyhedrosis virus: Molecular cloning and mapping of the EcoRI, BamHI, SmaI, $\mathrm{XbaI}$ and BglII restriction sites. Virus Res. 1:605-614 (1984).

Arnott, H.J.; Smith, K.M.: An ultrastructural study of the development of a granulosis virus in the cells of the moth Plodia interpunctella (Hbn.). J. Ultrastruct. Res. 21:251-268 (1968).

Carstens, E.B.; Tjia, S.T.; Doerfler, W.: Infection of Spodoptera frugiperda cells with Autographa californica nuclear polyhedrosis virus. Virology 99:386-398 (1979).

Carstens, E.B.; Tjia, S.T.; Doerfler, W.: Infectious DNA from Autographa californica nuclear polyhedrosis virus. Virology 101:311-314 (1980).

Chakerian, R.; Rohrmann, G.F.; Nesson, M.H.; Leisy, D.J.; Beaudreau, G.S.: The nucleotide sequence of the Pieris brassicae granulosis virus granulin gene. J. gen. Virol. 66:12631269 (1985). 
Consigli, R.A.; Russell, D.L.; Wilson, M.E.: The biochemistry and molecular biology of the granulosis virus that infects Plodia interpunctella. Cur. Topics Microbiol. Immunol. 131:69-101 (1986).

Couch, J.A.: An enzootic nuclear polyhedrosis virus of pink shrimp: ultrastructure, prevalence, and enhancement. J. Invertebr. Pathol. 24:311-331 (1974).

Couch, J.A.: Viral diseases of invertebrates other than insects. In Davidson, D. (ed.), Pathogenesis of Invertebrate Microbial Diseases (Osmun Publishers, Allenheld, 1981).

Couch, J.A.: Inclusion body viruses. Baculoviruses of Invertebrates other than Insects. (CRC Press, Boca Raton, Fl.) (in press).

Crook, N.E.; Spencer, R.A.; Payne, C.C.; Leisy, D.J.: Variation in Cydia pomonella granulosis virus isolates and physical maps of the DNA from three variants. J. gen. Virol. 66:2423-2430 (1985).

Doerfler, W.; Bohm, P.: The molecular Biology of Baculoviruses. Cur. Topics Microbiol. Immunol. 131:1-168 (1986).

Granados, R.R.; Federici, B.A.: The Biology of Baculoviruses. (CRC Press, Boca Raton, Fl., 1986)

Granados, R.R.; Lawler, K.A.: In vivo pathway of Autographa californica baculovirus invasion and infection. Virology 108:297-308 (1981).

Harrap, K.A.: The structure of nuclear polyhedrosis viruses. III. Virus assembly. Virology 50:133-139 (1972).

Harrap, K.A.; Payne, C.C.: The structural properties and identification of insect viruses. Adv. Virus Res. 25:273-355 (1979).

Hohmann, A.W.; Faulkner, P.: Monoclonal antibodies to baculovirus structural proteins: determination of specificities by Western Blot Analysis. Virology 125:432-444 (1983).

Hull, R.; Brown, F.; Payne, C.C.: Dictionary and Directory of Animal, Plant and Bacterial Viruses. (Macmillans, London, 1989).

Krell, J.D.; Summers, M.D.: A physical map for the Heliothis zea SNPV genome. J. gen. Virol. 65:445-450 (1984).

Maruniak, J.E.; Summers, M.D.: Comparative peptide mapping of baculovirus polyhedrins. J. Invertebr. Pathol. 32:196-201 (1978).

Miller, L.K.; Adang, M.J.; Browne, D.: Protein kinase activity associated with the extracellular and occluded forms of the baculovirus Autographa californica nuclear polyhedrosis virus. J. Virol. 46:275-278 (1983).

Payne, C.C.: The isolation and characterization of a virus from Oryctes rhinoceros. J. gen. Virol. 25:105-116 (1974).

Payne, C.C.; Kalmakoff, J.: Alkaline protease associated with virus particles of a nuclear polyhedrosis virus: assay, purification and properties. J. gen. Virol. 26: 84-92 (1978).

Smith, G.E.; Summers, M.D.: DNA homology among subgroup A, B, and C baculoviruses. Virology 123:393-406 (1982).

Smith, G.E.; Summers, M.D.: Restriction maps of five Autographa californica MNPV variants, Trichoplusia ni MNPV, and Galleria mellonella MNPV DNAs with endonucleases SmaI, KpnI, BamHI, SacI, XhoI, and EcoRI. J. Virol. 30:828-838 (1979).

Smith, I.R.L.; Crook, N.E.: Physical maps of the genome of four variants of Artogeia rapae granulosis virus. J. gen. Virol. 69: 1741-1747 (1988).

Summers, M.D.; Hoops, P.: Radioimmunoassay analysis of baculovirus granulins and polyhedrins. Virology 103:89-98 (1980).

Summers, M.D.; Smith, G.E.; Krell, J.D.; Burand, J.P.: Physical maps of Autographa californica and Rachiplusia ou nuclear polyhedrosis virus recombinants. J. Virol. 34: 693-703 (1980).

Tweeten, K.A.; Bulla, L.A.Jr.; Consigli, R.A.: Characterization of an extremely basic protein derived from granulosis virus nucleocapsids. J. Virol. 33: 866-876 (1980a).

Tweeten, K.A.; Bulla, L.A.Jr.; Consigli, R.A.: Structural polypeptides of the granulosis virus of Plodia interpunctella . J. Virol. 33: 877-886 (1980b).

Vlak, J.M.; Odink, K.G.: Characterization of Autographa californica nuclear polyhedrosis virus deoxyribonucleic acids. J. gen. Virol. 44: 333-347 (1979). 
Vlak, J.M.; Smith, G.E.: Orientation of the genome of Autographa californica nuclear polyhedrosis virus: a proposal. J. Virol. 41:1118-1121 (1982).

Volkman, L.E.; Summers, M.D.; Hsieh, C.H.: Occluded and nonoccluded nuclear polyhedrosis virus grown in Trichoplosia ni: Comparative neutralization, comparative infectivity and in vitro growth studies. J. Virol. 19:820-832 (1976).

Wiegers, F.P.; Vlak, J.M.: Physical map of the DNA of a Mamestra brassicae nuclear polyhedrosis virus variant isolated from Spodoptera exigua. J. gen. Virol. 65: 20112019 (1984).

Wilson, M.E.; Consigli, R.A.: Characterization of a protein kinase activity associated with purified capsids of the granulosis virus infecting Plodia interpunctella. Virology 143:516-525 (1985).

Wood, H.A.: Autographa californica nuclear polyhedrosis virus-induced proteins in tissue culture. Virology 102:21-27 (1980).

Wood, H.A.; Burand, J.P.: Persistent and productive infections with the Hz-1 baculovirus. Cur. Topics Microbiol. Immunol. 131:119-133 (1985). 
Revised by H.-W. Ackermann \& J. Maniloff

\begin{tabular}{llc}
\hline \hline GENUS & PLEOMORPHIC PHAGES & PLASMAVIRUS \\
\hline TYPE SPECIES & ACHOLEPLASMA PHAGE & - \\
& L2 GROUP \\
\hline
\end{tabular}

Morphology

\section{Properties of the Virus Particle}

Quasi-spherical, slightly pleomorphic, with envelope, about 80 (range 50-125) $\mathrm{nm}$ in diameter. Size range is due to virion heterogeneity; at least three distinct virion forms are produced during infection. Sections show a small, dense core inside the envelope.

Physicochemical Infectivity is ether-, chloroform-, detergent-, and heatproperties sensitive.

Nucleic acid One molecule of circular supercoiled dsDNA; $\mathrm{MW} \approx 7.6$ x $10^{6}, 11970 \mathrm{kbp} ; \mathrm{G}+\mathrm{C}=32 \%$.

Protein

Lipid

Carbohydrate Not known.

\section{REPLICATION}

Has both nonlytic cytocidal producing infectious cycle and lysogenic cycle. Noncytocidal infection; progeny virus released by budding from host cell membrane, with host surviving as lysogen. Lysogeny involves integration into unique site in host cell chromosome.

\section{Biological Aspects}

Host range: Acholeplasma.

\section{OTHER MEMBERS}

\section{7}

\section{Possible members}

v1, v2, v4, v5, v7 
Derivation of plasma: from Greek plasma, 'shaped product'

Name

\section{REFERENCES}

Ackermann, H.-W.; DuBow, M.S.: Viruses of Prokaryotes, Vol. II, pp. 171-218 (CRC Press, Boca Raton, Fl., 1987).

Maniloff, J.: Mycoplasma viruses. CRC Crit. Rev. Microbiol. 15: 339-389 (1988). 


\begin{tabular}{|lll}
\hline FAMILY & SSV1-TYPE PHAGES & - \\
\hline
\end{tabular}

Compiled by H.-W. Ackermann \& W. Zillig

\begin{tabular}{lll}
\hline \hline GENUS & SSV1 GROUP & - \\
\hline TYPE SPECIES & SULFOLOBUS PARTICLE SSV1 & - \\
\hline
\end{tabular}

\section{Properties of The Virus Particle}

Morphology Lemon-shaped, slightly flexible particles of $60 \times 100 \mathrm{~nm}$; short spikes at one end.

Physicochemical Structure is resistant to high temperatures, acid $\mathrm{pH}$, urea properties and ether. It is sensitive to basic $\mathrm{pH}$ and chloroform.

Nucleic acid One molecule of circular, positively supercoiled dsDNA of $\approx 15 \mathrm{kbp}(15,463 \mathrm{bp})$, associated with polyamines and a virus-coded basic protein.

Protein

Two hydrophobic coat proteins, MW $=7.7$ and $9.7 \times 10^{3}$, one DNA-associated protein. Major coat protein is ethersoluble.

Lipid None.

Carbohydrate Not known.

\section{REPLICATION}

Genome is present in cells as a plasmid or integrated into specific sites. UV induction results in large numbers of particles which are released without lysis.

\section{Biological aspects}

Host range Sulfolobus shibatae strain B12.

\section{Possible members}

Particles produced by the archaebacteria Desulfurolobus and Methanococcus.

\section{REFERENCES}

Zillig, W.; Reiter, W.-D.; Palm, P.; Gropp, F.; Neumann, H.; Rettenberger, M.: Viruses of archaebacteria. In Calendar. R. (ed.), The Bacteriophages, Vol. 1, pp. 517-558 (Plenum Press, New York, 1988). 


\begin{tabular}{|lll}
\hline FAMILY TTV1 FAMILY LIPOTHRIXVIRIDAE \\
\hline
\end{tabular}

Compiled by H.-W. Ackermann \& W. Zillig

\begin{tabular}{llc}
\hline \hline GENUS & TTV1 GROUP & LIPOTHRIXVIRUS \\
\hline TYPE SPECIES & THERMOPROTEUS & - \\
& PHAGE TTV1 & \\
\hline
\end{tabular}

\section{Properties of The Virus Particle}

Morphology Thick rigid rods about $400 \mathrm{~nm}$ long x $40 \mathrm{~nm}$ in diameter. Both ends have protrusions which seem to participate in adsorption. Envelope.

Physicochemical Ether and detergents cause disruption of particles. properties

Nucleic acid One molecule of linear dsDNA; MW $\approx 10 \times 10^{6}(16 \mathrm{kbp})$.

Protein Four proteins (MW 14-45 x 103). P1 and P2 are DNAassociated, $\mathrm{P} 3$ is the envelope protein. The location of P4 is unknown.

Lipid In addition to $\mathrm{P} 3$ protein, the envelope contains lipids in the same proportions as the host membranes. Bilayer structure.

Carbohydrate Glucose in glycolipid.

\section{REPLICATION}

Adsorption to pili? Infection results in virus production with lysis or the establishment of a carrier state. Pieces of TTV1 DNA may be integrated into the host genome.

\section{Biological ASPECTS}

Host range Host range is limited to the archaebacterium Thermoproteus tenax. Other rod-shaped particles of different dimensions were found associated with Thermoproteus cultures or were observed by electron microscopy in water from Icelandic solfataras but were not cultivated. One of these particles, TTV2, is temperate.

\section{Derivation of} Name lipo: from Greek, lipos, 'fat' thrix: from Greek, thrix, 'hair' 


\section{REFERENCES}

Zillig, W.; Reiter, W.-D.; Palm, P.; Gropp, F.; Neumann, H.; Rettenberger, M.: Viruses of archaebacteria. In Calendar, R. (ed.), The Bacteriophages, Vol. 1, pp. 517-558 (Plenum, Press, New York, 1988). 
Morphology

Nucleic acid

Protein

Lipid

Carbohydrate

Antigenic properties

\section{Properties of The Virus Particle}

Ichnovirus particles consist of nucleocapsids of usually uniform size (approximately $85 \mathrm{~nm} \times 330 \mathrm{~nm}$ ), having the form of a prolate ellipsoid, and surrounded by 2 unit membrane envelopes. The inner envelope appears to be assembled de novo within the nucleus of infected calyx cells and the outermost envelope is acquired by budding through the plasma membrane into the oviduct lumen. Bracovirus particles consist of enveloped cylindrical electron-dense nucleocapsids of uniform diameter but of variable length ( $40 \mathrm{~nm}$ diameter by $30-150 \mathrm{~nm}$ length) and may contain one or more nucleocapsids within a single viral envelope; the latter appears to be assembled de novo within the nucleus.

Genomes consist of multiple supercoiled double-stranded DNAs of variable MWs ranging from approximately 2.0 to more than $28 \mathrm{kbp}$. No aggregated MW for any polydnavirus genome has as yet been determined with any degree of accuracy. Estimates of genome complexity are complicated by the presence of related DNA sequences shared among the multiple DNAs.

Virions are structurally complex and contain at least 20-30 polypeptides, with MWs ranging from 10-200 x $10^{3}$.

Present, but uncharacterized.

Present, but uncharacterized.

Cross-reacting antigenic determinants exist on ichnoviruses within each genus; in some cases, viral nucleocapsids share at least one major conserved epitope. Antigenic relationships among the bracoviruses have not as yet been investigated.

\section{REPLICATION}

Viruses replicate in the nucleus. Replication occurs in the calyx epithelium of the ovaries of all female wasps belonging to any species. Ichnoviruses bud directly from the calyx epithelial cells into the lumen of the oviduct. The mode of release of bracovirus particles is presently 
unclear, but may involve lysis of infected calyx epithelial cells. Viral DNAs are present in male wasps, but replication has not been demonstrated.

\section{BIOLOGICAL ASPECTS}

Host range Polydnaviruses have been isolated only from endoparasitic hymenopteran insects belonging to the families Ichneumonidae and Braconidae.

Transmission. The mechanism of transmission appears to be vertical within parasitoid species. Viruses are injected into larval hosts during oviposition, but replication in parasitized host insects or in cultured cells has not been observed.

\begin{tabular}{llc}
\hline \hline GENUS & - & ICHNOVIRUS \\
\hline TYPE SPECIES & $\begin{array}{l}\text { CAMPOLETIS SONORENSIS } \\
\text { VIRUS (CSV) }\end{array}$ & - \\
\hline
\end{tabular}

\section{Properties of The Virus Particle}

One nucleocapsid having the form of a prolate ellipsoid $(85 \times 330 \mathrm{~nm})$, per virion; two envelopes; segmented DNA genome.

\section{OTHER MEMBERS}

A similar virus has been found in Glypta sp., but these particles differ in having more than one nucleocapsid per virion. Polydnaviruses having a morphology resembling that of $\mathrm{CsV}$ are typically but perhaps not exclusively found in ichneumonids belonging to the sub-family Campopleginae.

\begin{tabular}{llc}
\hline \hline GENUS & \multicolumn{1}{c}{-} & BRACOVIRUS \\
\hline TYPE SPECIES & COTESIA MELANOSCELA & - \\
& VIRUS (CMV) & \\
\hline
\end{tabular}

Properties of the Virus Particle

Nucleocapsids are cylindrical with a uniform diameter (40 $\mathrm{nm}$ ) but variable in length $(30-150 \mathrm{~nm})$. Virions have only one envelope which may surround one or more nucleocapsids; segmented DNA genome. 


Derivation of polydna: from poly, 'several', DNA virus
Name

\section{RFFERENCES}

Blissard, G.W'; Smith, O.P.; Summers, M.D.: Two related viral genes are located on a single supcrhclical DNA segment of the multipartite Campoletis sonorensis virus genome. Virology 160: 120-134 (1987).

Blissard, G.W.; Fleming, J.G.W.; Vinson, S.B.; Summers, M.D.: Campoletis sonorensis virus: expression in Heliothis virescens and identification of expressed sequences. J. Insect Physiol. 32: 351-359 (1986).

Cook, D.; Stoltz, D.B.: Comparative serology of viruses isolated from ichneumonid parasitoids. Virology 130:215-220 (1983).

Edson, K.M.; Vinson, S.B.; Stoltz, D.B.; Summers, M.D.: Virus in a parasitoid wasp: suppression of the cellular immune response in the parasitoid's host. Science 211:582583 (1981).

Fleming, J.G.W.; Summers, M.D.: Campoletis sonorensis endoparasitic wasps contain forms of $C$. sonorensis virus DNA suggestive of integrated and extrachromosomal polydnavirus DNAs. J. Virol. 57:552-562 (1986).

Fleming, J.G.W.; Blissard, G.W.; Summers, M.D.; Vinson, S.B.: Expression of Campoletis sonorensis virus in the parasitized host, Heliothis virescens. J. Virol. 48:74-78 (1983).

Krell, P.J.; Stoltz, D.B.: Unusual baculovirus of the parasitoid wasp Apanteles melanoscelus: isolation and preliminary characterization. J. Virol. 29:1118-1130 (1979).

Krell, P.J.; Stoltz, D.B.: Virus-like particles in the ovary of an ichneumonid wasp: purification and preliminary characterization. Virology 101:408-418 (1980).

Krell, P.J.; Summers, M.D.; Vinson, S.B.: Virus with a multipartite superhelical DNA genome from the ichneumonid parasitoid Campoletis sonorensis. J. Virol. 43:859-870 (1982).

Stoltz, D.B.; Vinson, S.B.: Viruses and parasitism in insects. Adv. Virus Res. 24:125-171 (1979).

Stoltz, D.B.: Evidence for chromosomal transmission of polydnavirus DNA. J. gen. Virol. 71: 1051-1056 (1990).

Theilmann, D.A.; Summers, M.D.: Identification and comparison of Campoletis sonorensis virus transcripts in the insect hosts Campoletis sonorensis and Heliothis virescens. Virology 167: 329-341 (1988).

Theilmann, D.A.; Summers, M.D.: Molecular analysis of Campoletis sonorensis virus DNA in the lepidopteran host Heliothis virescens. J. gen. Virol. 67: 1961-1969 (1986).

Theilmann, D.A.; Summers, M.D.: Physical analysis of the Campoletis sonorensis virus multipartite genome and identification of a family of tandemly repeated elements. J. Virol. 61: 2589-2598 (1987).

Webb, B.A.; Summers, M.D.: Venom and viral expression products of the endoparasitic wasp Campoletis sonorensis share epitopes and related sequences. Proc. Natl. Acad. Sci., USA 87: 4961-4965 (1990). 
Morphology

Physicochemical properties

Nucleic acid

Protein

Lipid

Carbohydrate

Antigenic properties

Effect on cells

\section{Properties of The Virus Particle}

Icosahedral, 125-300 nm diameter; spherical nucleoprotein core surrounded by membrane consisting of lipid modified by morphological protein subunits; the released virions of some genera possess a plasma membrane-derived envelope that enhances, but is not required for infectivity.

MW of virions is $500-2000 \times 10^{6} ; S_{20 w}=1300-4450$; density $=1.35-1.6 \mathrm{~g} / \mathrm{cm}^{3}$; members of Iridovirus and Chloriridovirus genera resistant to ether, all others sensitive to ether and nonionic detergents; stable at $\mathrm{pH} 3$ 10 and at $4^{\circ} \mathrm{C}$ for several years; inactivated by $15-30 \mathrm{~min}$ at $55^{\circ} \mathrm{C}$.

One molecule of linear dsDNA, MW $=100-250 \times 10^{6}$. Possibly two molecules in some viruses. $12-30 \%$ by weight of the virus particle. $\mathrm{G}+\mathrm{C} \approx 20-58 \%$; there is no cross-hybridization between genera. The DNA of Ranavirus, Lymphocystivirus, and at least one Iridovirus species is circularly permuted and has direct terminal repeats; the genomic DNA of Ranavirus and Lymphocystivirus contains a high proportion of methylated cytosine.

13-35 structural polypeptides by one and two dimensional PAGE, with MWs ranging from 10-250 x $10^{3}$. Most members that have been examined possess several virionassociated enzymes, in particular an active protein kinase.

Unenveloped particles contain 5-9\% lipid (predominantly phospholipid) as an integral part of the icosahedral shell. Some members have an additional plasma-membranederived envelope.

None has been detected.

Antibodies prepared against virions are often nonneutralizing, but useful in establishing relationships between species. Neutralizing antibodies against Tipula iridescent virus have been produced in rabbits.

Generally cytocidal; most members rapidly inhibit host cell macromolecular synthesis. 
Host range

\section{REPLICATION}

Virus entry is by pinocytosis, with uncoating in phagocytic vacuoles. The host cell nucleus appears to be required for transcription and replication of DNA, but some DNA synthesis, and the assembly of virions into mature particles, takes place in the cytoplasm, where paracrystalline inclusion bodies are readily observed. Release is by lysis or budding. Virions that bud from the host acquire a plasma- or endoplasmic reticulum-derived envelope, but most virus remains cell-associated and unenveloped virions are infectious.

\section{Biological ASPECTS}

Many species appear to have a restricted host range in vivo and in vitro; exceptions are the genus Ranavirus (frog virus 3 ), which grows in a wide variety of cultured cells, and Iridovirus (Tipula iridescent virus), which infects a wide range of insects. Iridovirus type 32 infects both terrestrial isopods and nematodes.

Transmission Both horizontal and vertical.

\section{GENERA}

Small iridescent insect virus group Iridovirus

Large iridescent insect virus group Chloriridovirus

Frog virus group

Ranavirus

Lymphocystis disease virus group Lymphocystivirus

Goldfish virus group (proposed)

\begin{tabular}{llc}
\hline \hline GENUS & SMALL IRIDESCENT & IRIDOVIRUS \\
& INSECT VIRUS GROUP & - \\
\hline TYPE SPECIES & CHILO IRIDESCENT VIRUS & - \\
\hline
\end{tabular}

\section{Properties of the Virus Particle}

Particles $\approx 120 \mathrm{~nm}$ diameter. Complex icosahedral shell contains lipid, but integrity is protected under protein capsid as infectivity is not sensitive to ether. Infected larvae and purified virus pellets produce a blue to purple iridescence. Chilo iridescent virus has circularly permuted and terminally redundant DNA.

\section{OTHER MEMBERS}

Insect iridescent viruses $1,2,6,9,10,16-32$. 


\begin{tabular}{lll}
\hline \hline GENUS & LARGE IRIDESCENT & CHLORIRIDOVIRUS \\
& INSECT VIRUS GROUP & \\
\hline TYPE SPECIES & MOSQUITO IRIDESCENT & - \\
& VIRUS (IRIDESCENT VIRUS - & \\
& TYPE 3, REGULAR STRAIN) \\
\hline
\end{tabular}

\section{Properties of The Virus Particle}

Particle diameter is $\approx 180 \mathrm{~nm}$. Infected larvae and virus pellets of most members iridesce with a yellow-green color.

\section{OTHER MEMBERS}

Insect iridescent viruses $3-5,7,8,11-15$

\section{Probable member}

Chironomus plumosus iridescent

\begin{tabular}{llc}
\hline \hline GENUS & FROG VIRUS GROUP & RANAVIRUS \\
\hline TYPE SPECIES & FROG VIRUS 3 (FV3) & - \\
\hline
\end{tabular}

\section{Properties of The Virus Particle}

Does not cause disease in natural host, adult Rana pipiens, but is lethal for tadpoles and Fowler toads; grows in piscine, avian, and mammalian cells from $12^{\circ} \mathrm{C}$ to $32^{\circ} \mathrm{C}$; structural viral protein causes rapid inhibition of host macromolecular synthesis without interfering with viral replication. DNA-dependent RNA polymerase not found associated with virus particle. DNA contains a high proportion of 5-methyl cytosine and is circularly permuted and terminally redundant. DNA synthesis occurs in 2 stages: (1) synthesis of unit-length molecules in the nucleus and (2) synthesis of concatemers and virion assembly in the cytoplasm. mRNA lacks poly(A).

\section{OTHER MEMBERS}

Frog viruses 1, 2, 5 - 24, L2, L4 and L5

Tadpole edema virus from Rana catesbriana LT 1 - 4 and T6-T20 from newts T21 from Xenopus 


\begin{tabular}{llc}
\hline \hline GENUS & $\begin{array}{l}\text { LYMPHOCYSTIS } \\
\text { DISEASE VIRUS } \\
\text { GROUP }\end{array}$ & LYMPHOCYSTIVIRUS \\
\hline TYPE SPECIES & $\begin{array}{l}\text { FLOUNDER ISOLATE } \\
\text { (LCDV-1) }\end{array}$ & - \\
\hline
\end{tabular}

\section{Properties of the Virus Particle}

Can be transmitted by implantation or injection into centrarchid fish hosts; forms giant host connective tissue cells at $25^{\circ} \mathrm{C}$. Genomic DNA is circularly permuted, terminally redundant, and highly methylated at cytosine residues.

\section{OTHER MEMBERS}

Lymphocystis disease virus dab isolate (LCDV-2)

\section{Possible member}

Octopus vulgaris disease virus

\begin{tabular}{lll}
\hline \hline GENUS & GOLDFISH VIRUS GROUP & - \\
(PROPOSED) & & - \\
\hline $\begin{array}{l}\text { TYPE SPECIES } \\
\text { (PROPOSED) }\end{array}$ & GOLDFISH VIRUS 1 (GFV-1) & - \\
\hline
\end{tabular}

\section{Properties of the Virus Particle}

Does not cause overt disease in natural host. Has a more restricted host range in vitro than amphibian viruses. Produces cytoplasmic vacuolization and cell roundy in goldfish cell line (CAR) at $25^{\circ} \mathrm{C}$.

DNA is highly methylated at cytosine residues, not only at $\mathrm{CpG}$ sequences but most likely, also at $\mathrm{CpT}$.

\section{OTHER MEMBERS}

Goldfish virus 2 (GF-2) 
Derivation of Names irido: from Greek iris, iridos, goddess whose sign was the rainbow, hence iridescent; 'shining like a rainbow,' from appearance of infected larval insects and centrifuged pellets of virions

chloro: from Greek chloros, 'green'

rana: from Latin rana, 'frog'

cysti: from Greek kystis, 'bladder or sac'

lympho: from Latin lympha, 'water'

\section{REFERENCES}

Berry, E.S.; Shea, T.B.; Gabliks, J.: Two iridovirus isolates from Carassius amatus. J. Fish Diseases 6:501-510 (1983).

Darai, G.: Molecular Biology of Iridoviruses. Developments in Molecular Virology. (Kluwer Academic Publishers, Boston, Dordrecht, London, 1990).

Darai, G.; Anders, K.; Koch, H.G.; Delius, H.; Gelderblom, H.; Samalecos, C.; Flügel, R.M.: Analysis of the genome of fish lymphocystis disease virus isolated directly from epidermal tumors of pleuronectes. Virology 126:466-479 (1983).

Delius, H.; Darai, G.; Flügel, R.M.: DNA analysis of insect iridescent virus 6: evidence for circular permutation and terminal redundancy. J. Virol. 49:609-614 (1984).

Essani, K.; Granoff, A.: Amphibian and piscine iridoviruses proposal for nomenclature and taxonomy based on molecular and biological properties. Intervirology 30:187-193 (1989).

Goorha, R.; Murti, K.G.: The genome of an animal DNA virus (frog virus 3) is circularly permuted and terminally redundant. Proc. Natl. Acad. Sci. USA (in press).

Kelly, D.C.; Robertson, J.S.: Icosahedral cytoplasmic deoxyriboviruses. J. gen. Virol. 20: suppl., pp. 17-41 (1973).

Tajbakhsh, S.; Lee, P.E.; Seligy, V.L.: Molecular studies on Tipula iridescent virus (TIV). Abstracts, Sixth Poxvirus/Iridovirus Workshop, pp. 53 (1986).

Willis, D.B.; Granoff, A.: Frog virus 3 DNA is heavily methylated at $\mathrm{CpG}$ sequences. Virology 107:250-257 (1980).

Willis, D.B.: Iridoviridae. Curr. Topics Microbiol. Immunol., Vol. 116 (Springer, Berlin, Heidelberg, New York, Tokyo, 1985). 
Compiled by J.E. Van Etten \& S.A. Ghabrial

\begin{tabular}{llc}
\hline \hline GENUS & dSDNA PHYCOVIRUS & PHYCODNAVIRUS \\
& GROUP & - \\
\hline TYPE SPECIES & PARAMECIUM BURSARIA & \\
& CHLORELLA & \\
& VIRUS - 1 (PBCV - 1) & \\
\hline
\end{tabular}

\section{Properties of The Virus Particle}

Morphology Polyhedral, nonenveloped, $130-200 \mathrm{~nm}$ in diameter.

Physicochemical $S_{20 w}=>2000$. Some of the viruses are disrupted in properties CsCl density gradients.

Nucleic acid Single molecule of linear nonpermuted dsDNA $=250-350$ $\mathrm{kbp}$ with cross-linked hairpin ends. $\mathrm{G}+\mathrm{C}=40-52 \%$. All viral DNAs contain 5-methyldeoxycytidine which vary from 0.1 to $47 \%$. Some DNAs contain $\mathrm{N}^{6}$-methyldeoxyadenosine.

Protein 20 to more than 50 structural proteins, $M W=10->135 x$ $10^{3}$.

Lipid Particles contain 5-10\% lipid as an integral part of the polyhedral shell. Viruses are sensitive to organic solvents but resistant to neutral detergents.

Carbohydrate Some of the viruses contain glycoproteins.

Antigenic

At least two serotypes can be differentiated among Chlorella NC64A viruses by microprecipitin tests using antisera to PBCV-1, CV-NY2C, and CV-NYs1. NC64A viruses which are serologically related, i.e. PBCV-1 and CV-NC1A, may be regarded as strains of the same virus. Chlorella $\mathrm{Pbi}$ viruses do not react with the antisera against NC64A viruses.

\section{REPLICATION}

Viruses attach rapidly and specifically to the cell walls of their host. Uncoating of DNA occurs at cell surface. Capsid assembly and DNA packaging occur in the cytoplasm. Virus release is by lysis of the cells. 
Intracellular site of transcription and DNA replication is unknown.

\section{Biological Aspects}

Host range Host range is limited to eukaryotic algae with the appropriate receptor. Three groups of viruses are delineated based on host specificity:

Paramecium bursaria Chlorella NC64A viruses (NC64A viruses)

Paramecium bursaria Chlorella $\mathrm{Pbi}$ viruses (Pbi viruses)

Hydra virdis Chlorella viruses (HVCV)

Chlorella strains NC64A, ATCC 30562, and N1A (originally symbionts of the protozoan $P$. bursaria), collected in the United States, are the only known hosts for NC64A viruses. Chlorella strain Pbi (originally a symbiont of a European strain of $P$. bursaria) collected in Germany, is the only known host for Pbi viruses. Pbi viruses do not infected Chlorella strains NC64A, ATCC 30562, and N1A. Chlorella strain Florida (originally a symbiont of Hydra viridis) is the only known host for HVCV. NC64A viruses are placed in 16 subgroups based on plaque size, serological reactivity, resistance to restriction endonucleases, and nature and content of methylated bases.

\section{OTHER MEMBERS}

Chlorella NC64A viruses (Thirty seven NC64A viruses including PBCV-1, the type species of the family are known: Chlorella virus NE-8D (CV-NE8D; synonym NE8D), CV-NYb1, CV-CA4B, CV-AL1A, CV-NY2C, CVNC1D, CV-NC1C, CV-CA1A, CV-CA2A, CV-IL2A, CV-IL2B, CV-IL3A, CV-IL3D, CV-SC1A, CV-SC1B, CV-NC1A, CV-NE8A, CV-AL2C, CV-MA1E, CVNY2F, CV-CA1D, CV-NC1B, CV-NYs1, CV-IL5-2s1, CV-AL2A, CV-MA1D, CV-NY2B, CV-CA4A, CVNY2A, CV-XZ3A, CV-SH6A, CV-BJ2C, CV-XZ6E, CV-XZ4C, CV-XZ5C, CV-XZ4A).

Chlorella Pbi viruses (CVA-1, CVB-1, CVG-1, CVM-1, and CVR-1).

Hydra viridis Chlorella viruses (HVCV-1, HVCV-2, and HVCV-3).

Derivation of Name phyco: from Greek phycos, 'algae'.

dna (= sigla for deoxyribonucleic acid) 


\section{REFERENCES}

Reisser, W.; Burbank, D.E.; Meints, S.M.; Meints, R.H.; Becker, B.; van Etten, J.L.: A comparison of viruses infecting two different Chlorella-like green algae. Virology 167: 143-149 (1988).

Schuster, A.M.; Burbank, D.E.; Meister, B.; Skrdla, M.P.; Meints, R.H.; Hattman, S.; Swinton, D.; van Etten, J.L.: Characterization of viruses infecting an eukaryotic Chlorella-like green alga. Virology 150: 170-177 (1986).

van Etten, J.L.; Meints, R.H.; Burbank, D.E.; Kuczmarski, D.; Cuppels, D.A.; Lane, L.C.: Isolation and characterization of a virus from the intracellular green alga symbiotic with Hydra viridis. Virology 113: $704-711$ (1981).

van Etten, J.L.; Schuster, A.M.; Meints, R.H.: Viruses of eukaryotic Chlorella-like algae. In Koltin, Y., Leibowitz, M.G.: Viruses of Fungi and Simple Eukaryotes, pp. 411-428 (Dekker, New York 1988). 


FAMILY ADENOVIRUS FAMILY ADENOVIRIDAE

Morphology

Reported by W.C. Russell

\section{Properties of The Virus Particle}

Physicochemical properties

Nucleic acid

Protein

Lipid

Carbohydrate

Antigenic properties
Nonenveloped isometric particles with icosahedral symmetry, $70-90 \mathrm{~nm}$ in diameter, with 252 capsomers, 8 $9 \mathrm{~nm}$ in diameter. 12 vertex capsomers (or penton bases) carry one or two filamentous projections (or fibers) of characteristic length; 240 nonvertex capsomers (or hexons) are different from penton bases and fibers.

$\mathrm{MW} \approx 170 \times 10^{6} ;$ buoyant density in $\mathrm{CsCl}=1.32-1.35$ $\mathrm{g} / \mathrm{cm}^{3}$. Stable on storage in frozen state: no inactivation by lipid solvents.

Single linear molecule of dsDNA of MW $=20-25 \times 10^{6}$ for viruses isolated from mammalian $(M)$ species or $\approx 30$ $\mathrm{x} 10^{6}$ from avian (A) species. A virus coded terminal protein is covalently linked to each 5 '-end. The sequence of the human adenovirus 2 genome is $35,937 \mathrm{bp}$ and contains an inverted terminal repetition (ITR) of $103 \mathrm{bp}$. ITR's of 50-200 bp's are found in all viruses sequenced. $\mathrm{G}+\mathrm{C}$ content varies from $48-61 \%$ (mastadenoviruses) and $54-55 \%$ (aviadenoviruses).

At least 10 polypeptides in virion, MWs $=5-120 \times 10^{3}$ (M).

None.

Fibers are glycoproteins.

Antigens at the surface of virion are mainly type-specific; hexon for neutralization; fiber for neutralization and hemagglutination-inhibition. Soluble antigens are surplus capsid proteins which have not been assembled; free hexon mainly reacts as a genus-specific antigen, which is shared by most mastadenoviruses and differs from the corres-ponding antigens in aviadenoviruses.

Hexons and other soluble antigens carry numerous epitopes, some of which have genus-, subgenus-, intertype- and/or type-specific determinants differentiated using monoclonal antibodies. The genus specific antigen is on the basal surface of the hexon whereas the serotype specific antigens (see below) are mainly confined to the external surface. 
Effect on cells

\section{Molecular biology}

\section{Virus inclusion bodies}

Host range

Transmission

Definition of serotype
Characteristic CPE without lysis occurs during multiplication in cell cultures. Most viruses haemagglutinate blood cells of various host species. Some are oncogenic in rodents and may transform cells and one (human adenovirus 12) induces retinal tumors in the baboon.

\section{REPLICATION}

(as exemplified by human adenovirus 2 ).

Productive cycle in vitro: attaches to specific cell receptors via fiber, probably enters cell by endocytosis. Transcription, DNA replication and virus assembly in nucleus. Slow virus release after cell death. Virus shuts off host DNA synthesis early and RNA and protein synthesis late. Transcription from five early, three intermediate and one major late polymerase II promoter. All primary transcripts are capped and polyadenylated. Complex alternate splicing produces families of mRNAs. VA genes transcribed by cell RNA polymerase III. DNA replication by strand displacement, using virus coded DNA polymerase and terminal protein priming mechanism. Transformation in vitro: integration into host genome of early region I and expression of E1A and E1B proteins necessary and sufficient to establish fully transformed phenotype.

Intranuclear inclusions, containing DNA, and viral antigens and virions in paracrystalline array or otherwise.

\section{Biological ASPECTS}

Natural host range mostly confined to one host or closely related animal species; this holds also for cell cultures. Some human adenoviruses cause productive infection in rodent cells with low efficiency. Several types cause tumors in newborn hosts of heterologous species. Subclinical infections are frequent in various virus/host systems.

Direct or indirect transmission from throat, feces, eye or urine depending upon serotype.

A serotype is defined on the basis of its immunological distinctiveness, as determined by quantitative neutralization with animal antisera (from other species). A serotype has either no cross-reaction with others or shows a homologous-to-heterologous titer ratio of $>16$ in both directions. If neutralization shows a certain degree of 
cross-reaction between two viruses in either or both directions (homologous-to-heterologous titer ratio of 8 or 16), distinctiveness of serotype is assumed if: (i) the hemagglutinins are unrelated, as shown by lack of crossreaction on hemagglutination-inhibition; or (ii) substantial biophysical/biochemical differences of the DNAs exist.

Subgenera

Naming of serotypes

Forty seven human adenovirus serotypes are classified according to their structural, biochemical, biological and immunological characteristics into 6 subgenera (formerly sub-groups) A to $\mathrm{F}$.

Human adenoviruses are designated by the letter ' $h$ ' plus a number, viruses from animals by a 3-letter code from the genus of the respective host plus a number as in the following table. However, some of these serotype designations are more colloquially abbreviated as follows: -h-Ad; sim-SAV; bos-BAV; sus-PAV; can-CAV; musMAV; gal-FAV.

\section{GENERA}

Mammalian adenoviruses Avian adenoviruses

Mastadenovirus Aviadenovirus

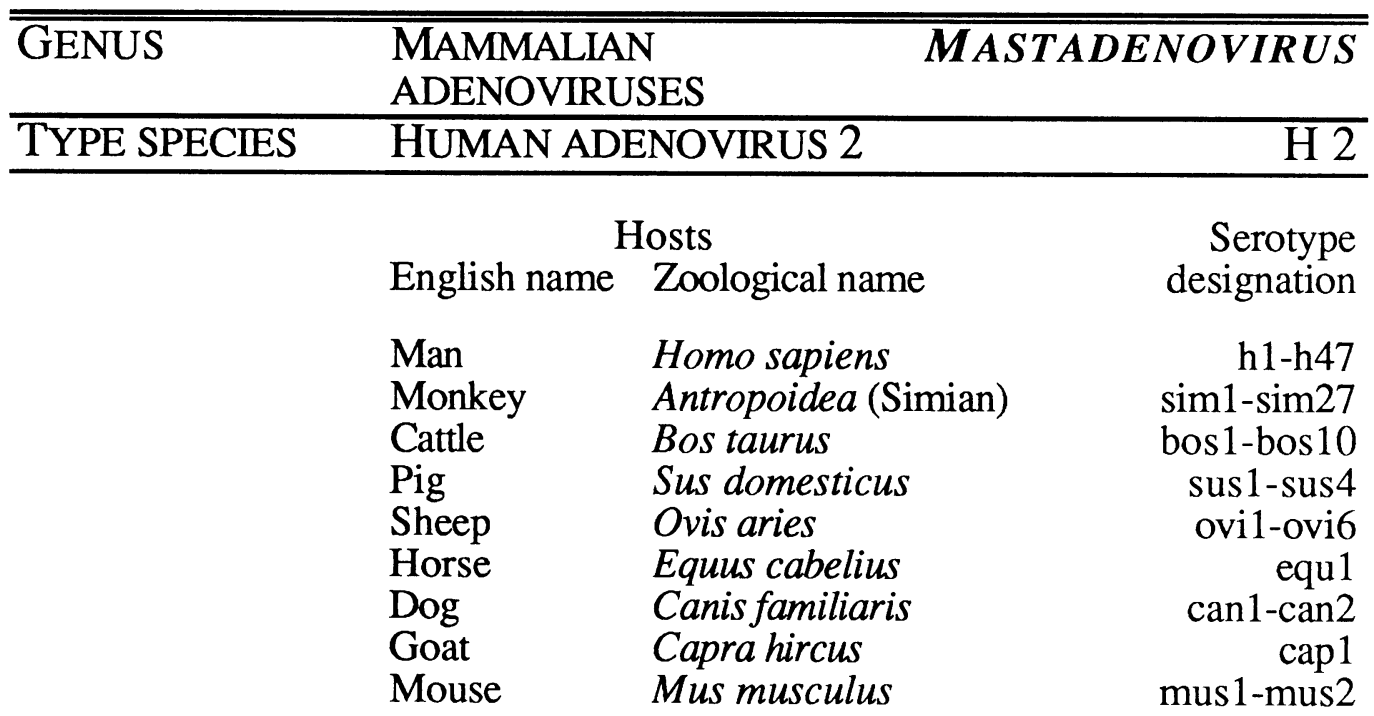




\begin{tabular}{llrr}
\hline \hline GENUS & \multicolumn{2}{c}{ AVIAN ADENOVIRUSES } & AVIADENOVIRUS \\
\hline TYPE SPECIES & FOWL ADENOVIRUS 1 (CELO) & GAL 1 \\
\hline \multicolumn{3}{c}{ Hosts } & Serotype \\
& English name & Zoological name & designation \\
& Fowl & Galius domesticus & gal1-gal2 \\
& Turkey & Meleagris gallopavo & mel1-mel3 \\
& Goose & Anser domesticus & ans1-ans3 \\
& Pheasant & Phasianus colchicus & pha1 \\
& Duck & Anas domestica & ana1-ana2
\end{tabular}

Derivation of Names adeno: from Greek aden, adenos, "gland"; adenoviruses were first isolated from human adenoid tissue avi: from Latin avis, "bird" mast: from Greek mastos, "breast" - a by-form is Greek and Latin mamma, hence mammalian.

\section{REFERENCES}

Adrian, T.; Wadell, G.; Hierholzer, J.C.; Wigand, R.: DNA restriction analysis of adenovirus prototypes 1 to 41 . Arch. Virol. 91:277-290 (1986).

Ginsberg, H.S.: The Adenoviruses (Plenum Press, New York, 1984).

Ginsberg, H.S.; Young, C.S.H.: Genetics of adenoviruses. In Fraenkel Conrat, H.; Wagner, R.R. (eds.) Comprehensive Virology, Vol. 9, pp. 27-88 (Plenum Press, New York, 1977).

Green, M.; Mackey, J.K.; Wold, W.S.M.; Rigden, P.: Thirty-one human adenovirus serotypes (Ad1-Ad31) form five groups (A-E) based upon DNA genome homologies. Virology 93:481-492 (1979).

Hierholzer, J.C.; Wigand, R.; Anderson, L.J.; Adrian, T.; Gold, J.W.M.: Adenoviruses from patients with AIDS; a plethora of serotypes and a description of five new serotypes of subgenus D (types 43-47). J. Infect. Dis. 158: 804-813 (1988).

Horner, G.W.; Hunter, K.; Bartha, A.; Benko, M.: A new subgroup of bovine adenovirus proposed as prototype strain 10. Arch. Virol. 109: 121-124 (1989).

Horwitz, M.S.: Adenoviridae and their replication. In Fields, B.N.; Knipe, D.M., (eds.), Virology, Vol. 2, 2nd edit., pp. 1679-1722 (Raven Press, New York, 1990).

Kalter, S.S.: Enteric viruses of nonhuman primates. Vet. Pathol. 19 Suppl. 7:33-43 (1982).

Mautner, V.: Adenoviridae. In Porterfield, J.S. (ed.), Andrewes' Viruses of Vertebrates, pp. 249-284 (Bailliore Tindall, 1989).

Norrby, E.; Bartha, A.; Boulanger, P.; Dreizin, R.S.; Ginsberg, H.S.; Kalter, S.S.; Kawamura, H.; Rowe, W.P.; Russell, W.C.; Schlesinger, R.W.; Wigand, R.: Adenoviridae. Intervirology 7:117-125 (1976).

Pettersson, U.; Wadell, G.: Antigenic structure of the adenoviruses. In van Regenmortel, M.H.V.; Neurath, A.R. (eds.), Immunochemistry of viruses. The basis for serodiagnosis and vaccines pp. 295-323 (Elsevier/North Holland, Amsterdam, 1985).

Roberts, R.J.; Akusjarvi, G.; Alestrom, P.; Gelinas, R.E.; Gingeras, T.R.; Sciaky, D.; Pettersson, U.: A consensus sequence for the adenovirus-2 genome. In Doerfler, W. 
(ed.), Adenovirus DNA. The viral genome and its expression, pp. 1-51 (Martinus Nijhoff Publishing, Boston, 1986).

Shenk, T.; Williams, J.: Genetic analysis of adenoviruses. Cur. Topics Microbiol. Immunol. 111:1-39 (1984).

van der Eb, A.J.; Bernards, R.: Transformation and oncogenicity by adenoviruses. Cur. Topics. Microbiol. Immunol. 110:23-51 (1984).

Wadell, G.: Classification of human adenoviruses by SDS-polyacrylamide gel electrophoresis of structural polypeptides. Intervirology 11:47-57 (1979).

Wadell, G.; Hammarskjold, M.-L.; Winberg, G.; Varsanyi, T.M.; Sundell, G.: Genetic variability of adenoviruses. Ann. N. Y. Acad. Sci. 354:16-42 (1980).

Wigand, R.; Adrian, T.; Bricout, F.: A new human adenovirus of subgenus D: Candidate adenovirus type 42. Arch. Virol. 94:283-286 (1987).

Wigand, R.; Bartha, A.; Dreizin, R.S.; Esche, H.; Ginsberg, H.S.; Green, M.; Hierholzer, J.C.; Kalter, S.S.; McFerran, J.B.; Pettersson, U.; Russell, W.C.; Wadell, G.: Adenoviridae; Second report. Intervirology 18:169-176 (1982).

Zsak, L.; Kisary, J.: Grouping of fowl adenoviruses based upon the restriction patterns of DNA generated by BamH I and Hind III. Intervirology 22:110-114 (1984). 


\begin{tabular}{llc}
\hline \hline GENUS & $\begin{array}{l}\text { RHIZIDIOMYCES VIRUS } \\
\text { GROUP } \\
\text { (POSSIBLE AFFINITIES TO THE ADENOVIRIDAE FAMILY) }\end{array}$ \\
\hline TYPE SPECIES & $\begin{array}{l}\text { RHIZIDIOMYCES VIRUS } \\
\text { (FROM RHIZIDIOMYCES SP. } \\
\text { ISOLATE F) }\end{array}$ \\
\hline
\end{tabular}

Compiled by K.W. Buck \& S.A. Ghabrial

\section{Properties of the Virus Particle}

Morphology Isometric, particles $\approx 60 \mathrm{~nm}$ in diameter.

Physicochemical $S_{20 w} \approx 625 \mathrm{~S}$; buoyant density in $\mathrm{CsCl} \approx 1.314 \mathrm{~g} / \mathrm{cm}^{3}$. properties

Nucleic acid Single molecule of dsDNA, MW $\approx 16.8 \times 10^{6}, \mathrm{G}+\mathrm{C} \approx$ $42 \%$.

Protein At least 14 polypeptides with MWs $=84.5-26 \times 10^{3}$ with the largest one being dominant.

Lipid None detected.

Carbohydrate None detected.

REPLICATION

Particles appear first in the nucleus.

\section{Biological ASPECtS}

The virus appears to be transmitted in a latent form in zoospores of the fungus host. Activation of the virus under stress conditions, such as heat, low nutrition or ageing, results in cèll lysis.

Derivation of rhizidio from name of the host Rhizidiomyces sp.

Names

\section{REFERENCES}

Dawe, V.H.; Kuhn, C.W.: Virus-like particles in the aquatic fungus, Rhizidiomyces. Virology 130:10-20 (1983).

Dawe, V.H.; Kuhn, C.W.: Isolation and characterization of a double-stranded DNA mycovirus infecting the aquatic fungus, Rhizidiomyces. Virology 130:21-28 (1983). 


FAMILY PAPOVAVIRUS GROUP PAPOVAVIRIDAE

Reported by R. Frisque

Morphology

\section{Properties of the Virus Particle}

Nonenveloped, icosahedral particles $40-55 \mathrm{~nm}$ in diameter; 72 capsomers in skew arrangement; filamentous forms occur.

Physicochemical properties

Nucleic acid

Protein

Lipid

Carbohydrate

Antigenic properties

Effects on cells
$\mathrm{MW}=25-47 \times 10^{6} ; \mathrm{S}_{20 \mathrm{w}}=240-300$; buoyant density in $\mathrm{CsCl}=1.34 \mathrm{~g} / \mathrm{cm}^{3}$. Resistant to ether, acid and heat treatment.

One molecule circular dsDNA, MW $=3-5 \times 10^{6} ; \mathrm{G}+\mathrm{C}=$ $40-50 \%, 10-13 \%$ of virion by weight.

6-9 polypeptides, MW $=3-82 \times 10^{3}$. Low MW components are cellular histones.

None.

None.

Different species antigenically distinct by neutralization and $\mathrm{HI}$ tests; antisera prepared against disrupted virions detect common antigens shared by other species belonging to the same genus.

Cytolytic in cells of host of origin; may transform cells from other species; several species of virus haemagglutinate by reacting with neuraminidase-sensitive receptors; no tissue culture systems for papillomaviruses.

\section{REPLICATION}

Virions attach to cellular receptors, are engulfed and transported to nucleus; host cell enzymes are derepressed and cellular DNA synthesis is stimulated; expression of viral genome divided into early and late events; host cell histones are incorporated into virions during maturation in nucleus; virions released by lysis of infected cells. Replication of papillomaviruses in vivo is dependent on the terminal differentiation of keratinocytes.

\section{Biological ASPECTS}

Each virus has its own host range in nature and in the laboratory. Transformation tends to occur in cells which do not support replication of virus. 
Transmission Contact and airborne infection. Some human papillomaviruses may be sexually transmitted.

\section{GENERA}

Papillomavirus

Polyomavirus

\begin{tabular}{llr}
\hline \hline GENUS & \multicolumn{1}{c}{ PAPILLOMAVIRUS } \\
\hline TYPE SPECIES & RABBIT (SHOPE) & PAPILLOMAVIRUS \\
& PAPILLOMA VIRUS & SYLVILAGI \\
\hline
\end{tabular}

\section{Properties of The Virus Particle}

Morphology Particles $50-55 \mathrm{~nm}$ in diameter.

Physicochemical $S_{20 w} \approx 300$. properties

Nucleic acid

$\mathrm{MW} \approx 5 \times 10^{6} ; \mathrm{G}+\mathrm{C}=40-50 \%$. ORFs located on one strand of DNA.

Antigenic properties

\section{Host range}

Each virus species contains a distinct surface antigen, but all members of the genus share one common antigen revealed by disrupting the virions.

\section{Biological ASPECts}

Cause papillomas in natural hosts and related species. Host and tissue-specific viruses induce papillomas in skin and mucous membranes but do not grow in cell cultures. Warts may convert to malignancy.

\section{OTHER MEMBERS}

Members of this genus are known from humans ( $>63$ types), chimpanzee, colobus and rhesus monkeys, cow (6 types), deer, dog, horse, sheep, elephant, elk, opossum, multimammate and European harvest mice, turtle, chaffinch and parrot. 


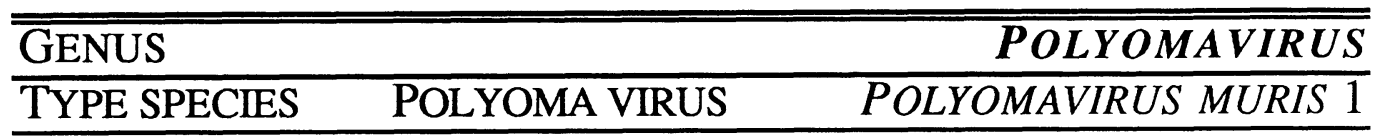

Properties of the Virus Particle

Morphology Particles 40-45 $\mathrm{nm}$ in diameter.

Physicochemical $S_{20 w} \approx 240$. properties

Nucleic acid

$\mathrm{MW} \approx 3 \times 10^{6} ; \mathrm{G}+\mathrm{C}=40-48 \%$. ORFs located on both strands of DNA.

Antigenic properties

Effects on cells
Several species haemagglutinate. Whole viruses show no serological cross-reactivity between most species, but a common genus antigen can be detected in disrupted virions of all species. $T$ antigens induced by primate viruses, cross-react.

Inapparent infections in most hosts. Oncogenic in hosts (chiefly immunodeficient newborn hamsters) which are often different from species of origin of virus. They have a restricted host range and replicate in cell culture. Cells which do not support replication may be transformed. Viral DNA integrates into cellular chromosomes of transformed cells.

\section{OTHER MEMBERS}

Polyomavirus muris 2 (K)

Polyomavirus hominis 1 (BK)

Polyomavirus hominis 2 (JC)

Polyomavirus sylvilagi (Rabbit kidney vacuolating)

Polyomavirus maccacae 1 (SV40)

Polyomavirus papionis 1 (SA12)

Polyomavirus papionis 2

Polyomavirus cercopitheci (lymphotropic)

Polyomavirus bovis (WRSV)

Other possible members have been found in pigs and hamsters. 
Derivation of Names

papova: sigla, from papilloma, polyoma, and vacuolating agent (early name for SV40).

papilloma: from Latin papilla, 'nipple, pustule', and Greek suffix -oma, used to form nouns denoting 'tumors'

polyoma: from Greek poly, 'many', and -oma, denoting 'tumors'.

\section{REFERENCES}

Melnick, J.L.; Allison, A.C.; Butel, J.S.; Eckhart, W.; Eddy, B.E.; Kit, S.; Levine, A.J.; Miles, J.A.R.; Pagano, J.S.; Sachs, L.; Vonka, V.: Papovaviridae. Intervirology 3:106-120 (1974).

Salzman, N.P.: The Papovaviridae: The Polyomaviruses, Vol. 1 (Plenum Press, New York, 1986).

Salzman, N.P.; Howley, P.M.: The Papovaviridae: The Papilloma-viruses, Vol. 2 (Plenum Press, New York, 1987). 


\begin{tabular}{|lll|}
\hline GROUP & $\begin{array}{l}\text { CAULIFLOWER } \\
\text { MOSAIC VIRUS (295) }\end{array}$ & CAULIMOVIRUS \\
\hline
\end{tabular}

Revised by R. Hull

\begin{tabular}{lll}
\hline TYPE MEMBER & CAULIFLOWER MOSAIC & - \\
& $\begin{array}{l}\text { VIRUS (CAMV) (24; 243) } \\
\text { (CABBAGE B, DAVIS ISOLATE) }\end{array}$ & \\
\hline
\end{tabular}

\section{Properties of the Virus Particle}

Morphology Isometric particles $\approx 50 \mathrm{~nm}$ in diameter.

Physicochemical $\mathrm{MW} \approx 20 \times 10^{6} ; \mathrm{S}_{20 \mathrm{w}} \approx 208 ; \mathrm{D} \approx 0.75 \times 10^{-7} \mathrm{~cm}^{2} / \mathrm{s} ;$ properties apparent partial specific volume $\approx 0.704$; buoyant density in $\mathrm{CsCl} \approx 1.37 \mathrm{~g} / \mathrm{cm}^{3}$; particles very stable.

Nucleic acid

Protein

One molecule of dsDNA; open circular molecule with single-strand discontinuities at specific sites, the transcribed $(\alpha)$ strand with one and the non-transcribed $(\beta)$ strand with two discontinuities; DNAs of four CaMVs (isolates Cabb S with 8,024 bp, CM1841 with 8,031 bp, $\mathrm{D} / \mathrm{H}$ with $8,016 \mathrm{bp}$ and Xinjiang with $8,060 \mathrm{bp}$ ) have been sequenced. Six or possibly 8 ORFs (putative genes) are present on the $\alpha$ strand. The $\beta$ strand is noncoding.

Capsid protein is translated from ORF IV, and assembled into capsids as $57 \times 10^{3}$ phosphorylated polypeptide. Rapid degradation occurs in vivo (and perhaps also during purification) to give several polypeptide forms, MW predominantly $\approx 42 \times 10^{3}$ and $37 \times 10^{3}$.

Lipid None.

Carbohydrate Coat protein has some glycosylation.

Antigenic properties

Efficient immunogens; serological relationships among some members.

\section{REPLICATION}

Transcription occurs in the nucleus from a DNA template with properties of a minichromosome. Two major transcripts (19S and 35S) are found. The 19S transcript is from ORF VI, and translates to a MW $=62 \times 10^{3}$ protein found in the cytoplasmic viral inclusion body in which mature virus particles accumulate; these electrondense inclusion bodies are characteristic of the group. The 35S transcript has not been translated in vitro but is 
though to be the mRNA of several of the ORFs. The $35 \mathrm{~S}$ transcript is 180 nucleotides longer than the full length viral DNA (i.e., it contains a 180 nucleotide terminal repeat), and is thought to be a template for replication of the viral genome by reverse transcription. ORF $V$ may code for the replication enzyme.

\section{Biological ASPECtS}

\section{Host range Narrow.}

Transmission Transmissible experimentally by mechanical inoculation; transmitted by aphids in a semipersistent manner. Transmission of CaMV requires a virus-coded protein (the product of ORF II) also located within inclusion bodies.

\section{OTHER MEMBERS}

Blueberry red ringspot (327)

Carnation etched ring (182)

Dahlia mosaic (51)

Figwort mosaic

Horseradish latent

Mirabilis mosaic

Peanut chlorotic streak

Soybean chlorotic mottle (331)

Strawberry vein banding (219)

Thistle mottle

\section{Possible members}

Aquilegia necrotic mosaic

Cassava vein mosaic

Cestrum virus

Petunia vein clearing

Plantago virus 4

Sonchus mottle

Derivation of caulimo: sigla from cauliflower mosaic 


\section{REFERENCES}

Covey, S.N.; Hull, R.: Advances in cauliflower mosaic virus research. Oxford Surveys of Plant Mol. Cell. Biol. 2:339-346 (1985).

Covey, S.N.: Organization and expression of the cauliflower mosaic virus genome, In Davies, J.W. (ed.), Molecular Plant Virology, Replication and Gene Expression, Vol. II, pp. 121-160 (CRC Press, Boca Raton, Fl, 1985).

Francki, R.I.B.; Milne, R.G.; Hatta, T.: Caulimovirus group, In Atlas of plant viruses, Vol. I, pp. 17-32, (CRC Press, Boca Raton, Fl, 1985).

Frank, A.; Guilley, H.; Jonard, G.; Richards, K.; Hirth, L.: Nucleotide sequence of cauliflower mosaic virus DNA. Cell 21:285-294 (1980).

Gardner, R.C.; Howarth, A.J.; Hahn, P.; Brown-Luedi, M.; Shepherd, R.J.; Messing, J.: The complete nucleotide sequence of an infectious clone of cauliflower mosaic virus by M13mp7 shotgun sequencing. Nuc. Acids Res. 9:2871-2888 (1981).

Kruse, J.; Timmins, P.; Witz, J.: The spherically averaged structure of a DNA isometric plant virus: cauliflower mosaic virus. Virology 159: 166-168 (1987).

Maule, A.J.: Replication of caulimoviruses in plants and protoplasts, In Davies, J.W. (ed.), Molecular Plant Virology, Replication and Gene Expression, Vol. II, pp. 161-190 (CRC Press, Boca Raton, Fl., 1985).

Pfeiffer, P.; Hohn, T.: Involvement of reverse transcription in the replication of cauliflower mosaic virus: A detailed model and test of some aspects. Cell 33:781-789 (1983).

Richins, R.D.; Shepherd, R.J.: Physical maps of the genomes of dahlia mosaic virus and mirabilis mosaic virus - two members of the caulimovirus group. Virology 124:208214 (1983). 


\section{GROUP COMMELINA YELLOW}

MOTTLE VIRUS GROUP

Compiled by B.E.L. Lockhart \& R. Hull

\begin{tabular}{lll}
\hline TYPE MEMBER & COMMELINA YELLOW & - \\
& MOTTLE VIRUS (COYMV) & \\
\hline
\end{tabular}

Morphology Bacilliform particles $\approx 130 \times 30 \mathrm{~nm}$.

Physicochemical CoYMV has a density in $\mathrm{CsCl}$ of $1.37 \mathrm{~g} / \mathrm{cm}^{3}$, cacao properties swollen shoot virus has a $S_{20 w}$ of 218.

Nucleic acid One molecule of dsDNA: open circular molecules with single-strand discontinuities at specific sites, one in each strand. Mealybug transmitted viruses have genomes $\approx$ $7.5 \mathrm{kbp}$ (7489 bp in CoYMV), and rice tungro bacilliform virus has a genome of $\approx 8.0 \mathrm{kbp}$.

Protein Two protein species $\approx 40 \times 10^{3}$ and $35 \times 10^{3}$.

Lipid None determined.

Carbohydrate None detected.

Antigenic properties

Moderately efficient immunogens, serological relationships among some members.

\section{REPLICATION}

Mechanism not determined but, as the genome has various properties in common with caulimoviruses, it is thought to involve reverse transcription.

\section{Biological ASpects}

\section{Host range Narrow.}

Transmission Most members and possible members not transmissible mechanically; those that are, are only transmitted with difficulty. Members and possible members for which a vector is known are all transmitted by mealybugs in a semi-persistent manner except for rice tungro bacilliform virus which is leafhopper transmitted in association with rice tungro spherical virus, and rubus yellow net which is aphid transmitted. 


\section{OTHER MEMBERS}

Banana streak

Sugarcane bacilliform

Possible members

Aucuba ringspot

Cacao swollen shoot (10)

Canna yellow mottle

Colocasia bacilliform

Dioscorea bacilliform

Kalanchoe top-spotting

Mimosa bacilliform

Rubus yellow net (188)

Rice tungro bacilliform

Schefflera ringspot

Yucca bacilliform

\section{REFERENCES}

Lockhart, B.E.L.: Evidence for a double-stranded circular DNA genome in a second group of plant viruses. Phytopathology 80: 127-131 (1990). 
Revised by H.-W. Ackermann

\begin{tabular}{l} 
GENUS \\
\hline TYPE SPECIES \\
\hline Morphology \\
Physicochemical \\
properties
\end{tabular}

PHAGES WITH DOUBLE CAPSIDS TECTIVIRUS
PHAGE PRD1 GROUP

\section{Properties of the Virus Particle}

Icosahedral, $63 \mathrm{~nm}$ diameter. Some show single, $20 \mathrm{~nm}$ long spikes on vertices. Double capsid consisting of a rigid outer shell $3 \mathrm{~nm}$ thick and a flexible inner coat $5-6 \mathrm{~nm}$ thick. The latter is destroyed by lipid solvents. Upon nucleic acid ejection, a tail-like structure of about $60 \mathrm{~nm}$ in length appears. No envelope.

properties

Nucleic acid

Protein

Lipid

Carbohydrate Not known.

\section{REPLICATION}

Virions adsorb to tips of plasmid-dependent pili of gramnegative bacteria . Assembly in nucleoplasm; capsid is assembled first and later filled with DNA. Virulent, lysis.

\section{Biological ASPeCts}

Host range Gram-negative bacteria carrying certain drug-resistance plasmids (enterobacteria, Acinetobacter, Pseudomonas, Vibrio) and Bacillus.

\section{OTHER MEMBERS}

L17, PR3, PR4, PR5, PR772 (gram-negatives); AP50 series (6 isolates), Bam35, $\phi$ NS11 (Bacillus). 
Derivation of tecti: from Latin tectus, 'covered'

Name

\section{REFERENCES}

Ackermann, H.-W.; DuBow, M.S.: Viruses of Prokaryotes, Vol. II, pp 171-218 (CRC Press, Boca Raton, Fl., 1987).

Bamford, D.H.; Rouhiainen, L.; Takkinen, K.; Söderlund, H.: Comparison of the lipidcontaining bacteriophages PRD1, PR3, PR4, PR5, and L17. J. gen. Virol. 57:365-373 (1981). 


\begin{tabular}{|lll}
\hline FAMILY & PM2 PHAGE GROUP CORTICOVIRIDAE \\
\hline
\end{tabular}

Revised by H.-W. Ackermann

\begin{tabular}{llc}
\hline \hline GENUS & PM2 PHAGE GROUP & CORTICOVIRUS \\
\hline TYPE SPECIES & ALTEROMONAS PHAGE PM2 & - \\
\hline
\end{tabular}

Properties of The Virus Particle

Morphology Icosahedral, $\approx 60 \mathrm{~nm}$ in diameter, with brush-like spikes on vertices. Multilayered capsid. No envelope.

Physicochemical $\mathrm{MW} \approx 49 \times 10^{6} ; \mathrm{S}_{20 \mathrm{w}}=230$; buoyant density in $\mathrm{CsCl}=$ properties $1.28 \mathrm{~g} / \mathrm{cm}^{3}$. Infectivity is ether-, chloroform-, and detergent-sensitive.

Nucleic acid One molecule of circular supercoiled dsDNA, MW $\approx 6 \mathrm{x}$ $10^{6}, 13 \%$ by weight of particle; $\mathrm{G}+\mathrm{C}=43 \%$.

Protein Four proteins with MWs $=4.7-44 \times 10^{3}$. Protein I forms spikes, II forms outer shell; inner shell of virion contains a transcriptase (protein IV?). Proteins III and IV behave as lipoproteins.

Lipid

Carbohydrate Protein IV is a glycoprotein.

\section{REPLICATION}

Adsorption to cell wall. Assembly near plasma membrane, no inclusion bodies. Virulent, lysis.

\section{Biological Aspects}

Host range

\section{Alteromonas}

Possible member

06N-58P (Vibrio)

Derivation of Name cortico: from Latin cortex, corticis, 'bark, crust' 


\section{REFERENCES}

Ackermann, H.-W.; DuBow, M.S.: Viruses of Prokaryotes, vol. II, pp 171-218 (CRC Press, Boca Raton, Fl., 1987).

Franklin, R.M.; Marcoli, R.; Satake, H.; Schäfer, R.; Schneider, D.: Recent studies on the structure of bacteriophage PM2. Med. Microbiol. Immunol. 164:87-95 (1977).

Mindich, L.: Bacteriophages that contain lipid. In Fraenkel-Conrat, H.; Wagner, R.R. (eds.), Comprehensive Virology, Vol. 12, pp. 271-335 (Plenum Press, New York 1978). 


\begin{tabular}{|lll|}
\hline $\begin{array}{l}\text { ORDER } \\
\text { (POSSIBLE) }\end{array}$ & TAILED PHAGES & - \\
\hline
\end{tabular}

Compiled by H.-W. Ackermann

Morphology

Physicochemical properties

Nucleic acid

Protein

Lipid

\section{GENERAL}

Tailed phages are extremely variable in dimensions and physico-chemical properties. Over 3,000 descriptions have been published. Three families are distinguished by tail structure, but no basis for genus definition is apparent. Each family includes large numbers of species.

\section{Properties of The Virus Particle}

Virions consist of head (capsid), tail, and fixation organelles. No envelope. Heads are isometric or elongated and are icosahedra or derivatives thereof (proposed triangulation numbers $\mathrm{T}=1, \mathrm{~T}=9, \mathrm{~T}=13, \mathrm{~T}=$ 81). Capsomers are seldom visible and heads usually appear smooth. Isometric heads are $45-170 \mathrm{~nm}$ in diameter. Elongated heads are up to $230 \mathrm{~nm}$ long. Tails are helical and contractile, long and noncontractile, or short. They may have base plates, spikes, or fibers, and undergo functional changes. Some phages have collars and head or collar appendages. Aberrant structures are frequent.

$\mathrm{MW}=29-470 \times 10^{6}$, may be higher; $S_{20 \mathrm{w}}=226-1,230$, may be higher; buoyant density in $\mathrm{CsCl}=1.41-1.55$ $\mathrm{g} / \mathrm{cm}^{3}$. Infectivity is generally ether- and chloroformresistant. Detergent sensitivity is variable.

One molecule of linear dsDNA; MW $=11-490 \times 10^{6} ; 25$ $62 \%$ by weight of particle. $\mathrm{G}+\mathrm{C}=27-72 \%$ and usually close to that of the host. DNA may contain unusual bases, which replace normal bases partially or completely, and unusual sugars. It may be circularly permuted, terminally redundant, or nicked and may have cohesive ends, strands of different weight, or terminal proteins. Genes with related functions frequently cluster together.

Virions contain many different polypeptides (5-50?) (MW $=4-200 \times 10^{3}$ ). Lysozyme is located at the tail tip; other enzymes may be present.

Reported in a few phages, mostly of Mycobacterium. Presence in others is controversial. 
Carbohydrate Glycoproteins, glycolipids, hexosamine, and a polysaccharide have been found in a few cases.

\section{Antigenic} properties

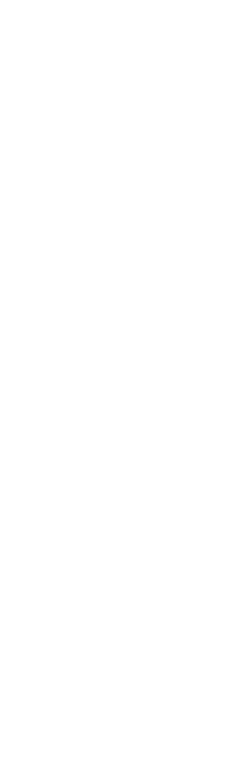

Host range
Virions are antigenically complex and efficient immunogens.

\section{REPLICATION}

Tailed phages are virulent or temperate. Temperate phages have a vegetative and a prophage state. Prophages are integrated in, and replicate synchronously with the host genome, or are in the cytoplasm and behave as plasmids. Some phages have transduction or conversion ability. Virions adsorb tail first to cell wall, capsule, flagella, or pili. The cell wall is digested by phage lysozyme. Infecting DNA replicates in a semiconservative way. Replicative intermediates are concatemers or circles. Replication depends on host polymerases (exceptions). Assembly is complex and includes prohead formation and several pathways for separate phage components. DNA is cut to size and packed into preformed capsids. Maturing phages are usually dispersed through the cell; some form regular arrays. Lysis.

\section{Biological Aspects}

Over 100 genera of eubacteria and archaebacteria.

\section{FAMILIES}

Phages with contractile tails

Phages with long, non-contractile tails

Phages with short tails
Myoviridae Siphoviridae Podoviridae 


\begin{tabular}{|lll|}
\hline FAMILY & $\begin{array}{l}\text { PHAGES WITH } \\
\text { CONTRACTILE TAILS }\end{array}$ & MYOVIRIDAE \\
\hline
\end{tabular}

Compiled by H.-W. Ackermann

\section{Main Characteristics}

Tail is contractile, long (80-455 $\mathrm{nm}$ ) and complex, consisting of a central tube and a contractile sheath separated from the head by a neck. Contraction seems to require ATP. Relatively large capsids.

\begin{tabular}{lcl}
\hline \hline GENUS & - & - \\
\hline TYPE SPECIES & COLIPHAGE T4 GROUP & - \\
\hline
\end{tabular}

\section{Properties of The Virus Particle}

Morphology Elongated head of about $111 \times 78 \mathrm{~nm} ; 152$ capsomers $(\mathrm{T}=$ 13). Tail of $113 \times 16 \mathrm{~nm}$; provided with a collar, base plate, 6 short spikes and 6 long fibers.

Physicochemical $\mathrm{MW} \approx 210 \times 10^{6} ; \mathrm{S}_{20 \mathrm{w}} \approx 1,030$; buoyant density in $\mathrm{CsCl}$ properties $\quad=1.51 \mathrm{~g} / \mathrm{cm}^{3}$. Infectivity is ether- and chloroformresistant.

Nucleic acid One molecule of linear dsDNA; MW $\approx 120 \times 10^{6} ; 48 \%$ by weight of particle; contains hydroxymethyl-cytosine instead of thymine; $\mathrm{G}+\mathrm{C}=35 \%$; contains glucose. DNA is circularly permuted and terminally redundant. $150-160$ genes.

Protein At least 42 polypeptides with MW $=8-155 \times 10^{3} ; 1,600$ 2,000 copies of major capsid protein $\left(\mathrm{MW} \approx 43 \times 10^{3}\right) ; 3$ proteins are located inside the head. Various enzymes are present, e.g. dehydrofolate reductase, thymidylate synthetase.

Other constituents ATP, folate and polyamines.

\section{REPLICATION}

Adsorption site is cell wall; virulent infection. Host chromosome breaks down and viral DNA replicates as concatemer, giving rise to forked replicative intermediates. Heads, tails, and tail fibers are assembled by 3 different pathways. Morphologically aberrant particles are frequent. 


\section{Biological ASPECTS}

Host range Enterobacteria.

\section{OTHER MeMbERS}

T2, T4, T6, C16, DdVI, PST, SMB, SMP2, $\alpha 1,3,3 \mathrm{~T}+$, $9 / 0,11 \mathrm{~F}, 50,66 \mathrm{~F}, 5845,8893$ and about 70 others.

Other members of the family include the following phages listed by host genus or group:

Actinomycetes: SK1, 108/106

Aeromonas: Aeh2, 29, 37, 43, 44RR2.8t, 51, 59.1

Agrobacterium: PIIBNV6

Alcaligenes: A6

Bacillus: G, MP13, PBS1, SP3, SP8, SP10, SP15, SP50, SPy-2, SST

Clostridium: $\mathrm{HM} 3, \mathrm{CE} \beta$

Coryneforms: A19

Cyanobacteria: AS-1, N1, S-6(L)

Enterobacteria: Beccles, FC3-9, K19, Mu, O1, P1, P2, Vil, $\phi 92,121,16-19,9266$

Lactobacillus: fri, hv, hw, 222a

Listeria: 4211

Mollicutes: $\mathrm{Br} 1$

Mycobacterium: I3

Pasteurella: AU

Pseudomonas: PB-1, PP8, PS17, $\phi \mathrm{KZ}, \phi \mathrm{W}-14, \phi 1,12 \mathrm{~S}$

Rhizobium: $\mathrm{CM}_{1}, \mathrm{CT} 4, \mathrm{~m}, \mathrm{WT} 1, \phi$ gal-1-R

Staphylococcus: Twort

Xanthomonas: XP5

Vibrio: kappa, nt-1, X29, VP1, 06N-22P, II

Derivation of Name

myo: from Greek mys, myos, 'muscle', relating to contractile tail

\section{REFERENCES}

Ackermann, H.-W.; DuBow, M.S.: Viruses of Prokaryotes, Vol. II, pp. 1-161 (CRC Press, Boca Raton, Fl., 1978). 


\section{Main ChaRACTERISTICS}

Tail is noncontractile, long (64?-570 nm).

\begin{tabular}{lll}
\hline \hline GENUS & - & - \\
\hline TYPE SPECIES & COLIPHAGE $\lambda$ GROUP & - \\
\hline
\end{tabular}

Properties of the Virus Particle

Morphology Isometric head of about $60 \mathrm{~nm}$ in diameter; 72 capsomers $(\mathrm{T}=7)$. Flexible tail of $150 \times 8 \mathrm{~nm}$ with short terminal and subterminal tail fibres.

Physicochemical $\mathrm{MW} \approx 60 \times 10^{6} ; \mathrm{S}_{20 \mathrm{w}}=388$; buoyant density in $\mathrm{CsCl}=$ properties $1.50 \mathrm{~g} / \mathrm{cm}^{3}$. Infectivity is ether-resistant.

Nucleic acid One molecule of linear dsDNA; MW $\approx 33 \times 10^{6} ; 54 \%$ by weight of particle; $\mathrm{G}+\mathrm{C}=52 \%$; cohesive ends. About 50 genes.

Protein

Nine structural proteins; MWs $=17-130 \times 10^{3} ;$ about 420 copies of major capsid protein (MW $=38 \times 10^{3}$ ).

\section{REPLICATION}

Adsorption site is cell wall. Temperate infection; infecting DNA circularizes and integrates into host genome. Bidirectional replication as $\theta$ ring is followed by unidirectional replication via rolling-circle mechanism. No breakdown of host DNA. Heads and tails assemble by 2 pathways.

\section{Biological ASPECTS}

Host range Enterobacteria.

\section{OTHER MEMBERS}

HK97, HK022, PA-2, $\phi D 328, \phi 80$ 


\section{Possible members}

\section{$\mathrm{T} 1$}

Other members of family include the following phages, listed by host genus or group, which probably represent as much species:

Actinomycetes: A1-Dat, Bir, $\mathrm{M}_{1}, \mathrm{MSP} 8, \mathrm{P}-\mathrm{a}-1, \mathrm{R}_{1}, \mathrm{R}_{2}$, SV2, VP5, $\phi$ C, $\phi 31 \mathrm{C}, \phi \mathrm{UW} 21, \phi 115-\mathrm{A}, \phi 150-\mathrm{A}, 119$ Agrobacterium PS8, PT11, $\psi$ Alcaligenes: A5/A6, 8764

Bacillus: BLE, IPy-1, MP15, mor1, PBP1, SPP1, SP $\beta$, type F, $\alpha, \phi 105,1 \mathrm{~A}$, II

Clostridium: F1, HM7

Coryneforms: A, Arp, BL3, CONX, MT, $\beta, \phi A 8010$

Cyanobacteria: S-2L, S-4L

Enterobacteria: H-19J, Jersey, ZG/3A, T5, ViII, $\beta 4, \chi$

Lactobacillus: 1b6, PL-1, y5, фFSW, 223

Lactococcus: BJ5-T, c2, P087, P107, P335, 936, 949, 1358,1483

Leuconostoc: pro2

Listeria: H387, 2389, 2671, 2685

Micrococcus: N1, N5

Mycobacterium: lacticola, Leo, R1-Myb

Pasteurella: C-2, 32

Pseudomonas: D3, Kf1, M6, PS4, SD1

Rhizobium: NM1, NT2, ф2037/1, 5, 7-7-7, 16-2-12, 317

Staphylococcus: 3A, B11-M15, 77, 107, 187, 2848A

Streptococcus: A25, PE1, VD13, 13,24

Vibrio: VP3, VP5, VP11, $\alpha 3 a$, OXN-52P, IV

\section{Derivation of sipho: from Greek siphon, 'tube'}

Name

\section{REFERENCES}

Ackermann, H.-W.; DuBow, M.S.: Viruses of Prokaryotes, Vol. II, pp. 1-161 (CRC Press, Boca Raton, Fl., 1987).

Jarvis, A.W.; Fitzgerald, G.F.; Mata, M.; Mercenier, A.; Neve, H.; Powell, I.B.; Ronda, C.; Saxelin, M.; Teuber, M.: Type species and type phages of lactococcal bacteriophages. Intervirology (in press). 


\section{MAIN ChaRACTERISTICS}

Tail is short (about $20 \mathrm{~nm}$ ) and noncontractile.

\begin{tabular}{l}
\hline \hline GENUS \\
\hline TYPE SPECIES \\
\hline Morphology \\
$\begin{array}{l}\text { Physicochemical } \\
\text { properties }\end{array}$
\end{tabular}
properties

Nucleic acid

\section{Protein}

Host range
COLIPHAGE T7 GROUP

\section{Properties of the Virus Particle}

Isometric head of about $60 \mathrm{~nm}$ diameter; 72 capsomers (T $=7$ ). Short tail of $17 \times 8 \mathrm{~nm}$ with 6 short fibers.

$\mathrm{MW} \approx 48 \times 10^{6} ; \mathrm{S}_{20 \mathrm{w}}=507$; buoyant density in $\mathrm{CsCl}=$ $1.50 \mathrm{~g} / \mathrm{cm}^{3}$. Infectivity is ether- and chloroform-resistant.

One molecule of linear dsDNA; MW $\approx 25 \times 10^{6} ; 51 \%$ by weight of particle; $\mathrm{G}+\mathrm{C}=50 \%$ and is non-permuted and terminally redundant. 40-50 genes.

About 12 proteins, $\mathrm{MW} \approx 14-150 \times 10^{3}$; about 450 copies of major capsid protein $\left(\mathrm{MW}=38 \times 10^{3}\right) ; 1$ or 2 proteins are located inside the head.

\section{REPLICATION}

Adsorption site is cell wall. Virulent infection. Host chromosome breaks down and viral DNA replicates as concatemer.

\section{Biological Aspects}

Enterobacteria.

\section{OTHER MEMBERS}

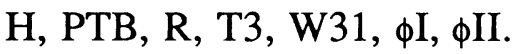

Other members of the family include the following phages, listed by host genus or group, which probably represent a number of different species:

Actinomycetes: AV-1, Ta 1,114

Aeromonas: AA-1

Agrobacterium: PIIBNV6-C 
Bacillus: GA-1, $\$ 29$

Brucella:. Tb

Clostridium: HM2

Coryneforms: AN25S-1, 7/26

Cyanobacteria: AC-1, A-4(L), SM-1, LPP-1

Enterobacteria: Esc-7-11, N4, P22, sd, $\Omega 8,7-11$, $7480 \mathrm{~b}$

Lactococcus: KSY1, P034

Mollicutes: C3, L3

Mycobacterium: $\phi 17$

Pasteurella: 22

Pseudomonas: F116, gh-1

Rhizobium: $\phi 2042,2$

Staphylococcus: 44AHJD

Streptococcus: Cp-1, Cvir, H39, 2BV, 182

Xanthomonas: RR66

Vibrio: OXN-100P, 4996, I, III

Derivation of podo: from Greek pous, podos, 'foot', for short tail Name

\section{REFERENCES}

Ackermann, H.-W.; DuBow, M.S.: Viruses of Prokaryotes, Vol. II, pp. 1-161 (CRC Press, Boca Raton, Fl., 1987).

Jarvis, A.W.; Fitzgerald, G.F.; Mata, M.; Mercenier, A.; Neve, H.; Powell, I.B.; Ronda, C.; Saxelin, M.; Teuber, M.: Type species and type phages in lactococcal bacteriophages. Intervirology (in press). 


\section{Morphology \\ Physicochemical properties}

Nucleic acid

Protein

\section{Lipid}

Carbohydrate

Polyamines

Antigenic properties

\section{Properties of the Virus Particle}

Nonenveloped isometric particles, $18-22 \mathrm{~nm}$ in diameter, with icosahedral symmetry.

$\mathrm{MW}=5.5-6.2 \times 10^{6} ; \mathrm{S}_{20 \mathrm{w}}=110-122 ;$ buoyant density $=$ $1.39-1.42 \mathrm{~g} / \mathrm{cm}^{3}$ in $\mathrm{CsCl}$. Infectious particles with buoyant densities near $1.45 \mathrm{~g} / \mathrm{cm}^{3}$ may represent conformational variants or precursors to the mature particles. The mature particle is stable in the presence of lipid solvents, at $\mathrm{pH} 3-9$, and in most species at $56{ }^{\circ} \mathrm{C}$ for at least $60 \mathrm{~min}$.

Single molecule of ssDNA of MW $=1.5-2.0 \times 10^{6} ; \mathrm{G}+\mathrm{C}$ $=41-53 \%$. Members of the genus Parvovirus preferentially encapsidate single-stranded DNA of negative polarity. However, under as yet unknown conditions, the percentage of particles encapsidating the positive strand can vary from 1 to $50 \%$. In the genera Dependovirus and Densovirus complementary plus and minus strands are encapsidated with about equal frequency. After extraction the complementary strands may hybridize in vitro to form a double strand.

Three polypeptides, MW $=60-90 \times 10^{3}$, can usually be demonstrated in conventionally purified mature virions of the genera Parvovirus and Dependovirus. Probably all are derived from a common sequence. Densoviruses were shown to have four structural polypeptides. $60-72$ protein molecules account for $63-81 \%$ of the weight of the virions. Enzymes are probably lacking.

None reported.

None reported.

Spermidine, spermine, and putrescine have been demonstrated in mature Densovirus particles.

The polypeptides of the virion are immunologically distinguishable; they are, however, antigenically related. In general, antisera to polypeptides do not show neutralization or react with whole virion using HI, complement-fixation or immune electrophoresis. For the genus Parvovirus hemagglutinating, complement-fixing, 
and neutralizing antigens are type specific without crossreaction. Cross-reactions, however, have been observed in the fluorescent antibody test for several parvoviruses. This may be due to the existence of at least one nonstructural, highly conserved antigen. Dependoviruses share a similar common antigen and common antigens were also demonstrated for Densoviruses by fluorescent antibody staining and by immunodiffusion.

\section{REPLICATION}

Viral replication takes place in the nucleus where viral proteins in the form of empty capsid structures and progeny infectious virions accumulate. For multiplication, members of the genus Parvovirus require one or more cellular functions generated during the $S$ phase of the cellular division cycle. Members of the genus Dependovirus require helper virus coinfection (adenoviruses, herpesviruses) for efficient replication, but recent data suggest that cells may become at least partially competent in independent replication of the viruses during a narrow window (presumably within the $S$ phase) of the cell cycle.

\section{GENERA}

Parvovirus group

Adeno-associated virus group

Insect parvovirus group

Parvovirus

Dependovirus

Densovirus

\begin{tabular}{llc}
\hline \hline GENUS & PARVOVIRUS GROUP & PARVOVIRUS \\
\hline TYPE SPECIES & MINUTE VIRUS OF MICE (MVM) & - \\
\hline
\end{tabular}

\section{Properties of The Virus Particle}

Nucleic acid

The linear molecule of ssDNA has hairpin structures at both the 5'- and 3'-ends (3'-terminal hairpin: 115-116 nucleotides, 5'-palindromic structure: 200-242 nucleotides). In most members of the genus all mature virions contain minus-strand DNA. In other members, plus-strand DNA is also encapsidated in variable (1-50\%) proportions.

Effect on cells Characteristic CPE induced by many viruses during replication in cell culture. Many species contain a hemagglutinin which has different activities for a variety of red blood cells. 


\section{REPLICATION}

The virus multiplies in the nucleus, and replication is dependent upon certain helper functions provided by the host cell. In consequence, viruses multiply preferentially in actively dividing cells.

\section{Biological Aspects}

Host range In nature: cat, cattle, chicken, dog, goose, man, mink, mouse, pig, rabbit, raccoon, rat. Under experimental conditions the host range may be extended to homologous or closely related hosts. Rodent viruses and LuIII also replicate in Syrian hamsters.

Transmission Transplacental transmission has been detected for a number of species. Vertical passage by ova is indicated for goose parvovirus. Transmission by mechanical vectors is also possible.

\section{OTHER MEMBERS}

Aleutian mink disease parvovirus

B19

Bovine parvovirus

Feline parvovirus

Species host range variants

FPLV (feline panleukopenia virus)

MEV (mink enteritis virus)

CPV (canine parvovirus)

RPV (raccoon parvovirus)

Goose parvovirus

\section{H-1}

Lapine parvovirus

LuIII

Porcine parvovirus

Rat virus

RT

TVX

\section{Probable members}

Chicken parvovirus

HB

Minute of canines (MVC)

RA-1 


\begin{tabular}{llc}
\hline \hline GENUS & ADENO-ASSOCIATED & DEPENDOVIRUS \\
& VIRUS GROUP & \\
\hline TYPE SPECIES & ADENO-ASSOCIATED & - \\
& VIRUS TYPE 1 & \\
\hline
\end{tabular}

\section{Properties of the Virus Particle}

Nucleic acid Mature virions contain either positive or negative DNA strands. The DNA molecules contain inverted terminal repeats of 145 nucleotides, the first 125 of which form a palindromic sequence. Upon extraction, the complementary DNA strands usually form a double strand.

Antigenic properties

Host range

Transmission
All AAVs share a common antigen demonstrable by fluorescent antibody staining.

\section{REPLICATION}

Efficient replication is dependent upon helper adenoviruses or herpesviruses. Under certain conditions (presence of mutagens, synchronization with hydroxyurea), replication can also be detected in the absence of helper viruses.

\section{Biological ASPeCts}

Cattle, chicken, dog, horse, man, monkey, sheep.

Transplacental transmission has been observed for AAV-1 and vertical transmission has been reported for Avian AAV.

\section{OTHER MEMBERS}

AAV type 2

AAV type 3

AAV type 4

AAV type 5

Avian AAV

Bovine AAV

Canine AAV

Probable members

Equine AAV

Ovine AAV 


\begin{tabular}{llc}
\hline \hline GENUS & INSECT PARVOVIRUS GROUP & DENSOVIRUS \\
\hline TYPE SPECIES & GALLERIA DENSOVIRUS & - \\
\hline
\end{tabular}

\section{Properties of The Virus Particle}

Nucleic acid Single strands in virions are either positive or negative, are complementary, and come together when isolated in vitro to form adouble strand.

\section{REPLICATION}

Multiply in most of the tissues of larvae, nymphs, and adults without helper viruses. Cellular changes consist of hypertrophy of the nucleus with accumulation of virions to form dense, voluminous intranuclear masses.

\section{Biological ASPECTS}

Host range Diptera, Lepidoptera, and Orthoptera. There is evidence that densovirus-like viruses also infect and multiply in crabs and shrimps.

\section{OTHER MEMBERS}

Junonia Densovirus

Agraulis Densovirus

Bombyx Densovirus

\section{Probable members}

Acheta Densovirus

Aedes Densovirus

Diatraea Densovirus

Euxoa Densovirus

Leucorrhinia Densovirus

Periplanata Densovirus

Pieris Densovirus

Sibine Densovirus

Simulium Densovirus

\section{Possible members}

PC 84 (parvo-like virus from the crab Carcinus mediterraneus)

Hepatopancreatic parvo-like virus of penaeid shrimps 
Derivation of parvo: from Latin parvus, "small"

Name adeno: from Greek aden, adenos, "gland" dependo: from Latin dependere, "depending" denso: from Latin densus, "thick, compact"

\section{REFERENCES}

Berns, K.I.: The Parvoviruses (Plenum Press, New York, London, 1984).

Kurstak, E.: Small DNA densonucleosis virus (DNV). Adv. Virus Res. 17:207-241 (1972).

Lightner, D.V.; Redman, R.M.: A parvo-like virus disease of Penaeid shrimp. J. Invertebr. Pathol. 45:47-53 (1985).

Mari, J.; Bonami, J.-R.: PC84, a parvo-like virus from the crab Carcinus mediterraneus: pathological aspects, ultrastructure of the agent, and first biochemical characterization. J. Invertebr. Pathol. 51:145-156 (1988).

Pattison, J.R.: Parvoviruses and human disease (CRC Press, Boca Raton, Fl., 1988).

Siegl, G: The parvoviruses. Virology Monographs, Vol. 15 (Springer, Wien, New York, 1976).

Siegl, G.; Bates, R.C.; Berns, K.I.; Carter, B.J.; Kelly, D.C.; Kurstak, E.; Tattersall, P.: Characteristics and Taxonomy of Parvoviridae. Intervirology 23:61-73 (1985).

Tijssen, P.: Handbook of Parvoviruses, Vols. I and II. (CRC Press, Boca Raton, Fl., 1990).

Tijssen, P.; Kurstak, E.; Su, T.M.; Garzon, S.: Proc. Colloqu. Invertebr. Pathol., Brighton, England, p. 148 (1982).

Ward, D.; Tattersall, P.: Replication of mammalian parvoviruses. (Cold Spring Harbor Press, Cold Spring Harbor, 1978). 
GROUP

Morphology

Physicochemical properties

Nucleic acid

Protein

Lipid

Carbohydrate

Antigenic properties

Host range

Transmission

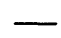

GEMINIVIRUS

Revised by R. Hull, J. Stanley \& R.W. Briddon

Properties of the Virus Particle

Geminate particles, $\approx 18 \times 30 \mathrm{~nm}$, consisting of two incomplete icosahedra with $\mathrm{T}=1$ surface lattice with a total of 22 capsomers.

$S_{20 w} \approx 70$ (for particle pairs).

One (subgroup I and II) or two (subgroup III) molecules of single-stranded DNA, MW = 7-8 x $10^{5}(2.5-3.0 \mathrm{~kb})$. Open reading frames occur on both the viral strand and its complement.

Single coat polypeptide, $\mathrm{MW}=27-34 \times 10^{3}$.

None reported.

None reported.

Efficient immunogens. Single precipitin line in geldiffusion. Some serological relationship between members of subgroup III.

\section{REPLICATION}

Genome is replicated via dsDNA which can be isolated from infected tissues. Virus particles accumulate in nucleus, producing large aggregates.

\section{Biological ASPECTS}

Members of the subgroup I are confined primarily to the Graminae. Members of subgroup II and III infect dicotyledonous plants. Individual members tend to have narrow host-ranges except BCTV which has a wide host range.

Transmitted naturally by leafhoppers (subgroup I and II) or the whitefly Bemisia tabaci (subgroup III) in a persistent manner. Some members are also mechanically transmissible, usually with difficulty. 


\section{HOMOLOGIES BETWEEN SUBGROUPS}

DNA A of the viruses in subgroup III bear some sequence similarities and possible structural and functional similarities to the DNA genome of viruses in subgroups I and II, suggesting a distant evolutionary relationship between the subgroups.

\begin{tabular}{lcc}
\hline \hline SUBGROUP I & - & - \\
\hline TYPE MEMBER & MAIZE STREAK VIRUS (MSV) (133) & - \\
\hline
\end{tabular}

\section{Properties of The Virus Particle}

Nucleic acid One molecule of circular single stranded DNA, MW $=7-8$ $\mathrm{x} 10^{5}(2.7-3.0 \mathrm{~kb})$. Open reading frames (putative genes) occur on both the viral strand and its complement. DNAs of five members (MSV, WDV, DSV, MiSV and CSMV) have been sequenced .

Protein

Antigenic properties

Host range

Transmission
Single coat polypeptide, $\mathrm{MW}=28-34 \times 10^{3}$.

Serological tests show lack of interrelationship among subgroup members.

\section{Biological Aspects}

Subgroup members have narrow host ranges limited to the Graminae.

Transmitted in nature by leafhoppers in a persistent manner. Not transmitted by mechanical inoculation. Some members have been transmitted by Agrobacteriummediated transfer using recombinant DNA methods (MSV, DSV and WDV).

\section{OTHER MEMBERS}

Chloris striate mosaic (221)

Digitaria streak

Miscanthus streak

Wheat dwarf

\section{Probable members}

Bajra streak

Bromus striate mosaic

Digitaria striate mosaic

Oat chlorotic stripe

Paspalum striate mosaic 


\begin{tabular}{lll}
\hline \hline SUBGROUP II & - & - \\
\hline TYPE MEMBER & $\begin{array}{l}\text { BEET CURLY TOP VIRUS } \\
\text { (BCTV)(210) }\end{array}$ & - \\
\hline
\end{tabular}

\section{Properties of The Virus Particle}

Nucleic acid One molecule of circular single stranded DNA, MW $=8 \mathrm{x}$ $10^{5}$ (2993 b). Open reading frames (putative genes) occur on both the viral strand and its complement. DNA of BCTV has been sequenced.

Protein

Antigenic properties

Host range

Transmission
Single coat polypeptide, $\mathrm{MW}=30 \times 10^{3}$.

Serological tests show distant relationship with most subgroup III members (BCTV and TPCTV and TLRV; BSDV and TYDV are closely related).

\section{Biological ASPECTS}

Subgroup member, BCTV, has a wide host range.

Transmitted in nature by leafhoppers in a persistent manner, except for TPCTV which is transmitted by treehopper. Transmitted with difficulty by mechanical inoculation. BCTV has been transmitted by Agrobacterium-mediated transfer using recombinant DNA methods.

\section{OTHER MEMBERS}

Tomato pseudo-curly top virus

Bean summer death virus

Tobacco yellow dwarf virus

Tomato leafroll virus

\begin{tabular}{lll}
\hline \hline SUBGROUP III & - & - \\
\hline TYPE MEMBER & $\begin{array}{l}\text { BEAN GOLDEN MOSAIC VIRUS } \\
\text { (BGMV) (192) }\end{array}$ & - \\
\hline
\end{tabular}

\section{Properties of the Virus Particle}

Nucleic acid Two molecules of circular single-stranded DNA, each MW $=7-8 \times 10^{5}(2.4-2.8 \mathrm{~kb})$. Open reading frames (putative genes) occur on both the viral strand and its complement. DNAs of six members (ACMV, BGMV, TGMV, TYLCV, AbMV and MYMV) have been sequenced.

Protein Single coat polypeptide, MW $=27-30 \times 10^{3}$. 
Antigenic properties

Host range

Transmission
Serological tests show interrelationships among some subgroup members.

\section{Biological Aspects}

Individual subgroup members generally have narrow host ranges, among dicotyledonous plants, but as a subgroup the viruses have hosts in a wide spectrum of higher plant families.

Transmitted in nature by the whitefly Bemisia tabaci in a persistent manner and experimentally, by mechanical inoculation.

\section{OTHER MEMBERS}

Abutilon mosaic virus

African cassava mosaic virus

Cotton leaf crumple virus

Euphorbia mosaic virus

Honeysuckle yellow vein mosaic virus

Horsegram yellow mosaic virus

Indian cassava mosaic virus

Jatropha mosaic virus

Limabean golden mosaic virus

Malvaceous chlorosis virus

Melon leaf curl virus

Mungbean yellow mosaic virus

Potato yellow mosaic virus

Rhynochosia mosaic virus

Squash leaf curl virus

Tigre disease virus

Tobacco leaf curl virus

Tomato golden mosaic virus

Tomato leaf curl virus

Tomato yellow dwarf virus

Tomato yellow leaf curl virus

Tomato yellow mosaic virus

Watermelon chlorotic stunt virus

Watermelon curly mottle virus

\section{Probable members}

Cotton leaf curl virus

Cowpea golden mosaic virus

Eggplant yellow mosaic virus

Eupatorium yellow vein virus

Lupin leaf curl virus

Solanum apical leaf curl virus

Soybean crinkle leaf virus

Wissadula mosaic virus 
Derivation

gemini: from Latin gemini, "twins", from characteristic of Name double particle.

\section{REFERENCES}

Davies, J.W.; Townsend, R.; Stanley, J.: The structure, expression, functions and possible exploitation of geminivirus genomes; In Hohn, T.; Schell, J. (eds.), Plant DNA Infectious Agents pp. 31-52 (Springer, Wien, New York, 1987).

Francki, R.I.B.; Milne, R.G.; Hatta, T.: Geminivirus group, In Atlas of Plant Viruses, Vol. I, pp. 33-46 (CRC Press, Boca Raton, Fl., 1985).

Goodman, R.M.: Geminiviruses. J. gen. Virol. 54:9-21 (1981).

Harrison, B.D.: Advances in geminivirus research. Annu. Rev. Phytopathol. 23:55-82 (1985).

Howarth, A.J.; Goodman, R.M.: Divergence and evolution of geminivirus genomes. J. Molec. Evol. 23:313-319 (1986).

Lazarowitz, S.G.: The molecular characterization of geminiviruses. Plant Mol. Biol. Reptr. 4: 177-192 (1987).

Roberts, I.M.; Robinson, D.J.; Harrison, B.D.: Serological relationships and genome homologies among geminiviruses. J. gen. Virol. 65:1723-1730 (1984).

Stanley, J.; Davies, J.W.: Structure and function of the DNA genome of Geminiviruses; In Davies, J.W. (ed.), Molecular Plant Virology, Replication and gene expression, Vol. II, pp 191-218 (CRC Press, Boca Raton, Fl., 1984).

Thomas, J.E.; Massalski, P.R.; Harrison, B.D.: Production of monoclonal antibodies to African cassava mosaic virus and differences in their reactivities with other whiteflytransmitted geminiviruses. J. gen. Virol. 67:2739-2748 (1986). 


\begin{tabular}{|lll|}
\hline FAMILY & $\begin{array}{l}\text { ISOMETRIC PHAGES } \\
\text { WITH SSDNA }\end{array}$ & MICROVIRIDAE \\
\hline
\end{tabular}

Revised by H.-W. Ackermann

Morphology Isometric, $25-27 \mathrm{~nm}$ in diameter. No envelope.

Nucleic acid One molecule of circular ssDNA, MW $=1.6-1.7 \times 10^{6}$.

Lipid None or not reported.

Carbohydrate None or not reported.

REPLICATION

Phage DNA is converted to circular RF. Virulent, lysis.

\section{GENERA}

$\phi X$-type phages

SpV4-type phages

MAC-1-type phages (proposed)
Microvirus

Spiromicrovirus

\begin{tabular}{llc}
\hline \hline GENUS & $\phi X$ PHAGE GROUP & MICROVIRUS \\
\hline TYPE SPECIES & COLI PHAGE $\phi X 174$ GROUP & - \\
\hline
\end{tabular}

\section{Properties of The Virus Particle}

Morphology Icosahedral, about $27 \mathrm{~nm}$ in diameter; 12 conspicuous capsomers $(T=1)$ and knob-like spikes on vertices. No envelope.

Physicochemical $\mathrm{MW}=6.7 \times 10^{6} ; \mathrm{S}_{20 \mathrm{w}}=114$; buoyant density in $\mathrm{CsCl}=$ properties $\quad 1.41 \mathrm{~g} / \mathrm{cm}^{3}$. Infectivity is chloroform-resistant.

Nucleic acid Positive-sense ssDNA; MW $\approx 1.7 \times 10^{6}$, about $26 \%$ by weight of particle; $\mathrm{G}+\mathrm{C}=44 \% ; 11$ partly overlapping genes.

Protein

60 molecules of capsid protein $\left(\mathrm{MW}=50 \times 10^{3}\right) ; 3$ other proteins.

Lipid None.

Carbohydrate None. 


\section{REPLICATION}

Adsorption to cell wall. Progeny ssDNA is generated by displacement from RF DNA. Three sections of the genome code for three different proteins in different reading frames. Capsid is assembled in nucleoplasm around scaffolding protein. No inclusion bodies.

\section{Biological ASPECTS}

Host range Enterobacteria.

\section{OTHER MEMBERS}

$\mathrm{BE} / 1, \mathrm{~d} \phi 3, \mathrm{~d} \phi 4, \mathrm{~d} \phi 5, \mathrm{G} 4, \mathrm{G} 6, \mathrm{G} 13, \mathrm{G} 14,1 \phi 1,1 \phi 3,1 \phi 7$, 1 $\$ 9, \mathrm{M} 20, \mathrm{St}-1, \mathrm{~S} 13, \mathrm{WA} / 1, \mathrm{WF} / 1, \mathrm{WW} / 1, \mathrm{U} 3,2 \mathrm{D} / 13$, $\alpha 3, \alpha 10, \delta 1, \zeta 3, \eta 8,06, \phi \mathrm{A}, \phi \mathrm{R}$ (several species)

\begin{tabular}{llc}
\hline \hline GENUS & SPV4-TYPE PHAGES & SPIROMICROVIRUS \\
\hline TYPE SPECIES & SPIROPLASMA PHAGE & - \\
& SPV4 \\
\hline
\end{tabular}

\section{Properties of the Virus Particle}

Morphology Isometric, about $27 \mathrm{~nm}$ in diameter, no envelope.

Physiochemical Buoyant density in $\mathrm{CsCl}=1.40 \mathrm{~g} / \mathrm{cm}^{3}$. Infectivity is properties ether-, chloroform-, and detergent-resistant.

Nucleic Acid One molecule of circular ssDNA; MW $\approx 1.7 \times 10^{6}, \mathrm{G}+\mathrm{C}=$ $32 \%$, at least 9 partly overlapping genes.

Protein Single capsid protein of $64 \times 10^{3}$.

\section{Lipid Not known.}

Carbohydrate Not known.

Biological ASpects

Host range Spiroplasma. 


\begin{tabular}{lll}
\hline \hline POSSIBLE & MAC-1 TYPE PHAGES & - \\
GENUS & & - \\
\hline TYPE SPECIES & $\begin{array}{l}\text { BDELLOVIBRIO PHAGE } \\
\text { MAC-1 GROUP }\end{array}$ & - \\
\hline
\end{tabular}

\section{Properties of The Virus Particle}

Morphology Isometric, about $25 \mathrm{~nm}$ diameter, no envelope.

Physiochemical $\quad S_{20 \mathrm{w}}=94$, buoyant density in $\mathrm{CsCl}=1.36 \mathrm{~g} / \mathrm{cm}^{3}$. properties

Nucleic Acid One molecule of circular ssDNA; MW $\approx 1.6 \times 10^{6}$.

Protein Single capsid protein of $64 \times 10^{3}$.

Lipid Not known.

Carbohydrate Not known.

Biological Aspects

Host range Bdellovibrio.

MEMBERS

MAC-1', MAC-2, MAC-4, MAC-4', MAC-5, MAC-7.

Derivation of micro: from Greek mikros, "small"

Name

\section{REFERENCES}

Ackermann, H.-W.; DuBow, M.S.: Viruses of Prokaryotes, Vol. II, pp. 171-218 (CRC Press, Boca Raton, Fl., 1987).

Denhardt, D.T.: The isometric single-stranded DNA phages. In Fraenkel-Conrat, H.; Wagner, R.R. (eds.), Comprehensive Virology, Vol. 7, pp. 1-104 (Plenum Press, New York, 1977).

Maniloff, J.: Mycoplasma Viruses. CRC Crit. Rev. Microbiol. 15: 339-389 (1988).

Roberts, R.C.; Keefer, M.A.; Ranu, R.S.: Characterization of Bdellovibrio bacteriovorus bacteriophage MAC-1. J. Gen. Microbiol. 133: 3065-3070 (1987). 


\begin{tabular}{|lll}
\hline FAMILY ROD-SHAPED PHAGES & INOVIRIDAE
\end{tabular}

Morphology

Revised by H.-W. Ackermann \& J. Van Duin

\section{Properties of the Virus Particle}

Long or short helical rods, which are or seem to be tubules. DNA is located in particle centre. Particles of abnormal length are frequent. No envelope.

Physicochemical Infectivity is chloroform-sensitive and heat-resistant. properties

Nucleic acid One molecule of circular positive-sense ssDNA.

\section{REPLICATION}

Infecting viral DNA is converted into a dsRF which replicates in a semiconservative way. No inclusion bodies. Phages extruded through host membranes; no lysis, host survives and enters a carrier state.

\section{GENERA}

Filamentous phages

Rod-shaped phages

Inovirus

Plectrovirus

\begin{tabular}{llc}
\hline \hline GENUS & FILAMENTOUS PHAGES & INOVIRUS \\
\hline TYPE SPECIES & COLIPHAGE fd GROUP & - \\
\hline
\end{tabular}

\section{Properties of The Virus PaRTiCle}

Morphology Usually flexible rods, $760-1,950 \mathrm{~nm}$ long x 6-8 $\mathrm{nm}$ in diameter.

Physicochemical $\mathrm{MW}=12-23 \times 10^{6} ; \mathrm{S}_{20 \mathrm{w}}=41-45$; buoyant density in properties $\mathrm{CsCl}=1.3 \mathrm{~g} / \mathrm{cm}^{3}$. Infectivity is sensitive to sonication; ether sensitivity is variable.

Nucleic acid $\quad \mathrm{MW}=1.9-3.0 \times 10^{6} ; 6-21 \%$ by weight of particle; $\mathrm{G}+\mathrm{C}=$ 40-60\%. So far as known, 9 partly overlapping genes.

Protein One major coat protein $\left(\mathrm{MW} \approx 5 \times 10^{3}\right)$ and 3 or 4 copies of adsorption protein $\left(\mathrm{MW} \approx 65-70 \times 10^{3}\right)$. Coat proteins appear to lack cysteine and histidine.

Lipid None.

Carbohydrate None. 


\section{REPLICATION}

Particles adsorb slowly to pili or poles (?) of bacteria and enter the cells; many plasmid specificities. Progeny viral ssDNA is produced by displacement from RF DNA. Overlapping genes code for different proteins in different reading frames. Mature phages are assembled at the plasma membrane as the particles leave the cell. Some phages are temperate.

\section{Biological Aspects}

Host range Enterobacteria, Pseudomonas, Vibrio, Xanthomonas.

\section{OTHER MEMBERS}

The genus probably includes $10-11$ species differentiated by particle length, host range, antigenic properties and chemical composition.

a. Phages of enterbacteria:

- fd group: AE2, Ec9, f1, HR, M13, ZG/2, ZJ/2, $\delta \mathrm{A}$

- other: C-2, If1, If2, Ike, I2-2, PR64FS, SF, tf-1, X

b. Pf1, Pf2, Pf3 (Pseudomonas).

c. Cf, Cf1t, Xf, Xf2 (Xanthomonas).

d. v6, Vf12, Vf33 (Vibrio).

\begin{tabular}{llc}
\hline \hline GENUS & ROD-SHAPED PHAGES & PLECTROVIRUS \\
\hline TYPE SPECIES & ACHOLEPLASMA PHAGE & - \\
\hline & L51 GROUP \\
\hline
\end{tabular}

\section{Properties of The Virus Particle}

Morphology Short, straight rods, $\approx 85$ to $280 \mathrm{~nm}$ long $\times 14 \mathrm{~nm}$ in diameter; one round end; may be derived from icosahedra $(\mathrm{T}=1)$.

Physicochemical Buoyant density in $\mathrm{CsCl} \approx 1.38 \mathrm{~g} / \mathrm{cm}^{3}$. Infectivity is properties ether- and detergent-resistant.

Nucleic acid $\quad \mathrm{MW}=2.5-5.2 \times 10^{6}(4.4-8.5 \mathrm{~kb})$.

Protein Four proteins (MW $=19-70 \times 10^{3}$, shown in L51 only).

Lipid None reported.




\section{Carbohydrate None reported.}

\section{REPLICATION}

Infecting viral DNA is converted into a dsRF which replicates in a semiconservative way. No inclusion bodies. Phages extruded through host membranes, no lysis, host survives and enters a carrier state.

\section{Biological ASPECtS}

Host range

Acholeplasma and Spiroplasma

\section{OTHER MEMBERS}

a. MV-L1, MVG51, 0c1r, 10tur, others (over 50 isolates, Acholeplasma, $85 \times 14 \mathrm{~nm}$ ).

b. SV1 (Spiroplasma, 230-280 x 10-15 nm).

Derivation of ino: from Greek is, inos, 'muscle'

Name

\section{REFERENCES}

Ackermann, H.-W.; DuBow, M.S.: Viruses of Prokaryotes, Vol. II, pp. 171-218 (CRC Press, Boca Raton, Fl., 1987).

Kuo, T.-T.; Lin, Y.-H.; Huang, C.-M.; Chang, S.-F.; Dai, H.; Feng, T.-Y.: The lysogenic cycle of the filamentous phage Cflt from Xanthomonas campestris pv. citri. Virology 156: 305-312 (1987).

Maniloff, J.: Mycoplasma viruses. CRC Crit. Rev. Microbiol. 15: 339-389 (1988).

Ray, D.S.: Replication of filamentous bacteriophages; In Fraenkel-Conrat, H.; Wagner, R.R. (eds.), Comprehensive Virology, Vol. 7, pp. 105-178 (Plenum Press, New York, 1977).

Zinder, N.D.; Horiuchi, K.: Multiregulatory element of filamentous bacteriophages. Microbiol. Rev. 49: 101-106 (1985). 


\begin{tabular}{|lll}
\hline FAMILY $\quad \phi 6$ PHAGE GROUP & CYSTOVIRIDAE \\
\hline
\end{tabular}

Revised by H.-W. Ackermann

\begin{tabular}{llc}
\hline \hline GENUS & $\phi 6$ PHAGE GROUP & CYSTOVIRUS \\
\hline TYPE SPECIES & PSEUDOMONAS PHAGE $\phi 6$ & - \\
\hline
\end{tabular}

\section{Properties of the Virus Particle}

Morphology Isometric, about $75 \mathrm{~nm}$ in diameter; flexible envelope and dodecahedral capsid of $60 \mathrm{~nm}$ diameter.

Physicochemical $\mathrm{MW} \approx 90 \times 10^{6} ; \mathrm{S}_{20 \mathrm{w}}=446$; buoyant density in $\mathrm{CsCl}=$ properties

$1.27 \mathrm{~g} / \mathrm{cm}^{3}$. Infectivity is ether-, chloroform-, and detergent-sensitive.

Nucleic acid Three molecules of linear dsRNA; total MW $\approx 10.4(2.3$, 3.1 and 5.0$) \times 10^{6}$ about $11 \%$ by weight of particle; $\mathrm{G}+\mathrm{C}$ $=58 \%$.

Protein Eleven polypeptides with total MW $=364 \times 10^{3}$ (range 6$\left.82 \times 10^{3}\right)$; transcriptase present.

Lipid Located in the envelope, constitutes about $20 \%$ of particle; over $90 \%$ is phospholipid.

\section{Carbohydrate Not known.}

\section{REPLICATION}

Adsorption to sides of pili. Capsid enters periplasmic space. Virion-dependent transcriptase synthesizes positive strands. Replication is semi-conservative. Capsids are assembled in nucleoplasm and filled by RNA and transcriptase. Virulent, lysis.

\section{Biological ASPECTS}

\section{Host range Pseudomonas}

\section{OTHER MEMBERS}

None. 


\section{Derivation of tecti: from Greek kystis, 'bladder, sack' \\ Name}

\section{REFERENCES}

Ackermann, H.-W.; DuBow, M.S.: Viruses of Prokaryotes, Vol. II, pp 171-218 (CRC Press, Boca Raton, Fl., 1987)

Mindich, L.: Bacteriophage $\phi 6:$ A unique virus having a lipid-containing membrane and a genome composed of three dsRNA segments. Adv. Virus Res. 35:137-176 (1988). 
Morphology

\section{Properties of The Virus Particle}

Icosahedral particles with diameter $\approx 60-80 \mathrm{~nm}$; one or two outer protein coats and an inner protein coat; particle with the outer coat(s) removed is termed the core; transcriptase activity is associated with the core.

Physicochemical $\mathrm{MW} \approx 120 \times 10^{6}$; buoyant density in $\mathrm{CsCl}=1.36-1.39$ properties $\mathrm{g} / \mathrm{cm}^{3}$.

Nucleic acid

10-12 segments of linear dsRNA; MWs $=0.2-3.0 \times 10^{6}$. Total MW $=12-20 \times 10^{6}$. About $14-22 \%$ by weight of virus particle. Each RNA segment has one ORF encoding a protein requiring no further processing.

Protein

6-10 proteins in virus particle; MWs $=15-155 \times 10^{3}$ including transcriptase and messenger RNA capping enzymes.

Lipid None.

Carbohydrate Some proteins are glycosylated.

REPLICATION

In cytoplasm. Viroplasms in cytoplasm of infected cells, sometimes containing virus particles in paracrystalline arrays. Genetic recombination occurs very efficiently by genome segment reassortment.

\section{GENERA}

Reovirus subgroup

Orthoreovirus

-

Orbivirus

Coltivirus

$-$

Rotavirus

Cytoplasmic polyhedrosis virus group

Plant reovirus subgroup 1

Plant reovirus subgroup 2

Aquareovirus

Cypovirus

Phytoreovirus

Plant reovirus subgroup 3 (proposed) 


\begin{tabular}{llc}
\hline \hline GENUS & REOVIRUS SUBGROUP & ORTHOREOVIRUS \\
\hline TYPE SPECIES & REOVIRUS TYPE 1 & - \\
\hline
\end{tabular}

\section{Properties of The Virus Particle}

Morphology Particles $\approx 76 \mathrm{~nm}$ in diameter; cores $\approx 52 \mathrm{~nm}$ in diameter. The particle consists of an outer protein coat and core. Cores possess twelve spikes with 5-fold symmetry arranged icosahedrally through which genome segment transcripts are released.

Physicochemical properties

Nucleic acid

Protein

Antigenic properties

Host range

Transmission
$\mathrm{MW} \approx 130 \times 10^{6} ; \mathrm{S}_{20 \mathrm{w}} \approx 730$. Infectivity resistant to ether; relatively heat-stable; stable at $\mathrm{pH}$ 3.0.

10 segments of dsRNA with MWs $=0.5-2.7 \times 10^{6}$; total MW $=14-15 \times 10^{6}$; about $14 \%$ by weight of particle; $\mathrm{G}+\mathrm{C}$ $=44 \%$. Cores contain $\approx 44 \%$ RNA. Virus contains $\approx$ 3,000 oligoribonucleotides 2-20 nucleotides long. There is no sequence homology between the genomes of Orthoreovirus members and members of other genera.

Nine proteins with MW $=38-155 \times 10^{3} ; 86 \%$ of virus by weight. Nucleotide phosphohydrolase and capping enzymes present besides the transcriptase.

The type-specific antigen is protein $\sigma 1$; proteins $\lambda 2$ and $\sigma 3$ are group-specific antigens.

\section{REPLICATION}

Two nonstructural proteins are synthesized $(\mathrm{MW} \approx 41,000$ and 75,000 ). Transcriptase synthesizes positive strands. Later a presumably related replicase synthesizes negative strands, thus forming progeny dsRNA molecules.

\section{Biological Aspects}

Vertebrates only; man, monkeys, birds, cattle, bats. Experimentally in cells of most vertebrate species.

\section{Horizontal}

\section{OTHER MEMBERS}

Serotypes 1, 2 and 3 include strains isolated from man, monkeys, dogs and cattle. Avian strains share groupspecific antigens and are distantly related serologically to mammalian serotypes. Also Nelson Bay virus with properties intermediate between those of mammalian and avian orthoreoviruses. 


\begin{tabular}{lcc}
\hline \hline GENUS & - & ORBIVIRUS \\
\hline TYPE SPECIES & BLUETONGUE VIRUS & - \\
\hline
\end{tabular}

\section{Properties of the Virus Particle}

Morphology

Physicochemical properties

Nucleic acid

\section{Protein}

Antigenic properties

Host range

Transmission
Particles $65-80 \mathrm{~nm}$ in diameter. Outer capsid shells and cores have no projections, but exhibit 32 large ring-shaped capsomers which are visible when the outer shells are still present.

$\mathrm{MW} \approx 80 \times 10^{6} ; \mathrm{S}_{20 \mathrm{w}}=550$. Infectivity is lost at $\mathrm{pH}$ 3.0. Lipid solvents reduce infectivity $\approx 10$-fold.

10 segments with $\mathrm{MW}=0.5-2.8 \times 10^{6}$; total $\mathrm{MW} \approx 15 \mathrm{x}$ $10^{6} ; 20 \%$ by weight of virus; $\mathrm{G}+\mathrm{C}=42-44 \%$.

Seven proteins with MW $=35-150 \times 10^{3} ; 80 \%$ by weight. Removal of outer shell required for activation of the RNAdependent RNA polymerase. Major core proteins are VP3 and VP7 (MW $\approx 103$ and $38 \times 10^{3}$, respectively); the latter is the major component of capsomeres on the core surface. Cores also contain VP1, VP4 and VP6. Outer capsid layer contains VP2 $\left(\mathrm{MW} \approx 111 \times 10^{3}\right)$ and VP5 $(\mathrm{MW} \approx 59 \mathrm{x}$ $10^{3}$ ). Three non-structural proteins NS1-3 have MW $\approx$ $64.4,41$ and $25.6 \times 10^{3}$; NS2 is a phosphoprotein.

Protein VP2 is main antigenic determinant for neutralization, although VP5 is also involved in type specificity. VP7 is the main group-specific antigen.

\section{REPLICATION}

Removal of outer capsid is required for activation of the RNA-dependent RNA polymerase. Replication takes place in cytoplasmic viroplasms. There are 3 nonstructural proteins, NS1-3 with MWs $\approx 64.4,41$ and $25.6 \times 10^{3}$. Morphogenesis is accompanied by formation of regularly structured filaments and tubules. The latter, at least, consist of NS1.

\section{BIOLOGICAL ASPECTS}

Insects and other arthropods; vertebrate hosts include man, horses, monkeys, rabbits, cattle, deer, suckling mice.

Vectors; Culicoides, mosquitoes, phlebotomines and ticks. 


\section{OTHER MEMBERS}

There are 12 serological groups in the genus Orbivirus (number of serotypes and vectors are indicated where known):

African horse sickness

Bluetongue

Changuinola

$\begin{array}{lr}9 & \\ 24 & \text { Culicoides } \\ 7 & \text { Phlebotomines } \\ 3 & \text { Mosquitoes } \\ 7 & \text { Culicoides } \\ 5 & \\ 3 & \text { Mosquitoes } \\ 20 & \text { Ticks } \\ 6 & \text { Culicoides } \\ 2 & \\ 2 & \text { Culicoides }\end{array}$

Corriparta

Epizootic hemorrhagic disease

GENUS

COLTIVIRUS

TYPE SPECIES COLORADO TICK FEVER VIRUS (FLORIO STRAIN)

Equine encephalosis

Eubenangee

Kemerovo

Palyam

Wallal

Warrego

COLTIVIRI

\section{Properties of The Virus Particle}

Morphology

Sperical particles $80 \mathrm{~nm}$ in diameter with two outer capsid shells and a core which possesses no projections. Surface capsomeric structure of core particles differs from orbiviruses.

Physicochemical properties

Nucleic Acid

Protein

Carbohydrate

\section{Antigenic properties}

Infectivity is lost at $\mathrm{pH}$ 3.0. Lipids solvents reduce infectivity.

12 segments with $\mathrm{MW}=0.24-2.5 \times 10^{6} ;$ total $\mathrm{MW} \approx 18 \mathrm{x}$ $10^{6}$.

\section{Unknown.}

Unknown.

Only two known serotypes exist, and these are represented by North American isolates and the European isolate, Eyach. Antigenic variants of the North American serotype have been reported.

\section{REPLICATION}

Replication takes place in cytoplasmic viroplasms. Morphogenesis is accompanied by formation of regularly structured filaments and tubules. 
Host range

Transmission

\section{Biological ASPECTS}

Primarily Ixodidae ticks, but 12 segmented dsRNA viruses have been isolated from mosquitoes. Vertebrate species in which the virus replicates and has been isolated include man, deer, and small animals. Man represents an accidental host. Isolations have been made repeatedly in North America from Dermacentor andersoni. Indonesian isolates have been made from mosquitoes, and Chinese isolates, from ticks, cattle, pigs and man.

Vectored by ticks, and possibly mosquitoes (Indonesian isolates).

\section{OTHER MEMBERS}

Eyach

Ar 577 (Eyach antigenic variant)

Ar 578 (Eyach antigenic variant)

\section{Probable members}

$\begin{array}{ll}\text { Indonesian isolates } & \text { JKT-6423 } \\ & \text { JKT-6969 } \\ & \text { JKT-7041 } \\ & \text { JKT-7075 } \\ \text { Chinese isolates } & \text { M14 } \\ & \text { HN59 } \\ & \text { HN131 } \\ & \text { HN199 } \\ & \text { HN295 }\end{array}$

\begin{tabular}{lcc}
\hline \hline GENUS & - & ROTAVIRUS \\
\hline TYPE SPECIES & HUMAN ROTAVIRUS & - \\
\hline
\end{tabular}

Properties of The Virus Particle

Morphology Particles 65-75 nm in diameter with two outer capsid shells and a core without spikes. The capsomers are composed of shared subunits; symmetry is $\mathrm{T}=13$ (laevo).

Physicochemical $S_{20 w} \approx 525$; buoyant densities of particles and cores are properties

$1.36-1.38$ and $1.44 \mathrm{~g} / \mathrm{cm}^{3}$, respectively. Infectivity is stable at pH 3.0 and relatively heat-stable. Resistant to ether.

Nucleic acid
11 segments with $\mathrm{MW}=0.4-2.1 \times 10^{6}$; total $\mathrm{MW} \approx 12 \mathrm{x}$ $10^{6} ; 12-15 \%$ by weight of virus for group A. Short 
conserved sequences at all 5' ends, and (distinct) at all 3' ends.

Protein

\section{Antigenic} properties

Host range

\section{Transmission}

6 structural proteins (MW $\left.=34-125 \times 10^{3}\right)$ for group A. Removal of outer capsid (at low $\mathrm{Ca}^{++}$concentration) required for transcriptase activity. Capping enzymes present.

6 serogroups described; the major group antigen is the major inner capsid protein VP6. Within group A, two VP6 subgroups and 11 distinct serotypes based on outer capsid glycoprotein VP7 (designated G1-11) are recognized. There are about 9 VP4 (P) "serotypes" based on sequences as there is partial antigenic overlap. Characterization of groups B-F is limited as most strains grow only in their original hosts.

\section{REPLICATION}

Unlike orthoreoviruses, rotaviruses enter the cytoplasm directly through the plasma membrane, not via endocytotic vesicles. Penetration depends on VP4 after specific cleavage by trypsin. Transcription like that of Orthoreovirus. 5 nonstructural proteins, one mediates budding of single capsid particles into endoplasmic reticulum. Final assembly occurs within cisternae of ER, after separate secretion of the glycoprotein VP7. In vivo, replication restricted to intestinal ephithelial cells.

\section{Biological ASPECTS}

Mammals and birds. Diarrhoeal disease is caused by homologous virus in humans, mice, calves, piglets, turkeys etc. Group A serotypes G3, G4, G8 and G9 found in both humans and other mammals, host specificity mainly dependent on VP4.

Horizontal. No vectors. Environmental contamination.

\section{OTHER MEMbERS}

Group A rotaviruses have been identified in most mammalian and avian species studied. Group B rotaviruses occur in humans, pigs, cattle, sheep and rats. Group $C$ viruses are found in pigs and rarely in humans; groups $\mathrm{D}$ and $\mathrm{F}$ in poultry, and group $\mathrm{E}$ in pigs. 
GENUS $-$

AQUAREOVIRUS

TYPE SPECIES GOLDEN SHINER VIRUS

(GSV)

\section{Properties of The Virus Particle}

Morphology External appearance similar to Orthoreovirus, $\approx 75 \mathrm{~nm}$ in diameter; core $\approx 50 \mathrm{~nm}$.

Physicochemical Buoyant density $1.36 \mathrm{~g} / \mathrm{cm}^{3}$. Infectivity resistant to ether properties and proteolytic enzymes.

Nucleic acid 11 segments with $\mathrm{MW}=0.3-2.5 \times 10^{6}$, total $\mathrm{MW}=\approx 15$ x $10^{6}$.

Protein

5 major structural proteins with $\mathrm{MW}=34-135 \times 10^{3}$. At least 2 other minor virion proteins present.

\section{REPLICATION}

In cytoplasm, probably like orthoreoviruses.

\section{Biological ASPECTS}

Host range

Poikilotherm vertebrates and invertebrates (fish and shellfish). Efficient replication in fish cell lines.

Transmission Horizontal; no vectors identified.

\section{OTHER MEMBERS}

$13 \mathrm{p} 2$ reovirus $(13 \mathrm{p} 2)$

Chum salmon virus (CSV)

Channel catfish reovirus (CRV)

Probable members

Tench reovirus

Chub reovirus

Coho salmon reovirus

Hard clam reovirus

\section{Possible members}

Grass carp reovirus

Turbot reovirus 


\begin{tabular}{llc}
\hline \hline GENUS & CYTOPLASMIC POLYHEDROSIS & CYPOVIRUS \\
& VIRUS GROUP & - \\
\hline TYPE SPECIES & CYTOPLASMIC POLYHEDROSIS & - \\
& VIRUS (CPV) FROM & \\
& BOMBYX MORI & \\
\hline
\end{tabular}

\section{Properties of The Virus Particle}

Morphology Spherical particles, $50-65 \mathrm{~nm}$ diameter with 12 apparently hollow spikes located at icosahedral vertices. Dense core surrounded by an outer shell, but no clearly defined outer capsid structure like that of orthoreoviruses.

Physicochemical $\mathrm{MW} \approx 50 \times 10^{6} ; \mathrm{S}_{20 \mathrm{w}}=370-440$. Stable at $\mathrm{pH} 3.0$; properties infectivity lost after $10 \mathrm{~min}$ at $80-85^{\circ} \mathrm{C}$; resistant to ether. Capsid resistant to proteolytic enzymes such as chymotrypsin.

Nucleic acid 10 segments of dsRNA with MW $=0.3-2.7 \times 10^{6} ; 25-$ $30 \%$ by weight of virus; $\mathrm{G}+\mathrm{C}=36-42 \%$. Segments have no homology with members of other genera. Positive strands of virion RNA are methylated and capped at the 5' terminus.

Protein $\quad 3-5$ proteins, $\mathrm{MW}=30-151 \times 10^{3} ; 70-75 \%$ by weight of virus. Transcriptase in particle does not require treatment with proteolytic enzymes for activation. Also present: nucleotide phosphohydrolase; capping enzymes; exonuclease; hemagglutinin for chick, sheep, and mouse erythrocytes.

\section{REPLICATION}

Probably like orthoreoviruses. Many virus particles are occluded with 'polyhedra' composed of one major protein, $\mathrm{MW}=25-30 \times 10^{3}$, which is probably a glycoprotein.

\section{Biological ASPECTS}

Pronounced cellular tropism for midgut epithelial cells.

Host range Insects: Lepidoptera, Diptera, Hymenoptera. Crustacea: Simocephalus.

Transmission Horizontal. 


\section{OTHER MEMBERS}

Eleven 'types' defined by the distinctive electrophoretic profiles of their RNA genome segments (in addition to type 1 , the type species):

Type 2 from Inachis io

Type 3 from Spodoptera exempta

Type 4 from Actias selene

Type 5 from Trichoplusia ni

Type 6 from Biston betularia

Type 7 from Triphena pronuba

Type 8 from Abraxas grossulariata

Type 9 from Agrotis segetum

Type 10 from Aporophylla lutulenta

Type 11 from Spodoptera exigua

Type 12 from Spodoptera exempta

\section{Probable members}

Viruses from $\approx 150$ different insect species.

\begin{tabular}{lll}
\hline \hline GENUS & PLANT REOVIRUS & PHYTOREOVIRUS \\
& SUB-GROUP 1 & \\
\hline TYPE SPECIES & $\begin{array}{l}\text { WOUND TUMOR VIRUS } \\
\text { (WTV) (34) }\end{array}$ & - \\
\hline
\end{tabular}

\section{Properties of The Virus Particle}

Morphology Particles 65-70 $\mathrm{nm}$ in diameter. WTV possesses an outer amorphous layer (2 proteins), an outer layer of distinct capsomers, and a smooth core ( 3 proteins, $\mathrm{MWs} \approx 58$, 118 , and $\left.160 \times 10^{3}\right)$. The core is $45-60 \mathrm{~nm}$ in diameter and lacks spikes.

Physicochemical $\quad \mathrm{MW} \approx 75 \times 10^{6} ; \mathrm{S}_{20 \mathrm{w}} \approx 510$. Optimal stability at $\mathrm{pH} 6.6$. properties Resistant to freon and $\mathrm{CCl}_{4}$.

Nucleic acid

12 segments with $\mathrm{MW}=0.3-3.0 \times 10^{6}$, with total $\mathrm{MW} \approx$ $16 \times 10^{6} ; 22 \%$ by weight of virus; $\mathrm{G}+\mathrm{C}=38-44 \%$. Each of the 12 WTV genomic segments contains the conserved oligonucleotides (+) 5'GGUAUU...UGAU3'. The genomic segments of all three phytoreoviruses contain conserved terminal oligonucleotides with the consensus sequence (+) 5'GGU/CA...U/CGAU3'.

Protein

Seven proteins with MWs ranging from 35-160 x 103; $78 \%$ by weight of virus. Removal of outer shell not required for activation of transcriptase. 


\section{Antigenic} Properties

Host range

Transmission
All three members of the genus are antigenically unrelated to each other.

\section{REPLICATION}

In cytoplasm, probably like that of orthoreoviruses. Continuous propagation in plants without access to vectors can lead to the selection of mutants that lack some genome segments and which may no longer replicate in the insect.

\section{Biological ASPECtS}

In nature, WTV was originally found once, in the leafhopper Agalliopsis novella. A second isolate (New Jersey strain) was recently detected in a single Vinca major plant set out as a bait plant in a blueberry field. Experimental host range of WTV is wide among dicotyledonous plants. Rice dwarf and rice gall dwarf viruses have narrow host ranges among the Gramineae. WTV grows in cell lines derived from embryonic tissues of vectors.

Phytoreoviruses are transmitted only by cicadellid leafhoppers (Agallia, Agalliopsis, Nephotettix, etc.). Transmission is propagative; acquisition after $1 \mathrm{~min}$ or more; latent period $\approx 2$ weeks, then lifelong transmission by insects to plants. Transovarial in insect vectors.

\section{OTHER MEMBERS}

Rice dwarf virus (102)

Rice gall dwarf virus (296)

\begin{tabular}{llc}
\hline \hline GENUS & PLANT REOVIRUS SUBGROUP 2 & FIJIVIRUS \\
\hline TYPE SPECIES & FIJI DISEASE VIRUS (FDV) (119) & - \\
\hline
\end{tabular}

\section{Properties of the Virus Particle}

Morphology

Particles $65-70 \mathrm{~nm}$ in diameter (in uranyl acetate). 12 external knobs $\approx 11 \mathrm{~nm}$ in diameter and $9-11 \mathrm{~nm}$ long (A spikes); particles break down spontaneously in vitro to give spiked cores $54 \mathrm{~nm}$ in diameter, which have 12 icosahedrally located spikes (B spikes, $\approx 8 \mathrm{~nm}$ high, 11 $13.5 \mathrm{~nm}$ wide). Treatment of maize rough dwarf virus (MRDV) with various reagents produces smooth (spikeless) cores, $50-57 \mathrm{~nm}$ in diameter containing 2 proteins, $\mathrm{MW} \approx 126$ and $139 \times 10^{3}$. 
Physicochemical Not established. properties

Nucleic acid

10 segments, $\mathrm{MW}=1.0-2.9 \times 10^{6}$ with total $\mathrm{MW}=18-20$ $\mathrm{x} 10^{6} ; \mathrm{G}+\mathrm{C} .=45 \%$. Three RNA segments of maize rough dwarf virus and one of rice black streaked virus have been shown to have the same conserved oligonucleotides (+) 5'AAGUUUUUU...UGUC3' which differ from the phytoreoviruses.

Protein

Antigenic properties

Host range

Transmission
For MRDV, 6 proteins MW $=64-139 \times 10^{3}$.

Serological studies complicated by presence of antibodies to dsRNA in many antisera. Viruses fall into three serologically unrelated clusters (FDV, MRDV and OSDV) based on protein antigens associated with B-spiked subviral particles.

\section{REPLICATION}

In cytoplasmic viroplasms, probably like that of orthoreoviruses. Morphogenesis is accompanied by formation of regularly structured filaments and tubules in at least some hosts.

\section{Biological ASPECtS}

Flowering plants; Gramineae. Insects: plant hoppers (Delphacidae, Auchenorrhyncha, Hemiptera).

In nature only by Delphacid plant hoppers, e.g., Laodelphax, Javesella, Delphacodes, Sogatella, Perkinsiella, Unkanodes, etc. Transmission is propagative; acquisition after some hours feeding; latent period $\approx 2$ weeks; then lifelong transmission by the insect to plants. FDV can be transmitted inefficiently through the egg; probably no transovarial transmission in other members.

\section{OTHER MEMBERS}

Maize rough dwarf (Pangola stunt (175), Rice black streaked dwarf (135), cereal tillering disease and mal de Rio Cuarto disease are considered geographical races of maize rough dwarf virus).

Oat sterile dwarf (= Arrhenatherum blue dwarf and lolium enation viruses). 


\begin{tabular}{lll}
\hline \hline $\begin{array}{l}\text { POSSIBLE } \\
\text { GENUS }\end{array}$ & PLANT REOVIRUS SUBGROUP 3 & - \\
\hline TYPE SPECIES & RICE RAGGED STUNT (RRSV) (248) \\
\hline
\end{tabular}

\section{Properties of The Virus Particle}

Morphology Particle lacks a complete outer capsid; core $\approx 50 \mathrm{~nm}$ in diameter; there are 12 spikes $15-20 \mathrm{~nm}$ wide and $8 \mathrm{~nm}$ long that represent a partially formed outer capsid.

Physicochemical Not determined. properties

Nucleic acid

10 segments, $\mathrm{MW}=0.5-3.0 \times 10^{6}$, with total $\mathrm{MW} \approx 18 \mathrm{x}$ $10^{6}$. RNA polymerase present in virions.

Protein Not determined.

REPLICATION

In cytoplasmic viroplasms, similar to other Reoviridae.

\section{Biological ASPEcts}

Host range Flowering plants; Gramineae. Insects: plant hoppers (Delphacidae, Auchenorrhyncha, Hemiptera).

Transmission Propagative, in the plant hopper Nilaparvata; acquisition after some $3 \mathrm{~h}$ feeding, latent period $\approx 10$ days; then intermittent, lifelong transmission. No transovarial transmission.

\section{OTHER MEMBERS}

\section{Possible member}

Echinochloa ragged stunt virus.

\section{NOTE}

RRSV is suggested as a possible new genus because it has a distinct morphology unlike any other reo-like virus (though it somewhat resembles Cypovirus without the matrix protein). The size distribution of the $10 \mathrm{dsRNA}$ segments is unlike that of other Reoviridae. No serological relationships with any other plant reo-like virus. On the other hand, the symptoms, cytopathology, vector type and number of RNA segments, are similar to those of Fijivirus. 
Derivation of Names

reo: sigla from respiratory enteric orphan

orbi: from Latin orbis, 'ring'

colti: from Colorado tick fever

rota: from Latin rota, 'wheel'

aqua: from Latin aqua, 'water'

cypo: cytoplasmic polyhedrosis

phyto: from Greek phyton, 'plant'

fiji: from name of country from which virus was first described

\section{REFERENCES}

Barber, T.L.; Jochim, M.M.: Bluetongue and related orbiviruses (Liss, New York 1985).

Belloncik, S.: Cytoplasmic polyhedrosis viruses - Reoviridae. Adv. Virus Res. 37: 173-209 (1989).

Boccardo, G.; Milne, R.G.: Plant reovirus group. CMI/AAB Descriptions of Plant Viruses No. 294 (1984).

Bridger, J.C.: Novel rotaviruses in animals and man. In Novel Diarrhoea Viruses, Ciba Found. Sympos. 128: 5-23 (Wiley, Chichester 1987).

Estes, M.K.; Cohen, J.: Rotavirus gene structure and function. Microbiol. Revs. 53: 410-449 (1989).

Francki, R.I.B.; Boccardo, G.: The plant reoviridae. In Joklik, W.K. (ed.), The Reoviridae, pp. 505-563 (Plenum Press, New York, 1983).

Francki, R.I.B.; Milne, R.G.; Hatta, T.: Plant reoviridae, In Atlas of Plant Viruses, Vol. I, pp. 47-72 (CRC Press, Boca Raton, Fl., 1985).

Gorman, B.M.; Taylor, J.; Walker, P.J.: Orbiviruses. In Joklik, W.K. (ed.) The Reoviridae, pp. 287-358 (Plenum Press, New York, 1983).

Hull, R.; Brown, F.; Payne, C.: Virology - Directory and dictionary of animal, bacterial and plant viruses, pp. 266-271 (Macmillan, London 1989).

Joklik, W.K.: The Reoviridae, (Plenum Press, New York, 1983).

Joklik, W.K.: Recent progress in reovirus research. Ann. Rev. Genet. 19:537-575 (1985).

Kapikian, A.Z.; Chanock, R.M.: Rotaviruses. In Fields, B.N.; Knight, J.C. (eds.), Virology, 2nd edn., pp. 1353-1404 (Raven Press, New York, 1990).

Knudson, D.L.: Genome of Colorado tick fever virus. Virology 112: 361-364 (1981).

Knudson, D.L.; Monath, T.P.: Orbiviruses. In Fields, B.N.; Knight, J.C. (eds.), Virology, 2nd edn., pp. 1405-1433 (Raven Press, New York, 1990).

Mertens, P.P.C.; Crook, N.E.; Rubinstein, R.; Pedley, S.; Payne, C.C.: Cytoplasmic polyhedrosis virus classification by electropherotype: validation by serological analyses and agarose gel electrophoresis. J. gen. Virol. 70: 173-185 (1989).

Mertens, P.P.C.; Pedley, S.; Cowley, J.; Burroughs, J.N.; Corteyn, A.H.; Jeggo, M.H.; Jennings, D.M.; Gorman, B.M.: Analysis of the roles of bluetongue virus outer capsid proteins VP2 and VP5 in determination of virus serotype. Virology 170: 561-565 (1989).

Nuss, D.L.; Dall, D.J.: Structural and functional properties of plant reovirus genomes. Adv. Virus Res. 38: 249-306 (1990).

Payne, C.C.; Mertens, P.P.C.: Cytoplasmic polyhedrosis viruses. In Joklik, W.K. (ed.), The Reoviridae, pp. 425-504 (Plenum Press, New York, 1983).

Pedley, S.; Bridger, J.C.; Brown, J.F.; McCrae, M.A.: Molecular characterization of rotaviruses with distinct group antigens. J. gen. Virol. 64:2093-2101 (1983).

Ray, P.; Gorman, B.M.: Bluetongue viruses. Cur. Topics. Microbiol. Immunol. 162 (Springer, Berlin, Heidelberg, New York, Tokyo, 1990). 
Schiff, L.A.; Fields, B.N.: Reoviruses and their replication. In Fields, B.N.; Knight, J.C. (eds.), Virology, 2nd edn., pp. 1275-1306 (Raven Press, New York, 1990).

Tyler, K.L.; Fields, B.N.: Reoviridae: A brief introduction. In Fields, B.N.; Knight, J.C. (eds.), Virology, 2nd edn., pp. 1271-1274 (Raven Press, New York, 1990).

Tyler, K.L.; Fields, B.N.: Reoviruses. In Fields, B.N.; Knight, J.C. (eds.), Virology, 2nd edn., pp. 1307-1328 (Raven Press, New York, 1990).

Winton, J.R.; Lannan, C.N.; Fryer, J.L.; Hedrick, R.P.; Meyers, T.R.; Plumb, J.A.; Yamamoto, T.: Morphological and biochemical properties of four members of a novel group of reoviruses isolated from aquatic animals. J. gen. Virol. 68: 353-364 (1987). 


\begin{tabular}{|ll|}
\hline FAMILY & $\begin{array}{l}\text { BISEGMENTED DSRNA } \\
\text { VIRUS GROUP }\end{array}$ \\
\hline
\end{tabular}

Reported by P. Dobos

\begin{tabular}{llc}
\hline \hline GENUS & \multicolumn{1}{c}{ BIRNAVIRUS } \\
\hline TYPE SPECIES & INFECTIOUS PANCREATIC & - \\
& NECROSIS VIRUS (IPNV) & - \\
\hline
\end{tabular}

\section{Properties of the Virus Particle}

Morphology Icosahedral particles $\approx 60 \mathrm{~nm}$ in diameter with 92 morphological subunits with no envelope or surface projections. Cores are $45 \mathrm{~nm}$ in diameter as seen in thin sections of infected cells. Cores cannot be generated by treating purified virus with EDTA, trypsin or chymotrypsin.

Physicochemical $\mathrm{MW} \approx 55 \times 10^{6} ; \mathrm{S}_{20 \mathrm{w}} \approx 435$; buoyant density in $\mathrm{CsCl}=$ properties $1.33 \mathrm{~g} / \mathrm{cm}^{3}$. Stable at $\mathrm{pH} 3-9$, resistant to $1 \% \mathrm{SDS}$ at $20^{\circ} \mathrm{C}$ at $\mathrm{pH} 7.5$ for $30 \mathrm{~min}$.

Nucleic acid

Two segments of linear dsRNA, $9.7 \%$ by weight of virus particle, not infectious. Both segments contain a $94 \mathrm{kDa}$ genome linked protein. Genome segment A (3092 bp) contains a large ORF that encodes a $104 \mathrm{kDa}$ polyprotein in the order of 5'-pre VP2-NS-VP3-3'. A small $17 \mathrm{kDa}$ ORF which overlaps the large ORF at its 5'-end has been identified in IPNV and IBDV sequences; gene product of this small ORF has not been identified in either systems. Segment B (2784 bp) contains a single large ORF that encodes a $94 \mathrm{kDa}$ polypeptide, the putative RNA polymerase.

Protein

Four structural polypeptides: VP1 (94 kDa ) a minor protein present both as free and as genome linked protein. VP2 (54 kDa ), VP3 (31 kDa) and VP4 $(29 \mathrm{kDa})$. The latter represents a truncated VP3 in IPNV whereas it is a unique polypeptide in IBDV and DXV. All viruses contain a dsRNA dependent RNA polymerase activity.

Lipid No lipids in virion.

Carbohydrate VP2 is glycosylated.

Antigenic The major capsid protein VP2 contains the virus properties neutralizing epitopes. Monoclonal Ab's to VP3 do not 
Effect on cells Tissue tropism of pancreas, gonad, kidney for IPNV, bursa Fabricius for IBDV.

\section{REPLICATION}

A sinlge cycle of replication takes $16-20 \mathrm{~h}$. Replication is cytoplasmic. No inhibition of host cell macromolecular synthesis. Transcription of viral RNA involves synthesis of two genome length mRNA species (one from each genome segment) that lack 3'-poly A tails. It is not known if genome replication follows a conservative or semi conservative mechanism. Peak rates of viral RNA and protein synthesis are reached approximately 6-8 hours post infection. Four virus-specific polypeptides are found in infected cells: VP1 the product of genome segment $B$, and preVP2 $(62 \mathrm{kDa}), \mathrm{NS}(27 \mathrm{kDa})$ and VP3 the product of genome segment $\mathrm{A}$. These three polypeptides are generated by cotranslational cleavage by the virus coded endoprotease (NS in IPNV; NP4 in IBDV and DXV) which cleaves the polyprotein at two places. The exact cleavage sites have not been mapped but the carboxy end of the NS polypeptide comprises the active site of the viral protease. PreVP2 is later trimmed to VP2 during virus maturation. Cells lyse, but about half the progeny remains cell associated. Genome segment reassortment between IPNV serotypes has been demonstrated in laboratory experiments.

\section{Biological Aspects}

Host range

Different viruses infecting fish, mostly salmonids (IPNV); molluscs (OV and TV); chickens, ducks and turkeys (IBDV); and Drosophila (DXV).

Transmission Both horizontal and vertical for all viruses. No vectors known.

\section{OTHER MEMBERS}

Oyster virus (OV)

Tellina virus (TV)

Infectious bursal disease virus (IBDV)

Drosophila X Virus (DXV) 
Derivation of bi: signifies double strandedness, as well as the

Name

bisegmented nature of the virus genome.

rna: indicates the nature of the viral nucleic acid.

\section{REFERENCES}

Becht, H.: Infectious Bursal Disease Virus. Cur. Topics Microbiol. Immunol., 90:107-121 (1980).

Dobos, P.; Hill, B.J.; Hallett, R.; Kells, D.T.C.; Becht, H.; Teninges, D.: Biophysical and biochemical characterization of five animal viruses with bisegmented double-stranded RNA genomes. J. Virol. 32:593-605 (1979).

Dobos, P.; Roberts, T.E.: The molecular biology of infectious pancreatic necrosis virus: a review. Can. J. Microbiol. 29:377-384 (1983).

Duncan, R.; Nagy, E.; Krell, P.J.; Dobos, P.: Synthesis of the infectious pancreatic necrosis virus polyprotein, detection of a virus-coded protease, and fine structure mapping of genome segment A coding regions. J. Virol. 61: 3655-3664 (1987).

Pilcher, K.S.; Fryer, J.L.: Viral diseases of fish: a review through 1978. CRC Critical Reviews in Microbiology, Vol. 1, p.287. (CRC Press, West Palm Beach, 1980). 
Revised by K.W. Buck \& S.A. Ghabrial

\begin{tabular}{llc}
\hline \hline GENUS & MONOPARTITIE DSRNA & TOTIVIRUS \\
& MYCOVIRUS GROUP & \\
\hline TYPE SPECIES & SACCHAROMYCES CEREVISIAE & - \\
& VIRUS L-A (SCV-L-A) & \\
& (SYNONYM SCV-L1) & \\
\hline
\end{tabular}

\section{Properties of the Virus Particle}

Morphology Isometric, $40-43 \mathrm{~nm}$ in diameter .

Physicochemical $\mathrm{S}_{20 \mathrm{w}}=160-190 \mathrm{~S}$. Buoyant density in $\mathrm{CsCl}=1.40-1.43$ properties

$\mathrm{g} / \mathrm{cm}^{3}$. Additional components with different sedimentation coefficients and buoyant densities are present in virus isolates with satellite or defective RNAs. Particles lacking nucleic acid have $S_{20 \mathrm{w}}=98-113 \mathrm{~S}$.

Nucleic acid

Single molecule of dsRNA, MW $=3.3-4.2 \times 10^{6}$ (4.7-6.7 $\mathrm{kbp}$ ). Some virus isolates contain additional satellite dsRNAs which encode "killer" proteins; these satellites are encapsidated separately in capsids encoded by the helper virus genome. Some virus isolates may contain additionally or alternatively to the satellites, subgenomic or defective dsRNAs which arise from the satellite dsRNAs; these additional dsRNAs are also encapsidated separately in capsids encoded by the helper virus genome.

The complete nucleotide sequence of ScV-L-A (ScV-L1) dsRNA is deposited as EMBL accession number J04692 (X13426). The plus strand (4579 bases) has two large ORFs that overlap by 130 bases. The first ORF encodes the viral major capsid polypeptide with a predicted size of $76 \times 10^{3}$. The two ORF together encode via translational frame shift, the putative RNA-dependent RNA polymerase as a fusion protein (analogous to gag-pol fusion proteins of the retroviruses) with a predicted size of $171 \times 10^{3}$.

Protein Single major capsid polypeptide species, $\mathrm{MW}=73-88 \mathrm{x}$ $10^{3}$. RNA polymerase (transcriptase) present.

Lipid None detected.

Carbohydrate None detected. 
Antigenic properties

Transmission
Efficient immunogens.

\section{REPLICATION}

The virion-associated RNA polymerase catalyses in vitro end-to-end transcription of dsRNA by a conservative mechanism to produce mRNA for capsid polypeptide. The $(+)$ ssRNA transcript of ScV-L-A is the species encapsidated to form new virus particles having a replicase activity. These particles synthesize (-) strand on the (+) template to produce dsRNA, thus completing the replication cycle. Virions accumulate in the cytoplasm.

\section{Biological ASPECTS}

Intracellular during cell division, sporogenesis and cell fusion. In some ascomycetes, e.g. Gaeumannomyces graminis, virus is usually eliminated during ascospore formation.

\section{OTHER MEMBERS}

Helminthosporium victoriae $190 \mathrm{~S}$ virus

Ustilago maydis viruses (P1, $\mathrm{P} 4$ and $\mathrm{P} 6)$

\section{Probable members}

Gaeumannomyces graminis virus 87-1-H (Ggv-87-1-H)

Mycogone perniciosa virus (MpV)

Yarrowia lipolytica virus (YIV)

\section{Possible members}

Aspergillus foetidus virus S (AfV-S)

Aspergillus niger virus S (AnV-S)

Saccharomyces cerevisiae virus $\mathrm{La}(\mathrm{ScV}-\mathrm{La}$; synonym $\mathrm{ScV}-\mathrm{LB} / \mathrm{C})$

Thielaviopsis basicola viruses

Derivation of totus: from Latin 'whole' or 'undivided' 


\section{REFERENCES}

Adler, J.J.; Wood, H.A.; Bozarth, R.F.: Virus-like particles from killer, neutral and sensitive strains of Saccharomyces cerevisiae. J. Virol. 17:472-476 (1976).

Barton, R.J.: Mycogone perniciosa virus. Report of the Glasshouse Crops Research Institute for 1977 , p. 133 (1978).

Bozarth, R.F.; Goenaga, A.: Complex of virus-like particles containing double-stranded RNA from Thielaviopsis basicola. J. Virol. 24:846-849 (1977).

Bozarth, R.F.; Koltin, Y.; Weissman, M.B.; Parker, R.L.; Dalton, R.E.; Steinlauf, R.: The molecular weight and packaging of dsRNAs in the mycovirus from Ustilago maydis killer strains. Virology 113:492-502 (1981).

Brennan, V.E.; Field, L.J.; Cizdziel, P.; Bruenn, J.A.: Sequences at the 3' ends of yeast viral dsRNAs: proposed transcriptase and replicase initiation sites. Nuc. Acids Res. 9:40074021 (1981).

Buck, K.W.; Girvan, R.F.; Ratti, G.: Two serologically distinct double-stranded RNA viruses isolated from Aspergillus niger. Biochem. Soc. Trans. 1:1138-1140 (1973).

Buck, K.W.; Lhoas, P.; Border, D.J.; Street, B.K.: Virus particles in yeast. Biochem. Soc. Trans. 1:1141-1142 (1973).

Buck, K.W.; Ratti, G.: Biophysical and biochemical properties of two viruses isolated from Aspergillus foetidus. J. gen. Virol. 27:211-224 (1975).

Bussey, H.: Proteases and the processing of precursors to secreted proteins in yeast. Yeast 4:17-26 (1988).

Diamond, M.E.; Dowhanick, J.J.; Nemeroff, M.E.; Pietras, D.F.; Tu, C.C.; Bruenn, J.A.: Overlapping genes in a yeast double-stranded RNA virus. J. Virol. 63: 3983-3990 (1989).

Fujimura, T.; Wickner, R.B.: L-A double-stranded RNA virus-like particle replication cycle in Saccharomyces cerevisiae: Particle maturation in vitro and effects of mak 10 and pet 18 mutations. Mol. Cell. Biol. 7: 420-426 (1987).

Fujimura, T.; Wickner, R.B.: Gene overlap results in a viral protein having an RNA binding domain and a major coat protein domain. Cell 55: 663-671 (1988).

Ghabrial, S.A.; Bibb, J.A.; Price, K.H.; Havens, W.M.; Lesnaw, J.A.: The capsid polypeptides of the $190 \mathrm{~S}$ virus of Helminthosporium victoriae. J. gen. Virol. 68:17911800 (1987).

Ghabrial, S.A.; Havens, W.M.: Conservative transcription of Helminthosporium victoriae 190S virus double-stranded RNA in vitro. J. gen. Virol. 70: 1025-1035 (1989).

Groves, D.P.; Clare, J.J.; Oliver, S.G.: Isolation and characterisation of a double-stranded RNA virus-like particle from the yeast Yarrowia lipolytica. Curr. Genet. 7: 185-190 (1983).

Hopper, J.E.; Bostian, K.A.; Rowe, L.B.; Tipper, D.J.: Translation of the L-species dsRNA genome of the killer-associated virus-like particles of Saccharomyces cerevisiae. J. Biol. Chem. 252:9010-9017 (1977).

Icho, T.; Wickner, R.B.: The double-stranded RNA genome of yeast virus L-A encodes its own putative RNA polymerase by fusing two open reading frames. J. Biol. Chem. 264 : 6716-6723 (1989).

Jamil, N.; Buck, K.W.: Apparently identical viruses from Gaeumannomyces graminis var. tritici and Phialophora sp. (lobed hyphopodia). Trans. Brit. Mycol. Soc. 83:519-522 (1984).

Jamil, N.; Buck, K.W.: Capsid polypeptides in a group III virus from Gaeumannomyces graminis var. tritici are related. J. gen. Virol. 67:1717-1720 (1986).

Koltin, Y.: Virus-like particles in Ustilago maydis: mutants with partial genomes. Genetics 86:527-534 (1977).

Nemeroff, M.E.; Bruenn, J.A.: Conservative replication and transcription of Saccharomyces cerevisiae viral double-stranded RNA in vitro. J. Virol. 57:754-758 (1986).

Shelbourn, S.L.; Day, P.R.; Buck, K.W.: Relationships and functions of virus double-stranded RNA in a P4 killer strain of Ustilago maydis. J. gen. Virol. 69: 975-982 (1988).

Wickner, R.B.; Yeast virology. FASEB J. 3:2257-2265 (1989). 


\begin{tabular}{llc}
\hline \hline GENUS & $\begin{array}{l}\text { GIARDIA VIRUS GROUP } \\
\text { (POSSIBLE AFFINITIES TO THE TOTIVIRIDAE FAMILY) }\end{array}$ \\
\hline TYPE SPECIES & $\begin{array}{l}\text { GIARDIA LAMBLIA VIRUS } \\
\text { (GLV) }\end{array}$ \\
\hline
\end{tabular}

Compiled by S.A. Ghabrial \& C.C. Wang

\section{Properties of the Virus Particle}

Morphology Isometric, $33 \mathrm{~nm}$ in diameter.

Physicochemical Buoyant density in $\mathrm{CsCl} \approx 1.368 \mathrm{~g} / \mathrm{cm}^{3}$. properties

Nucleic acid Single molecule of dsRNA $\approx 7.0 \mathrm{kbp}$ in length.

Protein Single major capsid species, MW $\approx 100 \times 10^{3}$.

Lipid None reported.

Carbohydrate None reported.

\section{REPLICATION}

The virus is present in the nuclei of infected G. lamblia. It replicates without inhibiting the growth of G. lamblia trophozoites. It is also extruded into the culture medium and the extruded virus can infect many virus-free isolates of the protozoan host. There are isolates of the protozoan parasite, however, that are resistant to infection by GLV. A single-stranded copy of the viral dsRNA genome is present in infected cells. The concentration of the ssRNA observed during the time course of GLV infection is consistent with a role as a viral replicative intermediate or mRNA. The ssRNA does not appear to be polyadenylated.

\section{Biological ASPECTS}

The virus infects many isolates of $G$. lamblia, a flagellated protozoan human parasite. The virus does not seem to be associated with the virulence of the parasite. It is not observed in the cyst form of the parasite and it is not known whether it can be carried through the transformation between cyst and trophozoite. The virus is infectious as purified particles and can infect uninfected $G$. lamblia.

Possible member

Trichomonas vaginalis virus (TVV) 


\section{REFERENCES}

Furfine, E.S.; White, T.C.; Wang, A.L.; Wang, C.C.: A single-stranded RNA copy of the Giardia lamblia virus double-stranded RNA genome is present in the infected Giardia lamblia. Nuc. Acids Res. 17: 7453-7467 (1989).

Miller, R.L.; Wang, A.L.; Wang, C.C.: Purification and characterization of the Giardia lamblia double-stranded RNA virus. Mol. Biochem. Parasitol. 28: 189-196 (1988).

Wang, A.L.; Wang, C.C.: Discovery of a specific double-stranded RNA virus in Giardia lamblia. Mol. Biochem. Parasitol. 21: 269-276 (1986).

Wang, A.L.; Wang, C.C.: The double-stranded RNA in Trichomonas vaginalis may originate from virus-like particles. Proc. Natl. Acad. Sci. USA 83: 7956-7960 (1986).

White, T.C.; Wang, C.C.: RNA dependent RNA polymerase activity associated with the double-stranded RNA virus of Giardia lamblia. Nuc. Acids Res. 18: 553-559 (1990). 


\begin{tabular}{|ll|}
\hline FAMILY & DSRNA MYCOVIRUSES \\
& WITH DIVIDED GENOMES
\end{tabular}

Revised by K.W. Buck \& S.A. Ghabrial

\begin{tabular}{llc}
\hline \hline GENUS & $\begin{array}{l}\text { BIPARTITE DSRNA } \\
\text { MYCOVIRUS GROUP }\end{array}$ & PARTITIVIRUS \\
\hline TYPE SPECIES & GAEUMANNOMYCES & - \\
& $\begin{array}{l}\text { GRAMINIS VIRUS 019/6-A } \\
\text { (GGV-019/6A) }\end{array}$ & \\
&
\end{tabular}

Morphology Isometric, diameter 30-35 nm.

Physicochemical $\mathrm{S}_{20 \mathrm{w}}=101-145 \mathrm{~S}$. Buoyant density in $\mathrm{CsCl}=1.35-1.36$ properties $\quad \mathrm{g} / \mathrm{cm}^{3}$. In preparations of some viruses, e.g. PsV-S, additional sedimenting and density components are found. These consist of particles with ssRNA (mRNA) and particles with both ss and dsRNA and are probably replicative intermediates. Particles lacking nucleic acid have $S_{20 w}=66-100 S$; buoyant density in $\mathrm{CsCl}=1.29$ $1.30 \mathrm{~g} / \mathrm{cm}^{3}$.

Nucleic acid

Two unrelated segments of dsRNA, MW $=0.9-1.6 \times 10^{6}$ (for individual segments), one encoding the capsid polypeptide and the other an unrelated polypeptide, probably the virion RNA polymerase. Approximately the whole of the coding capacity of each dsRNA is required for each polypeptide i.e. each dsRNA is probably monocistronic. Each dsRNA is encapsidated in a separate particle. Additional segments of dsRNA (satellite or defective) may be present in some virus isolates.

Protein

Lipid

Carbohydrate

Antigenic properties
Single major capsid polypeptide species, $\mathrm{MW}=42-73 \mathrm{x}$ $10^{3}$. RNA polymerase present.

None detected.

None detected.

Efficient immunogens. Single precipitin line in gel diffusion tests. Members and probable members which are serologically related, e.g. PsV-S, DrV and Aov, may be strains of a virus species. 


\section{REPLICATION}

The virion-associated RNA polymerase catalyses in vitro, replication, and/or end-to-end transcription of each dsRNA to produce mRNA, by a semi-conservative mechanism. Particles accumulate in the cytoplasm.

\section{Biological ASPECTS}

Transmission Intracellular during cell division, sporogenesis and cell fusion. In some ascomycetes, e.g. Gaeumannomyces graminis, virus is usually eliminated during ascospore formation.

\section{OTHER MEMBERS}

Agaricus bisporus virus 4 (AbV-4, mushroom virus 4) Aspergillus ochraceous virus (AoV) Gaeumannomyces graminis virus T1-A (GgV-T1-A)

Penicillium stoloniferum virus S (Ps V-S)

Rhizoctonia solani virus (RsV)

\section{Probable members}

Diplocarpon rosae virus (DrV)

Phialophora sp. (lobed hyphopodia) virus 2-2-A

(Phialophora radicicola virus 2-2-A, PrV-2-2-A)

\section{Possible member}

Penicillium stoloniferum virus F (Ps V-F)

\begin{tabular}{lll}
\hline \hline POSSIBLE & PENICILLIUM CHRYSOGENUM & - \\
GENUS & VIRUS GROUP & \\
\hline POSSIBLE & PENICILLIUM & \\
TYPE SPECIES & CHRYSOGENUM VIRUS (PCV) & - \\
\hline
\end{tabular}

\section{Properties of The Virus Particle}

Morphology Isometric, $35-40 \mathrm{~nm}$ in diameter

Physicochemical $S_{20 w}=145-150$. properties

Nucleic acid

Three unrelated dsRNA components with $\mathrm{MW}$ in the range $1.9 \times 10^{6}-2.4 \times 10^{6}$, each probably monocistronic, each separately encapsidated. The number of dsRNAs required for replication is not known. Some virus isolates contain additional dsRNAs, probably satellite or defective RNAs. 
Protein

Lipid

Antigenic properties

Transmission
Single major capsid polypeptide species, $\mathrm{MW} \approx 125 \mathrm{x}$ $10^{3}$. RNA polymerase present.

None detected.

Efficient immunogens. Single precipitin line in gel diffusion tests. All members are serologically related and may be strains of a single virus species.

\section{REPLICATION}

Particles accumulate in the cytoplasm.

\section{Biological ASPECTS}

Intracellular during cell division, sporogenesis and cell fusion.

OTHER MEMBERS

Penicillium brevi compactum virus $(\mathrm{PbV})$

Penicillium cyaneo-fulvum virus (Pc-fV)

\section{Possible member}

Helminthosporium victoriae $145 \mathrm{~S}$ virus

\section{Derivation of} Name

REFERENCES

Barton, R.J.; Hollings, M.: Purification and some properties of two viruses infecting the cultivated mushroom Agaricus bisporus. J. gen. Virol. 42:231-240 (1979).

Bozarth, R.F.: The physicochemical properties of mycoviruses. In Lemke, L. (ed.): Viruses and plasmids in fungi, pp. 43-91 (Dekker, New York 1979).

Bozarth, R.F.; Wood, H.A.; Goenaga, A.: Virus-like particles from a culture of Diplocarpon rosae. Phytopathology 62:493 (1972).

Bozarth, R.F.; Wood, H.A.; Mandelbrot, A.: The Penicillium stoloniferum virus complex: two similar double-stranded RNA virus-like particles in a single cell. Virology 45:516523 (1971).

Buck, K.W.: Current problems in fungal virus taxonomy. In Matthews, R.E.F. (ed.): A critical appraisal of virus taxonomy, pp. 139-176 (CRC Press, Boca Raton, Fl., 1983).

Buck, K.W.; Almond, M.R.; McFadden, J.J.P.; Romanos, M.A.; Rawlinson, C.J.: Properties of thirteen viruses and virus variants obtained from eight isolates of the wheat take-all fungus, Gaeumannomyces graminis var. tritici.. J. gen. Virol. 53:235-245 (1981). 
Buck, K.W.; Girvan, R.F.: Comparison of the biophysical and biochemical properties of Penicillium cyaneo-fulvum virus and Penicillium chrysogenum virus. J. gen. Virol. 34:145-154 (1977).

Buck, K.W.; Kempson-Jones, G.F.: Biophysical properties of Penicillium stoloniferum virus S. J. gen. Virol. 18:223-235 (1973).

Buck, K.W.; Kempson-Jones, G.F.: Capsid polypeptides of two viruses isolated from Penicillium stoloniferum. J. gen. Virol. 22:441-445 (1974).

Buck, K.W.; McGinty, R.M.; Rawlinson, C.J.: Two serologically unrelated viruses isolated from a Phialophora sp. J. gen. Virol. 55:235-239 (1981).

Edmondson, S.P.; Lang, D.; Gray, D.M.: Evidence for sequence heterogeneity among the double-stranded RNA segments of Penicillium chrysogenum mycovirus. J. gen. Virol. 65:1591-1599 (1984).

Finkler, A.; Ben-Zvi, B.; Koltin, Y.; Barash, I.: Transcription and in vitro translation of the dsRNA virus isolated from Rhizoctonia solani. Virus Genes 1: 205-219 (1988).

Finkler, A.; Koltin, Y.; Barash, I.; Sneh, B.; Pozniak, D.: Isolation of a virus from virulent strains of Rhizoctonia solani. J. gen. Virol. 66: 1221-1232 (1985).

Kim, J.W.; Bozarth, R.F.: Intergeneric occurrence of related fungal viruses: the Aspergillus ochraceous virus complex and its relationship to the Penicillium stoloniferum virus S. J. gen. Virol. 66: 1991-2002 (1985).

McFadden, J.J.P.; Buck, K.W.; Rawlinson, C.J.: Infrequent transmission of double-stranded RNA virus particles but absence of DNA proviruses in single ascospore cultures of Gaeumannomyces graminis. J. gen. Virol. 64:927-937 (1983).

Sanderlin, R.S.; Ghabrial, S.A.: Physicochemical properties of two distinct types of virus-like particles from Helminthosporium victoriae. Virology 87:142-151 (1978).

Tavantzis, S.M.; Bandy, B.P.: Properties of a mycovirus from Rhizoctonia solani and its virion-associated RNA polymerase. J. gen. Virol. 69: 1465-1477 (1988).

Wood, H.A.; Bozarth, R.F.: Properties of virus-like particles of Penicillium chrysogenum: One double-stranded RNA molecule per particle. Virology 47:604-609 (1972).

Wood, H.A.; Bozarth, R.F.; Mislivec, P.B.: Virus-like particles associated with an isolate of Penicillium brevi-compactum. Virology 44: $592-598$ (1971). 


\begin{tabular}{|lll}
\hline GROUP & CRYPTIC VIRUS GROUP & CRYPTOVIRUS \\
\hline
\end{tabular}

Revised by R. Milne

Morphology Isometric particles, $30-38 \mathrm{~nm}$ in diameter.

Physicochemical One nucleoprotein component. properties

Nucleic acid Two molecules of linear dsRNA.

Protein Single polypeptide.

Lipid None reported.

Carbohydrate None reported.

Antigenic properties

No serological relationship between members of different subgroups; some members in each subgroup are related.

\section{REPLICATION}

Virus particles of some members have been shown to contain transcriptase activity. Two proteins, $\mathrm{MW} \approx 52$ and $67 \times 10^{3}$ have been translated in vitro from the genomic dsRNAs of beet cryptic virus 1 , and $M W \approx 54$ and $68 \mathrm{x}$ $10^{3}$ from white clover cryptic virus 1 . The larger protein, derived from dsRNA 1, may be involved in dsRNA replication. The smaller protein was precipitated by antiserum to virus particles, suggesting that it is the capsid protein.

\section{Biological ASPECTS}

Host range

Narrow for individual viruses but different viruses occur in a wide range of plant families. Usually occur in very low concentration in cytoplasm and/or nucleus of host; induce no symptoms of infection, except in a few cases.

Transmission Only through seed or pollen. Viruses are possibly unable to move from cell to cell, propagating probably only via cell multiplication. 


\begin{tabular}{lll}
\hline \hline SUBGROUP I & WHITE CLOVER CRYPTIC & - \\
& VIRUS 1 GROUP & - \\
\hline TYPE MEMBER & $\begin{array}{l}\text { WHITE CLOVER CRYPTIC } \\
\text { VIRUS 1 (WCCV-1) }\end{array}$ & - \\
\hline
\end{tabular}

\section{Properties of the Virus Particle}

Morphology Isometric particles, $30 \mathrm{~nm}$ in diameter.

Physicochemical One nucleoprotein component of density $\approx 1.392 \mathrm{~g} / \mathrm{cm}^{3}$ in properties $\mathrm{CsCl}$

Nucleic acid Two molecules of linear dsRNA of MW $\approx 1.20$ and $0.97 \mathrm{x}$ $10^{6} ; \approx 25 \%$ by weight of the virus.

Protein Single polypeptide of MW $\approx 55 \times 10^{3}$.

\section{Lipid None reported.}

Carbohydrate None reported.

Antigenic Some members are serologically related. properties

\section{OTHER MEMBERS}

Alfalfa cryptic 1

Beet cryptic 1

Beet cryptic 2

Beet cryptic 3

Carnation cryptic 1 (315)

Carrot temperate 1

Carrot temperate 3

Carrot temperate 4

Hop trefoil cryptic 1

Hop trefoil cryptic 3

Radish yellow edge (298)

Ryegrass cryptic

Spinach temperate

Vicia cryptic

White clover cryptic 3

\section{Possible members}

Carnation cryptic 2

Fescue cryptic

Garland chrysanthemum temperate

Mibuna temperate

Poinsettia cryptic 
Red pepper cryptic 1

Red pepper cryptic 2

Rhubarb temperate

Santosai temperate

\begin{tabular}{lll}
\hline \hline SUBGROUP II & WHITE CLOVER CRYPTIC & - \\
& VIRUS 2 GROUP & - \\
\hline TYPE MEMBER & WHITE CLOVER CRYPTIC & - \\
& VIRUS 2 (WCCV-2) (332) \\
\hline
\end{tabular}

\section{Properties of the Virus Particle}

Morphology Isometric particles, $\approx 38 \mathrm{~nm}$ in diameter with prominent morphological subunits.

Physicochemical One nucleoprotein component of density $\approx 1.375 \mathrm{~g} / \mathrm{cm}^{3}$ in properties $\mathrm{CsCl}$

Nucleic acid Two molecules of linear dsRNA of MW $\approx 1.49$ and $1.38 \mathrm{x}$ $10^{6} ; \approx 24 \%$ by weight of the virus.

Protein Not characterized.

Lipid None reported.

Carbohydrate None reported.

Antigenic Present members are serologically related. properties

\section{OTHER MEMBERS}

Carrot temperate 2

Hop trefoil cryptic 2

Red clover cryptic 2

Possible member

Alfalfa cryptic 2 


\section{REFERENCES}

Abou-Elnasr, M.A.; Jones, A.T.; Mayo, M.A.: Detection of dsRNA in particles of vicia cryptic virus and in Vicia faba tissues and protoplasts. J. gen. Virol. 66:2453-2460 (1985).

Accotto, G.P.; Boccardo, G.: The coat proteins and nucleic acids of two beet cryptic viruses. J. gen. Virol. 67:363-366 (1986).

Accotto, G.P.; Brisco, M.J.; Hull, R.: In vitro translation of the double-stranded RNA genome from beet cryptic virus 1. J. gen. Virol. 68:1417-1422 (1987).

Antoniw, J.F.; Linthorst, H.J.M.; White, R.F.; Bol, J.F.: Molecular cloning of the doublestranded RNA of beet cryptic viruses. J. gen. Virol. 67:2047-2051 (1986).

Boccardo, G.; Accotto, G.P.: RNA-dependent RNA polymerase activity in two morphologically different white clover cryptic viruses. Virology 163: 413-419 (1988).

Boccardo, G.; Lisa, V.; Luisoni, E.; Milne, R.G.: Cryptic plant viruses. Adv. Virus Res. 32:171-214 (1987).

Boccardo, G.; Milne, R.G.; Luisoni, E.; Lisa, V.; Accotto, G.P.: Three seedborne cryptic viruses containing double-stranded RNA isolated from white clover. Virology 147:29-40 (1985).

Kassanis, B.; White, R.F.; Woods, R.D.: Beet cryptic virus. Phytopath. Z. 90:350-360 (1977).

Luisoni, E.; Milne, R.G.; Accotto, G.P.; Boccardo, G.: Cryptic viruses in hop trefoil (Medicago lupulina) and their relationships to other cryptic viruses in legumes. Intervirology 28: 144-156 (1987).

Marzachi, C.; Milne, R.G.; Boccardo, G.: In vitro synthesis of double-stranded RNA by carnation cryptic virus-associated RNA-dependent RNA polymerase. Virology 165: 115121 (1988).

Natsuaki, T.; Natsuaki, K.T.; Okuda, S.; Teranaka, M.; Milne, R.G.; Boccardo, G.; Luisoni, E.: Relationships between the cryptic and temperate viruses of alfalfa, beet and white clover. Intervirology 25:69-75 (1986).

Natsuaki, T.; Yamashita, S.; Doi, Y.; Okuda, S.; Teranaka, M.: Two seed-borne doublestranded RNA viruses, beet temperate virus and spinach temperate virus. Ann. Phytopathol. Soc. Jpn. 49:709-712 (1983).

Xie, W.; Antoniw, J.F.; White, R.F.: Detection of beet cryptic viruses 1 and 2 in a wide range of beet plants using cDNA probes. Plant Pathology 38: 527-533 (1989). 
Morphology

Physicochemical properties

Nucleic acid

Protein

Lipid and Carbohydrate

Antigenic properties

Effect on cells

\section{Properties of the Virus Particle}

Spherical. 60-70 $\mathrm{nm}$ in diameter, with an envelope tightly applied to a proven or presumed icosahedral nucleocapsid 35-40 $\mathrm{nm}$ in diameter. Surface projections are demonstrable in most togaviruses.

$S_{20 w}=280 ;$ buoyant density in sucrose, $1.2 \mathrm{~g} / \mathrm{cm}^{3}$.

Single molecule of positive-sense ssRNA, MW $=4 \times 10^{6}$; $8-9 \%$ by weight of virus. Where characterized, genes for nonstructural proteins are located at the $5^{\prime}$ end. The $5^{\prime}$ terminus is capped, and the 3 ' end is polyadenylated.

Two or three envelope proteins, one or more of which are glycosylated, and a smaller core protein.

The virus-specific glycoproteins are inserted in the lipoprotein envelope, whose lipids are cell-derived.

Members of a genus are antigenically related to each other but not to members of other genera of the family.

Members of the genera Alphavirus and Rubivirus show ion-dependent hemagglutinating activity.

\section{REPLICATION}

Multiply in cytoplasm and have been shown or are presumed to mature by budding. Structural proteins are translated from subgenomic mRNAs.

\section{Biological Aspects}

\section{Host range}

Transmission
All species of the genus Alphavirus replicate in arthropod vectors as well as in a wide range of vertebrates.

Members of the genera Rubivirus and Arterivirus, and other possible members of the family, are not arthropodborne.

\section{GENERA}

Arbovirus group A

Rubella virus

Equine arteritis virus
Alphavirus

Rubivirus

Arterivirus 


\begin{tabular}{llc}
\hline \hline GENUS & ARBOVIRUS GROUP A & ALPHAVIRUS \\
\hline TYPE SPECIES & SINDBIS VIRUS & - \\
\hline
\end{tabular}

Properties of the Virus Particle

Morphology

Overall diameter of $70 \mathrm{~nm}$; glycoprotein subunits are arranged in trimer clusterings of E1-E2 heterodimers to form icosahedral particles with $\mathrm{T}=4$. In most preparations, only the surface fringe of spikes is visible by negative staining. The lipid bilayer of the virus envelope is polyhedral and surrounds a smooth $\mathrm{T}=3$ nucleocapsid.

Physicochemical $M W \approx 46 \times 10^{6} ; S_{20 w} \approx 280$; buoyant density in sucrose properties $1.2 \mathrm{~g} / \mathrm{cm}^{3}$.

Nucleic acid

$\mathrm{MW} \approx 4 \times 10^{6}(12 \mathrm{~kb})$ capped (type 0 cap) and polyadenylated; $8.7 \%$ by weight of particle. The gene order is 5'-nsPl-nsP2-nsP3-nsP4-C-E3-E2-E1-3', established by nucleotide sequen'cing. RNAs of 5 viruses have been sequenced completely.

Protein

The capsid protein $\mathrm{C}\left(\mathrm{MW} \approx 30 \times 10^{3}\right)$, and two envelope glycoproteins E1 and E2 (MW = 50-59 x 103), plus glycoprotein $\mathrm{E} 3\left(\mathrm{MW} \approx 10 \times 10^{3}\right)$ in some members. These comprise $60-64 \%$ by weight of particle.

\section{Lipid}

Carbohydrate
$27-31 \%$ by weight located in the viral membrane, derived from the host cell.

$7 \%$ by weight located in the viral membrane. Both high mannose and complex glycans are $\mathrm{N}$-linked to the envelope glycoproteins.

E1 and E2 function as a heterodimer, but most neutralizing monoclonal antibodies are directed against E2. Members may be assigned to one of at least seven antigenic complexes, each comprising one or more species.

\section{REPLICATION}

Virions mature by budding of preassembled nucleocapsids through the plasma membrane. A full length minus strand RNA is synthesized by the virus-coded polymerase (nonstructural proteins); this RNA provides the template for synthesis of progeny genome and the subgenomic $26 \mathrm{~S}$ messenger RNA $(\approx 4.1 \mathrm{~kb})$ representing the $3^{\prime}$ terminal one-third of the genomic RNA. These RNA species are synthesized under independent regulation in membranous cytoplasmic membranes. Mapping of temperature sensitive 
mutants has shown that all four nonstructural proteins nsP1 - nsP4 $\left(\mathrm{MW}=60-90 \times 10^{3}\right)$ are required for RNA replication. These are generated from the $5^{\prime}$ end of genomic RNA (a minor messenger) as a polyprotein which is post-translationally cleaved by a proteinase in $\mathrm{ns} \mathrm{P} 2$ that acts primarily in trans.

Three of them, nsP1, nsP2, and nsP4, share sequence homology with nonstructural proteins of several groups of plant viruses, including tobamoviruses (tobacco mosaic virus), suggesting a common origin for the replicase of these viruses. The structural proteins are translated from the amplified and capped subgenomic messenger, commencing with the $\mathrm{C}$ protein which is cleaved first, autocatalytically, from the nascent polyprotein. The translation of $\mathrm{C}$ is followed by that of PE2 (subsequently cleaved to E3 and E2), and E1; PE2 and E1 are inserted into the endoplasmic reticulum via signal sequences and are glycosylated, and fatty acid acylated, during passage to the Golgi apparatus and the plasma membrane. Translation of host cell messengers is inhibited during infection of permissive vertebrate cell cultures, but not during infection of mosquito cells.

\title{
OTHER MEMBERS
}

\author{
Aura \\ Barmah Forest \\ Babanki \\ Bebaru \\ Buggy Creek \\ Chikungunya \\ Eastern equine encephalitis \\ Everglades \\ Fort Morgan \\ Getah \\ Highlands J \\ Kyzylagach \\ Mayaro \\ Middelburg \\ Mucambo \\ Ndumu \\ Ockelbo \\ O'nyong-nyong \\ Pixuna \\ Ross River \\ Sagiyama \\ Semliki Forest \\ Una
}


Venezuelan equine encephalitis

Western equine encephalitis

Whataroa

\begin{tabular}{llc}
\hline \hline GENUS & RUBELLA VIRUS & RUBIVIRUS \\
\hline TYPE SPECIES & RUBELLA VIRUS & - \\
\hline
\end{tabular}

\section{Properties of The Virus Particle}

Morphology Virions $60 \mathrm{~nm}$ in diameter.

Physicochemical Similar to the Alphavirus genus but serologically properties unrelated. Only the type species recognized so far.

Nucleic acid MW $=3.4 \times 10^{6}$, comprising 9755 nucleotides, capped and polyadenylated. The gene order is $5^{\prime}$ nonstructural (replicase) proteins/C-E2-E1 3'.

Protein

Structural proteins comprise two glycoproteins, E1 (MW = $\left.58-59 \times 10^{3}\right)$ and E2 $\left(\mathrm{MW}=42-48 \times 10^{3}\right.$ ) (size range represents heterogeneous glycosylation) and a capsid protein $\mathrm{C}\left(\mathrm{MW}=33-34 \times 10^{3}\right)$. High mannose and complex glycans are $\mathrm{N}$-linked to E1 and E2. The three proteins are cleaved from a polyprotein translated from a subgenomic $24 \mathrm{~S}$ mRNA; the order of translation is $\mathrm{NH}_{2}-$ C-E2-E1-COOH.

\section{REPLICATION}

Virus matures by budding through intracytoplasmic membranes or the plasma membrane. A $24 \mathrm{~S}$ mRNA $(\approx$ $3.3 \mathrm{~kb}$ ) is synthesized during infection, probably using a full-length minus strand RNA as template. The structural proteins are synthesized from this amplified, capped and polyadenylated subgenomic mRNA, commencing with the $\mathrm{C}$ protein, followed by E2 and E1. Cleavage occurs cotranslationally. E2 and E1 are inserted via independent signal sequences in the endoplasmic reticulum, where they are $\mathrm{N}$-glycosylated. Host cell protein synthesis is not inhibited during infection.

\section{Biological Aspects}

Host range No invertebrate host; man is the only known vertebrate host.

Transmission Spread principally by aerosolization, but congenital transmission can occur. 


\begin{tabular}{llc}
\hline \hline GENUS & EQUINE ARTERITIS VIRUS & ARTERIVIRUS \\
\hline TYPE SPECIES & EQUINE ARTERITIS VIRUS & - \\
\hline
\end{tabular}

\section{Properties of The Virus Particle}
Morphology Virions are $60 \mathrm{~nm}$ diameter with $12-15 \mathrm{~nm}$ ring-like subunits on the surface.

Physicochemical Similar to those of Alphavirus. properties

Nucleic acid $\quad M W \approx 4 \times 10^{6}(\approx 12.7 \mathrm{~kb})$; polyadenylated. At least six open reading frames have been identified by nucleotide sequencing. The capsid gene is located at the $3^{\prime}$ end of the genome.

\section{Protein}

Structural proteins comprise a glycosylated envelope protein $\mathrm{E} 1\left(\mathrm{MW} \approx 21 \times 10^{3}\right)$, a nonglycosylated $\mathrm{E} 2(\mathrm{MW} \approx$ $\left.14 \times 10^{3}\right)$ and a core protein $\mathrm{C}\left(\mathrm{MW} \approx 12 \times 10^{3}\right)$.

\section{REPLICATION}

Maturation occurs by budding through cytoplasmic membranes into cisternae. In addition to the genome, five polyadenylated RNA species $\left(\mathrm{MW}=0.2-1.0 \times 10^{6}\right)$ are synthesized in infected cells. These subgenomic RNAs, which may be derived from a larger precursor RNA, form a 3'-terminal nested set and contain a common leader sequence of about 208 nucleotides. The leader sequences on the subgenomic RNAs are identical to the sequence at the 5 ' end of the genome. The smallest subgenomic RNA encodes the capsid protein and the other RNAs probably all function as mRNAs. Translation of the $5^{\prime}$ unique region of the genome (i.e. not present in any of the subgenomic RNAs) involves ribosomal frameshifting.

\section{Biological ASPects}

Host range Equines are the only hosts, and the single virus species is distributed world wide, producing symptoms associated with characteristic necrosis in muscle cells of small arteries, and abortion in pregnant mares.

Transmission Vertical and horizontal.

\section{NOTE ON Classification}

The presence of a nested set of subgenomic mRNAs with a common leader sequence, and a 3'-terminal capsid protein 
gene, suggests that the arteriviruses are more closely related to the coronaviruses than to the togaviruses. In the future these viruses will almost certainly be reclassified either as a genus in the Coronaviridae or in a new family Arteriviridae.

\section{OTHER MEMBERS}

\section{Possible members}

Carrot mottle virus

Lactic dehydrogenase

Derivation of Names toga: from Latin toga, 'gown, cloak' alpha: from Greek letter 'A'. rubi: from Latin rubeus, 'reddish'. arteri: from equine arteritis, the disease caused by type member virus

\section{REFERENCES}

Calisher, C.H.; Karabatsos, N.: Arbovirus serogroups: definition and geographic distribution. In Monath, T.P. (ed.), The arboviruses: epidemiology and ecology, Vol. 1, pp. 19-57 (CRC Press, Boca Raton, Fl., 1988).

de Vries, A.A.F.; Chirnside, E.D.; Bredenbeek, P.J.; Gravestein, L.A.; Horzinek, M.C.; Spaan, W.J.M.: A common leader sequence is spliced to all subgenomic mRNAs of equine arteritis virus. Nuc. Acids Res. 18:3241-3247 (1990).

Dominguez, G.; Wang, C.-Y.; Frey, T.K.: Sequence of the genomic RNA of rubella virus: Evidence for genetic rearrangement during togavirus evolution. Virology 177:225-238 (1990).

Frey, T.K.; Marr, L.D.: Sequence of the region coding for virion proteins C and E2 and the carboxy terminus of the nonstructural proteins of rubella virus: Comparison with alphaviruses. Gene 62: 85-99 (1988).

Fuller, S.D.: The $\mathrm{T}=4$ envelope of Sindbis virus is organized by interactions with a complementary $\mathrm{T}=3$ capsid. Cell 48:923-934 (1987).

Grakoui, A.; Levis, R.; Raju, R.; Huang, H.V.; Rice, C.M.: A cis-acting mutation in the Sindbis virus junction region which affects subgenomic RNA synthesis. J. Virol. 63: 5216-5227 (1989).

Hahn, Y.S.; Strauss, E.G.; Strauss, J.H.: Mapping of RNA-temperature-sensitive mutants of Sindbis virus: Assignment of complementation groups A, B and G to nonstructural proteins. J. Virol. 63: 3142-3150 (1989).

Hardy, W.R.; Strauss, J.H.: Processing the nonstructural polyproteins of Sindbis virus: Nonstructural proteinase is in the C-terminal half of nsP2 and functions both in cis and in trans. J. Virol. 63: 4653-4664 (1989).

Karabatsos, N.: International catalogue of arboviruses. 3rd edn. (American Society of Tropical Medicine and Hygiene, San Antonio, 1985).

Pettersson, R.F.; Oker-Blom, C.; Kalkkinen, N.; Kallio, A.; Ulmanen, I.; Kaariainen, L.; Partanen, P.; Vaheri, A.: Molecular and antigenic characteristics and synthesis of rubella virus structural proteins. Rev. Infect. Dis. 7:S140-S149 (1985). 
Schlesinger, S.; Schlesinger, M.J.: The Togaviridae and Flaviviridae (Plenum Press, New York, 1985).

Spaan, W.J.M.; den Boon, J.A.; Bredenbeek, P.J.; et al.: Comparative and evolutionary aspects of coronaviral, arteriviral, and togaviral genome structure and expression. In Brinton, M.A.; Heinz, F.X. (eds.), Positive stranded RNA viruses (American Society for Microbiology, Washington, D.C., 1990).

Strauss, E.G.; Rice, C.M.; Strauss, J.H.: Complete nucleotide sequence of the genomic RNA of Sindbis virus. Virology 133: 92-110 (1984).

Strauss, J.H.; Strauss, E.G.: Evolution of RNA viruses. Annu. Rev. Microbiol. 42: 657-683 (1988).

Takkinen, K.; Vidgren, G.; Ekstrand, J.; Hellman, U.; Kalkkinen, N.; Wernstedt, C.; Pettersson, R.F.: Nucleotide sequence of the rubella virus capsid protein gene reveals an unusually high G/C content. J. gen. Virol. 69: 603-612 (1988).

Theiler, M.; Downs, W.G.: The arthropod-borne viruses of vertebrates (Yale University Press, New Haven, 1973).

van Berlo, M.F.; Rottier, P.J.M.; Spaan, W.J.M.; Horzinek, M.C.: Equine arteritis virusinduced polypeptide synthesis. J. gen. Virol. 67:1543-1549 (1986).

Westaway, E.G.; Brinton, M.A.; Gaidamovich, S.Ya.; Horzinek, M.C.; Igarashi, A.; Kaariainen, L.; Lvov, D.K.; Porterfield, J.S.; Russell, P.K.; Trent, D.W.: Togaviridae. Intervirology 24:125-139 (1985). 
Morphology

Physicochemical properties

Nucleic acid

Protein

Lipid and carbohydrate

Antigenic properties

\section{Properties of The Virus Particle}

Spherical $40-60 \mathrm{~nm}$ in diameter; enveloped.

$S_{20 w}=140-200$.

A single molecule of infectious ssRNA. No poly(A) tract at the $3^{\prime}$-end. A single long ORF codes for a polyprotein which is processed into all the virus-coded proteins. Structural and nonstructural proteins derived from the 5'and 3'-terminal sequences, respectively.

Two or three membrane-associated proteins and a core protein.

The membrane-associated proteins are inserted in the lipoprotein envelope, whose lipids are cell derived.

Members of each genus are serologically related to each other but not to members of the other genera.

\section{REPLICATION}

Multiply in cytoplasm in association with membranes and mature into cytoplasmic vesicles. Replication commonly accompanied by a characteristic proliferation of intracellular membranes. The only viral messenger is the genome.

\section{Genera}

Arbovirus group B Flavivirus Mucosal disease virus group Pestivirus Hepatitis $\mathrm{C}$ virus group

\begin{tabular}{llc}
\hline \hline GENUS & ARBOVIRUS GROUP B & FLAVIVIRUS \\
\hline TYPE SPECIES & YELLOW FEVER VIRUS & - \\
\hline
\end{tabular}

Properties of the Virus Particle

Morphology Spherical, $40-50 \mathrm{~nm}$ in diameter with an envelope tightly applied to a spherical core $25-30 \mathrm{~nm}$ in diameter. Surface projections are demonstrable. 
Taxonomic status

Physiological properties

Nucleic acid

\section{Protein}

\section{Lipid and carbohydrate}

\section{Antigenic properties}

English vernacular name

International name

$\mathrm{S}_{20 \mathrm{w}}=170-210$; buoyant density in $\mathrm{CsCl}=1.22-1.24$ $\mathrm{g} / \mathrm{cm}^{3}$ and $1.15-1.20 \mathrm{~g} / \mathrm{cm}^{3}$ in sucrose.

$\mathrm{MW} \approx 4 \times 10^{6}(\approx 11 \mathrm{~kb})$. Capped at the 5'-end; no poly(A) tract at $3^{\prime}$ end. The gene order is $5^{\prime}-\mathrm{C}$-preM-ENS1-ns2a-ns2b-NS3-ns4a-ns4b-NS5-3', established by nucleotide and partial amino acid sequence determination.

Since flaviviruses mature into cytoplasmic vesicles two types of virus particles can be defined: cell-associated virus and extracellular virus. Extracellular virus contains two envelope proteins $\mathrm{E}$ and $\mathrm{M}$ and an internal RNA-associated protein $C$. Instead of the $M$ protein cell-associated virus particles contain a larger precursor protein pre $M$ which is cleaved during or shortly after release of virus from infected cells; only the carboxy-terminal part of preM remains associated to the extra-cellular virus particle as $M$ protein. The $\mathrm{E}$ membrane protein $\left(\mathrm{MW}=51-59 \times 10^{3}\right)$ is usually glycosylated. It contains twelve conserved cysteine residues which form six disulfide bridges. The $M$ membrane protein $\left(\mathrm{MW}=7-9 \times 10^{3}\right)$ is an unglycosylated protein containing no disulfide bridges. The preM protein $\left(\mathrm{MW}=20-24 \times 10^{3}\right)$ is glycosylated containing six disulfide bridges. The $\mathrm{C}$ core protein $\left(\mathrm{MW}=14-16 \times 10^{3}\right)$ is rich in arginine and lysine throughout its complete primary sequence.

About $17 \%$ and $9 \%$ by weight, respectively. Located in the viral membrane. The carbohydrate moieties of $\mathrm{E}$ comprise both high mannose and complex glycans.

A structural model of protein $\mathrm{E}$ assigns monoclonal antibody-defined antigenic domains and epitopes to distinct sequence elements and protein domains; these induce antibodies with type or subtype, complex, or group reactivity, measurable by ELISA, RIA, immunofluorescence, virus neutralization, passive protection, inhibition of haemagglutination, or enchancement of infectivity.

\section{REPLICATION}

In cytoplasm, associated with proliferation of rough and smooth endoplasmic reticulum forming organelles; no nucleocapsids identified in cells and virus particles accumulate within lamellae and vesicles. RNA replication occurs in foci in the perinuclear region through a minus strand intermediate. The only messenger is the genomic RNA, which is translated into a polyprotein from a single open reading frame on membrane-bound polysomes. 
Polyprotein processing has been difficult to observe in infected cells but has been studied in cell-free translation systems. The structural proteins are $\mathrm{N}$-terminal in the order C, pre M and E. Signal peptidase is believed to make the three cleavages that separate the structural proteins. The nonstructural proteins NS1 (a glycoprotein), NS2A, NS2B, NS3, NS4A, NS4B, and NS5 follow. At least three, and probably four, of the cleavages to separate these proteins are made by a trypsin-like proteinase present in the $\mathrm{N}$-terminus of NS3; signal paptidase probably makes the two other cleavages required to separate the nonstructural proteins. NS3 and NS5 are believed to be components of the RNA replicase. In vertebrate cells, the latent period is $12-16 \mathrm{~h}$ and virus production continues over 3-4 days. Host cell RNA and protein synthesis continue throughout infection.

\section{Biological Aspects}

Natural host range

Transmission

Pathogenicity

Experimental hosts
Most members are arboviruses, maintained in nature by bidirectional transfer between haematophagous arthropod vectors (either mosquitoes or ticks, not both) and vertebrate hosts (mammals or birds). Replicate in susceptible species of both phyla. Some viruses have limited vertebrate host range (e.g. only human and simian), for others it can cover a wide variety. The nonarbovirus members of the genus have been isolated either from arthropods or from vertebrates, not both.

The majority are transmitted by arthropod bite; transovarial transmission in arthropods has been demonstrated for some members, as has transplacental and horizontal transmission in vertebrates.

For arthropods essentially none. In vertebrates highly variable: about 30 viruses cause disease in man, varying from febrile illnesses, rashes, to life-threatening, such as hemmorrhagic fevers, encephalitis, hepatitis. Some 8 to 10 cause severe and economically important disorders in domestic animals.

Initial isolation in mice (preferably newborn) by intercranial inoculation; after "adaptation", many other hosts may be susceptible. In certain inbred mouse strains, a single dominant gene determines resistance specific for flaviviruses. Genetic resistance associated with generation of DI RNAs and particles. Arthropods can be infected with some by feeding or inoculation. 
Taxonomic status

Cell structures

Haemagglutination
English vernacular name

International name

Many vertebrate and arthropod cells support replication, some with, others without CPE or plaque formation or syncytium formation in arthropod cell cultures. Persistent infection is common.

Red blood cells from adult geese or 1-2 day-old chicks are agglutinated optimally at slightly acid $\mathrm{pH}$.

\section{OTHER MEMBERS}

Based on cross neutralization tests with single polyclonal hyperimmune mouse ascitic fluids prepared against each of the viruses listed, except where indicated otherwise. "Unassigned" denotes viruses which gave no significant cross neutralization in these experiments but are designated as flaviviruses on basis of some serological cross-reaction with at least one accepted member of the genus.

\section{SUBGROUP NAME OF VIRUS}

Tick-borne Tick-borne encephalitis (European encephalitis subtype and Far Eastern subtype)

Omsk hemorrhagic fever

Louping ill

Kyasanur forest disease

Langat

Negishi

Powassan

Karshi

Royal farm

Carey Island

Phnom Penh bat (no known vector).

Rio Bravo

Rio Bravo

Entebbe bat

Dakar bat

Bukalasa bat

Saboya

Apoi (no known vector).

Japanese Japanese encephalitis

encephalitis Murray Valley encephalitis

Kokobera

Alfuy

Stratford

St. Louis encephalitis

Usutu

West Nile

Kunjin

Koutango (all mosquito-borne). 

Tyuleniy Tyuleniy
Saunarez Reef
Meaban (all tick-borne) (based on CF tests).

Ntaya
Uganda
Dengue

Modoc
Ntaya

Tembusu

Yokase

Israel turkey meningoencephalitis

Bagaza (all mosquito-borne).

\section{Uganda $S$}

Banzi

Bouboui

Edge Hill (all mosquito-borne).

Dengue types $1,2,3,4$ (all mosquitoborne).

\section{Modoc}

Cowbone Ridge

Jutiapa

San Vieja

San Perlita (no known vectors).

Unassigned Gadget's Gully

Kadam (tick-borne)

Bussuquara

Ilheus

Jugra

Naranjal

Rocio

Sepik

Spondweni

Yellow fever

Zika

Wesselsbron (all mosquito-borne)

Aroa

Cacipacore

Montana myotis leukoencephalitis

Sokoluk

Tamana bat (no known vectors). 


\begin{tabular}{llc}
\hline \hline GENUS & MUCOSAL DISEASE & PESTIVIRUS \\
& VIRUS GROUP & - \\
\hline TYPE SPECIES & $\begin{array}{l}\text { BOVINE VIRAL DIARRHEA } \\
\text { VIRUS (BVDV) } \\
\text { (MUCOSAL DISEASE VIRUS) }\end{array}$ \\
\hline
\end{tabular}

\section{Properties of the Virus Particle}

Morphology

Physicochemical properties

Nucleic acid

Protein

Lipid and carbohydrate

Antigenic properties
Spherical, 40-60 $\mathrm{nm}$ in diameter with an envelope containing 10-12 nm ring-like subunits on the surface.

$S_{20 w} \approx 140 ;$ buoyant density in sucrose $=1.12-1.13$ $\mathrm{g} / \mathrm{cm}^{3}$.

$\mathrm{MW} \approx 4.3 \times 10^{6},(\approx 12.5 \mathrm{~kb})$. The $5^{\prime}$-end has not yet been characterized; no poly(A) tract at 3 '-end. Sequencing reveals a single large ORF encoding a poly-protein of about 4,000 amino acids. The tentative gene order is 5'-p20-gp48-gp25-gp55-p125-(p54/p80)-p10-X(unidentified)-p133(p58/p75)-3', established by sequencespecific antibody reactivities. For cytopathic biotypes of BVDV, a small and variable segment of host cell nucleic acid may be integrated into one particular region (p54) of the viral genome. This insertion maintains the ORF.

Establishment of "structural" proteins is not yet conclusive. There are three viral glycoproteins ( $M W=53$ $57 \times 10^{3}, 44-48 \times 10^{3}$, and 23-31 $\times 10^{3}$ ) probably in the virus envelope. The core protein is likely to be the first (amino terminal) polypeptide of the polyprotein ( $\mathrm{MW}=$ 20-31 x 103). The hydrophobicity plot of BVDV exhibits a pattern very similar to that seen in most flaviviruses.

No reports have described the lipid composition. Virus glycoproteins contain $\mathrm{N}$-linked glycans.

Monoclonal antibodies reactive with at least one virus glycoprotein $\left(\mathrm{MW}=55-57 \times 10^{3}\right)$ neutralize virus infectivity. A conserved, immunodominant nonstructural protein $\left(\mathrm{MW} \approx 80 \times 10^{3}\right.$ ) probably represents the virus "soluble antigen".

\section{REPLICATION}

Replication occurs in association with membranes. Replication is uniquely sensitive to proflavine and acriflavine. No subgenomic mRNA is found in infected cells. The genomic RNA is believed to be translated into a polyprotein that is rapidly processed cotranslationally and 
post-translationally, although translation initiation at sites other than the first methionine of the open reading frame has not been ruled out. Differences exist in polyprotein processing by noncytopathic and cytopathic biotypes of BVDV. Both cellular and virus-encoded proteinases are probably involved in polyprotein processing. Candidate virus proteins possessing proteolytic activity for cytopathic BVDV are p20 $\left(\mathrm{MW} \approx 20 \mathrm{x} 10^{3}\right)$ and $\mathrm{p} 80(\mathrm{MW} \approx 80 \mathrm{x}$ $\left.10^{3}\right)$. Based on sequence comparisons, proteins p125 (p54/p80) and p133 (p58/p75) are believed to be components of the RNA replicase. Host cell RNA and protein synthesis continue throughout infection.

\section{Biological Aspects}

Host range

Transmission

Pathogenicity

Experimental hosts

Cell structures

Haemagglutination
All members have a limited host range (mammals). No invertebrate hosts.

No known vectors. Field spread occurs by direct and indirect contact (e.g. faecal contaminated feed, urine, nasal secretions) and by transplacental and congenital transmission.

Highly variable; including inapparent infection, acute or persistent subclinical infection, acute fatal disease (mucosal disease), fetal death or congenital abnormalities, and chronic wasting disease. In mucosal disease, two natural virus biotypes (cytopathic and noncytopathic) must collaborate to induce fatal disease. Pestivirus infections of domestic animals represent economically important disease situations worldwide.

No experimental infection models have been established outside the natural mammalian hosts.

Only cells derived from host species (bovine, porcine, ovine) support virus replication. Most virus isolates do not cause CPE. Many cause persistent infections of cell cultures. For BVDV, cytopathic viruses are routinely identified capable of plaque formation and extensive CPE.

No hemagglutinating activity has been found associated with pestiviruses.

\section{OTHER MEMBERS}

Border disease (of sheep)

Hog cholera (European swine fever) 


\begin{tabular}{lll}
\hline \hline GENUS & HEPATITIS C VIRUS GROUP & - \\
\hline TYPE SPECIES & HEPATITIS C VIRUS (HCV) & - \\
\hline
\end{tabular}

\section{Properties of the virus Particle}

Morphology

Physicochemical properties

\section{Nucleic acid}

Protein

\section{Lipid and carbodydrates}

Virus particles have not been visualized by electron microscopy. Virus is enveloped or lipid-containing (inferred from chloroform-sensitivity). Virus diameter estimated to be $40-60 \mathrm{~nm}$ extrapolated from filtration and chimpanzee titration studies.

$S_{20 w} \geq 150$; buoyant density in sucrose $=1.09-1.11$ $\mathrm{g} / \mathrm{cm}^{3}$. Stable in TEN buffer $(0.05 \mathrm{M}$ Tris, $0.001 \mathrm{M}$ EDTA, $0.1 \mathrm{M} \mathrm{NaCl}$ ) at $\mathrm{pH}$ 8.0-8.7.

$\mathrm{MW} \approx 3.5 \times 10^{6}(\approx 10 \mathrm{~kb})$. The entire genome has been sequenced; a sequence containing 7310 bases located near the 3 '-end of the genome has been published (European patent EPO No. 318,216). Single ORF encodes a polyprotein of about 3000 amino acids. No poly(A) tract at terminal 3'-end but several poly(A) rich regions located near 3'-end. The tentative gene order of HCV (inferred from comparative analysis of published sequence and unreported characterization of putative structural gene sequence) (M. Houghton, personal communication) is: 5'C-preM/E-NS1-NS2A-NS2B-NS3-NS4A-NS4B-NS5-3', where $\mathrm{preM} / \mathrm{E}$ may represent a fusion of preM and $\mathrm{E}$ or a more conventional preM and a truncated $\mathrm{E}$ protein peculiar to HCV. Several flavivirus-like concensus sequences are found in $\mathrm{HCV}$, including GXGGXP (amino terminus of HCV-"NS3"), and GDD, a sequence found in the HCV"NS5" protein that (by comparison to other single-stranded RNA viruses) probably represents the viral RNAdependent RNA polymerase.

The existence of "structural" proteins has not been established by conventional gene mapping and Western blot techniques. Putative NS2AB, NS3, NS4AB and NS5 proteins have $\mathrm{MW} \approx 41,62,42$ and $101 \times 10^{3}$, respectively, based on hydrophobicity plots and location of known cleavage sites in flavivirus polyproteins. The hydrophobicity plot of HCV exhibits a pattern very similar to that seen in most flaviviruses.

None reported. 
Antigenic properties

Host range

Transmission

Pathogenicity

Experimental hosts

Cell culture
A highly conserved nonstructural protein (derived from the putative NS4 region and expressed as a fusion protein) has been shown to identify virus-specific antibodies in a wide variety of individuals infected with HCV. No other epitopes or expressed antigens have been described to date.

\section{REPLICATION}

Replication appears to occur within hepatocyte cytoplasm of experimentally infected chimpanzees and involves a conspicuous proliferation of endoplasmic reticulum and formation of characteristic ultrastructural alterations. Some of these structures, including convoluted membranes and dense reticular inclusion bodies, mimic those found in cells infected by known flaviviruses. No subgenomic RNA has been detected in infected liver tissues by Northern blot analysis.

\section{BIOLOGICAL ASPECTS}

Man is the natural host and apparent reservoir of HCV. No other natural host has been identified.

Approximately $5-10 \%$ of all disease caused by $\mathrm{HCV}$ occurs as a result of blood transfusion. About $40 \%$ of cases of acute sporadic $\mathrm{HCV}$ infection have a history of i.v. drug abuse. One half of all other cases do not have any apparent risk of parenteral exposure. Serologic studies of blood donors for virus-specific antibody suggest that about $0.5-1.0 \%$ are infected with HCV. About one third of all acute hepatitis in the US is caused by HCV.

Highly variable, ranging from inapparent subclinical infection to fulminant disease resulting in hepatic failure and death. Persistent infection occurs in approximately $60 \%$ of HCV infected individuals and approximately $20 \%$ develop chronic active hepatitis and/or cirrhosis. Persistent HCV infection has been serologically linked to primary liver cancer, cryptogenic cirrhosis, and some forms of autoimmune disease.

The chimpanzee remains the only proven model of experimental $\mathrm{HCV}$ infection.

None reported.

\section{Possible Members}

Aedes albopictus cell fusing agent

Simiam hemorrhagic fever virus. 
Derivation of flavi: from Latin flavus, 'yellow'

Name pesti: from Latin pestis, 'plague'

\section{REFERENCES}

Bradley, D.W.; McCaustland, K.A.; Cook, E.H.; Schable, C.A.; Ebert, J.W.; Maynard, J.E.: Post-transfusion non-A, non-B hepatitis in chimpanzees; physicochemical evidence that the tubule-forming agent is a small, enveloped virus. Gastroenterology 88: 773-779 (1985).

Calisher, C.H.; Karabatsos, N.; Dalrymple, J.M.; Shope, R.E.; Porterfield, J.S.; Westaway, E.G.; Brandt, W.E.: Antigenic relationships between flaviviruses as determined by cross-neutralization tests with polyclonal antisera. J. gen. Virol. 70: 37-43 (1989).

Chamberlain, R.W.: Epidemiology of arthropod-borne viruses: the role of arthropods as hosts and vectors and of vertebrate hosts in natural transmission cycles. In: Schlesinger, R.W. (ed.), The Togaviruses, pp. 175-227 (Academic Press, New York, 1980).

Choo, Q.L.; Kuo, G.; Weiner, A.J.; Overby, L.R.; Bradley, D.W.; Houghton, M.: Isolation of a cDNA clone derived from a blood-borne non-A, non-B viral hepatitis genome. Science 244: 359-362 (1989).

Collett, M.S.; Larson, R.; Gold, C.; Strick, D.; Anderson, D.K.; Purchio, A.F.: Molecular cloning and nucleotide sequence of the pestivirus bovine viral diarrhea virus. Virology 165: 191-199 (1988).

Collett, M.S.; Moennig, V.; Horzinek, M.C.: Recent advances in pestivirus research. J. gen. Virol. 70: 253-266 (1989).

Gorbalenya, A.E.; Donchenko, A.P.; Koonin, E.V.; Blinov, V.M.: N-terminal domains of putative helicases of flavi- and pestiviruses may be serine proteases. Nuc. Acids Res. 17: 3889-3897 (1989).

Heinz, F.X.: Epitope mapping of flavivirus glycoproteins. Adv. Virus Res. 31: 103-168 (1986).

Igarashi, A.; Harrap, K.A.; Casals, J.; Stollar, V.: Morphological, biochemical and serological studies on a viral agent (CFA) which replicates in and causes fusion of Aedes albopictus (Singh) cells. Virology 74:174-187 (1976).

Karabatsos, N.: International catalogue of arboviruses, 3rd edn. (American Society of Tropical Medicine and Hygiene, San Antonio, 1985).

Mandl, C.W.; Guirakhoo, F.; Holzmann, H.; Heinz, F.X.; Kunz, C.: Antigenic structure of the flavivirus envelope protein $\mathrm{E}$ at the molecular level, using tick-borne encephalitis virus as a model. J. Virol. 63: 564-571 (1989).

Meyers, G.; Rumenapf, T.; Thiel, H.-J.: Molecular cloning and nucleotide sequence of the genome of hog cholera virus. Virology 171: 555-567 (1989).

Meyers, G.; Rumenapf, T.; Thiel, H.-J.: Ubiquitin in a togavirus. Nature 341: 491 (1989).

Murphy, F.A.: Togavirus morphology and morphogenesis. In Schlesinger, R.W. (ed.),. The Togaviruses, pp. 241-316 (Academic Press, New York, 1980).

Nowak, T.; Farber, P.M.; Wengler, G.: Analyses of the terminal sequences of West Nile virus structural proteins and of the in vitro translation of these proteins allow the proposal of a complete scheme of the proteolytic cleavages involved in their synthesis. Virology 169: 365-376 (1989).

Rice, C.M.; Grakoui, A.; Galler, R.; Chambers, T.J.: Transcription of infectious yellow fever virus RNA from full-length cDNA templates produced by in vitro ligation. New Biol. 1: 285-296 (1989).

Rice, C.M.; Lenches, E.M.; Eddy, S.R.; Shin, S.J.; Sheets, R.L.; Strauss, J.H.: Nucleotide sequence of yellow fever virus: Implications for flavivirus gene expression and evolution. Science 229:726-733 (1985). 
Roehrig, J.T.: The use of monoclonal antibodies in studies of the structural proteins of togaviruses and flaviviruses. In: Schlesinger, S.; Schlesinger, M.J. (eds.), The Togaviridae and Flaviviridae, pp. 251-278 (Plenum Press, New York, London, 1985).

Ruiz-Linares, A.; Cahour, A.; Despres, P.; Girard, M.; Bouloy, M.: Processing of yellow fever virus polyprotein: Role of cellular proteases in maturation of the structural proteins. J. Virol. 63: 4199-4209 (1989).

Schlesinger, S.; Schlesinger, M.J.: The Togaviridae and Flaviviridae. (Plenum Press, New York, 1986).

Shapiro, D.; Brandt, W.E.; Russell, P.K.: Change involving a viral membrane glycoprotein during morphogenesis of group B arboviruses. Virology 50: 906-911 (1972).

Speight, G.; Coia, G.; Parker, M.D.; Westaway, E.G.: Gene mapping and positive identification of the non-structural proteins NS2A, NS2B, NS3, NS4B and NS5 of the flavivirus Kunjin and their cleavage sites. J. gen. Virol. 69: 23-34 (1988).

Trousdale, M.D.; Trent, D.W.; Shelokov, A.: Simian hemorrhagic fever virus: a new togavirus. Proc. Soc. Exp. Biol. Med. 150:707-711 (1975).

Westaway, E.G.: Flavivirus replication strategy. Adv. Virus Res. 33:45-90 (1987).

Westaway, E.G.; Brinton, M.A.; Gaidamovich, S.Ya.; Horzinek, M.C.; Igarashi, A.; Kaariainen, L.; Lvov, D.K.; Porterfield, J.S.; Russell, P.K.; Trent, D.W.: Flaviviridae. Intervirology 24:183-192 (1985). 


\begin{tabular}{|lll}
\hline FAMILY CORONAVIRUS GROUP & CORONAVIRIDAE \\
\hline
\end{tabular}

Reported by D. Cavanagh

\begin{tabular}{llc}
\hline \hline GENUS & \multicolumn{1}{c}{-} & CORONAVIRUS \\
\hline TYPE SPECIES & AVIAN INFECTIOUS & - \\
& BRONCHITIS VIRUS (IBV) & \\
\hline
\end{tabular}

\section{Properties of the Virus Particle}

Morphology

Spherical or pleomorphic enveloped particles, 60 to 220 $\mathrm{nm}$ in diameter. Club-shaped surface projections, 12-24 $\mathrm{nm}$ in length protruding from envelope. Internal RNP structure seen by negative staining as helix of $9-13 \mathrm{~nm}$ or strands of $9 \mathrm{~nm}$ in diameter.

Physicochemical Buoyant density $=1.15-1.18 \mathrm{~g} / \mathrm{cm}^{3}$ in sucrose. Disrupted properties by ether, chloroform and detergents. Spike but not haemagglutinin-esterase protein of $\mathrm{BCV}$ removed by bromelain.

Nucleic acid

One molecule of infectious ssRNA; MW $=9.0-11.0 \times 10^{6}$ (IBV genome is $27.6 \mathrm{~kb}$; murine hepatitis virus $\approx 33 \mathrm{~kb}$ ). Polyadenylated at 3'-terminus. MHV genomic RNA known to be capped.

Protein

\section{Lipid}

Carbohydrate
3 or 4 proteins. All coronaviruses have spike (S), membrane (M) and nucleocapsid $(\mathrm{N})$ proteins and some have haemagglutinin-esterase (HE) protein. HE protein has homology with subunit 1 of haemagglutinin-esterasefusion protein of influenza $\mathrm{C}$ virus; but nature of gene acquisition uncertain (recombination?). S (MW $=170-220$ $\mathrm{x} 10^{3}$ ) may be cleaved or uncleaved (two subunits: Nterminal S1, C-terminal S2). $M$ present in several differentially glycosylated forms ( $\mathrm{MW}$ of main species = $\left.23-29 \times 10^{3}\right)$. Nucleocapsid $\left(\mathrm{MW}=47-60 \times 10^{3}\right)$ phosphorylated and associated with RNA. Membrane fusion and esterase activity associated with $\mathrm{S}$ and $\mathrm{HE}$ proteins, respectively.

Present. S protein acylated.

Present. Spike and haemagglutinin-esterase proteins Nglycosylated. Membrane protein N-glycosylated in IBV, porcine transmissible gastroenteritis and turkey coronaviruses but $\mathrm{O}$-glycosylated in murine hepatitis and bovine coronavirus. 
Antigenic properties

Host range

Transmission
3 or 4 major antigens corresponding to each virion protein. Spike and haemagglutinin-esterase predominant antigens involved in neutralization.

\section{REPLICATION}

Genomic RNA assumed to be mRNA for RNA polymerase responsible for amplification of genome and production of subgenomic mRNAs. One species of negative-stranded RNA is of genome-length that acts as template for the synthesis of a 3'-coterminal set of subgenomic mRNAs which are capped and polyadenylated. Synthesis of mRNA from this template involves a process of discontinuous transcription, probably by a leader-priming mechanism. Apparently, mRNAs serve as templates for their own replication since negative stranded RNAs of mRNA length are also found as part of subgenomic RIs. Another possibility is that the negative stranded subgenomic RNAs may arise by discontinuous transcription on the genome template. Translation of polymerase gene involves ribosomal frame shifting (IBV and murine hepatitis virus). There is a high frequency of recombination (murine hepatitis virus). Number of major subgenomic mRNAs varies from 5-7 depending on virus. The mRNAs encoding structural proteins have been identified for several coronaviruses. Only the 5'-unique regions i.e. those absent from the next smaller RNA, are thought to be translationally active. Structural genes clustered at 3'-end of genome. Virions mature in the cytoplasm by budding through endoplasmic reticulum and golgi membranes. No budding at plasmalemma.

\section{Biological ASpects}

Infections generally restricted to natural vertebrate host. Often associated with respiratory or gastrointestinal organs.

Biological vectors not known. Respiratory and faecal-oral transmission. Mechanical transmission common.

\section{OTHER MEMBERS}

Human coronavirus Murine hepatitis virus

Porcine hemagglutinating encephalomyelitis virus

Porcine transmissible gastroenteritis virus

Bovine coronavirus

Canine coronavirus

Feline infectious peritonitis virus 
Turkey coronavirus

\title{
Probable members
}

\author{
Rat coronavirus \\ Porcine epidemic diarrhea virus
}

\section{Possible member}

Rabbit coronavirus

\section{Derivation of Name \\ corona: from Latin 'crown', from appearance of surface projections in negatively stained electron micrographs.}

\section{REFERENCES}

Banner, L.R.; Keck, J.G.; Lai, M.M.C.: A clustering of RNA recombination sites adjacent to a hypervariable region of the peplomer gene of murine coronavirus. Virology 175: 548555 (1990).

Boursnell, M.E.G.; Brown, T.D.K.; Foulds, I.J.; Green, P.F.; Tomley, F.M.; Binns, M.M.: Completion of the sequence of the genome of the coronavirus avian infectious bronchitis virus. J. gen. Virol. 68:57-77 (1987).

Brierley, I.; Digard, P.; Inglis, S.C.: Characterization of an efficient coronavirus ribosomal frameshifting signal: requirement for an RNA pseudoknot. Cell 57: 537-547 (1989).

Cavanagh, D.; Brian, D.A.; Enjuanes, L.; Holmes, K.V.; Lai, M.M.C.; Laude, H.; Siddell, S.G.; Spaan, W.J.M.; Taguchi, F.; Talbot, P.J.: Recommendations of the Coronavirus Study Group for the nomenclature of the structural proteins, mRNAs and genes of coronaviruses. Virology 176: 306-307 (1990).

Cavanagh, D.; Brown, T.D.K.: Coronaviruses and Their Diseases. (Plenum Press, New York, 1990).

Luytjes, W.; Bredenbeek, P.J.; Noten, A.F.H.; Horzinek, M.C.; Spaan, W.J.M.: Sequence of mouse hepatitis virus A59 mRNA2: indications for RNA recombination between coronaviruses and influenza $C$ virus. Virology 166: 415-422 (1988).

Pachuk, C.J.; Bredenbeek, P.J.; Zoltick, P.W.; Spaan, W.J.M.; Weiss, S.R.: Molecular cloning of the gene encoding the putative polymerase of mouse hepatitis coronavirus, strain A59. Virology 171: 141-148 (1989).

Rasschaert, D.; Gelfi, J.; Laude, H.: Enteric coronavirus TGEV: partial sequence of the genomic RNA, its organization and expression. Biochimie 69: 591-600 (1987).

Sawicki, S.G.; Sawicki, D.L.: Coronavirus transcription: subgenomic mouse hepatitis virus replicative intermediates function in RNA synthesis. J. Virol. 64: 1050-1056 (1990).

Sethna, P.B.; Hung, S.L.; Brian, D.A.: Coronavirus subgenomic minus-strand RNAs and the potential for mRNA replicons. Proc. Natl. Acad. Sci. USA 86: 5626-5630 (1989).

Spaan, W.J.M.; Cavanagh, D.; Horzinek, M.C.: Coronaviruses. In van Regenmortel, M.H.V.; Neurath, A.R. (eds.), Immunochemistry of Viruses, Vol. II, pp. 359-379 (Elsevier/North Holland, Amsterdam, 1990).

Spaan, W.J.M.; Cavanagh, D.; Horzinek, M.C.: Coronaviruses: structure and genome expression. J. gen. Virol. 69: 2939-2952 (1988).

Vlasak, R.; Luytjes, W.; Leider, J.; Spaan, W.; Palese, P.: The E3 protein of bovine coronavirus is a receptor-destroying enzyme with acetylesterase activity. J. Virol. 62 : 4686-4690 (1988). 


\begin{tabular}{lcc}
\hline \hline GENUS & - & TOROVIRUS \\
\hline TYPES SPECIES & BERNE VIRUS & - \\
\hline
\end{tabular}

Compiled by M.C. Horzinek

Morphology Pleomorphic, bioconcave disk-, kidney- and rod-shaped particles $120-140 \mathrm{~nm}$ in diameter containing an elongated tubular capsid with helical symmetry. Peplomer-bearing envelope.

Physicochemical $S_{20 \mathrm{w}}=380-400$; buoyant density in sucrose $1.16-1.17$ properties

$\mathrm{g} / \mathrm{cm}^{3}$; stable between $\mathrm{pH} 2.5$ and 9.7 .

Nucleic acid Polyadenylated linear positive-sense ssRNA (infectious) > $20 \mathrm{~kb}$.

Protein Three major proteins in virus particle with $\mathrm{MW} \approx 18 \times 10^{3}$ (nucleocapsid), $26 \times 10^{3}$ (envelope) and 80-100 × $10^{3}$ (peplomer dimer derived from $200 \times 10^{3}$ precursor).

\section{Lipid}

Carbohydrate

Host range

Transmission

Present.

Only peplomer protein is glycosylated.

\section{REPLICATION}

In cytoplasm, 3'-coterminal nested set of 5 subgenomic mRNAs is detected. The polymerase gene contains two overlapping ORFs; the more downstream one is expressed by ribosomal frame-shifting during translation of genomic RNA. Budding of preformed tubular capsids through Golgi membranes and endoplasmic reticulum; host cell nuclear function required.

\section{Biological ASpects}

Ungulates, man; probably also carnivores (mustellids).

Probably via the faecal-oral route.

\section{OTHER MEMBERS}

Breda virus (cattle).

\begin{tabular}{ll}
\hline \hline $\begin{array}{l}\text { Derivation of } \\
\text { Name }\end{array}$ & $\begin{array}{l}\text { toro: from Latin torus, 'lowest convex molding in the base } \\
\text { of a column'. }\end{array}$ \\
\hline \hline
\end{tabular}




\section{REFERENCES}

Horzinek, M.C.; Flewett, T.H.; Saif, L.J.; Spaan, W.J.M.; Weiss, M.; Woode, G.N.: A new family of vertebrate viruses: Toroviridae. Intervirology 27: 17-24 (1987).

Snijder, E.J.; Ederveen, J.; Spaan, W.J.M.; Weiss, M.; Horzinek, M.C.: Characterization of Berne virus genomic and messenger RNAs. J. gen. Virol. 69: 2135-2144 (1988).

Snijder, E.J.; Horzinek, M.C.; Spaan, W.J.M.: A 3'-coterminal nested set of independently transcribed messenger RNAs is generated during Berne virus replication. J. Virol. 64: 331-338 (1990).

Weiss, M.; Steck, F.; Horzinek, M.C.: Purification and partial characterization of a new enveloped RNA virus (Berne virus). J. gen. Virol. 64: 1849-1858 (1983).

Weiss, M.; Horzinek, M.C.: Morphogenesis of Berne virus (proposed family Toroviridae). J. gen. Virol. 67: 1305-1314 (1986). 


\begin{tabular}{|lll|}
\hline ORDER & - & MONONEGAVIRALES \\
\hline
\end{tabular}

Compiled by C.R. Pringle

\section{Morphology}

\section{Physicochemical properties}

Nucleic acid

\section{GeneraL}

The order embraces the three families of eukaryotic viruses possessing linear non-segmented negative-strand RNA genomes, i.e. the Filoviridae, Paramyxoviridae and Rhabdoviridae. Common features include the negativesense template RNA in the virion, the helical nucleocapsid, the initiation of primary transcription by a virion-associated RNA dependent RNA polymerase, similar gene order (3' NTR - core protein genes - envelope protein genes polymerase gene - 5' NTR) and single $3^{\prime}$ promoter. Maturation is by budding, predominantly from the plasma membrane; rarely from internal membranes (rabies virus) or the inner nuclear membrane (many plant rhabdoviruses). Cytoplasmic, except for some plant rhabdoviruses.

\section{Properties of The Virus Particle}

The virions are large enveloped structures with a prominent fringe of spikes, 5-10 nm long and spaced 7-10 $\mathrm{nm}$ apart. The morphologies of the particles are variable but distinguish the three families: Simple, branched, Ushaped, 6-shaped, or circular filaments of uniform diameter $(\approx 80 \mathrm{~nm})$ extending up to $14,000 \mathrm{~nm}$ are characteristic of the Filoviridae, although purified virions are bacilliform and of uniform length (e.g. $790 \mathrm{~nm}$ in the case of Marburg virus); filamentous, pleomorphic or spherical structures of variable diameter are characteristic of the Paramyxoviridae; and regular bullet-shaped or bacilliform particles are characteristic of the Rhabdoviridae. The helical ribonucleoprotein core has a diameter of 13-20 nm which in filoviruses and rhabdoviruses is organised into a helical nucleocapsid of $\approx 50 \mathrm{~nm}$ diameter. The nucleocapsid of VSV is infectious.

$\mathrm{MW}=300-1000 \times 10^{6} . \mathrm{S}_{20 \mathrm{w}}=550->1000$. Buoyant density in sucrose $=1.18-1.20 \mathrm{~g} / \mathrm{cm}^{3}$.

One molecule of linear non-infectious negative-sense single-stranded RNA, MW $=3.5-7 \times 10^{6} .0 .5-2.0 \%$ of particle by weight. Genome comprises a linear sequence of non-overlapping genes with short terminal untranscribed regions and intergenic regions ranging from 
2 to several hundred nucleotides; the only known exceptions are a short overlap of the 9th and 10th genes of respiratory syncytial virus, and encoding of genetic information in all three reading frames in the $\mathrm{P}$ genes of paramyxoviruses and morbilliviruses. Genome sizes so far determined range from $11.161 \mathrm{~kb}$ (VSV) to $15.892 \mathrm{~kb}$ (measles virus). Infectivity sensitive to lipid solvents.

Protein

Lipid

Carbohydrate

Antigenic

properties

Pathogenic potential
Limited in number in relation to the large particle size; probably no more than 5-7 structural proteins comprising envelope glycoprotein(s), a matrix protein, a major RNAbinding protein, nucleocapsid-associated protein(s) and a large molecular weight polymerase protein, plus in paramyxoviruses several non-structural proteins of unknown function. Enzymes associated with virions may include transcriptase, polyadenylate transferase, mRNA methyl transferase, neuraminidase.

\section{$15-25 \%$ by weight, composition dependent on host cell.}

3-6\%, where known.

Membrane glycoproteins involved in neutralisation; serotypes defined by surface antigens. Filoviruses exceptional in that cannot be neutralised in vitro.

Variable, but in human hosts tends to be characteristic of family: Haemorrhagic fever (Filoviridae); respiratory and neurological disease (Paramyxoviridae); mild febrile to fatal neurological disease (Rhabdoviridae).

\section{REPLICATION}

Discrete unprocessed messenger RNAs are transcribed by sequential interrupted synthesis. Generally genes do not overlap and only 1 ORF utilised; the $\mathrm{P}$ genes of paramyxoviruses and morbilliviruses are exceptional in that all 3 ORFs may be utilised; alternate starts, non-AUG starts, and mRNA editing by insertion of non-templated nucleotides to change reading frame are devices uniquely employed in the expression of $\mathrm{P}$ gene products. Replication occurs by synthesis of a complete positivesense RNA anti-genome. Maturation of the independently assembled helical nucleocapsids occurs by budding through host membranes and investment by a host-derived lipid envelope containing transmembrane virus proteins. 


\section{Biological Aspects}

Host range Ranging from restricted to unrestricted. Filoviruses have only been isolated from primates. Paramyxoviruses occur only in vertebrates and no vectors are known. Rhabdoviruses infect invertebrates, vertebrates and plants: Some rhabdoviruses multiply in both invertebrates and vertebrates, some in invertebrates and plants, but none in all three hosts.

FAMilies, Sub-FAMILIES AND GENERA

Family Sub-family Genus

Filoviridae

Filovirus

Paramyxoviridae

Paramyxovirinae

Pneumovirinae

Rhabdoviridae
Morbillivirus

Paramyxovirus

Pneumovirus

Lyssavirus

Vesiculovirus

\section{Derivation of} Name

mono from Greek monos 'single'; nega from negative strand RNA; virales from Latin virales 'viruses'.

\section{REFERENCES}

Kiley, M.P.; Bowen, E.T.A.; Eddy, G.A.; Isaacson, M.; Johnson, K.M.; McCormick, J.B.; Murphy, F.A.; Pattyn, S.R.; Peters, D.; Prozesky, O.W.; Regnery, R.L.; Simpson, D.I.H.; Slenczka, W.; Sureau, P.; van der Groen, G.; Webb , P.A.; Wulff, H.: Filoviridae, a Taxonomic Home for Marburg and Ebola Viruses: Intervirology 18: 2432 (1982).

Kingsbury, D.W.: The Paramyxoviruses. (Plenum Press, New York, 1991).

Pringle, C.R.: The order Mononegavirales. Arch. Virol. 117:137-140 (1991).

Wagner, R.R.: The Rhabdoviruses. (Plenum Press, New York, 1987). 
Morphology

Physicochemical properties

Nucleic acid

Protein
Reported by C.R. Pringle

\section{Properties of The Virus Particle}

Pleomorphic, usually roughly spherical, $150 \mathrm{~nm}$ or more in diameter, but filamentous forms common; envelope derived from cell membrane lipids, incorporating 2 or 3 virus glycoproteins and 1 or 2 unglycosylated proteins. Surface projections $8-12 \mathrm{~nm}$ in length, spaced 7-10 nm apart according to genus, contain virus glycoproteins. Nucleocapsid has helical symmetry, $13-18 \mathrm{~nm}$ in diameter and $5.5-7 \mathrm{~nm}$ pitch according to genus; length up to $1 \mu \mathrm{m}$ in some genera.

MW $>500 \times 10^{6}$, much more for pleomorphic multiploid virions; $S_{20 \mathrm{w}}$ at least 1000 ; buoyant density in sucrose $=$ $1.18-1.20 \mathrm{~g} / \mathrm{cm}^{3}$; sensitive to lipid solvents, non-ionic detergents, formaldehyde, and oxidising agents.

Single molecule of ssRNA, MW $=5-7 \times 10^{6}$. About $0.5 \%$ by weight of virus particle. Genomic size fairly uniform: $15.156 \mathrm{~kb}$ for Newcastle disease virus, 15.222 $\mathrm{kb}$ for human respiratory syncytial virus, $15.285 \mathrm{~kb}$ for Sendai virus, $15.463 \mathrm{~kb}$ for parainfluenza virus type 3 and $15.892 \mathrm{~kb}$ for measles virus. Most particles contain a negative-sense strand, but some contain positive-sense template strands. Thus partial self-annealing of isolated RNA may occur.

Paramyxoviruses and morbilliviruses have 7-8 ORFs (genes) that encode $10-12$ proteins $\left(\mathrm{MW} \approx 5-200 \times 10^{3}\right.$ ), of which 4-5 are derived from 2-3 overlapping ORFs of the P locus. Pneumoviruses have 10 ORFs encoding 10 proteins of MW $=7.5-200 \times 10^{3}$, the 9th and the 10th ORFs overlapping in respiratory syncytial virus. Proteins common to all genera are: three nucleocapsid-associated proteins, namely an RNA-binding protein (N or NP), a phosphoprotein $(\mathrm{P})$, a large putative polymerase protein (L); an unglycosylated envelope protein (M); and two glycosylated envelope proteins, comprising a fusion protein $(\mathrm{F})$ and an attachment protein ( $\mathrm{G}, \mathrm{H}$ or $\mathrm{HN})$. Variable proteins include the nonstructural proteins (C, $1 \mathrm{C} / \mathrm{NS} 1$, and $1 \mathrm{~B} / \mathrm{NS} 2)$, a small integral membrane protein (SH/1 A), a second inner envelope unglycosylated protein $(\mathrm{M} 2 / 22 \mathrm{kDa})$, and a cysteine-rich protein $(\mathrm{V})$. Enzymes (variously represented and reported among genera); 
Lipid

Carbohydrate

Antigenic properties

Effect on cells transcriptase, polyadenylate transferase, mRNA methyl transferase, neuraminidase.

$20-25 \%$ by weight, host cell derived.

$6 \%$ by weight, composition dependent on host cell.

One or more surface antigens involved in virus neutralisation; one nucleocapsid antigen described; specificities of antigens vary among genera.

Generally cytolytic, but temperate and persistent infections are common; other features are inclusions, syncytium formation, and haemadsorption.

\section{REPLICATION}

Virus entry by fusion of envelope with cell surface membrane at neutral $\mathrm{pH}$; genome transcribed from single promoter into 6-10 separate mRNAs, nucleocapsid is the functional template for transcription of complementary viral mRNA species and for RNA replication. Independently assembled nucleocapsids are enveloped on cell surface at sites containing virus envelope proteins. Paramyxoviruses and morbilliviruses exhibit a novel strategy whereby the variable inclusion of non-templated nucleotides at one site in mRNA from the $\mathrm{P}$ locus results in a shift in reading frame and expression of the $\mathrm{V}$ protein (and in some of the D protein). C protein(s) are expressed from alternate and non-AUG starts by independent ribosomal initiation. Virions are released by budding. Variable dependence on host nuclear functions.

\section{Biological Aspects}

Host range Only found in vertebrates. Each virus has its own host range in nature and in the laboratory.

Transmission Horizontal, mainly airborne; no vectors.
PARAMYXOVIRINAE

\section{GENERA}

Parainfluenza virus group

Measles-rinderpestdistemper virus group
Paramyxovirus

Morbillivirus 


\begin{tabular}{lll}
\hline \hline GENUS & PARAINFLUENZA & PARAMYXOVIRUS \\
& VIRUS GROUP & - \\
\hline TYPE SPECIES & NEWCASTLE DISEASE VIRUS & \\
& AVIAN PARAMYXOVIRUS & \\
& TYPE 1 (PMV-1) \\
\hline
\end{tabular}

\section{Properties of the Virus Particle}

All members of the genus possess a neuraminidase, in contrast to members of the other two genera.

\section{OTHER MEMBERS}

Avian paramyxovirus 2 (Yucaipa) (PMV-2)

Avian paramyxovirus 3

Avian paramyxovirus 4

Avian paramyxovirus 5 (Kunitachi)

Avian paramyxovirus 6

Avian paramyxovirus 7

Avian paramyxovirus 8

Avian paramyxovirus 9

(PMV-9)

Parainfluenza virus type 1 human, murine (Sendai)

Parainfluenza virus type 3 human, bovine, ovine,

Parainfluenza virus type $2 \quad$ simian (SA10)

Parainfluenza virus type 4

simian (SV5, SV41)

human

Mumps virus

human

\begin{tabular}{llc}
\hline \hline GENUS & MEASLES-RINDERPEST- & MORBILLIVIRUS \\
& DISTEMPER VIRUS GROUP & \\
\hline TYPE SPECIES & MEASLES VIRUS & - \\
\hline
\end{tabular}

Properties of the Virus Particle

All members lack the neuraminidase possessed by the genus Paramyxovirus, and differ from the genus Pneumovirus in size of the nucleocapsid and other features. All members produce both cytoplasmic and intranuclear inclusion bodies which contain viral RNP. Members of this genus are related antigenically.

\section{OTher Members}

Canine distemper virus

Phocine distemper virus

canine, mustelid phocine-phocid, phocoenine 
$\underline{\text { Taxonomic status }}$

English vernacular name

International name

Peste-des-petits-ruminants virus

Rinderpest virus

caprine,ovine bovine,caprine, ovine,porcine

\begin{tabular}{lll}
\hline \hline SUBFAMILY & \multicolumn{1}{c}{ PNEUMOVIRINAE } \\
\hline & GENERA & \\
& Respiratory syncytial virus group & Pneumovirus \\
\hline \hline GENUS & $\begin{array}{l}\text { RESPIRATORY SYNCYTIAL } \\
\text { VIRUS GROUP }\end{array}$ & PNEUMOVIRUS \\
\hline TYPE SPECIES & $\begin{array}{l}\text { HUMAN RESPIRATORY } \\
\text { SYNCYTIAL VIRUS }\end{array}$ & - \\
\hline
\end{tabular}

\section{Properties of the Virus Particle}

Lacks neuraminidase; haemagglutinin absent in bovine and human respiratory syncytial viruses, present in pneumonia virus of mice. Differs from the other two genera in several features: gene number (10 compared with $7 / 8$ transcriptional units), smaller average gene size, possession of one additional unglycosylated membraneassociated protein (M2/22 kDa), inversion of attachment $(\mathrm{G})$ and fusion $(\mathrm{F})$ proteins in the gene order, extensive $\mathrm{O}$ linked glycosylation of the $G$ protein, $P$ locus encodes a single protein. Nucleocapsid diameter (13-14 $\mathrm{nm}$ compared with $18 \mathrm{~nm})$, nucleocapsid pitch $(7 \mathrm{~nm}$ compared with $5.5 \mathrm{~nm})$, length of spike (10-12 nm compared with $8 \mathrm{~nm}$ ).

\section{OTHER MEMBERS}

Bovine respiratory syncytial virus bovine,caprine,ovine Pneumonia virus of mice Turkey rhinotracheitis virus rodent avian

\section{Uncharacterised paramyxoviruses}

Fer-de-Lance virus

La-Piedad-Michoacan-Mexico virus (LPMV)

Mapuera virus

Nariva virus

Several viruses from penguins distinct from PMV1-9 reptillian porcine chiropteran rodent avian 
Derivation of

paramyxo: from Greek para, 'by the side of', and myxa

Name 'mucus' (relating to activity of haemagglutinin and neuraminidase).

morbilli: plural of Latin morbillus, diminutive of morbus, 'disease'; measles from Germanic Masemn.

pneumo: from Greek pneuma, 'breath'.

\section{REFERENCES}

Alexander, D.J.: The classification, host range and distribution of avian paramyxoviruses, In McFerran, J.B.; McNulty, M.S. (eds.): Acute Virus Infections in Poultry, pp. 52-66 (Martinus Nijhoff, Dordrecht, 1986).

Bishop, D.H.L.; Compans, R.W.: Nonsegmented negative strand viruses; Paramyxoviruses and Rhabdoviruses (Academic Press, Orlando, 1984).

Choppin, P.W.; Compans, R.W.: Reproduction of paramyxoviruses. In Fraenkel-Conrat, H.; Wagner, R.R. (eds.), Comprehensive Virology, Vol. 4, pp. 95-178 (Plenum Press, New York, 1975).

Kingsbury, D.W.: The Paramyxoviruses (Plenum Press, New York, 1991).

Kingsbury, D.W.: Paramyxoviridae and their replication. In Fields, B.N.; Knight, J.C. (eds.), Virology, Vol. 1, 2nd edn., pp. 945-962 (Raven Press, New York, 1990).

Mahy, B.; Kolakofsky, D.: The Biology of negative strand viruses (Elsevier/North Holland, Amsterdam, Oxford, New York, 1987).

Morrison, T.G.: Structure, function and intracellular processing of paramyxovirus membrane proteins. Virus Res. 10: 113-136 (1988).

Orvell, C.; Norrby, E.: Antigenic structure of paramyxoviruses. In van Regenmortel, M.H.V.; Neurath, A.R. (eds.), Immunochemistry of Viruses. The Basis for Serodiagnosis and Vaccines, pp. 241-264 (Elsevier Medical Press, Amsterdam, 1985).

Pringle, C.R.: Paramyxoviruses and Disease. In Russell, W.C.; Almond, J.W. (eds.), SGM Symposium 40, Molecular basis of virus disease, pp. 51-90 (Cambridge University Press, Cambridge, 1987).

Stott, E.J.; Taylor, G.: Respiratory syncytial virus; brief review. Arch. Virol. 84: 1-52 (1984). 


FAMILY MARBURG VIRUS GROUP FILOVIRIDAE

Compiled by J.B. McCormick

\begin{tabular}{lcc}
\hline \hline GENUS & - & FILOVIRUS \\
\hline TYPE SPECIES & MARBURG VIRUS & - \\
\hline
\end{tabular}

Properties of The Virus Particle

Morphology Pleomorphic, virions appearing as long filamentous forms (sometimes with extensive branching) or as U-shaped, "6"-shaped or circular forms. Particles vary greatly in length (up to $14,000 \mathrm{~nm}$ ), but of uniform diameter $\approx 80$ $\mathrm{nm}$. There are surface projections $\approx 7 \mathrm{~nm}$ in length spaced at $10 \mathrm{~nm}$ intervals on the particle surface. Virions purified by rate zonal gradient centrifugation are infectious, uniform and bacilliform in shape; Ebola $970 \mathrm{~nm}$ and Marbourg $790 \mathrm{~nm}$ long. Inside the envelope is a nucleocapsid with a dark central axis $\approx 20 \mathrm{~nm}$ in diameter surrounded by a helical tubular capsid $\approx 50 \mathrm{~nm}$ in diameter bearing cross-striations with a periodicity $\approx 5 \mathrm{~nm}$. The 20 $\mathrm{nm}$ central axis, also seen in infected cells appears to be the virion RNP. A structure with buoyant density $\approx 1.32$ $\mathrm{g} / \mathrm{cm}^{3}$ in $\mathrm{CsCl}$, is released from virions by detergent treatment and probably represents the viral RNP. Within the nucleocapsid is an axial channel $\approx 10-15 \mathrm{~nm}$ with nucleocapsid proteins (N and VP30); proteins L and VP35, the putative transcriptase are associated with the RNP.

Physicochemical $\mathrm{MW}=300-600 \times 10^{6} ; \mathrm{S}_{20 \mathrm{w}}$.of long particles very high properties but infectious bacilliform particles $\approx 1,400 \mathrm{~S}$; buoyant density $\approx 1.14 \mathrm{~g} / \mathrm{cm}^{3}$ in potassium tartrate. Infectivity is quite stable at room temperature but is destroyed in 30 min at $60^{\circ} \mathrm{C}$. Sensitive to lipid solvents.

Nucleic acid One molecule of noninfectious (negative strand) linear ss $\mathrm{RNA} ; \mathrm{MW} \approx 4.5 \times 10^{6} \approx 1.1 \%$ by weight of virus.

Protein 7 proteins designated L, G, N, VP40, VP35, VP30 and VP24. G is very large and 2 are associated with RNA (N and VP30).

Lipid

Present.

Carbohydrate Associated with surface projections and possibly glycolipid. 
Antigenic properties

Host range

Transmission
Virus cannot be neutralized in vitro. There is no antigenic cross-reaction between Marburg and Ebola. The two Ebola biotypes, Zaire and Sudan, can be differentiated antigenically. $G$ protein seems to define serotype.

\section{REPLICATION}

Seven virion proteins are translated from monocistronic mRNA complementary to virion RNA. Virion transcriptase activity has been detected. Synthesized proteins accumulate in the cytoplasm. Budding of virions appears to be through plasma membrane. Little virion RNA accumulates in infected cells suggesting a very efficient maturation process. Viruses share similar replication signals with both rhabdoviruses and paramyxoviruses.

\section{Biological Aspects}

Both viruses are indigenous to Africa. Ebola strains have also come from South-east Asia. Some strains cause severe hemorrhagic fevers in humans. Marburg was first isolated from hemorrhagic fever patients in West Germany and Yugoslavia in 1967 by contact with tissues and blood from infected but apparently healthy monkeys (Ceriopithecus aethiops) imported from Uganda. Ebola virus was first isolated from two separate outbreaks in northern Zaire and southern Sudan in the fall of 1976.

The natural reservoir or source of either virus is unknown. In the laboratory, monkey, mouse, guinea pig and hamster have been experimentally infected.

In human cases, transmission appears to occur only by close personal contact. Mortality in outbreaks may be as high as $88 \%$.

\section{OTHER MEMBER}

Ebola virus (Zaire and Sudan biotypes).
Derivation of Name filo: from Latin filo 'thread-like', for the morphology of the particles. 


\section{REFERENCES}

Buchmeier, M.J.; DeFries, R.U.; McCormick, J.B.; Kiley, M.P.: Comparative analysis of the structural polypeptides of Ebola viruses from Sudan and Zaire. J. Infect. Dis. 147:276281 (1983).

Cox, N.J.; McCormick, J.B.; Johnson, K.M.; Kiley, M.P.: Evidence for two subtypes of Ebola virus based on oligonucleotide mapping of RNA. J. Infect. Dis. 147:272-275 (1983).

Elliott, L.H.; Kiley, M.P.; McCormick, J.B.: Descriptive analysis of Ebola virus proteins. Virology 147:169-176 (1985).

Kiley, M.P.; Bowen, E.T.A.; Eddy, G.A.; Isaacson, M.; Johnson, K.M.; McCormick, J.B.; Murphy, F.A.; Pattyn, S.R.; Peters, D.; Prozesky, O.W.; Regnery, R.L.; Simpson, D.I.H.; Slenczka, W.; Sureau, P.; van der Groen, G.; Webb, P.A.; Wulff, H.: Filoviridae: a Taxonomic Home for Marburg and Ebola viruses? Intervirology 18:24-32 (1982).

Kiley, M.P.; Wilusz, J.; McCormick, J.B.; Keene, J.D.: Conservation of the 3' terminal nucleotide sequences of Ebola and Marburg virus. Virology 149:251-254 (1986).

Martini, G.; Siegert, R.: Marburg Virus Disease. (Springer, New York, 1971).

Pattyn, S.R.: Ebola virus haemorrhagic fever. (Elsevier/North Holland, Amsterdam, 1978).

Regnery, R.L.; Johnson, K.M.; Kiley, M.P.: Virion nucleic acid of Ebola virus. J. Virol. 36:465-469 (1980).

Regnery, R.L.; Johnson, K.M.; Kiley, M.P.: Marburg and Ebola viruses: possible members of a new group of negative strand viruses. In Bishop, D.H.L.; Compans, R.W. (eds.), The replication of negative strand viruses. pp. 971-977 (Elsevier/North Holland, New York, 1981).

Richman, D.D.; Cleveland, P.H.; McCormick, J.B.; Johnson, K.M.: Antigenic analysis of strains of Ebola virus: identification of two Ebola virus serotypes. J. Infect. Dis. 147:268-271 (1983).

Sanchez, A.; Kiley, M.P.: Identification and analysis of Ebola virus messenger RNA. Virology 157:414-420 (1987). 


\begin{tabular}{|lll|}
\hline FAMILY & $\begin{array}{l}\text { BULLET-SHAPED } \\
\text { VIRUS GROUP }\end{array}$ & $R H A B D O V I R I D A E$ \\
\hline
\end{tabular}

Morphology

Physicochemical properties

Nucleic acid

Protein

Lipid

Carbohydrate
Revised by W.H. Wunner \& D. Peters

\section{Properties of the Virus Particle}

Viruses infecting vertebrates and invertebrates are usually bullet-shaped, and those infecting plants are usually bacilliform; $100-430 \mathrm{~nm}$ long and 45-100 $\mathrm{nm}$ in diameter, with surface projections (G protein) $5-10 \mathrm{~nm}$ long and $\approx 3$ $\mathrm{nm}$ in diameter. In thin section, a central axial channel is seen. Characteristic cross-striations (spacing 4.5-5.0 nm) are seen in negatively stained and thin-sectioned particles. Truncated particles 0.1-0.5 of the length of the virus may be common except perhaps in members infecting plants. Abnormally long and double-length particles and tandem formations are sometimes observed. A honeycomb pattern is observed on the surface of some members. The inner nucleocapsid, $\approx 50 \mathrm{~nm}$ in diameter, with helical symmetry, consists of an $\mathrm{RNA}+\mathrm{N}$ protein complex together with $\mathrm{L}$ and NS proteins, surrounded by an envelope containing $M$ protein. The nucleocapsid contains transcriptase activity and is infectious. It uncoils to a helical structure $\approx 20 \mathrm{x}$ $700 \mathrm{~nm}$.

$\mathrm{MW}=300-1,000 \times 10^{6} ; \mathrm{S}_{20 \mathrm{w}}=550-1,000 ;$ buoyant density in $\mathrm{CsCl}=1.19-1.20 \mathrm{~g} / \mathrm{cm}^{3}$ and in sucrose, 1.17 $1.19 \mathrm{~g} / \mathrm{cm}^{3}$. Infectivity; stable at the range $\mathrm{pH} 5-10$; rapidly inactivated at $56^{\circ} \mathrm{C}$ and by UV- and X-irradiation; sensitive to lipid solvents.

One molecule of noninfectious linear (negative-sense) ssRNA; $\mathrm{S}_{20 \mathrm{w}}=38-45 ; \mathrm{MW}=3.5-4.6 \times 10^{6} ; 1-2 \%$ by weight of virus.

Five major polypeptides [designated L, G,N,NS and M for vesicular stomatitis-Indiana (VS-I) virus]; $65-75 \%$ by weight of the virus. Other polypeptides may be present in minor amounts. Transcriptase and other enzyme activities are present in virus.

$15-25 \%$ by weight of virus, the composition being dependent on the host cell.

$3 \%$ by weight of virus. Associated with surface projections and glycolipids; minor variation with host cell type. 
Antigenic properties

Host range

Transmission
$\mathrm{G}$ protein is involved in virus neutralization and defines the serotype. $\mathrm{N}$ protein shows cross-reactions between some vesiculoviruses and between some lyssaviruses. N antigen is apparently different in two serotypes of potato yellow dwarf virus.

\section{REPLICATION}

Viral proteins accumulate in the cytoplasm except for some plant members. Virus RNA is transcribed by virion transcriptase into several positive-strand RNA species which act as mRNA in polyribosome complexes. Virus RNA replication involves ribonucleoprotein $(\mathrm{RNA}+\mathrm{N}$ protein, RNP) complex as nucleocapsid template to synthesize full-length positive-strand RNA intermediate. Viral nucleocapsid structures containing negative-strand $\mathrm{RNA}+\mathrm{N}, \mathrm{NS}$, and L proteins are formed in cytoplasm and virus is assembled from nucleocapsid $+\mathrm{M}$ protein complex with envelope produced independently by insertion of viral $\mathrm{G}$ protein into pre-existing host cell membranes. Site of formation of mature particles is variable, depending on virus and host cell - e.g. VS-I nucleocapsid is synthesized in cytoplasm and then virus predominantly buds from the plasma membrane in most, but not all, cells; rabies virus buds predominantly from intracytoplasmic membranes; and about half of the plant members bud from the inner nuclear membrane. Complete particles of these viruses accumulate in the perinuclear space.

\section{Biological ASPECTS}

Some members multiply in arthropods as well as vertebrates, others in arthropods and plants. Sigma virus was recognized first as a congenital infection of Drosophila. Some vertebrate members have a wide experimental host range. A wide range of vertebrate and invertebrate cells are susceptible to vertebrate viruses in vitro. Plant members usually have narrow host range among higher plants; some have been grown in insect cell cultures.

Some viruses are transmitted vertically in insects, but none is so transmitted in vertebrates or plants. Some can be transmitted mechanically in plants. Vector transmission by mosquitoes, sandflies, culicoides, mites, aphids, or leafhoppers. Mechanical transmission of viruses infecting vertebrates can be by contact or aerosol, bite or venereal. 


\section{GENERA/GROUPS}

Vesicular stomatitis virus group

Rabies virus group

Vesiculovirus

Plant rhabdovirus group

Lyssavirus

\begin{tabular}{lll}
\hline \hline GENUS & VESICULAR STOMATITIS & VESICULOVIRUS \\
& VIRUS GROUP & - \\
\hline TYPE SPECIES & VESICULAR STOMATITIS & \\
& -INDIANA VIRUS & \\
\hline
\end{tabular}

Properties of the Virus Particle

Morphology

Virus is $\approx 170 \mathrm{~nm}$ long, $\approx 70 \mathrm{~nm}$ wide. Helix of the nucleocapsid has an outer diameter of $\approx 49 \mathrm{~nm}$; inner diameter $\approx 29 \mathrm{~nm} ; 35$ subunits per turn. The RNP is linear and $\approx 1 \mu \mathrm{m}$ long.

Physicochemical $S_{20 w} \approx 625$. properties

Nucleic acid

Protein

\section{Antigenic properties}

The RNA genome of VS-I virus consists of 5 genes in tandem with no overlaps in the order $3^{\prime}-\mathrm{N}-\mathrm{NS}-\mathrm{M}-\mathrm{G}-\mathrm{L}-5^{\prime}$. All but 70 of the 11,161 nucleotides are represented in positive-strand transcripts comprising five monocistronic mRNAs plus an untranslated 3'-leader sequence of 47 nucleotides. The untranscribed regions are a 59 nucleotide 5 '-terminal region of the $\mathrm{L}$ gene, a 3 nucleotide spacer between leader and $\mathrm{N}$ gene, and 4 dinucleotide spacers (CA and GA) at the four inter-cistronic junctions. There is a common nucleotide sequence $3^{\prime}$-AUACUUUUUUU-5' preceding each intercistronic junction, and the sequences complementary to the 5'-end of each mRNA have the general form 3'-UUGUCNNUAG-5'.

$\mathrm{L}$ (large) $\mathrm{MW} \approx 150 \times 10^{3} ; \mathrm{G}$ (glycoprotein) $\mathrm{MW}=70-80$ $\mathrm{x} 10^{3} ; \mathrm{N}$ (nucleoprotein) $\mathrm{MW}=50-62 \times 10^{3} ; \mathrm{NS}$ (nonstructural and phosphorylated) $\mathrm{MW}=40-50 \times 10^{3} ; \mathrm{M}$ (matrix, phosphorylated) $\mathrm{MW}=20-30 \times 10^{3}$. Number of protein subunits in virion: $\mathrm{L}, 20-50 ; \mathrm{G}, 500-1,500 ; \mathrm{N}$, 1,000-2,000; NS, 100-300; M, 1,500-4,000. Enzymes in virion: transcriptase (made up of L + NS proteins); protein kinase (host?); guanyl and methyl transferases; nucleotide triphosphatase; nucleoside diphosphate kinase; $5^{\prime}$ capping enzyme.

$\mathrm{G}$ protein functions as type-specific immunizing antigen; $\mathrm{N}$ is cross-reacting $\mathrm{CF}$ antigen. 


\section{REPLICATION}

VS-I virus replicates in enucleate cells. Phenotypic mixing is extensive between VS-I and heterologous lytic viruses (simian virus 5, Newcastle disease virus, fowl plague virus, herpes simplex virus), nonlytic viruses (avian myeloblastosis virus, murine leukemia virus, mouse mammary tumor virus), and partially expressed endogenous viruses.Phenotypic mixing (complementation) also occurs within but not between serological types of vesiculoviruses. Complementation is reported to occur by re-utilization of structural components of UV-irradiated VS-I virus. Complementation shown with VS (Indiana, Cocal, New Jersey) and Chandipura. Five or six nonoverlapping groups (identified). Inter-strain complementation only observed with serologically related viruses - e.g. VS-I and Cocal.

\section{Biological ASPECTS}

VS-I serotype isolated from vertebrates and insects.

\section{OTHER MEMBERS}

Isolated in nature from vertebrates $(\mathrm{V})$ or invertebrates $(\mathrm{I})$ :

BeAn $157575(\mathrm{~V})$

Boteke (I)

Calchaqui (I)

Carajas (I)

Chandipura (I, V)

Cocal (I, V)

Eel virus American/Eel virus European (V)

Grasscarp rhabdovirus (V)

Gray Lodge (I)

Isfahan (I)

Jurona (I)

Klamath (V)

Kwatta

La Joya (I)

Malpais Spring (I)

Maraba (I)

Mount Elgon bat (V)

Perinet (I)

Pike fry rhabdovirus (V)

Piry (V)

Porton (I)

Radi (I) (= ISS Ph1 116)

Spring viremia of carp (V) (= Rhabdovirus carpia) 
Tupaia (V)

Ulcerative disease rhabdovirus (V)

Vesicular stomatitis Alagoas (V)

Vesicular stomatitis New Jersey (I, V)

Yug Bogdanovac (I)

\begin{tabular}{llc}
\hline \hline GENUS & RABIES VIRUS GROUP & LYSSAVIRUS \\
\hline TYPE SPECIES & RABIES VIRUS & - \\
\hline
\end{tabular}

\section{Properties of the Virus Particle}

Physiological properties

Nucleic acid

Protein

Antigenic properties
Morphologically and physicochemically similar to Vesiculovirus but antigenically distinct. Virus is $\approx 180$ $\mathrm{nm}(130-200 \mathrm{~nm})$ long, $\approx 75 \mathrm{~nm}(60-110 \mathrm{~nm})$ wide. Helical nucleocapsid has 30-35 subunits per turn. Unwound filamentous nucleocapsid $=4.2-4.6 \mu \mathrm{m}$. Surface projections $(\mathrm{G}$ protein $) \approx 10 \mathrm{~nm}$ long.

The RNA genome of rabies (PV strain) has the same gene organization as VS-I. Five monocistronic mRNAs plus a 3'-leader sequence of 58 nucleotides are transcribed. The untranscribed regions are a 70 nucleotide 5'-terminal region of the $\mathrm{L}$ gene, one dinucleotide spacer between $\mathrm{N}$ and NS genes, two pentanucleotide spacers between NS and $M$ genes and between $M$ and $G$ genes, and a 423 nucleotide spacer between the $\mathrm{G}$ and $\mathrm{L}$ genes. The same poly (U) stretch at the 5 '-end of each gene and sequences complementary to the 5'-end of each mRNA are present as in VS-I genome. A sixth mRNA is transcribed from the large G-L intercistronic region of infectious haematopoietic necrosis virus.

L (large), MW $\approx 190 \times 10^{3} ; \mathrm{G}$ (glycoprotein), MW $=65$ $80 \times 10^{3} ; \mathrm{N}$ (nucleoprotein, phosphorylated), $\mathrm{MW}=58$ $62 \times 10^{3}$; NS (M1, phosphorylated), MW $=35-40 \times 10^{3}$; $\mathrm{M}$ (M2, matrix), $\mathrm{MW}=22-25 \times 10^{3}$. Number of protein subunits in virion: $\mathrm{L}, 17-150 ; \mathrm{G}, 1,600-1,900 ; \mathrm{N}, 1,750$; NS (M1), 900-950; M (M2), 1,650-1,700. Enzymes in virion: transcriptase ( $\mathrm{L}+\mathrm{NS}$ proteins). A sixth protein designated nonviral (NV) is encoded by the sixth gene of infectious haematopoietic necrosis virus; function unknown.

On the basis of serum-neutralization tests, some lyssaviruses have been grouped into four serotypes; 1 (rabies), 2 (Lagos bat), 3 (Mokola), 4 (Duvenhage). The nucleocapsid proteins (N, NS) share common epitopes, however polyclonal anti-RNP as well as monoclonal anti-RNP antibodies make possible the 
distinction between groups. $\mathrm{G}$ protein provides virusneutralizing determinants.

\section{REPLICATION}

Rabies virus is neurotropic. The virus multiplies in neurons and myotubes of vertebrates. The virus also multiplies in insects. In vitro, the virus growth cycle is four times longer than VS-I cycle. Infection does not inhibit cellular macromolecular synthesis.

\section{Biological ASPECTS}

The type species (rabies virus) is transmitted through bites and rarely through aerosols or corneal grafts. The virus has been isolated from warm-blooded animals and insects.

\section{OTHER MEMBERS}

Isolated in nature from vertebrates $(\mathrm{V})$ or invertebrates $(\mathrm{I})$ :

Adelaide River (V)

Berrimah (V)

Bivens Arm (I)

Bovine ephemeral fever (I, V)

Charleville (I, V)

Coastal Plains (V)

Duvenhage (V)

Eel virus B12(V)

European bat type $1(\mathrm{~V})$

European bat type 2 (V)

Hirame rhabdovirus (V)

Humpty Doo (I)

Infectious haematopoietic necrosis (V)

Kimberley (I, V)

Kolongo (V)

Kotonkan (I)

Lagos bat (V)

Malakal (I)

Mokola (V)

Nasoule (V)

Ngaingan (I)

Oak-Vale (I)

Obodhiang (I)

Parry Creek (I)

Puchong (I)

Rochambeau (I)

Sandjimba (V)

Snakehead rhabdovirus (V)

Sweetwater Branch (I) 
Tibrogargan (I)

Viral haemorrhagic septicemia (V) (= Egtved)

\section{Probable members}
Bahia Grande serogroup
Bahia Grande (I)
Muir Springs (I)
Reed Ranch (I)

Hart Park serogroup

Flanders (I, V)

Hart Park (I, V)

Kamese (I)

Mosqueiro (I)

Mossuril ((I, V)

Kern Canyon serogroup

Barur (I, V)

Fukuoka (I)

Kern Canyon (V)

Nkolbisson (I)

Le Dantec serogroup

Keuraliba (V)

Le Dantec (V)

Sawgrass serogroup

Connecticut (I)

New Minto (I)

Sawgrass (I)

Timbo serogroup

Chaco (V)

Sena Madureira (V)

Timbo (V)

No serogroup assigned

Almpiwar (V)

Aruac (I)

Atlantic cod ulcus syndrome (V)

Bangoran (I, V)

Bimbo (V)

DakArK 7292 (I)

Gossas (V)

Joinjakaka (I)

Kannamangalam (V)

Landjia (V)

$\operatorname{Marco}(\mathrm{V})$

Mn 936-77 (I)

Navarro (V)

Oita 296 (V)

Ouango (V)

Perch rhabdovirus (V)

Rhabdovirus of blue crab (I) 


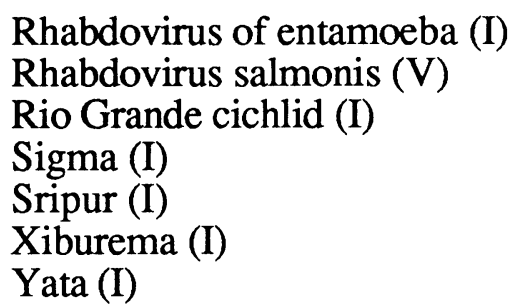

Morphology

\section{Properties of The Virus Particle}

Physiochemical
properties

Nucleic acid

Protein

\section{Antigenic properties}

Particles are bacilliform and/or bullet-shaped with a distinct prevalence of the bacilliform. Mature virions are $100-430 \mathrm{~nm}$ long and 45-100 nm wide. The nucleocapsid is formed by a helically wound ribonucleoprotein (negative-sense ssRNA plus $\mathrm{N}$ protein).

$\mathrm{S}_{20 \mathrm{w}}=774-1045$; buoyant density $=1.17-1.20$ in sucrose; inactivated by lipid solvents.

One molecule of noninfectious ssRNA (MW $=4.2-4.6 \mathrm{x}$ $10^{3}$ ). Genome of sonchus yellow net virus (subgroup B) consists of 6 ORFs (3'-N-M2-sc4-M1-G-L-5') separated by dinucleotide GG spacers lying within a common "gene junction" consensus sequence (AUUCUUUUUGGUUGG) with some relatedness to the gene junction regions of vesicular stomatitis and rabies viruses.

Viruses of subgroup A have one matrix (M) protein (MW $\left.=18-25 \times 10^{3}\right)$ and readily detectable in vitro transcriptase activity. Protein $\mathrm{L}\left(\mathrm{MW}=145-170 \times 10^{3}\right)$ is detected in some members of subgroup A. Viruses of subgroup B possess $\mathrm{M} 1$ protein $\left(\mathrm{MW}=27-44 \times 10^{3}\right)$ and $\mathrm{M} 2$ protein $\left(\mathrm{MW}=21-39 \times 10^{3}\right)$. Viruses of both groups have $\mathrm{G}$ protein $\left(\mathrm{MW}=71-93 \times 10^{3}\right)$ and $\mathrm{N}$ protein $(\mathrm{MW}=55-60$ $\left.\mathrm{x} 10^{3}\right)$.

Generally poor immunogens, but polyclonal antisera to several viruses have been prepared, and some shown to contain antibodies'to all the structural proteins. Some of the well characterized viruses have been shown to be antigenically related.

\section{REPLICATION}

Subgroup A viruses replicate in the cytoplasm in association with masses of thread-like structures 
(viroplasms) and morphogenisis occurs in association with vesicles of the endoplasmic reticulum. A nuclear phase appears to be involved in replication of some members (e.g. lettuce necrotic yellows virus) but evidence in others is lacking (e.g. barley yellow striate mosaic virus).

Subgroup B viruses multiply in the nuclei forming large granular inclusions thought to be sites of replication. Viral proteins synthesized from discrete polyadenylated mRNAs accumulate in nucleus and virus morphogenesis occurs at the inner nuclear envelope. Complete virus particles accumulate in perinuclear spaces. In protoplasts treated with tunicamycin, morphogenesis is interrupted and nucleocapsids accumulate in the nucleoplasm.

\section{Biological Aspects}

A wide variety of plants are susceptible to rhabdoviruses although each virus usually has a restricted host range. Most are transmitted by leafhoppers, planthoppers or aphids although one mite and one lacebug-transmitted virus have also been identified. Some viruses are also sap-transmissible. In all carefully examined cases, the virus has been shown to replicate in both plant and insect vector.

\section{SUBGROUPS}

Plant rhabdovirus subgroup A Plant rhabdovirus subgroup B

\begin{tabular}{lll}
\hline \hline SUBGROUP & PLANT RHABDOVIRUS & - \\
& SUBGROUP A & - \\
\hline TYPE SPECIES & $\begin{array}{l}\text { LETTUCE NECROTIC YELLOWS } \\
\text { (APHID) }(26,343)\end{array}$ & - \\
\hline
\end{tabular}

\section{OTHER MEMBERS}

Barley yellow striate mosaic (leafhopper) (312)

Broccoli necrotic yellows (aphid) (85)

Datura yellow vein

Festuca leaf streak

Maize mosaic (94)

Northern cereal mosaic (leafhopper) (322)

Sonchus

Strawberry crinkle (aphid) (163)

Wheat American striate mosaic (leafhopper) (99) 


\begin{tabular}{lll}
\hline \hline SUBGROUP & PLANT RHABDOVIRUS & - \\
& SUBGROUP B & - \\
\hline TYPE SPECIES & $\begin{array}{l}\text { POTATO YELLOW DWARF } \\
\text { (LEAFHOPPER) (35) }\end{array}$ & - \\
\hline
\end{tabular}

\section{OTHER MEMBERS}

Eggplant mottled dwarf (115)

(= Pittosporum vein yellowing and tomato vein yellowing)

Sonchus yellow net (aphid) (205)

Sowthistle yellow vein (aphid) (62)

Probable members of Plant Rhabdovirus group

Officially ungrouped, but listed according to type of vector (where known). Transmitted experimentally but not characterized physico-chemically.

Aphid

Carrot latent

Coriander feathery red vein

Lucerne enation

Raspberry vein chlorosis (174)

Leafhopper

Cereal chlorotic mottle (251)

Colocasia bobone disease

Digitaria striate

Finger millet mosaic

Maize sterile stunt

Oat striate mosaic

Papaya apical necrosis

Rice transitory yellowing (100)

Sorghum stunt

Sorghum stunt mosaic

Wheat chlorotic streak

Wheat rosette stunt

Winter wheat Russian mosaic

Lace bug

Beet leaf curl (268)

Mite

Coffee ringspot 
Not known

Chrysanthemum frutescens

Cow parsnip mosaic

Cynara

Gomphrena

Parsley latent

Pelargonium vein clearing

Pisum

Pittosporum vein yellowing

Raphanus

\section{Possible members of Plant Rhabdovirus group}

Recognized only as rhabdovirus virus-like particles:

Atropa belladonna

Callistephus chinensis chlorosis

Caper vein yellowing

Carnation bacilliform

Cassava symptomless

Chondrilla stunting

Chrysanthemum vein chlorosis

Clover enation

Cynodon chlorotic streak

Endive

Euonymus fasciation

Gerbera symptomless

Gloriosa fleck

Holcus lanatus yellowing

Honeysuckle vein chlorosis

Iris germanica leaf stripe

Ivy vein clearing

Laburnum yellow vein

Laelia red leafspot

Launea arborescens stunt

Lemon scented thyme leaf chlorosis

Lolium (ryegrass)

Lotus streak

Lupin yellow vein

Malva silvestris

Melilotus latent

Melon leaf variegation

Mentha piperita latent

Passionfruit vein clearing

Patchouli (Pogostemon patchouli) mottle

Peanut veinal chlorosis

Pigeon pea (Cajanus cajan) proliferation

Pineapple chlorotic leaf streak 
Plantain (Plantago lanceolata) mottle

Ranunculus repens symptomless

Red clover mosaic

Saintpaulia leaf necrosis

Sambucus vein clearing

Sarracenia purpurea

Strawberry latent $\mathrm{C}$

Tomato vein clearing

Triticum aestivum chlorotic spot

Vigna sinensis mosaic

Zea mays

Recognized as nonenveloped rhabdovirus-like particles:

Citrus leprosis

Orchid fleck

Dendrobium leaf streak

Phalaenopsis chlorotic spot

Derivation of Name rhabdo: from Greek rhabdos, 'rod' vesiculo: from Latin vesicula, diminutive of vesica, 'bladder, blister'.

lyssa: from Greek 'rage, rabies'

\section{REFERENCES}

Brown, F.; Bishop, D.H.L.; Crick, J.; Francki, R.I.B.; Holland, J.J.; Hull, R.; Johnson, K.M.; Martelli, G.; Murphy, F.A.; Obijeski, J.F.; Peters, D.; Pringle, C.R.; Reichmann, M.E.; Schneider, L.G.; Shope, R.E.; Simpson, D.I.H.; Summers, D.F.; Wagner, R.R.: Rhabdoviridae. Intervirology 12:1-7 (1979).

Calisher, C.H.; Karabatsos, N.; Zeller, H.G.; Digoutte, J.-P.; Tesh, R.B.; Shope, R.E.; Travassos da Rosa, A.P.A.; St. George, T.D.: Antigenic relationships among rhabdoviruses from vertebrates and hematophagous arthropods. Intervirology 30: 241257 (1989).

Dietzgen, R.G.; Francki, R.I.B.: Analysis of lettuce necrotic yellows virus structural proteins with monoclonal antibodies and concanavalin A. Virology 166: 486-494 (1988).

Dietzgen, R.G.; Hunter, B.G.; Francki, R.I.B.; Jackson, A.O.: Cloning of lettuce necrotic yellows virus RNA and identification of virus-specific polyadenylated RNAs in infected Nicotiana glutinosa leaves. J. gen. Virol. 70: 2299-2307 (1989).

Francki, R.I.B.; Milne, R.G.; Hatta, T.: Plant rhabdoviridae, In Atlas of Plant Viruses, Vol. 1, pp. 73-100. (CRC Press, Boca Raton, Fl., 1985).

Frerichs, G.N.: Rhabdoviruses of fishes; In Ahne, W.; Kurstak, E. (eds.), Viruses of Lower Vertebrates. pp. 316-332. (Springer, Berlin, Heidelberg, New York, Tokyo, 1989).

Heaton, L.A.; Hillman, B.I.; Hunter, B.G.; Zuidema, D.; Jackson, A.O.: Physical map of the genome of sonchus yellow net virus, a plant rhabdovirus with six genes and conserved gene junction sequences. Proc. Natl. Acad. Sci. USA 86: 8665-8668 (1989).

Jackson, A.O.; Francki, R.I.B.; Zuidema, D.: Biology, structure and replication of plant rhabdoviruses; In Wagner, R.R., (ed.), The Viruses, the Rhabdoviruses, pp. 427-508. (Plenum Press, New York, 1987). 
Kimura, T.; Yoshimizu, M.; Oseko, N.; Nishizawa, T.: Rhabdovirus Olivaceius (Hirame rhabdovirus); In Ahne, W.; Kurstak, E., (eds.), Viruses of Lower Vertebrates, pp. 388395. (Springer, Berlin, Heidelberg, New York, Tokyo, 1989).

Kurath, G.; Leong, J.C.: Characterization of infectious hematopoietic necrosis virus mRNA species reveals a nonvirion rhabdovirus protein. J. Virol. 53: 462-468 (1985).

Kurath, G.; Ahern, K.G.; Pearson, G.D.; Leong, J.C.: Molecular cloning of the six mRNA species of infectious hematopoietic necrosis virus, a fish rhabdovirus, and gene order determination by R-loop mapping. J. Virol. 53: 469-476 (1985).

Milne, R.G.; Masenga, V.; Conti, M.: Serological relationships between the nucleocapsids of some planthopper-borne rhabdoviruses of cereals. Intervirology 25: 83-87 (1986).

Rose, J.; Schubert, M.: Rhabdovirus genomes and their products; In Wagner, R.R., (ed.), The Viruses, the Rhabdoviruses, pp. 129-166. (Plenum Press, New York, 1987).

Tesh, R.B.; Travassos da Rosa, A.P.A.; Travassos da Rosa, J.S.: Antigenic relationship among rhabdoviruses infecting terrestrial vertebrates. J. gen. Virol. 64: 169-176 (1983).

Tordo, N.; Poch, O.; Ermine, A.; Keith, G.: Primary structure of leader RNA and nucleoprotein genes of the rabies genome: segmented homology with VSV. Nuc. Acids Res. 14: 2671-2683 (1986).

Tordo, N.; Poch, O.; Ermine, A.; Keith, G.; Rougeon, F.: Walking along the rabies genome: Is the large G-L intergenic region a remnant gene? Proc. Natl. Acad. Sci. USA, 83: 3914-3918 (1986).

Tordo, N.; Poch, O.; Ermine, A.; Keith, G.; Rougeon, F.: Completion of the rabies virus genome sequence determination: highly conserved domains among the L (polymerase) proteins of unsegmented negative-strand RNA viruses. Virology. 165: 565-576 (1988).

van Beek, N.A.M.; Lohuis, D.; Dijkstra, J.; Peters, D.: Morphogenesis of sonchus yellow net virus in cowpea protoplasts. J. Ultrastruct. Res. 90: 294-303 (1985).

Vestergard Jorhensen, P.E.; Olesen, N.J.; Ahne, W.; Lorenzen, N.: SVCV and PFR viruses: Serological examination of 22 isolates indicates close relationship between the two fish rhabdoviruses; In Ahne, W., Kurstak, E., (eds.), Viruses of Lower Vertebrates, pp. 349366. (Springer, Berlin, Heidelberg, New York, Tokyo, 1989).

Wunner, W.H.: The chemical composition and molecular structure of rabies viruses; In Baer, L., (ed.), Natural History of Rabies, pp. 31-67. (CRC Press, Boca Raton, Fl., 1991). 
Compiled by H.-D. Klenk

\begin{tabular}{lll}
\hline \hline GENUS & INFLUENZA VIRUS A AND B & - \\
\hline TYPE SPECIES & $\begin{array}{l}\text { INFLUENZAVIRUS A/PR/8/34 } \\
\text { (H1N1) }\end{array}$ & - \\
\hline
\end{tabular}

\section{Properties of the Virus Particle}

Morphology

Nucleocapsid(s) of helical symmetry and diameter 9-15 nm are enclosed within lipoprotein membrane having surface projections. Nucleoproteins of different size classes (50$130 \mathrm{~nm}$ length), with loop at each end, are extractable from virions or infected cells. Arrangement within virion uncertain, although coils of about 4-20 turns of a $7 \mathrm{~nm}$ thick material are sometimes seen in partially disrupted virus. Virions are pleomorphic, $20-120 \mathrm{~nm}$ in diameter, but filamentous forms occur having length up to several micrometers. M1 protein is believed to form a layer inside the lipid bilayer, with HA and NA glycoproteins projecting about 10-14 nm from the surface. About 500 "spikes" project from the surface of a spherical virion. Most are HA, with NA clusters interposed irregularly. The ratio of HA to NA varies, but is usually about 4 or 5 to 1 . The HA "spikes" are rods, $13.5 \mathrm{~nm}$ in length and $4 \mathrm{~nm}$ diameter. They comprise a coil of $\alpha$-helices from the three subunits extending from the membrane as a $7.6 \mathrm{~nm}$ stalk, with a globular region of antiparallel $\beta$-sheets at the distal end that contains the receptor binding site. The NA glycoprotein has a box-shaped head, $10 \times 10 \times 6 \mathrm{~nm}$, attached to a slender stalk about $100 \mathrm{~nm}$ long projecting from the membrane. Each NA subunit is composed of six topologically identical $\beta$-sheets arranged in the formation of a "propeller". Cores containing $M_{1}, \mathrm{RNP}$, and P proteins may be generated by controlled chemical disruption of virions.

Physicochemical properties
$\mathrm{MW}=250 \times 10^{6} ; \mathrm{S}_{20 \mathrm{w}}$ of nonfilamentous particles 700 800 ; density in sucrose $/ \mathrm{H}_{2} \mathrm{O} \approx 1.19 \mathrm{~g} / \mathrm{cm}^{3}$.

Virus infectivity reduced within minutes by exposure to low $\mathrm{pH}(5)$ or heat $\left(56^{\circ} \mathrm{C}\right)$. Lipid solvents and detergents (anionic, cationic, or neutral) destroy membrane integrity with resultant reduction in infectivity. Infectivity may be totally destroyed: by treatment with formaldehyde, $\beta$ propiolactone, UV light or gamma irradiation, without affecting antigenic specificity. Prolonged exposure to 
chemicals or radiation inactivates different replicative events at different rates, presumably as a result of induced lesions in individual RNA segments of different sizes. Influenza virus shows multiplicity reactivation.

Nucleic acid

Protein
Eight complete segments of linear negative sense ssRNA may be detected by gel electrophoresis. Incomplete RNA segments may be present. Chain lengths are $\approx 900$ to 2350 nucleotides for complete segments, total $\mathrm{MW} \approx 4.5 \mathrm{x}$ $10^{6}$. The largest three segments code for three polymerase proteins, three intermediate size segments code for surface glycoproteins and nucleoprotein, and the smallest two segments code for matrix protein and several nonstructural proteins. Additionally, one of the intermediate size segments (RNA 6) of influenza B viruses codes for a non-structural protein. The exact order of electrophoretic migration of the RNA segments varies with strain and electrophoretic conditions. Conserved nucleotide sequences are present at the $5^{\prime}$ and $3^{\prime}$ termini (13 and 12 nucleotides respectively in type A; 11 and 9 nucleotides respectively in type $\mathrm{B}$ ). Type A conserved $5^{\prime}$ sequence is 5'-AGUAGAAACAAGG and type B conserved 5' sequence is 5'-AGUAG-AACAA. Type A conserved 3' sequence is 3'-UCGUUUUCGUCC in most segments and 3'-UCGUUUCGUCC in segments 1-3 and in segment 7 of human virus strains. Type B conserved $3^{\prime}$ sequence is 3'-UCGUCUUCG.

Seven virion proteins. Three proteins (PB1, PB2, and PA) and one intermediate size protein (NP) are found in the RNA polymerase complex which has transcriptase and endonuclease activities: PB2 (a basic protein) contains $\approx$ 760 amino acids and recognizes 5' terminal caps of mRNA and is involved in endonucleolytic cleavage of mRNA primers. PB1 (another basic protein) contains $\approx 760$ amino acids and is involved in catalyzing the addition of nucleotides to the nascent mRNA chains. PA (an acidic protein), contains $\approx 720$ amino acids (function unknown). The nucleoprotein $(\mathrm{NP})$, which contains $\approx 500$ amino acids $\left(\mathrm{MW} \approx 56 \times 10^{3}\right)$ is phosphorylated, and is associated with the RNA genome segments in the form of a ribonucleoprotein. NP is a species-specific antigen used to identify type A and B viruses in serological tests.

Hemagglutinin (HA) is a class I membrane protein containing an amino-terminal signal sequence, which is removed by cotranslational cleavage, and a carboxyterminal transmembrane region, which anchors the glycoprotein in the cell or virion membranes. It initiates infection by binding to sialic acid-containing receptors and 
by inducing fusion of the viral envelope with cellular membranes. HA is the major surface antigen. The structure of HA, except for side chain coordinates and the C-terminal region of $\mathrm{HA}_{2}$ (see below), has been resolved for one strain to a resolution of $0.29 \mathrm{~nm}$. HA is composed of three identical subunits, each containing $\approx 550$ amino acids. The location and number of most potential N-linked glycosylation sites are not conserved among HAs of difference strains and subtypes. These changes in glycosylation are associated with masking/unmasking antigenic determinants, altered host range, and virulence. Fusion activity requires posttranslational cleavage of $\mathrm{HA}$ by cellular proteases into the disulfide-linked fragments $\mathrm{HA}_{1}(\approx 330$ amino acids $)$ and $\mathrm{HA}_{2}(\approx 220$ amino acids $)$ yielding a highly conserved sequence of 15 amino acids at the amino-terminus of $\mathrm{HA}_{2}$. Cleavability by a given protease depends, among other factors, on the number of basic amino acids present at the cleavage site. HA is acylated at the membrane-spanning region.

Neuraminidase (NA) is a second surface glycoprotein. It is a class II membrane protein containing an aminoterminal hydrophobic region which serves both as a membrane insertion signal and as a membrane anchor. NA has enzymatic activity which cleaves the alpha-glycosidic bond joining the keto group of sialic acid to D-galactose or D-galactosamine. NA is a minor surface antigen. The structure has been resolved to $0.29 \mathrm{~nm}$, except for side chain coordinates and for the $\mathrm{N}$-terminal region. NA is a tetramer. Each subunit contains 450-470 amino acids. In some cases pairs of subunits are disulfide bonded to each other, depending on the number of cysteine residues and their location relative to proteolytically cleaved sites.

The matrix or membrane $\left(\mathrm{M}_{1}\right)$ protein is $\approx 250$ amino acids, $\mathrm{MW} \approx 28 \times 10^{3}$. It is the most abundant virion protein, underlies the lipid bilayer, and is soluble in chloroform/methanol.

Both influenza $\mathrm{A}$ and $\mathrm{B}$ virus encode small integral membrane proteins of very similar structure, M2 (97 amino acid residues) and NB (100 amino acids residues) respectively. These proteins are class I integral membrane proteins that contain an uncleaved signal/anchor domain such that they are oriented with a $18-23$ residue $\mathrm{N}$-terminal extracellular domain and a C-terminal cytoplasmic domain. Both $\mathrm{M}_{2}$ and NB are expressed abundantly at the infected cell surface and both proteins are tetramers that can form higher oligomeric forms. NB contains two sides for the 
addition of $\mathrm{N}$-linked carbohydrate and both have been found to be modified by the addition of carbohydrate chains which are further modified by the addition of polylactosaminoglycan. The influenza $\mathrm{A}$ virus $\mathrm{M}_{2}$ protein transmembrane domain is linked genetically to the sensitive influenza $A$ virus to the antiviral drug amantadine hydrochloride. Although the $\mathrm{M}_{2}$ protein is abundantly expressed in influenza A virus infected cells, it is underrepresented in purified virions, but it has been found that each virion (A/WSN/33 strain) contains on average 40-63 molecules of $\mathrm{M}_{2}$. Although the presence of NS in influenza $B$ virus has not been reported, the available evidence does not rule out the presence of a small number of molecules in virions.

Influenza $\mathrm{A}$ virus $\mathrm{M}_{2}$ protein is encoded by a spiced mRNA that is processed from the colinear transcript mRNA that encodes the $M_{1}$ protein. $M_{1}$ and $M_{2}$ proteins share nine $\mathrm{N}$-terminal residues before the sequences diverge. An alternatively spliced mRNA derived from the colinear RNA segment 7 transcript is also found in virus infected cells, but the predicted polypeptide product $(9$ amino acids which would be the same as the $9 \mathrm{C}$-terminal residues of the $M_{1}$ protein) has not been identified. The influenza B virus NB glycoprotein is encoded in an overlapping reading frame on RNA segment 6 which also encodes NA. The available evidence indicates that the mRNA for NB and NA is bicistronic.

Influenza B virus RNA segment 7, in addition to encoding the $\mathrm{M}_{1}$ protein, also encodes the $\mathrm{BM}_{2}$ protein $(\mathrm{MW} \approx$ $12,000)$ that is translated from an overlapping reading frame. The $\mathrm{BM}_{2}$ protein initiation codon overlaps with the termination codon of the $\mathbf{M}_{1}$ protein in an overlapping translational stop-start pentanucleotide UAAUG. The available data indicate that expression of the $\mathrm{BM}_{2}$ protein requires 5 -adjacent termination of $\mathrm{M}_{1}$ synthesis and that a termination/reinitiation scheme is used in translation of a bicistronic mRNA. $\mathrm{BM}_{2}$ is predicted to be very different from influenza $\mathrm{A}$ virus $\mathrm{M}_{2}$ protein, as $\mathrm{BM}_{2}$ is likely to be water soluble, globular protein lacking membrane spanning hydrophobic domains.

Two non-structural proteins are found in influenza virus infected cells, $\mathrm{NS}_{1}, \mathrm{NS}_{2}$. These proteins are encoded by RNA segment 8. NS is encoded by a mRNA that is encoded by a colinear transcript derived from RNA segment 8 . $\mathrm{NS}_{1}$ is encoded by a spiced mRNA. $\mathrm{NS}_{1}$ and NS2 share ten $\mathrm{N}$-terminal residues before the sequences diverge. The coding regions for $\mathrm{NS}_{1}$ and $\mathrm{NS}_{2}$ overlap by 
70 amino acids that are translated from different reading frames. The function of these non-structural proteins in the influenza virusreplicative cycle has not been elucidated but both proteins are localized to the nucleus and nucleolus of infected cells.

\section{Lipid}

Carbohydrate

\section{Antigenic properties}

Effect on cells
$18-37 \%$ by weight of virion. Present in virion envelope. Resembles lipids of plasma membrane of host cell in composition.

$\approx 5 \%$ by weight of virion. Present as oligosaccharide side chains of glycoproteins, as glycolipids, and as mucopolysaccharide. HA (carbohydrate content $\approx 15 \%$ ) has $\mathrm{N}$-glycosidic side chains of complex and oligomannosidic type. NA (carbohydrate content $\approx 15 \%$ ) has, in addition, N-linked oligosaccharides containing $\mathrm{N}$ acetylgalactosamine. NB (carbohydrate content $36 \%$ ) has $\mathrm{N}$-linked polylactosaminoglycan. Composition of viral carbohydrates host- and virus-dependent. Carbohydrates lack sialic acid due to action of virus NA, may contain covalently bound sulphate.

The best studied antigens are NP, $\mathrm{M}_{1}$, HA, and NA. NP and $M_{1}$ are species-specific for $A$ and $B$ influenza strains. Variation occurring within HA and NA antigens has been analyzed in great detail. Fourteen subgroups of HA and nine subgroups of NA are recognized for influenza A viruses, with minimal serological crossreaction between subgroups. Additional variation occurs within subgroups, particularly for human viruses isolated in different years, although only a small number of strains of any subgroup are epidemiologically active at any time. Continual evolution of new strains occurs, and older strains apparently disappear from circulation. HA and NA antigens of influenza $B$ viruses exhibit less antigenic variation than for influenza $A$, and no subgroups are defined. Antibody to HA neutralizes infectivity. Antibody to HA neutralizes infectivity. If NA antibody is present during multicycle replication, it may inhibit virus release and, thus, reduce virus yield. Antibody to Nterminus of $\mathrm{M}_{2}$ greatly reduces virus yield in tissue culture.

Erythrocytes of many species are agglutinated by virions. Sialic acid-containing virus receptors of erythrocytes may be destroyed by NA of attached virions, resulting in elution of virus. Hemolysis of erythrocytes may be produced at $\mathrm{pH}$ of about 5 . 


\section{REPLICATION}

Attachment of virions occurs by binding of the hemagglutinin (HA) to $\mathrm{N}$-acetylneuraminic acid-containing receptors on the plasma membrane. Specificity of strains may be for 2-3 or 2-6 glycosidic linkages, depending on sequence of receptor site in HA. Entry is by endocytosis into endosomal vesicles. Fusion between the virus envelope and the endosomal membrane is apparently triggered by a conformational change that occurs only in cleaved HA proteins when the $\mathrm{pH}$ is reduced to about 5 . This leads to release of the transcription complex into the cytoplasm.

Transcriptase complex synthesises messenger RNA transcripts in the cell nucleus; this process is primed by 5'methyl-guanosine (capped) RNA fragments 8-15 nucleotides in length. These primers are generated from host heterogeneous nuclear RNA by a viral endonuclease activity associated with the viral PB2 protein. Virusspecific messenger RNA synthesis is inhibited by actinomycin $\mathrm{D}$ or $\alpha$-amanitin due to blockage of host DNA-dependent transcription and a presumed lack of newly synthesized substrate for viral endonuclease to generate primers. Viral-specific mRNA is polyadenylated at the 3 ' termini, and lacks sequences corresponding to the 5 -terminal 16 nucleotides of the corresponding vRNA segment. The mechanism for early termination during transcription of mRNA is unknown.

Complementary RNA molecules which act as templates for new vRNA synthesis are complete transcripts of vRNA, and are neither capped nor polyadenylated. These RNAs are also probably synthesized in the nucleus of infected cells.

Protein synthesis occurs in the cytoplasm. Nucleoprotein and $\mathrm{NS}_{1}$ protein antigens accumulate in the nucleus during the first hours of infection, then migrate to the cytoplasm. Inclusions of $\mathrm{NS}_{1}$ may form. $\mathrm{M}_{1}$ has also been observed in nucleus. $\mathrm{HA}$ and NA proteins migrate through the Golgi apparatus to localized regions of the plasma membrane where new virions form by budding, incorporating $\mathrm{M}$ protein and RNP's which have aligned below regions of plasma membrane containing $\mathrm{HA}$ and NA on their surface. $M_{1}$ protein of influenza $A$, and NB protein of influenza $B$, also accumulate after intracellular transport by the exocytotic pathway on plasma membranes. Budding is from the apical surface in polarized cells. Gene reassortment occurs during mixed 
infections with virus of the same species, but not between virus species. True recombination of RNA has also been detected.

\section{Biological Aspects}

\section{Host range}

Influenza A viruses naturally infect man, and several other mammalian species and a wide variety of avian species. Some interspecies transmission believed to occur. Epidemics of respiratory disease in man have been caused by influenza $A$ viruses having antigenic composition $\mathrm{H} 1 \mathrm{~N} 1, \mathrm{H} 2 \mathrm{~N} 2, \mathrm{H} 3 \mathrm{~N} 2$, and possibly H3N8. Influenza $\mathrm{A}$ viruses of subtype $\mathrm{H} 7 \mathrm{~N} 7$ and $\mathrm{H} 3 \mathrm{~N} 8$ (previously designated equine 1 and equine 2 viruses) cause outbreaks of respiratory diseases in horses. Type A (H1N1) viruses, and type A (H3N2) viruses have been frequently isolated from swine. The $\mathrm{H} 1 \mathrm{~N} 1$ viruses isolated from swine in recent years appear to be of three general categories: those closely related to classical "swine influenza" and which cause occasional human cases (e.g., A/New Jersey/8/76like strains), those first recognized in avian specimens (e.g., A/Alberta/35/76-like strains), but which have caused outbreaks among swine in France, and those resembling viruses isolated from epidemics in man since 1977 (e.g., A/USSR/90/77-like strains). H3N2 viruses from swine all appear to contain HA and NA genes closely related to those from human epidemic strains. Type A (H7N7 and H4N5) viruses have caused outbreaks in seals, with virus spread to nonrespiratory tissue in this host. Such virus has accidentally infected the conjunctiva of one laboratory worker. Pacific Ocean whales were reportedly infected with type A (H1N1) virus. Other influenza subtypes have also been isolated from lungs of Atlantic Ocean whales in North America. Type A (H10N4) virus has caused outbreaks in mink. All subtypes of HA and NA, in many different combinations, have been identified in isolates from avian species, particularly chickens, turkeys, and ducks. Pathology in avian species varies from unapparent infection (often involving replication in, and probable transmission via, the intestinal tract), to virulent infections (only observed with subtypes $\mathrm{H} 5$ and $\mathrm{H} 7$ ) with spread to many tissues and high mortality rates. Structure of the HA protein, in particular the specificity of its receptor binding site and its cleavability by naturally occurring tissue proteases, appears critical in determining the host range of the virus. In addition, interactions between gene products determine the outcome of infection. Thus, host range of influenza viruses is generally unpredictable. Interspecies transmission has apparently occurred in some instances 
without genetic reassortment (e.g., H1N1 virus from swine to man and vice versa, or $\mathrm{H} 3 \mathrm{~N} 2$ virus from man to swine), but in other cases of interspecies transmission it is proposed that reassortment in hosts infected with more than one strain may have resulted in viruses with new constellations of genes having altered host ranges or epidemic properties (e.g., H3N2 viruses probably derived in 1968 by reassortment of human $\mathrm{H} 2 \mathrm{~N} 2$ viruses and an unknown $\mathrm{H} 3$-containing virus; seal $\mathrm{H} 7 \mathrm{~N} 7$ virus probably derived by reassortment of two or more avian influenza viruses; and reassortment of human $\mathrm{H} 1 \mathrm{~N} 1$ and $\mathrm{H} 3 \mathrm{~N} 2$ viruses in 1978 led to outbreaks of virus with H1N1 surface antigens but 4 or 5 genes of H3N2 origin). Laboratory animals that may be artificially infected with influenza A viruses include ferrets, mice, hamsters, and guinea pigs as well as some small primates such as squirrel monkeys.

Influenza B strains appear to naturally infect only man and cause epidemics every few years. They also artificially infect laboratory rodents. Most type A and B strains grow in the amniotic cavity of embryonated hen's eggs, and after adaptation type A and B viruses grow in the allantoic cavity. Primary kidney cells from monkeys, humans, calves, pigs, and chickens support replication of many virus strains. Host range may be extended by addition of trypsin to growth medium, so that replication also can be obtained in some continuous cell lines. Clinical specimens from influenza-infected hosts sometimes contain subpopulations of virus with minor sequence differences in at least their HA protein. These subpopulations may differ in their receptor specificity or their propensity for growth in different host cells.

Transmission Aerosol (human and most non-aquatic hosts) or waterborne (ducks).

\begin{tabular}{lll}
\hline \hline GENUS & INFLUENZA VIRUS C & - \\
\hline TYPE SPECIES & INFLUENZA VIRUS & - \\
& C/TAYLOR/1233/47 & \\
\hline
\end{tabular}

Properties of The Virus Particle

Morphology Size generally similar to influenza A and B viruses with reticular structure often, but not always, observed on virion surface. 
Nucleic acid Seven molecules of negative sense ssRNA. Size $=975$ 2,350 nucleotides, with total molecular weight of RNA = $4-5 \times 10^{6}$. RNA segments $1-3$ code for 3 polymerase proteins, segments 4,5 and 6 code for envelope glycoprotein, nucleoprotein, and membrane protein, respectively, and segment 7 codes for 2 non-structural proteins. Nucleotide sequences at the $5^{\prime}$ and $3^{\prime}$ termini conserved between segments, and are 5'AGCAGUAGCAA and 3'UCGUUUCGUC, respectively. These sequences closely resemble those of the influenzavirus $\mathrm{A}$ and $\mathrm{B}$ genus.

Protein

Six virion proteins. Nucleocapsid contains polymerase proteins $\mathrm{PB}_{2}$ (774 amino acids), $\mathrm{PB}_{1}$ (754 amino acids), $\mathrm{PB}_{3}$ (709 amino acids) and nucleoprotein (NP) (565 amino acids). The single glycoprotein (HEF) present in the viral envelope has 3 functions. (1) it hemagglutinates and initiates infection by binding to 9-0-acetyl-N-acetylneuraminic acid as the essential receptor compound, (2) it has neuraminate 0 -acetyl esterase activity which functions as receptor destroying enzyme, (3) it induces membrane fusion. HEF, which is about 100 amino acids longer than $\mathrm{HA}$ of influenza A and B viruses, is synthesized as a precursor polypeptide $\approx 655$ amino acids long $\left(\approx 72 \times 10^{3}\right)$ including a cotranslationally cleaved hydrophobic leader sequence. Posttranslational cleavage produces a large fragment $\left(\mathrm{HEF}_{1}\right)$ of $\approx 48 \times 10^{3}$ and a small fragment $\left(\mathrm{HEF}_{2}\right)$ of $22.5 \times 10^{3}$ with an $\mathrm{N}$-terminus resembling $\mathrm{F}_{1}$ polypeptide of paramyxoviruses. $\mathrm{N}$ - and C-termini of $\mathrm{HEF}_{2}$ are hydrophobic, similar to $\mathrm{HA}_{2}$ of influenza $\mathrm{A}$ and $\mathrm{B}$ viruses. 8 potential $\mathrm{N}$-glycosylation sites have been identified, 6 in $\mathrm{HEF}_{1}$ and 2 in $\mathrm{HEF}_{2}$. Homologies with influenza A and B HA are largely confined to the $\mathrm{N}$ - and $\mathrm{C}$-termini, and to 6 of the cysteines. Virions contain also large amounts of internal membrane protein which, unlike influenza $A$ and $B M_{1}$, is translated from spliced mRNA.

Non structural proteins. A colinear and a spliced mRNA are derived from RNA 7 encoding the non-structural proteins $\mathrm{NS}_{1}$ (286 amino acids) and $\mathrm{NS}_{2}$ (122 amino acids), respectively.

\section{REPLICATION}

Like influenzaviruses A and B, replication can be inhibited by agents that interfere with host cell DNA-dependent RNA synthesis. 


\section{Biological ASPECTS}

Host range Infection of man is common in childhood. Occasional outbreaks, but not epidemics, have been detected. Swine in China reported to be infected by viruses similar to contemporary human strains.

\section{OTHER MEMBERS OF THE FAMILY}

D, comprising tick borne viruses (e.g. Dhori and Thogoto viruses) occasionally infecting man. Such viruses, morphologically resembling influenza viruses, contain 6 or 7 ss RNA segments of negative sense, which have 3 ' and 5 ' ends similar to those of other orthomyxoviridae. Based on nucleotide sequences that have been compared to those of influenza A, B and C viruses, segments $2,4,5$, and 6 of Dhori virus have been predicted to code for PB1, the glycoprotein, the nucleoprotein, and the matrix protein, respectively. The sequenced segments 3 and 4 of Thogoto virus show evolutionary relatedness to PA and to the major surface glycoproteins of orthomyxoviridae, respectively.

Derivation of Name ortho: from Greek orthos "straight, correct" myxo: from Greek myxa "mucus" (relating to activity of hemagglutinin and neuraminidase).

influenza: Italian form of Latin influentia, "epidemic". So used because epidemics were thought to be due to astrological or other occult "influences".

\section{REFERENCES}

Fuller, F.J., Clay, W.C., Freedman, E.Z., McEntree, M., and Barnes, J.A.: Nucleotide sequence of the major structural protein genes of the tick-borne, othomyxo-like Dhori/Indian/1313/61 virus. In Kolakovsky, D., Mahy, B.W.J. (eds.), Genetics and pathogenicity of negative strand viruses pp. 279-286 (Elsevier, Amsterdam, 1989).

Kingsbury, E.D.: Influenza. (Plenum Medical Book Company, New York, London, 1987).

Krug, R.M.: The Influenza Viruses. In Fraenkel-Conrat, H.; Wagner, R.R. (eds.), The viruses (Plenum Press, New York, 1990).

Palese, P.; Kingsbury, D.W.: Genetics of influenza viruses. (Springer, Wien, New York, 1983). 
Morphology

Physicochemical properties

Nucleic acid

Proteins

\section{Lipid}

Carbohydrate

\section{Antigenic properties}

Effect of virus on vertebrate cells
Reported by C.H. Calisher

\section{Properties of the Virus Particle}

Spherical or pleomorphic enveloped particles $(80-100 \mathrm{~nm}$ in diameter) with glycoprotein surface projections; ribonucleocapsids composed of 3 circular, helical strands, 2-2.5 $\mathrm{nm}$ diameter, sometimes supercoiled, $0.2-3 \mu \mathrm{m}$ in length depending on arrangement.

$\mathrm{MW}=300-400 \times 10^{6} ; \mathrm{S}_{20 \mathrm{w}}=350-500 ;$ buoyant density in $\mathrm{CsCl} \approx 1.2 \mathrm{~g} / \mathrm{cm}^{3}$. Sensitive to lipid solvents and detergents.

Three molecules (large [L], medium [M], and small [S]) of negative or ambisense ssRNA. Ends are hydrogenbonded, RNA and nucleocapsids circular. Differences exist between terminal nucleotide sequences of gene segments of viruses of different genera. $\mathrm{MW}=2.2-4.9$ (6.5-14.4 kb), $1.0-2.3(3.2-6.3 \mathrm{~kb})$ and $0.28-0.8 \times 10^{6}$ (0.8-2.0 kb), respectively; $1-2 \%$ by weight.

Usually 4 consisting of 2 external glycoproteins (G1, G2), a nucleocapsid protein $(\mathrm{N})$, and a large protein $(\mathrm{L})$ which is presumably a transcriptase. Transcriptase activity present in virion.

$20-30 \%$ by weight; forms lipoprotein envelope, which is cell-derived.

$2-7 \%$ by weight; components of the glycoproteins and glycolipids.

Hemagglutinin and neutralizing antigenic determinants present on viral glycoproteins. CF antigenic determinants principally associated with nucleocapsid protein.

Some induce cell fusion at low $\mathrm{pH}$. Most cause cytopathic effects; hantaviruses do not cause cytopathic effects. Some members have ion-dependent hemagglutinating activity.

\section{REPLICATION}

Replicate in cytoplasm. Host RNA sequence shown to prime viral mRNA synthesis. Some code for nonstructural (NS) protein(s). Genetic reassortment demonstrated for certain members. Virion RNA segments 
are transcribed in the cytoplasm to complementary mRNAs by the virion transcriptase. The L RNA encodes the $\mathrm{L}$ protein, a single open reading frame in the $M$ RNA encodes the glycoproteins, which are cotranslationally cleaved to $\mathrm{G} 1$ and $\mathrm{G} 2$. The $\mathrm{S}$ RNA encodes the $\mathrm{N}$ protein and, in some instances, a nonstructural protein $\mathrm{NS}_{\mathrm{S}}$. Mature by budding into smooth-surfaced vesicles in or near the Golgi region but maturation at the plasma membrane has also been observed.

\section{Biological Aspects}

Host range

Various arthropods and/or warm or cold-blooded vertebrates.

Transmission Mosquitoes, ticks, phlebotomine flies and other arthropod vectors. Transovarial and venereal transmission demonstrated for some mosquito-borne viruses. Aerosol infection occurs in certain situations or is the principal means of transmission for some viruses. In some instances, avian host and/or vector movements may result in virus dissemination. No arthropod vector demonstrated in Hantavirus transmission.

\section{GENERA}

Bunyamwera supergroup Bunyavirus

Sandfly fever and Uukuniemi group Phlebovirus

Nairobi sheep disease group Nairovirus

Hantaan group Hantavirus

Tomato spotted wilt group Tospovirus

\begin{tabular}{llc}
\hline \hline GENUS & BUNYAMWERA SUPERGROUP & BUNYAVIRUS \\
\hline TYPE SPECIES & BUNYAMWERA VIRUS & - \\
\hline
\end{tabular}

\section{Properties of The Virus Particle}

Nucleic acid $\quad$ L RNA $=2.7-3.1 \times 10^{6}(\approx 7 \mathrm{~kb}) ; \mathrm{M}$ RNA $=1.8-2.3 \times 10^{6}$ $(4.45-4.54 \mathrm{~kb}) ; \mathrm{S}$ RNA $=0.28-0.50 \times 10^{6}(0.85-0.99 \mathrm{~kb})$; 3 -terminal nucleotide sequences of $\mathrm{L}, \mathrm{M}$ and $\mathrm{S}$ gene segments = UCAUCACAUGA..., 5'- terminal nucleotide sequences of $M$ and $S$ gene segments = AGUAGUGUGCU...

\section{Protein}

$\mathrm{G} 1=108-120 \times 10^{3} ; \mathrm{G} 2=29-41 \times 10^{3} ; \mathrm{N}=19-25 \times 10^{3}$; $\mathrm{L} \approx 200 \times 10^{3}$. Both glycoproteins and $15-18 \times 10^{3} \mathrm{NS}_{\mathrm{M}}$ derived from $\mathrm{M}$ RNA; $\mathrm{N}$ and $\mathrm{NS}_{\mathrm{S}}$ coded in overlapping reading frames by S RNA. L protein coded by L RNA. 


\section{REPLICATION}

Viral induced mRNA species (1 per RNA segment) are subgenomic, viral-complementary in sequence and have host mRNA-derived 5 ' terminal sequences.

\section{Biological Aspects}

Host range

Various vertebrate species; also insects, primarily mosquitoes but occasionally other arthropods, e.g. ceratopogonids in the genus Culicoides, phlebotomines and ticks.

Virulence

Primarily determined by viral M RNA gene products (glycoproteins).

\section{OTHER MEMBERS}

There are 18 antigenic groups of the genus Bunyavirus (at least 162 viruses) and 4 ungrouped viruses. Serologically unrelated to members of other genera. Mostly mosquitotransmitted; some (Tete group) tick-transmitted. Some transmitted transovarially in arthropods.

The groups are:

Anopheles A (12): Anopheles A, Las Maloyas, Lukuni, Tacaiuma, Trombetas, Virgin River, CoAr3624, CoAr1071, CoAr3627, ColAn57389, SPAr2317, H32580

Anopheles B (2): Anopheles B, Boraceia

Bakau (5): Bakau, Ketapang, Nola, Tanjong Rabok, Telok Forest

Bunyamwera (32): Anhembi, Batai, Birao, Bozo, Bunyamwera, Cache Valley, Fort Sherman, Germiston, Guaroa, Iaco, Ilesha, Kairi, Lokern, Macaua, Maguari, Main Drain, Mboke, Ngari, Northway, Playas, Santa Rosa, Shokwe, Sororoca, Taiassui, Tensaw, Tlacotalpan, Tucunduba, Wyeomyia, Xingu, Ag83-1746, BeAr328208, CbaAr426

Bwamba (2): Bwamba, Pongola

C (14): Apeu, Bruconha, Caraparu, Gumbo Limbo, Itaqui, Madrid, Marituba, Murutucu, Nepuyo, Oriboca, Ossa, Restan, Vinces, 63U11 
California (13): California encephalitis, Inkoo, Jamestown Canyon, Keystone, La Crosse, Melao, San Angelo, Serra do Navio, snowshoe hare, South River, Tahyna, trivittatus, AG83-497

Capim (10): Acara, Benevides, Benfica, Bushbush, Capim, Guajara, Juan Diaz, Moriche, GU71u344, GU71u350

Gamboa (8): Alajuela, Brus Laguna, Gamboa, Pueblo Viejo, San Juan, 75V-2374, 75V-2621, 78V-2441

Guama (12): Ananindeua, Bertioga, Bimiti, Cananeia, Catu, Guama, Guaratuba, Itimirim, Mahogany Hammock, Mirim, Moju, Timboteua

Koongol (2): Koongol, Wongal

Minatitlan (2): Minatitlan, Palestina

Nyando (2): Nyando, Eret-147

Olifantsvlei (5): Bobia, Botambi, Dabakala, Olifantsvlei, Oubi

Patois (7): Abras, Babahoyo, Estero Real, Pahayokee, Patois, Shark River, Zegla

Simbu (24): Aino, Akabane, Buttonwillow, Douglas, Facey's Paddock, Ingwavuma, Inini, Kaikalur, Manzanilla, Mermet, Oropouche, Para, Peaton, Sabo, Sango, Sathuperi, Shamonda, Shuni, Simbu, Thimiri, Tinaroo, Utinga, Utive, Yaba-7

Tete (6): Bahig, Batama, Matruh, Tete, Tsuruse, Weldona Turlock (4): Lednice, Turlock, Umbre, Yaba-1

Ungrouped (4): Kaeng Khoi, Leanyer, Mojui dos Campos, Termeil 


\begin{tabular}{llc}
\hline \hline GENUS & SANDFLY FEVER AND & PHLEBOVIRUS \\
& UUKUNIEMI GROUP VIRUSES & \\
\hline TYPE SPECIES & SANDFLY FEVER (SF) & - \\
& SICILIAN VIRUS & \\
\hline
\end{tabular}

\section{Properties of the Virus Particle}

Nucleic acid

L RNA $=2-2.8 \times 10^{6}(6.5-8.5 \mathrm{~kb}) ; \mathrm{M}$ RNA $=1.1-2.2 \times$ $10^{6}(3.2-4.3 \mathrm{~kb}) ; \mathrm{S}$ RNA $=0.4-0.8 \times 10^{6}(1.7-1.9 \mathrm{~kb}) ; 3^{\prime}-$ terminal nucleotide sequences of $\mathrm{L}, \mathrm{M}$ and $\mathrm{S}$ gene segments = UGUGUUUC..., 5'-terminal nucleotide sequences of $\mathrm{M}$ gene segment $=$ ACACAAAGAC...

Protein $\quad \mathrm{G} 1=55-75 \times 10^{3} ; \mathrm{G} 2=50-70 \times 10^{3} ; \mathrm{N}=20-30 \times 10^{3} ; \mathrm{L}$ $=145-200 \times 10^{3}$. Both glycoproteins coded by M RNA; the $\mathrm{N}$ protein coded by $\mathrm{S}$ RNA.

\section{REPLICATION}

Virion $\mathrm{M}$ and $\mathrm{S}$ RNA segments are transcribed into complementary mRNAs by virion RNA transcriptase. The S RNA exhibits an ambisense coding strategy, i.e. it is transcribed by virion RNA polymerase to a subsegmental viral complementary mRNA that encodes the $\mathrm{N}$ protein and to a subsegmental viral-sense mRNA that encodes a nonstructural $\left(\mathrm{NS}_{\mathrm{S}}\right)$ protein $(\mathrm{MW} \approx 30,000)$, the function of which is unknown. At least the M and S mRNA contain host mRNA-derived 5' primer sequences. Viruses of the sandfly fever group but not of the Uukuniemi group have a pre-glycoprotein coding region $\left(\mathrm{NS}_{\mathrm{M}}\right)$ of unknown function.

\section{Biological ASPECTS}

Host range Sandfly fever group viruses have been isolated from various vertebrate species and from phlebotomines and occasional alternate arthropods, e.g. mosquitoes or ceratopogonids in the genus Culicoides. Uukuniemi serogroup viruses are isolated from various vertebrate species and from ticks. Virulence factors are coded by genes on each of the RNA species.

\section{OTHER MEMBERS}

There are 8 antigenic complexes (at least 23 viruses) within the sandfly fever group; 16 viruses related to sandfly fever Sicilian virus have not been assigned to an antigenic complex. Uukuniemi group viruses belong to a single serogroup (12 viruses). Low-level antigenic cross- 
reactivity occurs between certain sandfly fever group and certain Uukuniemi group viruses but sandfly fever and Uukuniemi group viruses are antigenically unrelated to members of other genera. Sandfly fever group viruses are transmitted by phlebotomines, mosquitoes or ceratopogonids of the genus Culicoides; Uukuniemi group viruses are transmitted by ticks.

Uukuniemi and sandfly fever group viruses are related in that (i) they share the same ambisense coding strategy for the S RNA segment, (ii) they have identical 5' and 3' terminal nucleotide sequences, (iii) they display low, but significant homology between the glycoproteins, (iv) the $\mathrm{N}$ proteins show a high degree of homology, and (v) certain members of each group are antigenically related to certain members of the other group.

The complexes are (sandfly fever group):

Sandfly fever Naples (4): Karimabad, Sandfly fever Naples, Tehran, Toscana

Bujaru (2): Bujaru, Munguba

Candiru (6): Alenquer, Candiru, Itaituba, Nique, Oriximina, Turuna

Chilibre (2): Cacao, Chilibre

Frijoles (2): Frijoles, Joa

Punta Toro (2): Buenaventura, Punta Toro

Rift Valley fever (3): Belterra, Icoaraci, Rift Valley fever

Salehabad (2): Arbia, Salehabad

No complex assigned (16): Aguacate, Anhanga, Arboledas, Arumowot, Caimito, Chagres, Corfou, Gabek Forest, Gordil, Itaporanga, Odrenisrou, Pacui, Rio Grande, Saint-Floris, Sandfly fever Sicilian, Urucuri

Uukuniemi group (12): Grand Arbaud, Manawa, Murre, Oceanside, Ponteves, Precarious Point, St. Abbs Head, Uukuniemi, Zaliv Terpeniya, EgAn1825-61, Fin V-707, RML 105355. 


\begin{tabular}{llc}
\hline \hline GENUS & NAIROBI SHEEP DISEASE AND & NAIROVIRUS \\
& RELATED VIRUSES & \\
\hline TYPE SPECIES & CRIMEAN-CONGO & - \\
& $\begin{array}{l}\text { HEMORRHAGIC FEVER } \\
\text { (CCHF) VIRUS }\end{array}$ & \\
\hline
\end{tabular}

\section{Properties of The Virus Particle}

Nucleic acid $\quad$ L RNA $=4.1-4.9 \times 10^{6}(11.0-14.4 \mathrm{~kb}) ; \mathrm{M}$ RNA $=1.5-2.3$ x $10^{6}(4.4-6.3 \mathrm{~kb}) ; \mathrm{S}$ RNA $=0.6-0.7 \times 10^{6}(1.7-2.1 \mathrm{~kb})$; 3 '-terminal nucleotide sequences of $\mathrm{L}, \mathrm{M}$ and $\mathrm{S}$ gene segments $=$ AGAGAUUCU..

Protein

$\mathrm{G} 1=72-84 \times 10^{3} ; \mathrm{G} 2=30-40 \times 10^{3} ; \mathrm{N}=48-54 \times 10^{3} ; \mathrm{L}$ $=145-200 \times 10^{3}$.

\section{REPLICATION}

At least two non-structural glycoprotein precursors synthesized in infected cells. Nucleocapsid protein coded by S RNA in viral-complementary sequences.

\section{Biological ASPECTS}

Host range Various vertebrate species; primarily ticks but occasional alternate arthropod species, mosquitoes and ceratopogonids of the genus Culicoides.

\section{OTHER MEMBERS}

There are 7 antigenic groups of the genus Nairovirus (at least 33 viruses). Serologically unrelated to members of other genera. Most are tick-transmitted.

The groups are:

Crimean-Congo hemorrhagic fever (3): Crimean-Congo hemorrhagic fever, Hazara, Khasan

Dera Ghazi Khan (6): Abu Hammad, Abu Mina, Dera Ghazi Khan, Kao Shuan, Pathum Thani, Pretoria

Hughes (10): Farallon, Fraser Point, Great Saltee, Hughes, Puffin Island, Punta Salinas, Raza, Sapphire II, Soldado, Zirqa

Nairobi sheep disease (2): Dugbe, Nairobi sheep disease

Qalyub (3): Bandia, Omo, Qalyub 
Sakhalin (7): Avalon, Clo Mor, Kachemak Bay, Paramushir, Sakhalin, Taggert, Tillamook.

Thiafora (2): Erve, Thiafora

\begin{tabular}{llc}
\hline \hline GENUS & HANTAAN & HANTAVIRUS \\
& AND RELATED VIRUSES & \\
& (HEMORRHAGIC FEVER & \\
& WITH RENAL SYNDROME) & \\
\hline TYPE SPECIES & HANTAAN VIRUS & - \\
\hline
\end{tabular}

\section{Properties of the Virus Particle}

Nucleic acid L RNA $=2.2-2.9 \times 10^{6}(6.5-8.5 \mathrm{~kb}) ; \mathrm{M}$ RNA $=1.4-1.9 \mathrm{x}$ $10^{6}(\approx 3.6 \mathrm{~kb}) ; \mathrm{S}$ RNA $=0.6-0.75 \times 10^{6}(\approx 1.7 \mathrm{~kb}) ; 3^{\prime}-$ terminal nucleotide sequences of $\mathrm{L}, \mathrm{M}$ and $\mathrm{S}$ gene segments $=$ AUCAUCAUCUG..., 5'- terminal nucleotide sequences of $\mathrm{M}$ and $\mathrm{S}$ gene segments = UAGUAGUA...

Protein $\quad \mathrm{G} 1=68-76 \times 10^{3} ; \mathrm{G} 2=52-58 \times 10^{3} ; \mathrm{N}=48-54 \times 10^{3}$; $\mathrm{L}=200 \times 10^{3}$. N protein coded by S RNA; both glycoproteins coded by M RNA.

\section{REPLICATION}

Nucleocapsid protein coded by S RNA in viralcomplementary sequence; M RNA codes for both G1 and G2 in a single open reading frame in viral-complementary sense RNA. S RNA encodes nucleo-protein in viralcomplementary sense sequence. There is no evidence for nonstructural proteins.

\section{Biological Aspects}

Host range Various vertebrate species, primarily rodents and humans; no known arthropod vector.

\section{OTHER MEMBERS}

There is 1 recognized group within the genus Hantavirus (at least 6 viruses), plus a large number of isolates not yet assigned to an antigenic complex. Serologically unrelated to members of other genera. Probably no arthropod vector involved in transmission.

The group is:

Hantaan group (6): Hantaan, Leaky, Seoul, Prospect Hill, Puumala, Thottapalayam 


\begin{tabular}{llc}
\hline \hline GENUS & TOMATO SPOTTED & TOSPOVIRUS \\
& WILT GROUP & - \\
\hline TYPE SPECIES & TOMATO SPOTTED & \\
& WILT VIRUS (39) & \\
\hline
\end{tabular}

\section{Properties of the Virus Particle}

Nucleic acid

$\mathrm{L}$ RNA $=2.7 \times 10^{6}(8.2 \mathrm{~kb}) ; \mathrm{M} \mathrm{RNA}=1.5 \times 10^{6}(5.2 \mathrm{~kb})$; $S$ RNA $=0.9 \times 10^{6}(3.4 \mathrm{~kb})$.

Protein

$\mathrm{G} 1=78 \times 10^{3} ; \mathrm{G} 2=58 \times 10^{3}$ (another protein $[\mathrm{G} 2 \mathrm{~b}=52$ $\left.\mathrm{x} 10^{3}\right]$ is found in some preparations, $\mathrm{G} 2$ is then denoted G2a); $\mathrm{N}=28.8 \times 10^{3} ; \mathrm{L}=200 \times 10^{3}$. Glycoproteins probably coded by M RNA; nonstructural protein (52.4 x $10^{3}$ ) coded by S RNA. Messenger RNA has been detected.

\section{REPLICATION}

The S RNA exhibits an ambisense coding strategy; the $M$ RNA has a negative sense coding strategy. The nucleocapsid protein is coded in the viral complementary sequence and a putative nonstructural protein coded in a viral-sense sequence on the S RNA. The M RNA codes in the viral-complementary sequence for one large protein precursor from which at least one glycoprotein is processed. Genome organization similar to that of viruses of the genus Phlebovirus but tomato spotted wilt virus lacks sequence homology with coding and non-coding regions of phleboviruses. Particle morphogenesis occurs in clusters in the cisternae of the endoplasmic reticulum of host cells. Nucleocapsid material may accumulate in the cytoplasm in dense masses.

\section{Biological ASPECTS}

Host range

At least 9 species of thrips have been reported to transmit the virus; the virus can be transmitted experimentally by sap inoculation. More than 360 plant species belonging to 50 families are known to be susceptible to infection with tomato spotted wilt virus.

\section{OTHER MEMBERS}

Not known. 
Other possible members of family
At least 7 groups (19 viruses) and 22 ungrouped viruses. Not shown to be antigenically related to members of other Bunyaviridae genera. For most, no biochemical characterization of the viruses has been reported to confirm their family or generic status.

The groups are:

Bhanja (3): Bhanja, Forecariah, Kismayo

Kaisodi (3): Kaisodi, Lanjan, Silverwater

Mapputta (4): Gan Gan, Mapputta, Maprik, Trubanaman

Okola (2): Okola, Tanga

Resistencia (3): Antequera, Barranqueras, Resistencia

Upolu (2): Aransas Bay, Upolu

Yogue (2): Yogue, Kasokero

Ungrouped viruses (22): Bangui, Batken, Belem, Belmont, Bobaya, Caddo Canyon, Chim, Enseada, IssykKul (Keterah), Kowanyama, Lone Star, Pacora, Razdan, Salanga, Santarem, Sunday Canyon, Tai, Tamdy, Tataguine, Wanowrie, Witwatersrand, Yacaaba.

Derivation of Name bunya: from Bunyamwera; place in Uganda, where type virus was isolated.

nairo: from Nairobi sheep disease; first reported disease caused by member virus.

phlebo: refers to phlebotomine vectors of sandfly fever group viruses; Greek phlebos, "vein".

hanta: from Hantaan; river in South Korea near where type virus was isolated.

tospo: derived from To (Tomato) spo (spotted wilt), the type member of the genus. 


\section{REFERENCES}

Arikawa, J.; Lapenotiere, H.F.; Iacono-Connors, L.; Wang, M.; Schmaljohn, C.S.: Coding properties of the $\mathrm{S}$ and $\mathrm{M}$ genome segments of Sapporo Rat virus: comparison to other causative agents of Hemorrhagic fever with renal syndrome. Virology 176: 114-125 (1990).

Bishop, D.H.L.: Bunyaviridae and their replication, Part I. Bunyaviridae; In Fields, B.N.; Knight, J.C. (eds.), Virology, Vol. 1, 2nd edn., pp. 1155-1173 (Raven Press, New York, 1990).

Bishop, D.H.L.; Shope, R.E.: Bunyaviridae; In Fraenkel-Conrat, H.; Wagner, R.R. (eds.), Comprehensive Virology, Vol. 14, pp. 1-156 (Plenum Press, New York, 1979).

de Haan, P.; Wagemakers, L.; Peters, D.; Goldbach, R.: Molecular cloning and terminal sequence determination of the S and M RNAs of tomato spotted wilt virus. J. gen. Virol. 70: 3469-3473 (1989).

de Haan, P.; Wagemakers, L.; Peters, D.; Goldbach, R.: The S RNA segment of tomato spotted wilt virus has an ambisense character. J. gen. Virol. 71: 1001-1007 (1990).

Elliott, R.M.: Molecular biology of the Bunyaviridae. J. gen. Virol. 71: 501-522 (1990).

Francki, R.I.B.; Hatta, T.: Tomato spotted wilt virus; In Kurstak, E. (ed.), Handbook of Plant Virus Infections and Comparative Diagnosis, pp. $491-512$ (Elsevier/North-Holland, Amsterdam, 1981).

Gonzalez-Scarano, F.; Nathanson, N.: Bunyaviruses. In Fields, B.N.; Knight, J.C. (eds.), Virology, Vol.1, 2nd edn., pp. 1195-1228 (Raven Press, New York, 1990).

Karabatsos, N.: International catalogue of arboviruses including certain other viruses of vertebrates. (American Society of Tropical Medicine and Hygiene, San Antonio, Tx, USA, 1985).

Marriott, A.C.; Ward, V.K.; Nuttall, P.A.: The S RNA segment of sandfly fever Sicilian virus: evidence for an ambisense genome. Virology. 169: 341-345 (1989).

Milne, R.G.; Francki, R.I.B.: Should tomato spotted wilt virus be considered as a possible member of the family Bunyaviridae? Intervirology 22: $72-76$ (1984).

Pettersson, R.F.; Gahmberg, N.; Kuismanen, E.; Kääriäinen, L.; Ronnholm, R.; Saraste, J.: Bunyavirus membrane glycoproteins as models for Golgi-specific proteins. In Satir, B. (ed.), Modern Cell Biology, pp. 65-96 (Alan R. Liss, New York, 1988).

Schmaljohn, C.S.; Dalrymple, J.M.: Analysis of Hantaan virus RNA: Evidence for a new genus of Bunyaviridae. Virology 131:482-491 (1983).

Schmaljohn, C.S.; Patterson, J.L.: Bunyaviridae and their replication, Part II. Replication of Bunyaviridae; In Fields, B.N.; Knight, J.C. (eds.), Virology, Vol.1, 2nd edn., pp. 11751194 (Raven Press, New York, 1990).

Simons, J.F.; Hellmann, U.; Pettersson, R.F.: Uukuniemi virus S RNA segment: ambisense coding strategy, packaging of complementary strands into virions, and homology to members of the genus Phlebovirus. J. Virol. 64: 247-255 (1990).

Tesh, R.B.; Peters, C.J.; Meegan, J.M.: Studies on the antigenic relationship among phleboviruses. Am. J. Trop. Med. Hyg. 31: 149-155 (1982).

Ward, V.K.; Marriott, A.C.; El-Ghorr, A.A.; Nuttall, P.A.: Coding strategy of the S RNA segment of Dugbe virus (Nairovirus; Bunyaviridae). Virology 175: 518-524 (1990).

Zeller, H.G.; Karabatsos, N.; Calisher, C.H.; Digoutte, J.P.; Cropp, C.B.; Murphy, F.A.; Shope, R.E.: Electron microscopic and antigenic studies of uncharacterized viruses. II. Evidence suggesting the placement of viruses in the family Bunyaviridae. Arch. Virol. 108: 211-227 (1989). 


\begin{tabular}{|lll}
\hline FAMILY & ARENAVIRUS GROUP & ARENAVIRIDAE \\
\hline
\end{tabular}

Reported by M.J. Buchmeier

\begin{tabular}{llc}
\hline \hline GENUS & LCM VIRUS GROUP & ARENAVIRUS \\
\hline TYPE SPECIES & LYMPHOCYTIC & - \\
& CHORIOMENINGITIS & \\
& VIRUS (LCM) & \\
\hline
\end{tabular}

\section{Properties of The Virus Particle}

Morphology

Enveloped, spherical to pleomorphic particles, $50-300 \mathrm{~nm}$ diameter (usually $110-130 \mathrm{~nm}$ ). The dense lipid bilayer envelope has surface projections $10 \mathrm{~nm}$ long and clubshaped. Varying numbers of ribosome-like particles (20$25 \mathrm{~nm}$ diameter) appear free within the envelope. Isolated nucleocapsids, free of contaminating host ribosomes, display a linear array of nucleosomal subunits organized in closed circles varying in length from 450-1300 nm.

Physicochemical properties

\section{Nucleic acid}

$\mathrm{S}_{20 \mathrm{w}}=325-500$; buoyant density in sucrose $=1.17-1.18$ $\mathrm{g} / \mathrm{cm}^{3}$; in $\mathrm{CsCl}=1.19-1.20 \mathrm{~g} / \mathrm{cm}^{3}$; in amidotrizoate compounds $\approx 1.14 \mathrm{~g} / \mathrm{cm}^{3}$. Relatively unstable in vitro. Rapidly inactivated below pH 5.5 and above pH 8.5. Inactivated rapidly at $56^{\circ} \mathrm{C}$ and by solvents. Highly sensitive to $\mathrm{UV}$ and gamma radiation.

Two virus specific ssRNA molecules, $\mathrm{L}$ and $\mathrm{S}$ (MWs $=$ $2.2-2.8 \times 10^{6}$ and $\approx 1.1 \times 10^{6}$ ), and three RNAs of cell origin, $\approx 28 \mathrm{~S}, 18 \mathrm{~S}$ and $4-6 \mathrm{~S}$. The 4-6S RNA also contains a subgenomic viral mRNA encoding the $Z$ gene. Proportions of $S$ to $L$ RNA are not equimolar due to frequent packaging of multiple S RNA strands.

The S RNAs of Pichinde, LCM, Lassa and Tacaribe viruses have been sequenced and consist of 3375-3432 nucleotides. These RNAs are similarly organized and share considerable sequence homology. A 3 ' region (1930 nucleotides) of conserved sequences is shared by the different viruses and is complementary to a similar region found at the 5 ' end. Similar regions are found at the termini of the L RNAs. Two genes encoded in an ambisense are associated with S RNA. The gene encoding the nucleoprotein is found in the $3^{\prime}$ half of the molecule (in message complementary sense) while the gene for the glycoproteins is encoded (in message sense) in the 5' half. The intergenic regions contain nucleotide sequences with 
the potential of forming hairpin configurations which may regulate transcription.

The L RNAs of LCM and Tacaribe viruses have also been sequenced and contain 7220 and 7102 nucleotides, respectively. Viral L RNA encodes a large protein (L) which may function as an RNA dependent, RNA polymerase and a small protein $(\mathrm{p} 11, \mathrm{Z})$, which has a zincbinding domain. The L RNA genes also have an ambiense arrangement with the $L$ protein encoded on the $3^{\prime}$ end (in message complementary sense) and the $\mathrm{Z}$ protein encoded (in message sense) on the $5^{\prime}$ portion (ca. $0.5 \mathrm{~kb}$ ) of the $\mathrm{L}$ RNA segment.

Protein

\section{Lipid}

Carbohydrate

\author{
Antigenic \\ properties
}

One nonglycosylated polypeptide $\left(\mathrm{MW}=63-72 \times 10^{3}\right)$ associated with the RNA as part of RNP complex. One glycosylated polypeptide with $\mathrm{MW}=34-44 \times 10^{3}$ found in all members of the family and a second glycosylated polypeptide of $\mathrm{MW}=44-72 \times 10^{3}$ noted in some but not other members. These envelope glycoproteins are synthesized in the cell as a single mannose-rich precursor molecule which is trimmed and proteolytically cleaved during transport to the plasma membrane. L protein, (MW $\approx 2 \times 10^{5}$ ) has been identified in virions as well as infected cells is an RNA-dependent RNA polymerase. Other minor proteins of unknown significance have also been detected. Enzymes found in purified virions include the transcriptase associated with the RNP of Pichinde virus, poly(U) and poly(A) polymerases which appear to be associated with the packaged host cell ribosomes and a protein kinase capable of phosphorylating the nucleoprotein.

Present; phospliolipid composition is similar to that of the host cell plasma membrane.

Glucosamine, fucose and galactose are incorporated into numerous asparagine-linked branched chain complex carbohydrates of the viral glycoproteins.

At least 3 distinct antigenic molecules. Antigens on the surface glycoprotein $\left(\mathrm{MW}=34-44 \times 10^{3}\right)$ are involved in virus neutralization. These antigens are type-specific although cross-neutralization tests have demonstrated partial shared antigenicity between Tacaribe and Junin viruses, and cross-protection between Junin and Lassa viruses following prior infection by Tacaribe and Mopeia viruses has been demonstrated. CF antigens are used to define the Tacaribe complex. Major CF antigens are associated with the nucleoprotein. Monoclonal antibodies react with common epitopes on nucleocapsid proteins of all 
members. Fluorescent antibody techniques show that antisera against all Tacaribe complex viruses, as well as Lassa virus, react with LCM virus. No haemagglutinin has been identified. By monoclonal and polyclonal antibodies, LCM-Lassa complex viruses are distinguishable from Tacaribe complex viruses. Cytotoxic T-lympocyte epitopes are well characterized on the nucleoprotein and glycoprotein of LCM virus. Number and location of epitopes vary depending on virus strain and host MHC class molecules.

\section{REPLICATION}

Limited data support the concept of differential transcription of the ambisense S RNA segment. Early events post infection include the synthesis of mRNA for the nucleoprotein which is required for the synthesis of complementary S RNA and progeny RNA. Messenger RNA for glycoprotein precursor is synthesized from the complementary RNA. Infected cells synthesise a protein $\left(\mathrm{MW} \approx 64 \times 10^{3}\right)$ to yield RNP, and two other proteins (MW $\approx 42 \times 10^{3}$ and $200 \times 10^{3}$ ), the smaller giving rise to a fully glycosylated precursor $\left(\mathrm{MW}=79 \times 10^{3}\right)$ which in turn is cleaved to yield the envelope glycoproteins. Highfrequency genetic recombination is found as expected for viruses with segmented genomes. Reassortment studies of LCM suggest that genetic information in L RNA controls plaque morphology and virulence in guinea pigs while tissue tropism and virulence in mice are associated with $S$ RNA. The synthesis of LCM DI virus has been observed in vivo as well as in vitro. DNA synthesis inhibitors have no effect on arenavirus multiplication, but a functional host-cell nucleus is required. Replication in vitro of a number of arenaviruses is inhibited by amantadine, $\alpha$ amanitin, benzimidazoles, glucosamine, and thiosemicarbazones. Ribavirin appears to inhibit the replication of several arenaviruses in vitro and spares monkeys infected with Machupo and Lassa viruses.

Most, if not all, arenaviruses probably have limited cell killing potential. However, virus replication commonly occurs in the absence of overt cytopathic effects and carrier cultures are readily established in tissue culture. DI particles are readily produced and interference may play a role in preventing cell destruction.

Intracytoplasmic inclusion bodies are prominent in cells infected with arenaviruses; they consist of ribosome masses in a moderately electron-dense matrix. The relative 
proportion of ribosomes and matrix may vary widely in different inclusions, but as infection progresses a condensation of inclusion material results in rather uniformly marginated, large masses.

\section{Biological ASPECTS}

Host range

Natural: Virus isolates from the Old World appear to be restricted to the family Muridae and those from the New World to the family Cricetidae with the two exceptions of Amapari virus which was isolated from a Muridae (Neacomys) and TAC virus which was isolated from a fruit-eating bat (Artibeus). Most viruses are found as a chronic infection in a single rodent host (Mus, Calomys, Mastomys, Oryzomys, Sigmodon, Praomys, and the fruiteating bat Artibeus) in which persistent infection with viremia and/or viruria occur or are suspected. Such infections may be caused by a slow and/or insufficient immune response of the host. Natural spread to other mammals and humans is unusual except for Lassa virus, a common infection of humans in West Africa, and Junin virus, a less common but significant infection of humans in Argentina. LCMV infection of humans has been significant in some urban areas with high rodent populations. It has also been reported to be acquired from pet hamsters. Disease outcome in experimentally infected laboratory animals (mouse, hamster, guinea pig, rhesus monkey, marmoset, rat) vary with the type of virus used. In general, viruses of the Tacaribe complex are pathogenic for suckling but not weaned mice; LCM and Lassa viruses produce the opposite effect. Cross-protection is seen against Junin and Lassa with prior infection by Tacaribe and Mozambique viruses, respectively. LCM virus has been found to grow in murine lymphocytes. Vero and BHK21 infected cells are most commonly used for virus isolation and growth, but the viruses grow moderately well in many other mammalian cells.

Transmission Vertical - transuterine, transovarian and postpartum (most likely by milk-, saliva- or urine-borne routes) in natural hosts. Horizontal - important as a mechanism for viruses to escape from their natural host. Venereal transmission suspected as an important mode for intra-species spread. Vectors - a few arthropod isolations which have never been shown to have any place in transmission cycles in nature. Biological - unknown. Mechanical - unknown. 


\section{OTHER MEMBERS}

LCM-Lassa Complex:

\begin{tabular}{cl} 
& \multicolumn{1}{c}{ Lymphocytic choriomeningitis (LCM) } \\
& Lassa \\
& Mobala \\
Mopeia & \\
& Ippy \\
& Tacaribe \\
& Junin \\
Tacaribe Complex: & Macupo \\
& Amapari \\
& Parana \\
& Tamiami \\
& Pichinde \\
& Latino \\
& Flexal
\end{tabular}

Derivation of Name arena: from Latin arenosus, 'sandy', from appearance of particles in electron microscope sections.

\section{REFERENCES}

Auperin, D.D.; Romanowski, V.; Galinski, M.; Bishop, D.H.L.: Sequencing studies of Pichinde arenavirus S RNA indicate a novel coding strategy, an ambisense viral S RNA. J. Virol. 52:897-904 (1984).

Auperin, D.D.; Sasso, D.R.; McCormick, J.B.: Nucleotide sequence of the glycoprotein gene and intergenic region of the Lassa virus $S$ genome RNA. Virology 154:155-167 (1986).

Bruns, M.; Cihak, J.; Muller, G.; Lehmann-Grube, F.: Lymphocytic choriomeningitis virus. VI. Isolation of a glycoprotein mediating neutralization. Virology 130:247-251 (1983).

Buchmeier, M.J.; Southern, P.J.; Parekh, B.S.; Wooddell, M.K.; Oldstone, M.B.A.: Sitespecific antibodies define a cleavage site conserved among Arenavirus GP-C glycoproteins. J. Virol. 61:982-985 (1987).

Casals, J.; Buckley, S.M.; Cedeno, R.: Antigenic properties of the arenaviruses. Bull WHO 52: 421-427 (1975).

Franze-Fernandez, M.T.; Zetina, C.; Iapalucci, S.; Lucero, M.A.; Bouissou, C.; Lopez, R.; Rey, O.; Daheli, M.; Cohen, G.N.; Zakin, M.M.: Molecular structure and early events in the replication of Tacaribe arenavirus S RNA. Virus Res. 7:309-324 (1987).

Fuller-Pace, F.V.; Southern, P.J.: Detection of virus-specific RNA-dependent RNA polymerase activity in extracts from cells infected with lymphocytic choriomeningitis virus: In vitro synthesis of full-length viral RNA species. J. Virol. 63: 1938-1944 (1989).

Gonzalez, J.P.: Les arenavirus D'Afrique: un nouveau paradigme d'evolution. Bull. Inst. Pasteur 84:67-85 (1986).

Harnish, D.G.; Dimock, K.; Bishop, D.H.L; Rawls, W.E.: Gene mapping in Pichinde virus: assignment of viral polypeptides to genomic L and S RNAs. J. Virol. 46:638-641 (1983).

Howard, C.R.: Arenaviruses, In Perspectives in Medical Virology, Vol. 2 (Elsevier, New York, 1986). 
Howard, C.R.; Buchmeier, M.J.: A protein kinase activity in lymphocytic choriomeningitis virus and identification of the phosphorylated product using monoclonal antibody. Virology 126:538-547 (1983).

Iapalucci, S.; Lopez, N.; Rey, O.; Zakin, M.M.; Cohen, G.N.; Franze-Fernandez, M.T.: The 5' region of Tacaribe virus $L$ RNA encodes a protein with a potential metal binding domain. Virology 173: 357-361 (1989).

Iapalucci, S.; Lopez, R.; Rey, O.; Lopez, N.; Franze-Fernandez, M.T.; Cohen, G.N.; Lucero, M.A.; Ochoa, A.; Zakin, M.M.: Tacaribe virus L gene encodes a protein of 2210 amino acid residues. Virology 170: 40-47 (1989).

Parekh, B.S.; Buchmeier, M.J.: Proteins of lymphocytic choriomeningitis virus: Antigenic topography of the viral glycoproteins. Virology 153:168-178 (1986).

Romanowski, V.; Matsuura, Y.; Bishop, D.H.L.: Complete sequence of the S RNA of lymphocytic choriomeningitis virus (WE strain) compared to that of Pichinde arenavirus. Virus Res. 3:101-114 (1985).

Rowe, W.P.; Murphy, F.A.; Bergold, G.H.; Casals, J.; Hotchin, J.; Johnson, K.M.; LehmannGrube, F.; Mims, C.A.; Traub, E.; Webb, P.A.: Arenoviruses: proposed name for a newly defined virus group. J. Virol. 5: 651-652 (1970).

Southern, P.J.; Singh, M.K.; Riviere, Y.; Jacoby, D.R.; Buchmeier, M.J.; Oldstone, M.B.A.: Molecular characterization of the genomic S RNA segment from lymphocytic choriomeningitis virus. Virology 157:145-155 (1987).

Young, P.R.; Howard, C.R.: Fine structure analysis of Pichinde virus nucleocapsids. J. gen. Virol. 64:833-842 (1983). 


\begin{tabular}{|lll|}
\hline FAMILY & $\begin{array}{l}\text { RNA TUMOR VIRUSES } \\
\text { (AND RELATED AGENTS) }\end{array}$ & RETROVIRIDAE \\
\hline
\end{tabular}

Reported by J.M. Coffin

Morphology

\section{Properties of the Virus Particle}

Morphology

Physicochemical properties

Nucleic acid

Protein

Lipid

Carbohydrate
Spherical, enveloped virions $80-100 \mathrm{~nm}$ in diameter. Glycoprotein surface projections of approximately $8 \mathrm{~nm}$ diameter. Internal structure: spherical to rod-shaped capsid containing a possibly helical RNP. Special features in thin sections: outer envelope, inner membrane (shell) and central nucleoid. The central nucleoid is located acentrically in type B virions, concentrically in type C virions, and is in the shape of a rod or truncated cone in lentiviruses.

Density between 1.16 and $1.18 \mathrm{~g} / \mathrm{cm}^{3}$ in sucrose gradients. Disrupted by lipid solvents and detergents. Surface glycoproteins partially removable by proteolytic enzymes. Relatively resistant to UV light.

Dimer of linear positive-sense ssRNA 7-10 kbp in length (about $2 \%$ by weight). Monomers held together by hydrogen bonds. Polyadenylated at the 3 ' end, with a cap structure $\left(\mathrm{m}^{7} \mathrm{G}^{5} \mathrm{ppp}^{5} \mathrm{GmpNp}\right)$ at the $5^{\prime}$ end of the genome. The virion RNA is not infectious.

About $60 \%$ by weight. Three to four internal nonglycosylated structural proteins (encoded by the $g a g$ gene): MA (matrix); CA (capsid); and NC (nucleocapsid); and (in some genera) one more protein of undetermined function. The MA protein is often acylated with a fatty acid (e.g. myristate) group at its $\mathrm{NH}_{2}$-terminus. A protease (PR) is encoded by the pro gene. Reverse transcriptase (RT) and integrase (IN) encoded by the pol gene. Two envelope (env gene encoded) proteins SU (surface) and TM (transmembrane).

About $35 \%$ by weight. Derived from the plasma membrane of the host cell.

About $3.5 \%$ by weight. At least one of the two env proteins (SU) is glycosylated; in most viruses both are. Cellular carbohydrates and glycolipids are found in the viral envelope. 
Taxonomic status

Antigenic properties

Genetic structure
English vernacular name

International name

Virion proteins contain type-specific and group-specific determinants, the latter sometimes shared among members of a genus. The type-specific determinants of the envelope glycoproteins are involved in antibody neutralization.

Although virions carry two copies of the genome, it is not known whether both are functional. Basic genetic information for the production of infectious progeny virus consists of 4 genes: gag, coding for internal structural proteins of the virion; pro, encoding the virion protease; pol, coding for reverse transcriptase; and env, coding for envelope glycoproteins of the virion. The order of these genes is invariably 5' gag, pro, pol, env 3'. Some retroviruses also contain genes encoding non virion proteins which are important for the regulation of expression. Others carry cell-derived genetic information for nonstructural proteins that are important in pathogenesis. These cellular sequences are either inserted in a complete retrovirus genome (some strains of Rous sarcoma virus) or they form substitutions for deleted viral replicative sequences (most other rapidly oncogenic retroviruses). Such deletions render the virus replicationdefective and dependent on nontransforming helper virus for production of infectious progeny. In many cases the cell-derived sequences form a fused gene with viral structural information that is then translated into one protein (e.g., 'gag-onc' protein).

\section{REPLICATION}

Entry into the host cell is mediated by interaction between an envelope glycoprotein of the virion and specific receptors at the cell surface, possibly resulting in fusion of the viral envelope to the plasma membrane either directly or following endocytosis. Receptors are cell surface proteins of which two have been identified to date: one (the CD4 protein recognized by HIV) has a single transmembrane region; the other (the receptor for ecotropic MLV) has a more complex structure with multiple transmembrane domains. The further process of intracellular uncoating of the viral particle is not understood, but subsequent early events are carried out in the context of a nucleoprotein complex derived from the capsid. Replication starts with reverse transcription of virion RNA into DNA. The linear dsDNA transcripts of the viral genome contain long terminal repeats (LTR's) composed of sequences from the 3' (U3) and 5' (U5) ends of the viral RNA flanking a sequence $(\mathrm{R})$ found near both ends of the viral RNA. Retroviral DNA becomes 
integrated into the chromosomal DNA of the host to form a provirus by a mechanism involving the viral IN protein. The ends of virus DNA are joined to cell DNA, removing one or two bases from the ends of the linear viral DNA and generating a short duplication of cell sequences at the integration site. Viral DNA can integrate at many sites in the cellular genome, and once integrated is apparently incapable of further "transposition" within the same cell. The map of the integrated provirus is coextensive with that of unintegrated linear viral DNA. Integration appears to be a prerequisite of virus replication. The integrated provirus is transcribed by cellular RNA polymerase II into virion RNA and mRNA in response to transcriptional signals in the LTR's. There are several classes of mRNA reflecting the genetic map of retroviruses. An mRNA comprising the whole genome serves for the translation of the gag, pro, and pol genes positioned at the 5' portion of this RNA into polyprotein precursors which are cleaved by the PR protein to yield the structural proteins, protease and reverse transcriptase, respectively. A smaller mRNA consisting of the 3 ' sequences of the genome, including the env gene and the $\mathrm{U} 3$ and $\mathrm{R}$ regions, is translated into the precursor of the envelope proteins. In viruses that contain additional genes, other forms of spliced mRNA are also found. All mRNAs share a common sequence at their $5^{\prime}$ ends. In the less-than-genome size mRNAs this sequence is acquired by RNA splicing. Most primary translational products in retrovirus infection are polyproteins which require proteolytic cleavage before becoming functional. The gag, pro and pol products are produced from a nested set of primary products whose translation is mediated by partial readthrough of translational terminal signals (usually by ribosomal frame shifting) at the gag-pro and/or the pro-pol boundaries. Virions mature either at the plasma membrane (type $\mathrm{C}$ and most other viruses) or as intracytoplasmic (type A) particles and are released from the cell by a budding process.

\section{Biological ASPECTS}

Host range

Retroviruses are widely distributed as exogenous infectious agents of vertebrates, particularly mammals and birds. Endogenous proviruses that have resulted from infection of the germ line and are inherited as Mendelian genes occur widely among vertebrates.

Association with disease

Retroviruses are associated with a large variety of diseases, including malignancies (leukemias, lymphomas, sarcomas and other tumors of mesodermal origin, mammary carcinomas, carcinomas of liver and kidney); 
Transmission Transmission is horizontal via a number of routes, including blood, saliva, intimate contact, insects, and others and vertical via direct infection of the developing embryo, via milk, or other perinatal routes. Endogenous retroviruses are also transmitted by inheritance of proviruses.

\section{GENERA}

In view of current knowledge of retroviruses, the "previous" classification into subfamilies (oncovirinae, lentivirinae, spumavirinae) is no longer appropriate, since the genera that made up, for example, oncovirinae are no more closely related (or similar) to one another than they are to members of other previously designed subfamilies. Retroviruses are currently classified into 7 genera as follows:

Mammalian type B oncovirus group

MLV-related viruses

(Mammalian type $\mathrm{C}$ retrovirus group)

Type $\mathrm{D}$ retrovirus group

Avian type $\mathrm{C}$ retrovirus group

(ALV-related viruses)

Foamy virus group

Spumavirus

HTLV-BLV group

Lentivirus group

Lentivirus

\begin{tabular}{lll}
\hline \hline GENUS & MAMMALIAN TYPE B & - \\
& ONCOVIRUS GROUP & - \\
\hline TYPE SPECIES & $\begin{array}{l}\text { MOUSE MAMMARY } \\
\text { TUMOR VIRUSES }\end{array}$ & - \\
\hline
\end{tabular}

\section{DISTINGUISHING CHARACTERISTICS}

Virion: B-type morphology (prominent surface spikes, eccentric condensed core, assembly occurs within the cytoplasm as A-type particles prior to budding). Proteins: $\mathrm{MA} \approx 10 \mathrm{kDa} ; \mathrm{p} 21 ; \mathrm{CA} \approx 27 \mathrm{kDa} ; \mathrm{NC} \approx 14 \mathrm{kDa} ; \mathrm{PR} \approx 13$ $\mathrm{kDa} ; \mathrm{SU} \approx 52 \mathrm{kDa} ; \mathrm{TM} \approx 36 \mathrm{kDa}$.

Genome: $\approx 10 \mathrm{~kb}$. One additional gene (orf- function unknown) 3' of gag-pro-pol and env. Primer tRNALys-3. LTR $\approx 1300$ bp. (U3 1200, R 15, U5 120). 
Distribution: Limited to a few exogenous, verticallytransmitted (via milk) and endogenous viruses of mice. Associated with mammary carcinoma and T-lymphoma. Related endogenous sequences have been found in other rodents and primates. No oncogene-containing members are known.

\begin{tabular}{lll}
\hline \hline GENUS & $\begin{array}{l}\text { MLV-RELATED VIRUSES } \\
\text { (MAMMALIAN TYPE C }\end{array}$ & - \\
& RETROVIRUS GROUP) & \\
\hline TYPE SPECIES & MURINE LEUKEMIA VIRUS & - \\
\hline
\end{tabular}

\section{DISTINGUISHING CHARACTERISTICS}

Virion: C-type morphology (barely visible surface spikes, central condensed core, assembly occurs at the inner surface of the membrane at the same time as budding). Proteins: $\mathrm{MA} \approx 15 \mathrm{kDa} ; \mathrm{p} 12 ; \mathrm{CA} \approx 30 \mathrm{kDa} ; \mathrm{NC} \approx 10 \mathrm{kDa}$; $\mathrm{PR} \approx 14 \mathrm{kDa} ; \mathrm{SU} \approx 70 \mathrm{kDa} ; \mathrm{TM} \approx 15 \mathrm{kDa}$.

Genome: $\approx 8.3 \mathrm{~kb}$. No known additional genes to $g a g$ pro-pol and env. Primer tRNA Pro (tRNA Glu is found in a few endogenous mouse viruses). LTR $\approx 600 \mathrm{bp}$. (U3 500, R 60 , U5 75).

Distribution: Widespread exogenous vertically and horizontally transmitted and endogenous viruses found in many groups of mammals. The reticuloendotheliosis group comprises a few isolates from birds, with no known corresponding endogenous relatives. Related endogenous sequences are found in mammals. Associated with a variety of diseases including malignancies, immunosuppression, neurological disorders and others. Many oncogene-containing members of the mammalian and reticuloendotheliosis virus groups have been isolated.

\section{SUBGENERA}

Mammalian type $\mathrm{C}$ viruses

species: Murine sarcoma and leukemia viruses Feline sarcoma and leukemia viruses Gibbon ape leukemia virus Guinea pig type $\mathrm{C}$ virus Porcine type $\mathrm{C}$ virus Woolly monkey sarcoma virus

Reticuloendotheliosis viruses 
species: Avian reticuloendotheliosis virus

Reptilian type $\mathrm{C}$ viruses

species: $\quad$ Viper retrovirus

\begin{tabular}{lll}
\hline \hline GENUS & TYPE D RETROVIRUS GROUP & - \\
\hline TYPE SPECIES & MASON-PFIZER MONKEY VIRUS & - \\
\hline
\end{tabular}

\section{DISTINGUISHING CHARACTERISTICS}

Virion: D-type morphology (resembling B-type except for less prominent surface spikes). Proteins: $\mathrm{MA} \approx 10 \mathrm{kDa}$; $\mathrm{p} 18 ; \mathrm{CA} \approx 27 \mathrm{kDa} ; \mathrm{NC} \approx 14 \mathrm{kDa} ; \mathrm{PR}$ unknown; $\mathrm{SU} \approx 70$ $\mathrm{kDa} ; \mathrm{TM} \approx 22 \mathrm{kDa}$.

Genome: $\approx 8.0 \mathrm{~kb}$. No known additional genes to gagpro-pol and env. Primer tRNALys 1,2 . LTR $\approx 350 \mathrm{bp}$. (U3 240, R 15, U5 95).

Distribution: Several isolates of exogenous, horizontally transmitted and endogenous viruses of new and old world primate species. Exogenous virus isolates associated with immunodeficiency diseases. No oncogene-containing members are known.

\section{OTHER MEMBERS}

Squirrel monkey retrovirus

Langur virus (PO-1-Lu)

\begin{tabular}{lll}
\hline \hline GENUS & AVIAN TYPE C & - \\
& $\begin{array}{l}\text { RETROVIRUS GROUP } \\
\text { (ALV-RELATED VIRUSES) }\end{array}$ & \\
\hline TYPE SPECIES & AVIAN LEUKOSIS VIRUS & - \\
\hline
\end{tabular}

\section{DISTINGUISHING CHARACTERISTICS}

Virion: C-type morphology. Proteins: $\mathrm{MA} \approx 19 \mathrm{kDa}$; 10 ; $\mathrm{CA} \approx 27 \mathrm{kDa} ; \mathrm{NC} \approx 12 \mathrm{kDa} ; \mathrm{PR} \approx 15 \mathrm{kDa} ; \mathrm{SU} \approx 85 \mathrm{kDa}$; $\mathrm{TM} \approx 37 \mathrm{kDa}$.

Genome: $\approx 7.2 \mathrm{~kb}$. No known additional genes to gagpro-pol and env. Primer tRNATrp. LTR $\approx 350 \mathrm{bp}$. (U3 250, R 20, U5 80).

Distribution: Widespread exogenous vertically and horizontally transmitted and endogenous viruses found in 
chickens and some other birds. Distantly related endogenous sequences are found in birds and mammals. Associated with malignancies and some other diseases such as wasting, osteopetrosis. Many oncogenecontaining members of this group have been isolated.

\section{OTHER MEMBERS}

Avian sarcoma and leukemia viruses

\begin{tabular}{llc}
\hline \hline GENUS & FOAMY VIRUS GROUP & SPUMAVIRUS \\
\hline TYPE SPECIES & HUMAN FOAMY VIRUS & - \\
\hline
\end{tabular}

\section{DISTINGUISHING CHARACTERISTICS}

Virion: Distinctive (but unnamed) morphology (prominent surface spikes, central condensed core, assembly occurs in the cytoplasm prior to budding). Proteins are not yet well defined.

Genome: $\approx 11 \mathrm{~kb}$. Several additional open reading frames (tentatively designated "bel 1,2,3,4" of unknown coding capacity and function) 3 ' to gag-pro-pol and env. Primer tRNA ${ }^{\text {Lys } 1,2}$. LTR $\approx 1150$ bp. (U3 800, R 200, U5 150).

Distribution: Widespread exogenous viruses found in many groups of mammals. No related endogenous viruses are known. Although many isolates cause characteristic "foamy". cytopathology in cell culture, no associated diseases have been described. No oncogene-containing members of this group have been isolated.

\section{OTHER MEMBERS}

Simian foamy virus

Feline syncytial virus

Bovine syncytial virus 


\begin{tabular}{lll}
\hline \hline GENUS & HTLV-BLV GROUP & - \\
\hline TYPE SPECIES & $\begin{array}{l}\text { HUMAN T-CELL LYMPHOTROPIC } \\
\text { VIRUS TYPE 1 }\end{array}$ & - \\
\hline
\end{tabular}

\section{DISTINGUISHING CHARACTERISTICS}

Virion: Similar to C-type in morphology and assembly. Proteins: $\mathrm{MA} \approx 19 \mathrm{kDa} ; \mathrm{CA} \approx 24 \mathrm{kDa} ; \mathrm{NC} \approx 12,15 \mathrm{kDa}$; $\mathrm{PR} \approx 14 \mathrm{kDa} ; \mathrm{SU} \approx 60 \mathrm{kDa} ; \mathrm{TM} \approx 21 \mathrm{kDa}$.

Genome: $\approx 8.3 \mathrm{~kb}$. Two additional genes (tax and rex) whose products are involved in regulation of synthesis and processing of virus RNA 3' to gag-pro-pol and env. Primer tRNAPro. LTR $\approx 550-750$ bp. (U3 200-300, R 135-235, U5 100-200).

Distribution: Exogenous horizontally-transmitted viruses found in a few groups of mammals. No related endogenous viruses are known. Associated with B or adult $\mathrm{T}$ cell leukemia/lymphoma with a very long latency and less than $100 \%$ incidence. No oncogene-containing members of this group have been isolated.

\section{OTHER MEMBERS}

Human T-cell lymphotropic virus type 2

Simian T-cell lymphotropic virus

Bovine leukemia virus

\begin{tabular}{llc}
\hline \hline GENUS & LENTIVIRUS GROUP & LENTIVIRUS \\
\hline TYPE SPECIES & HUMAN IMMUNO- & - \\
& DEFICIENCY VIRUS & \\
\hline
\end{tabular}

\section{DISTINGUISHING CHARACTERISTICS}

Virion: Distinctive (but unnamed) morphology with a bar (or truncated cone)-shaped core. Assembly at the cell membrane. Proteins: $\mathrm{MA} \approx 17 \mathrm{kDa} ; \mathrm{CA} \approx 24 \mathrm{kDa} ; \mathrm{NC} \approx$ $7-11 \mathrm{kDa} ; \mathrm{PR} \approx 14 \mathrm{kDa} ; \mathrm{SU} \approx 120 \mathrm{kDa} ; \mathrm{TM} \approx 41 \mathrm{kDa}$.

Genome: $\approx 9.2 \mathrm{~kb}$. Several additional genes varying somewhat among the groups (e.g. vif, vpr, tat, rev, vpu in HIV-1) whose products are involved in regulation of synthesis and processing of virus RNA and possibly other functions, located 3' to gag-pro-pol and 5' to env, as well as one (nef in HIV) 3' of env. Primer tRNA ${ }^{\text {Lys } 1,2}$. LTR $\approx 600$ bp. (U3 450, R 100, U5 70). 
Distribution: Exogenous horizontally and verticallytransmitted viruses found in humans and many other groups of mammals. No related endogenous viruses are known. Associated with a variety of diseases including immunodeficiencies, neurological disorders, arthritis, and others. No oncogene-containing members of this group have been isolated.

\section{OTHER MEMBERS}

\section{SUBGENERA}

Primate immunodeficiency viruses

species: Human immunodeficiency virus type 1 Human immunodeficiency virus type 2 Simian immunodeficiency virus

Ovine/caprine lentiviruses

species: Visna/Maedi virus Caprine arthritis/encephalitis virus

Equine lentiviruses

species: Equine infectious anemia virus

Feline lentiviruses

species: Feline immunodeficiency virus

Bovine lentiviruses

species: Bovine imunodeficiency virus

Derivation of Name retro: from Latin 'backwards' (refers also to reverse transcriptase)

onco: from Greek onkos, 'tumor'. spuma: from Latin 'foam'.

lenti: from Latin 'slow' 


\section{REFERENCES}

Coffin, J.M.: Retroviridae and their replication. In Fields, B.N.; Knight, J.C. (eds.), Virology, Vol. 2, 2nd edn., pp. 1437-1500 (Raven Press, New York, 1990).

Doolittle, R.F.; Feng, D.-F.; Johnson, M.S.; McClure, M.A.: Origins and evolutionary relationships of retroviruses. Quart. Rev. Biol. 64: 1-30 (1989).

Gallo, R.; Wong-Staal, F.; Montagnier, L.; Haseltine, W.A.; Yoshida, M.: HIV/HTLV gene nomenclature. Nature 333: 504 (1988).

Leis, J.; Baltimore, D.; Bishop, J.M.; Coffin, J.; Fleissner, E.; Goff, S.P.; Oroszlan, S.; Robinson, H.; Skalka, A.M.; Temin, H.M.; Vogt, V.: Standardized and simplified nomenclature for proteins common to all retroviruses. J. Virol. 62: 1808-1809 (1988).

Maurer, B.; Bannert, H.; Darai, G.; Flugel, R.M.: Analysis of the primary structure of the long terminal repeat and the gag and pol genes of the human spumaretrovirus. J. Virol. 62: 1590-1597 (1988).

Myers, G.; Rabson, A.B.; Josephs, S.F.; Smith, T.F.; Berzofsky, J.A.; Wong-Staal, F.: Human retroviruses and AIDS 1990. (Los Alamos National Laboratory, Los Alamos, New Mexico, 1990).

Varmus, H.; Brown, P.: Retroviruses. In Berg, D.E.; Howe, M.M. (eds.), Mobile DNA, pp. 53-108. (ASM, Washington, 1989).

Weiss, R.; Teich, N.; Varmus, H.; Coffin, J.: RNA tumor viruses, 1/ Text. (Cold Spring Harbor, New York, 1984).

Weiss, R.; Teich, N.; Varmus, H.; Coffin, J.: RNA tumor viruses, 2/ Supplements and appendices. (Cold Spring Harbor, New York, 1985). 


\begin{tabular}{|lll}
\hline FAMILY CALICIVIRUS FAMILY CALICIVIRIDAE \\
\hline
\end{tabular}

Compiled by F.L. Schaffer

\begin{tabular}{llc}
\hline \hline GENUS & CALICIVIRUS GROUP & CALICIVIRUS \\
\hline TYPES SPECIES & VESICULAR EXANTHEMA & - \\
& OF SWINE VIRUS & \\
& (VESV) (SEROTYPE A) & \\
\hline
\end{tabular}

\section{Properties of the Virus Particle}

Morphology Roughly spherical, 35-39 nm diameter, with 32 cupshaped surface depressions arranged in icosahedral symmetry. Capsid probably consists of 180 polypeptides.

Physicochemical $\mathrm{MW} \approx 15 \times 10^{6} ; \mathrm{S}_{20 \mathrm{w}}=170-183$; buoyant density in properties $\mathrm{CsCl}=1.33-1.39 \mathrm{~g} / \mathrm{cm}^{3}$ depending upon virus and strain. Insensitive to ether, chlorolform or mild detergents. Inactivated at $\mathrm{pH}$ values between 3 and 5 . Thermal inactivation is accelerated in high concentrations of $\mathrm{Mg}^{++}$. Some members inactivated by trypsin.

Nucleic acid

One molecule of infectious positive-sense ssRNA, MW = $2.6-2.8 \times 10^{6}(\approx 8.2 \mathrm{~kb})$. Polyadenylated at 3'-terminus: no methylated cap at 5 '-terminus.

Protein

Lipid

Carbohydrate

Antigenic properties

Effect on cells Lysis.

None.
One major capsid polypeptide, $\mathrm{MW}=60-71 \times 10^{3}$ with blocked $\mathrm{N}$-terminal end. A protein with apparent $\mathrm{MW}=$ $10-15 \times 10^{3}$, essential for infectivity, is covalently linked to virion RNA, presumably a Vpg at the 5'-end. A minor polypeptide, $\mathrm{MW}=15-19 \times 10^{3}$ and $<2 \%$ of total protein possibly noncovalently associated with RNA, has also been reported.

None reported.

Neutralization indicates distinct serotypes of vesicular exanthema of swine and San Miguel sealion viruses, but considerable cross-reactivity among feline calicivirus strains. Precipitin reactions indicate antigenic relationships among swine vesicular exanthema, San Miguel sealion and feline caliciviruses but no relationship of these to canine calicivirus. 


\section{REPLICATION}

Two major virus-specific ssRNA species in infected cells are a genome-sized RNA and a smaller RNA $(\approx 2.4 \mathrm{~kb}$ for feline calicivirus, apparent size may differ depending on virus and method of analysis). Genome-sized RNA presumably serves as mRNA coding for non-structural polypeptides, and the smaller RNA is presumably a subgenomic mRNA coding for the major capsid polypeptide (probably via cleavage of a precursor). Two dsRNAs corresponding to the major ssRNAs, and RNA partially resistant to RNase (presumptive RI) are found in infected cells. Minor ssRNAs, two of intermediate length, 4.8 and $4.2 \mathrm{~kb}$ have also been observed; functions of these have not been established. The viral RNAs all appear to be polyadenylated and represent nested coterminal transcripts with common 3'-ends. Capsid polypeptide is the major protein synthetic product; an uncertain number of additional polypeptides is also synthesized; precursorproduct relationships among them are not fully established. Virions mature in the cytoplasm.

\section{Biological ASPECTS}

Host range

Transmission
Natural - vesicular exanthema of swine virus: swine (pinnipeds ?); San Miguel sea lion virus: pinnipeds, fish, swine; feline calicivirus: felines, dogs; canine calicivirus: dogs. Experimental in vivo - vesicular exanthema of swine virus: horse (some strains); SMSV: monkey. Cell culture-vesicular exanthema of swine and San Miguel sealion viruses: porcine, primate (feline?); feline calicivirus: feline (primate?); canine calicivirus: canine, dolphin.

Biological vectors not known. Mechanical via contaminated food (vesicular exanthema of swine virus), contact, airborne (feline calicivirus). Marine/terrestrial transmission likely with vesicular exanthema of swine and San Miguel sealion viruses.

\section{OTHER MEMBERS}

Feline calicivirus (numerous antigenically related strains) San Miguel sea lion (8 or more serotypes) Canine calicivirus.

\section{Probable members}

Viruses with typical calicivirus morphology have been identified in other animal species including humans, other 
primates, cattle, mink, swine, walruses, dolphins, dogs, rabbits, chickens, reptiles, amphibians and insects, but none of these have been fully characterized. Those from humans and some other species cause gastroenteritis, and are difficult to propagate in cell culture. Other viruses that cause gastroenteritis in humans, generally designated "small round structured viruses", including Norwalk virus and Snow Mountain agent, lack typical calicivirus morphology, but have buoyant density and a single capsid polypeptide typical of caliciviruses.

Limited serological relationships have been found among strains of viruses from humans: little or no serological relationships have been detected among viruses from other species.

Derivation of Name calici: from Latin calix, 'cup' or 'goblet', from cupshaped depressions observed by electron microscopy.

\section{REFERENCES}

Carter, M.J.: Feline calicivirus protein synthesis investigated by Western blotting. Arch. Virol. 108: 69-79 (1989).

Crandell, R.A.: Isolation and characterization of caliciviruses from dogs with vesicular genital disease. Arch. Virol. 98: 65-71 (1988).

Cubitt, W.D.: Diagnosis, occurrence and clinical significance of the human 'candidate' caliciviruses. Progr. Med. virol. 36: 103-119 (1989).

Hayashi, Y.; Ando, T.; Utagawa, E.; Sekine, S.; Okada, S.; Yabuuchi, K.; Miki, T.; Ohashi, M.: Western blot (immunoblot) assay of small, round-structured virus associated with an acute gastroenteritis outbreak in Tokyo. J. Clin. Microbiol. 27: 1728-1733 (1989).

Neill, J.D.; Mengeling, W.L.: Further characterization of the virus-specific RNAs in feline calicivirus infected cells. Virus Res. 11: 59-72 (1988).

Ohlinger, V.F.; Haas, B.; Ahl, R.; Weiland, F.: Die infektiose hamorrhagische Krankheit der Kaninchen-eine durch ein Calicivirus verursachte Tierseuche. Z. Geb. Veterinarmed. 44: 284-294 (1989).

Schaffer, F.L.: Caliciviruses, In Fraenkel-Conrat, H.; Wagner, R.R. (eds.), Comprehensive Virology, Vol. 14, pp. 249-284 (Plenum Press, New York, 1979).

Schaffer, F.L.; Bachrach, H.L.; Brown, F.; Gillespie, J.H.; Burroughs, J.N.; Madin, S.H.; Madeley, C.R.; Povey, R.C.; Scott, F.; Smith, A.W.; Studdert, M.J.: Caliciviridae. Intervirology 14:1-6 (1980).

Smith, A.W.; Boyt, P.M.: Caliciviruses of Ocean Origin: A Review. J. Zoo Wildlife Med. 21: 3-23 (1990).

Studdert, M.J.: Caliciviruses: a brief review. Arch. Virol. 58:157-191 (1978). 


\begin{tabular}{lll}
\hline TYPE MEMBER & $\begin{array}{l}\text { CARNATION MOTTLE VIRUS } \\
(\text { CARMV) (7) }\end{array}$ & - \\
\hline
\end{tabular}

Morphology

\section{Properties of The Virus Particle}

Physicochemical properties

Nucleic acid

Protein

\section{Lipid}

Carbohydrate

Antigenic properties
Isometric particles with rounded outline, $33 \mathrm{~nm}$ in diameter. The X-ray crystallographic structure of the closely related turnip crinkle virus has been resolved at $3.2 \AA$. The virions are composed of 180 protein subunits that are structurally similar to those of tomato bushy stunt virus with two globular domains (P and $\mathrm{S}$ ) and an $\mathrm{N}$ terminal basic domain.

$\mathrm{MW} \approx 8.2 \times 10^{6} ; \mathrm{S}_{20 \mathrm{w}} \approx 122$; buoyant density in $\mathrm{CsCl} \approx$ $1.35 \mathrm{~g} / \mathrm{cm}^{3}$.

One molecule of positive sense ssRNA, MW $\approx 1.3 \times 10^{6}$ $(4003 \mathrm{nt}) ; 17 \%$ by weight of virus. The genomes of both CarMV and turnip crinkle virus (4051 nt) have been sequenced and infectious transcripts have been produced from full-length genomic clones of turnip crinkle virus. Satellite RNAs and defective interfering RNAs have been reported for turnip crinkle virus.

One major coat polypeptide, $\mathrm{MW} \approx 38 \times 10^{3}$.

None reported.

None reported.

Good immunogens. Single precipitin line in gel-diffusion tests; no serological cross reactivity between members.

\section{REPLICATION}

The $4 \mathrm{~kb}$ viral genomic RNA encodes a gene product, MW $\approx 27 \times 10^{3}$ and two potential readthrough polypeptides of 86 and $98 \times 10^{3}$. Two viral-specific 3'-coterminal, subgenomic RNAs of 1.7 and $1.5 \mathrm{~kb}$ code for a putative $\mathrm{MW}=7 \times 10^{3}$ protein and the coat protein, respectively. Three viral-specific dsRNA species $(4.0,1.7$ and $1.5 \mathrm{kbp})$ corresponding to each of the viral specific ssRNA species have been detected in infected tissues. Virus particles have been located in the cytoplasm, vascular tissues and within the nucleus, and are associated with cytoplasmic membranes. The genome features of turnip crinkle virus 
are very similar to those of CarMV including open reading frames corresponding to a $\mathrm{MW}=28 \times 10^{3}$ gene product and an $\mathrm{MW}=88 \times 10^{3}$ readthrough product, both of which are necessary for replication in protoplasts. Encoded gene products of $\mathrm{MW}=8 \times 10^{3}$ and the $38 \times 10^{3}$ coat protein are required for systemic infection in plants.

\section{Biological ASPECTS}

Host range

Transmission
Wide among angiosperms.

Readily transmitted by mechanical inoculation. Acquisition through soil is possible. Melon necrotic spot virus is transmitted in nature by the chytrid fungus Olpidium radicale.

\section{SEQUENCE SIMILARITIES WITH OTHER VIRUS GROUPS OR FAMILIES}

The non-structural gene sequences of carmoviruses (CarMV and turnip crinkle virus) show striking similarity to analogous regions of maize chlorotic mottle virus and members of the tombusviruses, dianthoviruses and luteoviruses. The sequence conservation typical of the putative RNA polymerase domains (GDD motif) among members of the Sindbis virus superfamily is evident although sequence motifs for other conserved regions are not present.

\section{OTHER MEMbERS}

Cucumber soil-borne

Galinsoga mosaic (252)

Hibiscus chlorotic ringspot (227)

Melon necrotic spot (302)

Pelargonium flower break (130)

Saguaro cactus (148)

Turnip crinkle (109)

\section{Possible members}

Bean mild mosaic (231)

Blackgram mottle (237)

Cowpea mottle (212)

Cucumber leaf spot (319)

Elderberry latent (127)

Glycine mottle

Narcissus tip necrosis (166)

Plantain 6

Tephrosia symptomless 
Derivation of carmo: sigla from carnation mottle virus.

Name

\section{REFERENCES}

Carrington, J.C.; Heaton, L.A.; Zuidema, D.; Hillman, B.I.; Morris, T.J.: The genome structure of turnip crinkle virus. Virology 170: 219-226 (1989).

Guilley, H.; Carrington, J.C.; Balazs, E.; Jonard, G.; Richards, K.; Morris, T.J.: Nucleotide sequence and genome organization of carnation mottle virus RNA. Nuc. Acids Res. 13: 6663-6677 (1985).

Heaton, L.A.; Carrington, J.C.; Morris, T.J.: Turnip crinkle virus infection from RNA synthesized in vitro. Virology 170: 214-218 (1989).

Hogle, J.M.; Maeda, A.; Harrison, S.C.: Structure and assembly of turnip crinkle virus. I. Xray crystallographic structure analysis at $3.2 \AA$ resolution. J. Mol. Biol. 191: 625-638 (1986).

Li, X.H.; Heaton, L.A.; Morris, T.J.; Simon, A.E.: Turnip crinkle virus defective interfering RNAs intensify viral symptoms and are generated de novo. Proc. Nat. Acad. Sci., USA 86: 9173-9177 (1989).

Morris, T.J.; Carrington, J.C.: Carnation mottle virus and viruses with similar properties. In Koenig, R. (ed.), The Plant Viruses, Polyhedral virions with monopartite RNA genomes, Vol. 3, pp. 73-112. (Plenum Press, New York, 1988).

Nutter, R.C.; Scheets, K.; Panganiban, L.C.; Lommel, S.A.: The complete nucleotide sequence of the maize chlorotic mottle virus genome. Nuc.Acids Res. 17: 3163-3177 (1989). 


\begin{tabular}{|ll|}
\hline FAMILY & SSRNA PHAGES \\
\hline
\end{tabular}

Revised by H.-W. Ackermann

Morphology

Physicochemical properties

Nucleic acid

Protein

Lipid

Carbohydrates

Host range

\section{Properties of The Virus Particle}

Quasi-icosahedral, $\approx 24 \mathrm{~nm}$ in diameter, probably 32 capsomers $(T=3)$, no envelope.

$\mathrm{MW} \approx 4.0 \times 10^{6} ; \mathrm{S}_{20 \mathrm{w}}=79-84$; buoyant density in $\mathrm{CsCl}$ $=1.42-1.47 \mathrm{~g} / \mathrm{cm}^{3}$. Infectivity is ether-, chloroform- and detergent-resistant.

One molecule of linear positive-sense ssRNA; MW $\approx 1.2 \mathrm{x}$ $10^{6} ; 31 \%$ by weight of particle, $\mathrm{G}+\mathrm{C}=51-52 \% ; 3-4$ partly overlapping genes.

180 copies of capsid protein (MW $\left.=12-17 \times 10^{3}\right)$ and one copy of A protein (MW $=35-44 \times 10^{3}$ ), which is required for maturation and infectivity. Capsid proteins may lack histidine or methionine.

None.

None.

\section{REPLICATION}

Adsorption to sides of pili determined by a wide variety of different plasmids. Infecting phage RNA is transcribed into a negative strand which acts as a template for positive strand synthesis. Viral RNA acts as template and as messenger for A protein, coat protein, lysis protein and RNA polymerase. Capsids assemble in cytoplasm around phage RNA. Crystalline arrays in infected bacteria. Virulent, lysis with release of sometimes thousands of particles for each bacterial cell.

\section{Biological ASPECTS}

Enterobacteria, Caulobacter, Pseudomonas.

\section{GENERA}

Coliphage MS2-GA group Coliphage Q $\beta$-SP group 


\begin{tabular}{llc}
\hline \hline GENUS & COLIPHAGE MS2-GA GROUP & LEVIVIRUS \\
\hline TYPE SPECIES & COLIPHAGE MS2 GROUP & - \\
\hline
\end{tabular}

Properties of The Virus Particle

Physicochemical Buoyant density in $\mathrm{CsCl}=1.44-1.46 \mathrm{~g} / \mathrm{cm}^{3}$. Infectivity properties is relatively UV-resistant.

Nucleic acid $\quad M W \approx 1.2 \times 10^{6}$; number of nucleotides is 3,466 for GA and 3,569 for MS2. Four genes; lysis protein gene overlaps coat protein and replicase genes.

Protein Coat protein $\mathrm{MW} \approx 13-14 \times 10^{3}$, maturation protein $\mathrm{MW} \approx$ $45 \times 10^{3}$; no read-through protein.

Antogenic Distinct from members of Allolevivirus genus.

properties

\section{REPLICATION}

Optimal temperature is $37^{\circ} \mathrm{C}$ (MS2 subgroup) or $30^{\circ} \mathrm{C}$ (GA subgroup).

\section{Biological ASPECTS}

Host range Enterobacteria.

\section{OTHER MEMBERS}

a. MS2 subgroup: FH5, fr, f2, M12, R17, $\mu 2$; many others of unknown morphology.

b. GA subgroup: at least 16 others, many of them of unknown morphology.

\begin{tabular}{llc}
\hline \hline GENUS & COLIPHAGE Q $\beta-S P$ GROUP & ALLOLEVIVIRUS \\
\hline TYPE SPECIES & COLIPHAGE Q $\beta$ GROUP & - \\
\hline
\end{tabular}

Properties of The Virus Particle

Physicochemical Buoyant density in $\mathrm{CsCl}=1.47 \mathrm{~g} / \mathrm{cm}^{3}$. Infectivity is properties relatively UV-sensitive.

Nucleic acid $\quad M W \approx 1.4 \times 10^{6}$; number of nucleotides is 4,218 for $\mathrm{Q} \beta$ and 3,569 for SP. Four genes; read-through protein gene overlaps coat protein and replicase genes.

Protein

Coat protein $\mathrm{MW} \approx 16.9-17.3 \times 10^{3}$, maturation protein $\mathrm{MW} \approx 44-48 \times 10^{3}$; read-through protein $\mathrm{MW} \approx 39 \times 10^{3}$. 
Antogenic properties

Distinct from members of Levivirus genus.

\section{REPLICATION}

Optimal temperature is $37^{\circ} \mathrm{C}$.

\section{Biological Aspects}

\section{Host range Enterobacteria.}

\section{OTHER MEMBERS}

a. Q $\beta$ subgroup: at least 12 others, mostly of unknown morphology.

b. SP subgroup: at least 5 others, unknown morphology.

\section{OTHER MEMBERS OF THE FAMILY}

Other members of family not yet allocated to genera.

a. B6, B7, C-1, C2, fcan, Folac, I $\alpha, \mathrm{M}$, pilH $\alpha, \mathrm{R} 23$, R34, ZG/1, ZIK/1, ZJ/1, ZL/3, ZS/3, $\alpha 15, \beta, \mu 2, \tau$, and others (enterobacteria; many plasmid specificities).

b. $\phi \mathrm{Cb} 2, \phi \mathrm{Cb} 4, \phi \mathrm{Cb} 5, \phi \mathrm{Cb} 8 \mathrm{r}, \phi \mathrm{Cb} 9, \phi \mathrm{Cb} 12 \mathrm{r}, \phi \mathrm{Cb} 23 \mathrm{r}$, $\phi \mathrm{CP} 2, \phi \mathrm{CP} 18, \phi \mathrm{Cr} 14, \phi \mathrm{Cr} 28$ (Caulobacter).

c. PRR1, PP7, 7s (Pseudomonas).

Derivation of levi: from Latin levis, 'light'.

Name

\section{REFERENCES}

Ackermann, H.W.; DuBow, M.S.: Viruses of Prokaryotes, Vol. II, pp 171-218 (CRC Press, Boca Raton, Fl., 1987).

Furuse, K.: Distribution of coliphages in the environment. In Goyal, S.M.; Gerber, C.P.; Bitton, G. (eds.), Phage Ecology, pp. 87-124 (John Wiley \& Sons, New York, 1987).

van Duin, J.: Single-stranded RNA bacteriophages. In Calendar, R. (ed.), The Bacteriophages, Vol. 1, pp 117-167 (Plenum Press, New York, 1988).

Zinder, N.D.: RNA phages (Cold Spring Harbor Laboratory, Cold Spring Harbor, 1975). 
GROUP

BARLEY YELLOW DWARF

LUTEOVIRUS VIRUS GROUP (339)

Revised by J.W. Randles

TYPE MEMBER BARLEY YELLOW DWARF VIRUS

(BYDV) - MAV ISOLATE (32)

\section{Properties of the Virus Particle}

Morphology Isometric particles, $25-30 \mathrm{~nm}$ in diameter.

Physicochemical properties

Nucleic acid

Protein

Lipid

Carbohydrate

Antigenic properties

Host range

Transmission
$\mathrm{MW} \approx 6.5 \times 10^{6} ; \mathrm{S}_{20 \mathrm{w}}=104-118$; buoyant density $\approx$ $1.40 \mathrm{~g} / \mathrm{cm}^{3}$ in CsCl. Moderately stable.

One molecule of positive-sense ssRNA MW $\approx 2.0 \times 10^{6}$ with Vpg at 5'-end and containing 6 ORFs. 'Satellite' RNAs are associated with some barley yellow dwarf virus (RPV) isolates.

One coat polypeptide, $\mathrm{MW} \approx 24 \times 10^{3} .180$ protein subunits arranged in a $\mathrm{T}=3$ icosahedral lattice.

None reported.

None reported.

Strongly immunogenic. Many members are serologically related.

\section{REPLICATION}

Confined to phloem tissues of infected plants. Details of ultra-structural changes vary among members.

\section{Biological Aspects}

Varies with member - some infect wide range of monocotyledonous plants, others infect many dicotyledonous plants, and some are restricted to smaller plant groups.

Persistent transmission by aphid vectors; virus apparently does not replicate in vector. Pronounced vector specificity among some virus isolates. Not transmitted by mechanical inoculation to plants, but aphids are rendered inoculative by injection. Not transmitted through seed. Several members are associated with systems of dependent virus transmission by aphids from mixed infections in the host . 


\section{OTHER MEMBERS}

Characterized isolates of BYDV fall into two groups on the basis of serological properties and cytological effects:

I. MAV, PAV, and SGV

II. RPV, RMV and rice giallume (RGV)

Bean leaf roll (286) (= legume yellows, Michigan alfalfa, pea leaf roll)

Beet western yellows (89) (= beet mild yellowing, Malva yellows, turnip yellows)

Carrot red leaf (249)

Groundnut rosette assistor

Indonesian soybean dwarf

Potato leaf roll $(36 ; 291)$

(= Solanum yellows, tomato yellow top)

Soybean dwarf (179) edge)

(= subterranean clover red leaf, strawberry mild yellow

Tobacco necrotic dwarf (234)

\section{Possible members}

Beet yellow net

Celery yellow spot

Cotton anthocyanosis

Filaree red leaf

Milk vetch dwarf

Millet red leaf

Physalis mild chlorosis

Physalis vein blotch

Raspberry leaf curl

Tobacco vein distorting

Tobacco yellow net

Tobacco yellow vein assistor

Derivation of Name from Latin luteus, 'yellow', from yellowing symptoms shown by infected hosts. 


\section{REFERENCES}

Diaco, R.; Lister, R.M.; Hill, J.H.; Durand, D.P.: Demonstration of serological relationships among isolates of barley yellow dwarf virus by using polyclonal and monoclonal antibodies. J. gen. Virol. 67:353-362 (1986).

Duffus, J.E.; Falk, B.W.; Johnstone, G.R.: Luteoviruses - one system, many variations; in Burnett, World Perspectives on Barley Yellow Dwarf, pp. 86-104. (CIMMYT, Mexico, 1990).

Francki, R.I.B.; Milne, R.G.; Hatta, T.: Luteovirus group, In Atlas of Plant Viruses, Vol. I, pp 137-152 (CRC Press, Boca Raton, Fl., 1985).

Iwaki, M.; Roechan, M.; Hibino, H.; Tochihara, H.; Tantera, D.M.: A persistent aphid-borne virus of soybean, Indonesian soybean dwarf virus. Plant Dis. 64:1027-1030 (1980).

Johnstone, G.R.; Ashby, J.W.; Gibbs, A.J.; Duffus, J.E.; Thottapilly, G.; Fletcher, J.D.: The host ranges, classification and identification of eight persistent aphid-transmitted viruses causing diseases in legumes. Neth. J. Pl. Path. 90:225-245 (1984).

Martin, R.R.; D'Arcy, C.J.: Relationships among luteoviruses based on nucleic acid hybridization and serological studies. Intervirology 31: 23-30 (1990).

Mayo, M.A.; Robinson, D.J.; Jolly, C.A.; Hyman, L.: Nucleotide sequence of potato leafroll luteovirus RNA. J. gen. Virol. 70: 1037-1051 (1989).

Miller, W.A.; Hercus, T.; Waterhouse, P.M.; Gerlach, W.L.: Characterization of a satellite RNA associated with a luteovirus. 7th Intl. Congr. Virology, Edmonton. Abstracts, p. 299 (1987).

Miller, W.A.; Waterhouse, P.M.; Gerlach, W.L.: Sequence and organization of barley yellow dwarf virus genomic RNA. Nuc. Acids Res. 16: 6097-6111 (1988).

Murphy, J.F.; D'Arcy, C.J.; Clark, J.M.: Barley yellow dwarf virus RNA has a 5'-terminal genome-linked protein. J. gen. Virol. 70: 2253-2256 (1989).

Thomas, J.E.: Characterisation of an Australian isolate of tomato yellow top virus. Ann. appl. Biol. 104:79-86 (1984).

Yu, T.F.; Hsu, H.-K.; Pei, M.-Y.: Studies on the red-leaf disease of the foxtail millet [Setaria italia,(L) Beauv.]. II. Cultivated and wild hosts of millet red leaf virus. Acta Phytopath. Sin. 4:1-7 (1958). 


\begin{tabular}{|lll|}
\hline GROUP & $\begin{array}{l}\text { MAIZE CHLOROTIC DWARF } \\
\text { VIRUS GROUP }\end{array}$ & - \\
\hline
\end{tabular}

Revised by R.I. Hamilton

\begin{tabular}{lll}
\hline TYPE MEMBER & MAIZE CHLOROTIC DWARF & - \\
& VIRUS (MCDV) (194)
\end{tabular}

\section{Properties of the Virus Particle}

Morphology Polyhedral particles $\approx 30 \mathrm{~nm}$ in diameter.

Physicochemical $\mathrm{MW} \approx 8.8 \times 10^{6} ; \mathrm{S}_{20 \mathrm{w}} \approx 183$; density in $\mathrm{CsCl} \approx 1.51$ properties $\mathrm{g} / \mathrm{cm}^{3}$.

Nucleic acid One molecule of positive-sense ssRNA, MW $=3.2 \times 10^{6}$.

Protein Three proteins, MW $\approx 34,25$ and $22.5 \times 10^{3}$ have been isolated from purified virus.

Lipid None reported.

Carbohydrate None reported.

Antigenic Efficient immunogens.

properties

\section{REPLICATION}

No subgenomic RNAs found. Probably translated as polyprotein that is cleaved to produce functional proteins.

\section{Biological ASPECTS}

Host range Narrow, limited to members of Gramineae.

Transmission Only by leafhoppers in a semi-persistent manner. A virusencoded helper component is required for transmission. The principal vector is Graminella nigrifons.

\section{OTHER MEMBERS}

Possible members

Rice tungro spherical (67)

Anthriscus yellows 


\section{REFERENCES}

Choudhury, M.M.; Rosenkranz, E.: Vector relationship of Graminella nigrifons to maize chlorotic dwarf virus. Phytopathology 73:685-690 (1983).

Gingery, R.E.: Maize chlorotic dwarf and related viruses; In Koenig, R. (ed.), The plant viruses, Polyhedral virions with monopartite RNA genomes, Vol. 3, pp. 259-272 (Plenum Press, New York, 1988).

Hemida, S.K.; Murant, A.F.; Duncan, G.H.: Purification and some particle properties of anthriscus yellows virus, a phloem-limited semi-persistent aphid-borne virus. Ann. appl. Biol. 114: 71-86 (1989).

Hunt, R.E.; Nault, L.R.; Gingery, R.E.: Evidence for infectivity of maize chlorotic dwarf virus and for a helper component in its leafhopper transmission. Phytopathology 78: 499-504 (1988). 


\begin{tabular}{|ll|}
\hline GROUP & $\begin{array}{l}\text { MAIZE RAYADO FINO } \\
\text { VIRUS GROUP }\end{array}$ \\
\hline
\end{tabular}

Revised by K. Tomaru

\begin{tabular}{lll}
\hline TYPE MEMBER & MAIZE RAYADO FINO & - \\
& VIRUS (MRFV) (200) & \\
\hline
\end{tabular}

\section{Properties of The Virus Particle}

Morphology Polyhedral particles $\approx 31 \mathrm{~nm}$ diameter.

Physicochemical Two major classes of particles (B and T); $\mathrm{S}_{20 \mathrm{w}} \approx 120$ and properties 54 , respectively; buoyant densities in $\mathrm{CsCl} \approx 1.46$ and 1.28 .

Nucleic acid

One molecule of linear ssRNA with MW $=2.0-2.4 \times 10^{6}$, accounting for $25-30 \%$ of the B particle weight.

Protein

One major protein $\left(\mathrm{MW} \approx 22 \times 10^{3}\right)$ and a minor one $(\mathrm{MW}$ $\approx 28 \times 10^{3}$ ) reported for different isolates of MRFV; both proteins contain common peptide sequences. Single protein $\left(\mathrm{MW} \approx 27 \times 10^{3}\right)$ detected in bermuda grass etchedline virus.

\section{Lipid None reported.}

Carbohydrate None reported.

Antigenic properties

Moderately immunogenic. Serological relationships among members.

\section{REPLICATION}

Virions are found in vacuoles of collenchyma and phloem parenchyma cells but also occur in the cytoplasm either dispersed, in single rows in long tubules, or in crystal-like arrays. Viral RNA is translated in vitro in rabbit reticulocyte lysates to yield polypeptides of MW ranging from $15-165 \times 10^{3}$. No polypeptides with electrophoretic or serological properties of coat protein are obtained by in vitro translation.

\section{BIOLOGICAL ASPECTS}

Host range Individual members may have broad host ranges; hosts are restricted to the Gramineae. 
Taxonomic status

English vernacular name

International name

Transmission Transmitted naturally by leafhoppers; manual transmission is difficult. Replication of MRFV in its vector is suggested by serial passage experiments.

\section{MEMBERS}

Bermuda grass etched-line

Oat blue dwarf (123)

Derivation of

Name

marafi: Sigla from maize rayado fino

\section{REFERENCES}

Banttari, E.E.; Moore, M.B: Virus cause of blue dwarf of oats and its transmission to barley and flax. Phytopathology 52:897-902 (1962).

Banttari, E.E.; Zeyen, R.J.: Chromatographic purification of the oat blue dwarf virus. Phytopathology 59:183-186 (1969).

Espinoza, A.M.; Ramirez, P.; Leon, P.: Cell-free translation of maize rayado fino virus genomic RNA. J. gen. Virol. (in press).

Falk, B.W.; Tsai, J.H.: The two capsid proteins of maize rayado fino virus contain common peptide sequences. Intervirology 25:111-116 (1986).

Gamez, R.: Transmission of rayado fino virus of maize (Zea mays) by Dalbulus maidis . Ann. appl. Biol. 73:285-292 (1973).

Gingery, R.E.; Gordon, D.T.; Nault, L.R.: Purification and properties of an isolate of maize rayado fino virus from the United States. Phytopathology 72:1313-1318 (1982).

Leon, P.; Gamez, R.: Biologia molecular del virus del rayado fino del maiz. Rev. Biol. Trop. 34:111-114 (1986).

Leon, P.; Gamez, R.: Some physicochemical properties of maize rayado fino virus. J. gen. Virol. 56:67-75 (1981).

Lockhart, B.E.L.; Khaless, N.; Lennon, A.M.; El Maatauoi, M.: Properties of Bermuda grass etched-line virus, a new leafhopper-transmitted virus related to maize rayado fino and oat blue dwarf viruses. Phytopathology 75:1258-1262 (1985).

Pring, D.R.; Zeyen, R.J.; Banttari, E.E.: Isolation and characterization of oat blue dwarf virus ribonucleic acid. Phytopathology 63:393-396 (1973).

Rivera, C.; Gamez, R.: Multiplication of maize rayado fino virus in the leafhopper vector Dalbulus maidis. Intervirology 25:76-82 (1986). 
Revised by J.W. Randles

\begin{tabular}{lll}
\hline TYPE MEMBER & $\begin{array}{l}\text { TOBACCO NECROSIS VIRUS } \\
\text { (TNV)(A STRAIN) (14) }\end{array}$ & - \\
\hline
\end{tabular}

Morphology

Physicochemical properties

Nucleic acid

Protein

Lipid

Carbohydrate

Antigenic properties

\section{Properties of the Virus Particle}

Polyhedral particles $\approx 28 \mathrm{~nm}$ in diameter consisting of 180 protein subunits arranged in a $\mathrm{T}=3$ icosahedral lattice. Isolates may be associated with a satellite virus (satellite TNV, $17 \mathrm{~nm}$ ) which depends on TNV for replication of its RNA (1239 nt) but which codes for its own coat protein (195 residues).

$\mathrm{MW} \approx 7.6 \times 10^{6} ; \mathrm{S}_{20 \mathrm{w}} \approx 118$; buoyant density in $\mathrm{CsCl} \approx$ $1.40 \mathrm{~g} / \mathrm{cm}^{3}$.

One molecule of linear positive-sense ssRNA, MW $=1.3$ $1.6 \times 10^{6} ; 5$ - terminus has the sequence ppApGpUp...

Single polypeptide, $\mathrm{MW}=22.6-33.3 \times 10^{3}$.

None reported.

None reported.

Moderately immunogenic. Single precipitin line in gel diffusion tests.

\section{REPLICATION}

A virus-induced RNA-dependent polymerase occurs in infected plants. Three dsRNAs have been detected in infected tissue. One ( $\left.\mathrm{MW} \approx 2.6 \times 10^{6}\right)$ appears to be the replicative form (RF) for genomic RNA; the others (1.05 and $0.94 \times 10^{6}$ ) may be RFs of subgenomic RNAs. Crystal-like aggregates of virus particles often seen in cytoplasm of infected cells.

\section{Biological ASPECTS}

Host range

Wide among angiosperms: usually restricted to roots in natural infections. 
Transmission Transmitted naturally by the chytrid fungus Olpidium brassicae, and experimentally by mechanical inoculation of sap.

\section{OTHER MEMBERS}

Chenopodium necrosis

Possible members

Carnation yellow stripe

Lisianthus necrosis

Derivation of

necro: from Greek nekros, "dead body".

Name

\section{REFERENCES}

Condit, C.; Fraenkel-Conrat, H.: Isolation of replicative forms of 3 ' terminal subgenomic RNAs of tobacco necrosis virus. Virology 97:122-130 (1979).

Francki, R.I.B.; Milne, R.G.; Hatta, T.: Tobacco necrosis virus group, In Atlas of Plant Viruses, Vol. I, pp 171-180 (CRC Press, Boca Raton, Fl., 1985).

Gallitelli, D.; Castellano, M.A.; Di Franco, A.; Rana, G.I.L.: Properties of carnation yellow stripe virus, a member of the tobacco necrosis virus group. Phytopathol. Medit. 18:3140 (1979).

Gama, M.I.C.S.; Kitajima, E.W.; Lin, M.T.: Properties of a tobacco necrosis virus isolate from Pogostemum patchuli in Brazil. Phytopathology 72:529-532 (1982).

Iwaki, M.; Hanada, K.; Maria, E.R.A.; Onogi, S.: Lisianthus necrosis virus, a new necrovirus from Eustoma russellianum. Phytopathology 77: 867-870 (1987).

Lesnaw, J.A.; Reichmann, M.E.: The structure of tobacco necrosis virus. I. The protein subunit and the nature of the nucleic acid. Virology 39:729-737 (1969).

Stussi-Garaud, C.; Lemius, J.: Fraenkel-Conrat, H.: RNA polymerase from tobacco necrosis virus-infected and uninfected tobacco. Virology 81:224-236 (1977).

Tomlinson, J.A.; Faithfull, E.M.; Webb, M.J.W.; Fraser, R.S.S.; Seeley, N.D.: Chenopodium necrosis: a distinctive strain of tobacco necrosis virus isolated from river water. Ann. appl. Biol. 102: 135-147 (1983).

Uyemoto, J.K.: Tobacco necrosis and satellite viruses; In Kurstak, E. (ed.), Handbook of Plant Virus Infections and Comparative Diagnosis, pp. 123-146. (Elsevier/North Holland, Amsterdam, 1981). 
Compiled by A.F. Murant

\begin{tabular}{lll}
\hline TYPE MEMBER & PARSNIP YELLOW FLECK & - \\
& VIRUS (PYFV) \\
& (PARSNIP STRAIN) (129) \\
\hline
\end{tabular}

\section{Properties of the Virus Particle}

Morphology

Isometric particles $\approx 30 \mathrm{~nm}$ in diameter. Particles of $\mathrm{T}$ component are penetrated by negative stain.

Physicochemical properties

Nucleic acid

Protein

Lipid

Carbohydrate

Antigenic properties

Host range
Particles sediment as two components, $\mathrm{T}$ and $\mathrm{B}$, respectively containing $\approx 0$ and $42 \%$ RNA and with $S_{20}$ w of 60 and 153; buoyant density in $\mathrm{CsCl} \approx 1.3(\mathrm{~T})$ and 1.5 (B).

One molecule of infective positive-sense linear ss-RNA of $\mathrm{MW} \approx 3.5 \times 10^{6}$. The molecule is polyadenylated at the $3^{\prime}-$, and a Vpg at the 5'-end.

Three major polypeptides, $\mathrm{MW} \approx 31,26$ and $23 \times 10^{3}$.

None reported.

None reported.

Efficient immunogens.

\section{REPLICATION}

Large inclusion bodies occur in infected cells adjacent to the nucleus. They contain vesicular structures, granular bodies, amorphous matrix material and straight tubules $\approx$ $30 \mathrm{~nm}$ in diameter; mitochondria occur around the periphery. Only the amorphous matrix material is labelled with gold conjugate to PYFV antibody. Virus particles in the cytoplasm often occur within tubules $\approx 45 \mathrm{~nm}$ in diameter, which may pass through plasmodesmata.

\section{Biological Aspects}

Natural host range restricted. Experimental host range moderate to narrow. Symptoms are mottles and mosaics; in some species, wilting and necrosis. 

in association with a helper virus. No evidence for multiplication of virus in the vector. No seed-transmission reported. Transmissible experimentally by mechanical inoculation.

\section{OTHER MEMBERS}

Parsnip yellow fleck, Anthriscus strain (129)

\section{Possible member}

Dandelion yellow mosaic

\section{REFERENCES}

Bos, L.; Huijberts, N.; Huttinga, H.; Maat, D.Z.: Further characterization of dandelion yellow mosaic virus from lettuce and dandelion. Neth. J. Pl. Path. 89:207-222 (1983).

Elnagar, S.; Murant, A.F.: Relations of the semi-persistent viruses, parsnip yellow fleck and anthriscus yellows, with their vector, Cavariella aegopodii. Ann. appl. Biol. 84:153-167 (1976).

Elnagar, S.; Murant, A.F.: The role of the helper virus, anthriscus yellows, in the transmission of parsnip yellow fleck virus by the aphid Cavariella aegopodii. Ann. appl. Biol. 84:169-181 (1976).

Fasseas, C.; Roberts, I.M.; Murant, A.F.: Immunogold localization of parsnip yellow fleck virus particle antigen in thin sections of plant cells. J. gen. Virol. 70: 2741-2749 (1989).

Hemida, S.K.; Murant, A.F.: Particle properties of parsnip yellow fleck virus. Ann. appl. Biol. 114: 87-100 (1989).

Hemida, S.K.; Murant, A.F.: Host ranges and serological properties of eight isolates of parsnip yellow fleck virus belonging to the two major serotypes. Ann. appl. Biol. 114: 101-109 (1989).

Murant, A.F.: Parsnip yellow fleck virus, type member of a proposed new plant virus group, and a possible second member, dandelion yellow mosaic virus; In Koenig, R. (ed.), The plant viruses. Polyhedral virions with monopartite RNA genomes, Vol. 3, pp. 273-288 (Plenum Press, New York, London, 1988).

Murant, A.F.; Goold, R.A.: Purification, properties and transmission of parsnip yellow fleck, a semi-persistent, aphid-borne virus. Ann. appl. Biol. 62:123-137 (1968).

Murant, A.F.; Roberts, I.M.; Elnagar, S.: Association of virus-like particles with the foregut of the aphid Cavariella aegopodii transmitting the semi-persistent viruses anthriscus yellows and parsnip yellow fleck. J. gen. Virol. 31:47-57 (1976).

Murant, A.F.; Roberts, I.M.; Hutcheson, A.M.: Effects of parsnip yellow fleck virus on plant cells. J. gen. Virol. 26:277-285 (1975). 
Morphology

Physicochemical properties

Nucleic acid

Protein

Lipid

Carbohydrate

Antigenic properties
Reported by P. Minor

\section{Properties of The Virus Particle}

Virions are icosahedra $(T=1)$ with no envelope; the core consists of RNA and a small protein 3B VPg covalently linked to its 5'-end. Electron micrographs (EM) reveal no projections, the surface being almost featureless. Hydrated native particles are $30 \mathrm{~nm}$ in diameter but vary from 22-30 $\mathrm{nm}$ by EM due to drying and flattening during preparation. Sometimes form long ribonucleoprotein strands upon heating at slightly alkaline $\mathrm{pH}$.

MW $=8-9 \times 10^{6} ; S_{20 \mathrm{w}}=140-165$; buoyant density in $\mathrm{CsCl}=1.33-1.45 \mathrm{~g} / \mathrm{cm}^{3}$ depending mainly on genus. Some species are unstable below $\mathrm{pH}$ 6; many are less stable at low ionic strength than at high. Insensitive to ether, chloroform or non-ionic detergents. Inactivated by light when grown with, or in the presence of, dyes such as neutral red and proflavin.

One molecule of infectious positive-sense ssRNA, MW = 2.4-2.7 $\times 10^{6}$. A poly A tract, heterogeneous in length, is transcribed onto the 3 -terminus. A protein, $\mathrm{VPg}(\mathrm{MW} \approx$ 2,400 ), is linked covalently to the 5 -terminus.

Capsid of 60 protein subunits (protomers), each consisting of four polypeptides (three of MW $=24-41 \times 10^{3}$ and one of MW $=5.5-13.5 \times 10^{3}$ ) derived by cleavage of a single polyprotein. Protomers vary from $80 \mathrm{kDa}$ for aphthovirus to 97 for poliovirus and some may be incompletely cleaved. The atomic structures of representatives of four of the picornavirus genera have been solved and are very similar to each other and to the icosahedral plant viruses.

None. Some strains of poliovirus may carry 60 molecules each of a sphingosine-like molecule. The inner capsid polypeptide 1A (VP4) has a molecule of myristic acid covalently attached to the amino terminal end.

None.

Native virions are antigenically specific (designated "N" or "D"), but after gentle heating are converted to group specificity (designated " $\mathrm{H} ")$. Neutralization by antibody follows first-order inactivation kinetics. Species (equivalent to serotypes) are classified by neutralization of 
infectivity, complement-fixation or immunodiffusion; some species can be identified by hemagglutination. Neutralization epitopes defined by resistance mutations to monoclonal antibodies typically number 3 or 4 per protomer.

\section{REPLICATION}

Replication of viral RNA occurs in complexes associated with cytoplasmic membranes apparently via two distinct RIs. One complex uses positive- strand RNA and the other uses negative-strand RNA as template. Functional proteins are mainly produced from a single large ( $\mathrm{MW}=$ $240-250 \times 10^{3}$ ) polyprotein by post-translational cleavage. The precursor protein is cleaved during translation and thus not normally detectable. Coat protein is encoded by the 5' half; VPg, proteases and polymerases or polymerase factors are encoded downstream. Many compounds specifically inhibiting replication have been described. Mutants resistant to and dependent on mutants drugs are often easily obtained. Genetic recombination, complementation and phenotypic mixing occur. DI particles have been produced experimentally but are probably not very important in nature because they appear only under extreme selection pressure.

\section{Biological ASPECTS}

Host range

Nature: Most species are host-specific. Exceptions include coxsackie B5 virus, EMC virus and aphthoviruses; serologic tests suggest they pass occasionally between man and domestic (cloven-footed) animals.

Laboratory: Most species can be grown in cell cultures. Resistant host cells can often be infected (single round) by transfection with naked infective RNA. Rhinoviruses and many enteroviruses grow poorly or not at all in laboratory animals.

Transmission Horizontal, mainly mechanically.

\section{GENERA}

Enterovirus group

Hepatitis A virus group

EMC virus group

Common cold virus group

Foot-and-mouth disease virus group
Enterovirus

Hepatovirus

Cardiovirus

Rhinovirus

Aphthovirus 


\begin{tabular}{llc}
\hline \hline GENUS & ENTEROVIRUS GROUP & ENTEROVIRUS \\
\hline TYPE SPECIES & HUMAN POLIOVIRUS 1 & - \\
\hline
\end{tabular}

\section{Properties of The Virus Particle}

Stable at acid $\mathrm{pH}$; buoyant density in $\mathrm{CsCl}=1.30-1.34$ $\mathrm{g} / \mathrm{cm}^{3}$; empty shells often observed with virus; very small amounts (1\%) of high density particles (1.43) sometimes observed. Primarily viruses of gastrointestinal tract, but also multiply in other tissues such as nerve, muscle, etc.

\section{Biological Aspects}

Infection may frequently be asymptomatic. Clinical manifestations may include mild gastrointestinal symptoms, meningitis, paralysis, cardiac symptoms, conjunctivitis and hand, foot and mouth disease.

\section{OTHER MEMBERS}

Human polioviruses 2-3

Human coxsackieviruses A1-22, 24 (A23 = echovirus 9) 1

Human coxsackieviruses B1-6 (swine vesicular disease virus is very similar to coxsackievirus B5)

Human echoviruses 1-9, 11-27, 29-34

Human enteroviruses 68-71

Vilyuisk virus

Murine poliovirus (Theiler's encephalomyelitis virus, TO, FA, GD7)

Simian enteroviruses 1-18

Porcine enteroviruses 1-8

Bovine enteroviruses 1-2

\begin{tabular}{llr}
\hline \hline GENUS & HEPATITIS A VIRUS GROUP & HEPATOVIRUS \\
\hline TYPE SPECIES & $\begin{array}{l}\text { HUMAN HEPATITIS A VIRUS } \\
\text { (STRAIN HM 175) }\end{array}$ \\
\hline
\end{tabular}

\section{Properties of the Virus Particle}

Very stable, resistant to acid $\mathrm{pH}$ and elevated temperature $\left(60^{\circ} \mathrm{C}\right.$ for $\left.10 \mathrm{~min}\right)$. Buoyant density in $\mathrm{CsCl}=1.32-1.34$ $\mathrm{g} / \mathrm{cm}^{3}$. Primarily viruses of liver, found in faeces at high titre shortly before clinical signs of hepatitis develop. Strongly conserved antigenic properties and tendency to establish persistent virus infections in vitro. VP4 is small. Genomic sequences show no detectable similarity with entero or rhinoviruses. 


\section{BIOLOGICAL ASPECTS}

Clinical manifestations are hepatitis.

OTHER MEMBERS

Simian hepatitis A virus.

\begin{tabular}{llc}
\hline \hline GENUS & EMC VIRUS GROUP & CARDIOVIRUS \\
\hline TYPE SPECIES & $\begin{array}{l}\text { ENCEPHALOMYOCARDITIS } \\
\text { (EMC) VIRUS }\end{array}$ & - \\
\hline
\end{tabular}

Properties of the Virus Particle

Unstable at $\mathrm{pH}$ 5-6 in presence of $0.1 \mathrm{M}$ halide; buoyant density in $\mathrm{CsCl}=1.33-1.34 \mathrm{~g} / \mathrm{cm}^{3}$; single serotype. Poly(C) tract of variable length (80-250 bases) about 150 bases from 5' terminus of RNA. Empty shells seen rarely, if ever.

\section{Biological ASPECTS}

Clinical manifestations include encephalitis and myocarditis in mice.

\section{OTHER MEMBERS}

Mengovirus

Murine encephalomyelitis (ME) virus

Columbia SK virus

$\mathrm{MM}$ virus

\begin{tabular}{llc}
\hline \hline GENUS & COMMON COLD VIRUS GROUP & RHINOVIRUS \\
\hline TYPE SPECIES & HUMAN RHINOVIRUS 1A & - \\
\hline
\end{tabular}

Properties of The Virus PaRTiCle

Unstable below pH 5-6; buoyant density in $\mathrm{CsCl}=1.38$ $1.42 \mathrm{~g} / \mathrm{cm}^{3}$.

\section{Biological ASPECTS}

Clinical manifestations include the common cold in humans.

\section{OTHER MEMBERS}

Human rhinoviruses 1B-100

Bovine rhinoviruses 1 and 2 


\begin{tabular}{llc}
\hline \hline GENUS & FOOT-AND-MOUTH DISEASE & APHTHOVIRUS \\
& VIRUS GROUP & \\
\hline TYPE SPECIES & APHTHOVIRUS O & - \\
\hline
\end{tabular}

\section{Properties of The Virus Particle}

Unstable below $\mathrm{pH} 5-6$; buoyant density in $\mathrm{CsCl}=1.43$ $1.45 \mathrm{~g} / \mathrm{cm}^{3}$; clinical manifestations. Poly $(\mathrm{C})$ tract of variable length (100-170 bases), about 400 bases from $5^{\prime}$ terminus of RNA. The genome encodes 3 species of VPg.

\section{BIOlOGiCAL ASPECTS}

Clinical manifestations include foot and mouth disease of cloven hoofed animals.

OTHER MEMBERS

A

C

SAT1

SAT2

SAT3

Asia 1

OTHER MEMBERS OF FAMILY PICORNAVIRIDAE NOT YET ASSIGNED TO GENERA

Equine rhinoviruses types 1 and 2

Cricket paralysis virus

Drosophila C virus

Gonometa virus

\section{UNCLASSIFIED SMALl RNA VIRUSES}

About 30 small RNA viruses of unknown affinities have been described. These include: bee acute paralysis, bee slow paralysis, bee virus $\mathrm{X}$, Drosophila $\mathrm{P}$ and A, sacbrood, Queensland fruitfly virus and Triatoma virus and aphid lethal paralysis virus. Parsnip yellow fleck virus, the type member of the parsnip fleck virus group, has many properties in common with picornaviruses. 
Derivation of

picorna: from the prefix 'pico' (= 'micro-micro') and

Name

RNA (= the sigla for ribonucleic acid).

entero: from Greek enteron, 'intestine'.

rhino: from Greek rhis, rhinos, 'nose'.

cardio: from Greek kardia, 'heart'.

aphtho: from Greek aphtha, 'vesicles in the mouth';

English aphtho, 'thrush'; French fievre aphteuse.

\section{REFERENCES}

Acharya, R.; Fry, E.; Stuart, D.; Fox, G.; Rowlands, D.; Brown, F.: The three dimensional structure of foot-and-mouth disease virus at $2.9 \AA$ resolution. Nature $337: 709-716$ (1989).

Adair, B.M.; Kennedy, S.; McKillop, E.R.; McNulty, M.S.; McFerran, J.B.: Bovine, porcine and ovine picornaviruses: identification of viruses with properties similar to human coxsackieviruses. Arch. Virol. 97:49-60 (1987).

Bashiruddin, J.B.; Martin, J.L.; Reinganum, C.: Queensland fruit fly virus, a probable member of the Picornaviridae. Arch. Virol. 100:61-74 (1988).

Cooper, P.D.; Agol, V.I.; Bachrach, H.L.; Brown, F.; Ghendon, Y.; Gibbs, A.J.; Gillespie, J.H.; Lonberg-Holm, K.; Mandel, B.; Melnick, J.L.; Mohanty, S.B.; Povey, R.C.; Rueckert, R.R.; Schaffer, F.L.; Tyrrell, D.A.J.: Picornaviridae: Second Report. Intervirology 10:165- 180 (1978).

Gust, I.D.; Feinstone, S.M.: In Hepatitis A, p. 56 (CRC Press, Boca Raton, Fl., 1988).

Hamparian, V.V.; et al.: A collaborative report: Rhinoviruses - Extension of the numbering system from 89 to 100 . Virology 159: 191-192 (1987).

Knowles, N.J.; Barnett, I.T.R.: A serological classification of bovine enteroviruses. Arch. Virol. 83:141-155 (1985).

Lipton, H.; Friedmann, A.; Sethi, P.; Crowther, R.R.: Characterization of Vilyuisk virus as a picornavirus. J. Med. Virol. 12:195-204 (1983).

Melnick, J.L.; Agol, V.I.; Bachrach, H.L.; Brown, F.; Cooper, P.D.; Fiers, W.; Gard, S.; Gear, J.H.S.; Ghendon, Y.; Kasza, L.; LaPlaca, M.; Mandel, B.; McGregor, S.; Mohanty, S.B.; Plummer, G.; Rueckert, R.R.; Schaffer, F.L.; Tagaya, I.; Tyrrell, D.A.J.; Voroshilova, M.; Wenner, H.A: Picornaviridae. Intervirology 4:303-316 (1974).

Moore, N.F.; King, L.A.; Pullin, J.S.K.: Insect Picornaviruses. In Rowlands, D.; Mayo, M.A.; Mahy, B. (eds.), The Molecular Biology of the Positive Strand RNA Viruses, pp. 67-74 (Academic Press, New York, 1987).

Murant, A.F.: Parsnip yellow fleck virus, type member of a proposed new plant virus group, and a possible second member, Dandelion Yellow Mosaic Virus, In Koenig, R. (ed.), The Plant Viruses, Polyhedral Virions with Monopartite RNA Genomes, Vol. 3, pp. 273-288 (Plenum Press, New York, 1988).

Muscio, O.A.; La Torre, J.L.; Scodeller, E.A.: Characterization of Triatoma virus, a picornalike virus isolated from the triatomine bug Triatoma infestans. J. gen. Virol. 69:29292934 (1988).

Ozden, S.; Tangy, F.; Chamorro, M.; Brahic, M.: Theiler's virus genome is closely related to that of Encephalomyocarditis virus, the prototype cardiovirus. J. Virol. 60:1163-1165 (1986).

Palmenberg, A.: C. Sequence alignments of picornaviral capsid proteins. In Semler, B.L.; Ehrenfeld, E. (eds.), Molecular Aspects of picornavirus Infection and Detection, pp. 211241 (ASM Press, Washington DC, 1989).

Rueckert, R.R.: Picornaviruses and their multiplication. In Fields: Virology, pp. in press (Raven Press, New York, 1989). 
Tinsley, T.W.; MacCallum, F.O.; Robertson, J.S.; Brown, F.: Relationship of encephalomyocarditis virus to cricket paralysis virus of insects. Intervirology 21:181186 (1984).

Williamson, C.; Rybicki, E.P.; Kasdorf, G.G.F.; von Wechmar, M.B.: Characterization of a new picorna-like virus isolated from aphids. J. gen. Virol. 69:787-795 (1988).

Yamashita, H.; Akashi, H.; Inaba, Y.: Isolation of a new serotype of bovine rhinovirus from cattle. Arch. Virol. 83:1138-116 (1985). 
Revised by E.P. Rybicki

\begin{tabular}{l} 
TYPE MEMBER \\
\hline Morphology \\
Physicochemical \\
properties
\end{tabular}

SOUTHERN BEAN MOSAIC

VIRUS (SBMV) $(57 ; 274)$

\section{Properties of the Virus Particle}

Particles $\approx 30 \mathrm{~nm}$ diameter with 180 subunits in a $\mathrm{T}=3$ icosahedral structure stabilized by divalent cations. Each protein subunit has two domains. One forms parts of the icosahedral shell about $3.5 \mathrm{~nm}$ thick and the other forms a partially ordered 'arm' in the interior of the virus.

Nucleic acid One molecule of positive-sense ssRNA MW $=1.4 \times 10^{6}$ $(\approx 4.2 \mathrm{~kb})$; Vpg, essential for infectivity of RNA is associated with 5'-end; 3 '-end does not contain poly(A) or a tRNA-like structure. A subgenomic, 3'-coterminal RNA $\left(\mathrm{MW} \approx 0.38 \times 10^{6}\right)$ is also found in SBMV particles. Satellite viroid-like RNAs are associated with some members.

Protein One coat polypeptide with $\mathrm{MW} \approx 30 \times 10^{3}$.

Lipid None.

Carbohydrate None.

Antigenic properties

Efficient immunogens. Single precipitin line in gel diffusion tests. Serological relationships between strains and some members of the group.

\section{REPLICATION}

Genomic RNA remains associated with swollen virions during cell-free translation in wheat germ extract. Genome sequencing of SBMV shows four possible ORFs, with coding capacity for proteins of $\mathrm{MW} \approx 21 \times 10^{3}$ (ORF 1 , 49-603), $105 \times 10^{3}$ (ORF 2, 570-3437), $18 \times 10^{3}$ (ORF 3, 1895-2380) and $31 \times 10^{3}$ (ORF 4, 3217-4053). In vitro 
translation of full-length SBMV genomic RNA in wheat germ, or of turnip rosette virus RNA in rabbit reticulocyte lysate, yields three proteins (P1, $105 \times 10^{3} ; \mathrm{P} 2,60 \times 10^{3}$; $\left.\mathrm{P} 4,14-25 \times 10^{3}\right)$; however, coat protein $\left(\mathrm{P} 3,28 \times 10^{3}\right)$ is only translated from $0.3-0.4 \times 10^{6}$ virion-associated RNA 2 , indicating that this is a subgenomic mRNA. It is suggested that ORF 1 encodes P4(s); ORF 2 encodes P1; P2 is derived by proteolysis from P1; ORF 4 encodes P3. No protein or subgenomic mRNA has been associated with ORF 3. Genome homologies suggest mechanisms of expression of other proteins and of replication are similar to picorna- and potyviruses. Virions are found in both nuclei and cytoplasm; sometimes in crystalline arrays in the latter. The viruses do not appear to be tissue-specific.

\section{Biological Aspects}

\section{Host range}

Transmission
Each virus has relatively narrow host range.

Seed transmission in several host plants. Transmitted by beetles or a myrid in the case of velvet tobacco mottle virus. Readily transmitted mechanically.

\section{SEQUENCE Similarities WITH OTHER VIRUS GROUPS OR FAMILIES}

The predicted amino acid sequence from ORF 2 contains motifs with significant homology to (in order, $\mathrm{NH}_{2}$-end to $\mathrm{COOH}-\mathrm{end}$ ): the putative ATP-binding domain of picornaand Sindbis-like viruses; the VPg of picornaviruses; the cysteine protease of picornaviruses; the putative + strand RNA virus polymerase domain. This is similar to the core organisation of picorna-, poty-, como- and nepoviruses and puts the sobemoviruses in the picorna-like virus "superfamily". Other regions of the genome show no similarity to other viruses; this, together with the unique genome organisation, indicates that these viruses should be a distinct taxonomic group.

\section{OTHER MEMBERS}

Blueberry shoestring (204)

Cocksfoot mottle (23)

Lucerne transient streak (224)

Rice yellow mottle (149)

Solanum nodiflorum mottle (318)

Sowbane mosaic (64)

Subterranean clover mottle (329)

Turnip rosette virus (125)

Velvet tobacco mottle (317) 


\section{Possible members}

Cocksfoot mild mosaic

Cynosurus mottle

Ginger chlorotic fleck (328)

Maize chlorotic mottle (284)

Olive latent virus-1

Panicum mosaic (177)

Derivation of Name sobemo: sigla derived from the name of type member southern bean mosaic.

\section{REFERENCES}

Abad-Zapatero, C: Abdel-Meguid, S.S.; Johnson, J.E.; Leslie, A.G.W.; Rayment, I.; Rossmann, M.G.; Suck, D.; Tsukihara, T.: Structure of southern bean mosaic at $2.8 \AA$ resolution. Nature, Lond. 286:33-39 (1980).

Francki, R.I.B.; Milne, R.G.; Hatta, T.: Sobemovirus group, In Atlas of Plant Viruses, Vol. I, pp 153-169 (CRC Press, Boca Raton, Fl., 1985).

Francki, R.I.B.; Randles, J.W.; Hatta, T.; Davies, C.; Chu, P.W.G.; McLean, G.D.: Subterranean clover mottle virus: another virus from Australia with encapsidated viroidlike RNA. Plant Pathol. 32:47-59 (1983).

Ghosh, A.; Dasgupta, R.; Salerno-Rife, T.; Rutgers, T.; Kaesberg, P.: Southern bean mosaic viral RNA has a 5'-linked protein but lacks 3 ' terminal poly (A). Nuc. Acids Res. 7:2137-2146 (1979).

Goldbach, R.: Genome similarities between plant and animal RNA viruses. Microbiol. Sci. 4: 197-202 (1987).

Gorbalenya, A.E.; Koonin, E.V.; Blinov, V.M.; Donchenko, A.P.: Sobemovirus genome appears to encode a serine protease related to cysteine proteases of picornaviruses. FEBS Lett. 236: 287-290 (1988).

Hull, R.: The sobemovirus group. In Koenig, R. (ed.), The Plant Viruses, Polyhedral virions with monopartite genomes, Vol. 3, pp 113-146 (Plenum Press, New York, 1988).

Jones, A.T.; Mayo, M.A.: Satellite nature of the viroid-like RNA-2 of Solanum nodiflorum mottle virus and the ability of other plant viruses to support the replication of viroid-like RNA molecules. J. gen. Virol. 65:1713-1721 (1984).

Rossman, M.G.; Abad-Zapatero, C.; Hermodson, M.A.; Erickson, J.W.: Subunit interactions in southern bean mosaic virus. J. Mol. Biol. 166: 37-83 (1983).

Salerno-Rife, T.; Rutgers, T.; Kaesberg, P.: Translation of southern bean mosaic virus RNA in wheat embryo and rabbit reticulocyte extracts. J. Virol. 34:51-58 (1980).

Wu, S.; Rinehart, C.A.; Kaesberg, P.: Sequence and organization of southern bean mosaic virus genomic RNA. Virology 161: 73-80 (1987). 


\begin{tabular}{|lll}
\hline FAMILY NUDAURELIA $B$ VIRUS GROUP & TETRAVIRIDAE \\
\hline
\end{tabular}

Revised by J.E. Johnson

\begin{tabular}{lll}
\hline \hline GENUS & \multicolumn{1}{c}{-} & - \\
\hline TYPE SPECIES & $\begin{array}{l}\text { NUDAURELIA B VIRUS } \\
\text { (ISOLATED FROM }\end{array}$ & - \\
& NUDAURELIA CYTHEREA CAPENSIS) \\
\hline
\end{tabular}

\section{Properties of The Virus Particle}

Morphology Virions are icosahedra (probably $\mathrm{T}=4$ ).

Physicochemical $\mathrm{MW}=16.3 \times 10^{6} ; \mathrm{S}_{20 \mathrm{w}}=194-210$; buoyant density in properties $\mathrm{CsCl}=1.29 \mathrm{~g} / \mathrm{cm}^{3}$. Stable at $\mathrm{pH} 3.0$.

Nucleic acid One molecule of positive-sense ssRNA. MW $\approx 1.8 \times 10^{6}$; $10-11 \%$ of particle by weight. RNA is not polyadenylated.

Protein

Lipid

Carbohydrate

Antigenic properties

Host range
One major polypeptide of $\mathrm{MW}=60-70 \times 10^{3}$. There are small differences in MW with different isolates.

Not determined; probably none.

None detectable.

Most of the members of the group are serologically interrelated but distinguishable. The majority of the isolates were identified on the basis of their serological reaction with antiserum raised against Nudaurelia $ß$ virus.

\section{REPLICATION}

The viruses replicate primarily in the cytoplasm of gut cells of several Lepidoptera. Crystalline arrays of virus particles are often seen within cytoplasmic vesicles.

\section{Biological ASPECTS}

Natural - All species were isolated from Lepidoptera, principally from Saturniid, Limacodid and Noctuid moths. There is a considerable range of pathogenicity with different isolates. Effects of infections range from rapid death to growth retardation of larval stages. Artificial - No infections have yet been achieved in cultured invertebrate cells. 


\section{OTHER MEMBERS}

\section{Probable members}

Isolated from:

Antheraea eucalypti

Darna trima

Thosea asiona

Philosamia ricini

Trichoplusia ni

Dasychira pudibunda

\section{Possible members}

Isolated from:

Saturnia pavonia

Acherontia atropas

Setora nitens

Eucocytis meeki

Hypocrita jacobeae

Agraulis vanillae

Lymantria ninayi

Euploea corea

\section{Derivation of tetra: from Greek tettara 'four' as $\mathrm{T}=4$}

\section{Name}

\section{REFERENCES}

Finch, J.T.; Crowther, R.A.; Hendry, D.A.; Struthers, J.K.: The structure of Nudaurelia capensis $\beta$ virus; the first example of a capsid with icosahedral surface symmetry $\mathrm{T}=4$. J. gen. Virol. 24:191-200 (1974).

Greenwood, L.K.; Moore, N.F.: The Nudaurelia $\beta$ group of small RNA-containing viruses of insects: serological identification of several new isolates. J. Invertebr. Pathol. 39:407409 (1982).

King, L.A.; Merryweather, A.T.; Moore, N.F.: Proteins expressed in vitro by two members of the Nudaurelia $\beta$ family of viruses, Trichoplusia ni and Dasychira pudibunda viruses. Annales de Virologie (Inst. Pasteur) 135E:335-342 (1984).

King, L.A.; Moore, N.F.: The RNAs of two viruses of the Nudaurelia $\beta$ family share little homology and have no terminal poly (A) tracts. FEMS Microbiology Letts. 26:41-43 (1985).

Morris, T.J.; Hess, R.T.; Pinnock, D.E.: Physicochemical characterisation of a small RNA virus associated with baculovirus infection in Trichoplusia ni. Intervirol. 11:238-247 (1979).

Moore, N.F.; Reavy, B.; King, L.A.: General characteristics, gene organization and expression of small RNA viruses of insects. J. gen. Virol. 66:647-659 (1985).

Reinganum, C.; Robertson, J.S.; Tinsley, T.W.: A new group of RNA viruses from insects. J. gen. Virol. 40:195-202 (1978).

Struthers, J.K.; Hendry, D.A.: Studies of the protein and nucleic acid components of Nudaurelia capensis $\beta$ virus. J. gen. Virol. 22:355-362 (1974). 

VIRUS GROUP (352)

Revised by G.P. Martelli

\begin{tabular}{lll}
\hline TYPE MEMBER & $\begin{array}{l}\text { TOMATO BUSHY STUNT } \\
\text { VIRUS (TBSV) (69) }\end{array}$ & - \\
\hline
\end{tabular}

\section{Properties of the Virus Particle}

Morphology Isometric particles with rounded outline, $\approx 30 \mathrm{~nm}$ in diameter. 180 protein subunits are arranged in a $\mathrm{T}=3$ icosahedral lattice. In TBSV, each protein subunit folds into two distinct major globular domains $(\mathrm{P}, \mathrm{S})$, connected by a flexible hinge and a flexibly linked $\mathrm{N}$-terminal arm. Each domain P forms one-half of a dimer-clustered surface protrusion. Domain $\mathrm{S}$ forms the icosahedral shell. The inward projecting $\mathrm{N}$-terminal arms (domain $\mathrm{R}$ ) may have an RNA-binding function. Virions also encapsidate 'satellite' and subgenomic RNAs.

Physicochemical $M W \approx 8.9 \times 10^{6} ; S_{20 \mathrm{w}}=131-140$; buoyant density in properties $\mathrm{CsCl} \approx 1.35 \mathrm{~g} / \mathrm{cm}^{3}$.

Nucleic acid

One molecule of linear positive-sense ssRNA, MW $\approx 1.5$ x $10^{6}(4701-4771 \mathrm{nt}) ; 17 \%$ by weight of virus. Satellite ssRNA MW $\approx 0.21 \times 10^{6}(621 \mathrm{nt})$, defective interfering (DI) ssRNA MW $=0.14-0.24 \times 10^{6}(0.4-0.7 \mathrm{~kb})$, and two subgenomic ssRNAs MW $\approx 0.7 \times 10^{6}(2.1 \mathrm{~kb})$ and $\approx$ $0.3 \times 10^{6}(0.9 \mathrm{~kb})$ respectively are also encapsidated. 3 ends of genomic, DI and satellite RNAs do not contain poly (A) tracts; 5'-ends do not have a covalently bound VPg and are probably capped. Extensive sequence homology exists between members, in nucleotide and amino acids of both structural and putative non-structural proteins.

Protein

Lipid

Carbohydrate

Antigenic properties
One major coat polypeptide, $\mathrm{MW} \approx 43 \times 10^{3}$.

None reported.

None reported.

Good immunogens. Single precipitin line in gel-diffusion tests. Serological relationship from close to very distant among members. 


\section{REPLICATION}

Cytoplasmic, compact membranous inclusions ('multivesicular bodies') are induced by all members during early stages of infection. These bodies develop from modified peroxisomes, or more rarely, mitochondria, and contain dsRNA possibly representing RF or RI. Some members induce peripheral vesiculation of chloroplasts. Excess coat protein may accumulate in the cytoplasm in amorphous electron-dense aggregates. Virus particles are located in the cytoplasm, nuclei or with some members, in the mitochondria, sometimes in crystalline arrays. Cytoplasmic accumulations of virus particles often protrude into the vacuole.

A $4.7 \mathrm{~kb}$ genomic RNA and two 3'-coterminal RNA species of $\approx 2.1$ and $0.9 \mathrm{~kb}$ have been identified both in infected tissues and virions. The genomic RNA has four ORFs. ORF 1 encodes a protein $\mathrm{MW} \approx 33 \times 10^{3}$ and terminates with an amber stop codon. Readthrough of this stop codon would produce a polypeptide $\mathrm{MW} \approx 92 \times 10^{3}$ resulting from continuous reading of ORFs 1 and 2 . ORF3 is translated via subgenomic $\mathrm{RNA}_{1}(2.1 \mathrm{~kb})$ into a polypeptide $\mathrm{MW} \approx 41 \times 10^{3}$ (coat protein), and ORF4 via subgenomic $\operatorname{RNA}_{2}(0.9 \mathrm{~kb})$ into a polypeptide $\mathrm{MW} \approx 22 \mathrm{x}$ $10^{3}$. An additional ORF nested into ORF4 codes for a polypeptide $\mathrm{MW} \approx 19 \times 10^{3}$. The function of the $22 \mathrm{kDa}$ and $19 \mathrm{kDa}$ proteins is unknown, whereas the $92 \mathrm{kDa}$ protein may be a part of the viral replicase. Three virusspecific dsRNAs corresponding to genomic and subgenomic RNAs have been detected in infected tissues. Satellite RNA has no detectable messenger activity and is present in linear monomers and dimers in single- and double-stranded forms. DI RNAs occur both as singleand double-stranded forms.

\section{Biological ASPECTS}

Host range

Transmission
Wide among angiosperms.

Readily transmitted by mechanical inoculation. Seed transmission is reported for some members. Acquisition through soil is possible. Cucumber necrosis virus is transmitted by the chytrid fungus Olpidium radicale.

\section{SIMILARITIES WITH OTHER VIRUS GROUPS}

Tombusviruses share with members of the carmovirus group, significant structural similarities in the capsid 
protein with respect to polypeptide folding topology and subunit interactions. Physico-chemical properties are also similar but the genome organization is quite different.

\section{OTHER MEMBERS}

Artichoke mottle crinkle (69)

Carnation Italian ringspot (69)

Cucumber necrosis (82)

Cymbidium ringspot (178)

Eggplant mottled crinkle

Grapevine Algerian latent

Moroccan pepper

Lato river

Neckar river

Pelargonium leaf curl (69)

Petunia asteroid mosaic (69)

Derivation of

Name

tombus: sigla from tomato bushy stunt.

\section{REFERENCES}

Burgyan, J.; Grieco, F.; Russo, M.: A defective interfering RNA molecule in cymbidium ringspot virus infections. J. gen. Virol. 70: 235-239 (1989).

Burgyan, J.; Nagy, P.D.; Russo, M.: Synthesis of infectious RNA from full-length cloned cDNA to RNA of cymbidium ringspot tombusvirus. J. Gen. Virol. 71: 1857-1860 (1990).

Burgyan, J.; Russo, M.; Gallitelli, D.: Translation of cymbidium ringspot virus RNA in cowpea protoplasts and rabbit reticulocyte lysates. J. gen. Virol. 67:1149-1160 (1986).

Gallitelli, D.; Russo, M.: Some properties of Moroccan pepper virus and tombusvirus Neckar. J. Phytopathol. 119:106-110 (1987).

Gallitelli, D.; Hull, R.: Characterization of satellite RNAs associated with tomato bushy stunt virus and five other definitive tombusviruses. J. gen. Virol. 66:1533-1543 (1985).

Grieco, F.; Burgyan, J.; Russo, M.: The nucleotide sequence of cymbidium ringspot virus RNA. Nuc. Acids Res. 17: 6383 (1989).

Hearne, P.Q.; Knorr, D.A.; Hillman, B.I.; Morris, T.J.: The complete genome structure and synthesis of infectious RNA from clones of tomato bushy stunt virus. Virology 177: 141-151 (1990).

Hillman, B.I.; Hearne, P.; Rochon, D.; Morris, T.J.: Organization of tomato bushy stunt virus genome: Characterization of the coat protein gene and the 3 ' terminus. Virology 169: 42-50 (1989).

Koenig, R.; Gibbs, A.: Serological relationships among tombusviruses. J. gen. Virol. 67:7582 (1986).

Makkouk, K.M.; Koenig, R.; Lesemann, D.-E.: Characterization of a tombusvirus isolated from eggplant. Phytopathology 71:572-577 (1981).

Martelli, G.P.: Tombusviruses. In Kurstak, E. (ed.), Handbook of Plant Virus Infections and Comparative Diagnosis, pp. 61-90. (Elsevier/North Holland, Amsterdam, 1981). 
Martelli, G.P.; Gallitelli, D.; Russo, M.: Tombusviruses. In Koenig, R. (ed.), The Plant Viruses, Polyhedral Virions With Monopartite RNA Genomes, Vol. 3, pp. 13-72. (Plenum Press, New York, 1988).

Olson, A.J.; Bricogne, G.; Harrison, S.C.: Structure of tomato bushy stunt virus. IV. The virus particle at $2.9 \AA$ resolution. J. Mol. Biol. 171:61-93 (1983).

Rochon, D.M.; Tremaine, J.H.: Cucumber necrosis virus is a member of the tombusvirus group. J. gen. Virol. 69:395-400 (1988).

Rochon, D.M.; Tremaine, J.H.: Complete nucleotide sequence of the cucumber necrosis virus genome. Virology 169: 251-259 (1989).

Rubino, L.; Burgyan, J.; Grieco, F.; Russo, M.: Sequence analysis of cymbidium ringspot virus satellite and defective interfering RNAs. J. gen. Virol. 71: 1655-1660 (1990).

Russo, M.; Di Franco, A.; Martelli, G.P.: Cytopathology in the identification and classification of tombusviruses. Intervirology 28: 134-143 (1990).

Russo, M.; Burgyan, J.; Carrington, J.C.; Hillman, B.l.; Morris, T.J.: Complementary DNA cloning and characterization of cymbidium ringspot virus RNA. J. gen. Virol. 69:401406 (1988). 


\begin{tabular}{|lll|}
\hline GROUP & TURNIP YELLOW MOSAIC & TYMOVIRUS \\
& VIRUS GROUP (214) & \\
\hline
\end{tabular}

Revised by R. Koenig

\begin{tabular}{lll}
\hline TYPE MEMBER & TURNIP YELLOW MOSAIC & - \\
& VIRUS (TYMV) $(2 ; 230)$ & \\
\hline
\end{tabular}

\section{Properties of The Virus Particle}

Morphology

Particles are $T=3$ icosahedral structures, $\approx 29 \mathrm{~nm}$ in diameter. They are stabilized by protein-protein interactions of the 180 subunits, which are clustered into 12 pentamers and 20 hexamers.

Physicochemical Two major classes of stable particles (B and T) with MWs properties of 5.6 and $3.6 \times 10^{6}$; buoyant densities in $\mathrm{CsCl} \approx 1.42$ and $1.29 \mathrm{~g} / \mathrm{cm}^{3}$, and $S_{20 \mathrm{w}}=115$ and 54 , respectively. Only the B component containing the genome RNA is infectious. Partial specific volume $=0.661$. The isoelectric point of TYMV is $\mathrm{pH} 3.75$; those of other members cover a wide $\mathrm{pH}$ range. Virus is stable at neutral $\mathrm{pH}$. Several minor nucleoproteins can be isolated with densities intermediate between those of the two major particle types. For TYMV, these contain subgenomic coat protein mRNA and less than full-length pieces of the genome RNA.

Nucleic acid One molecule of linear positive-sense ssRNA containing 3 ORFs; $\mathrm{MW} \approx 2 \times 10^{6}$, accounting for $\approx 35 \%$ of the weight of the B component. The 5' terminus of TYMV RNA has the sequence $m^{7} \mathrm{G}^{5^{\prime}} \mathrm{ppp}^{5} \mathrm{Gp} .$. ; the $3^{1}$ terminus has a tRNA-like structure which accepts valine. Small amounts of subgenomic coat protein mRNA (695 nt; MW $\approx 0.25 \mathrm{x}$ $10^{6}$ ) are found in several classes of virus particles. Both RNAs have a high content of cytidylic acid (32-41\%). Particles of some members may also contain small amounts of transfer RNAs of plant origin. The RNAs of several tymoviruses have been sequenced.

Protein

Lipid

Carbohydrate

Antigenic properties
One coat protein $\mathrm{MW} \approx 20 \times 10^{3}$. 180 molecules per particle.

None.

None.

Serological relationships between members of the group range from very close, to distant, to not detectable. 


\section{REPLICATION}

Genomic RNA of TYMV is translated in vitro into 2 proteins of 150 and $195 \times 10^{3}$, the latter by read through of the $150 \times 10^{3}$ gene. A subgenomic RNA (695 nt) corresponding to the $3^{\prime}$ region of the genomic RNA is translated in vitro into coat protein. Post-translational processing of the $195 \times 10^{3}$ protein in vitro has been reported. Tymoviruses induce at the periphery of the chloroplasts small flask-shaped double-membrane bounded vesicles which contain membrane-bound viral polymerase. They are probably the main site of production of viral positive-sense RNA. Pentamers and hexamers of the protein are probably produced in the cytoplasm, and virions assembled at the necks of the vesicles. Empty protein shells accumulate in nuclei. Most members cause clumping of chloroplasts in infected cells.

\section{Biological Aspects}

\section{Host range}

Transmission
Possibly restricted to dicotyledonous hosts. Individual viruses often have narrow host range.

By beetles and mechanical inoculation.

\section{OTHER MEMBERS}

Belladonna mottle (52)

Cacao yellow mosaic (11)

Clitoria yellow vein (171)

Desmodium yellow mottle (168)

Dulcamara mottle

Eggplant mosaic (124)

Erysimum latent(222)

Kennedya yellow mosaic (193)

Okra mosaic (128)

Ononis yellow mosaic

Passion fruit yellow mosaic

Peanut yellow mosaic

Physalis mosaic

Plantago mottle

Scrophularia mottle (113)

Voandzeia necrotic mosaic (279)

Wild cucumber mosaic (105)

Possible member

Poinsettia mosaic virus (311) 
Derivation of tymo: sigla from turnip yellow mosaic virus

Name

\section{REFERENCES}

Crestani, O.A.; Kitajima, E.W.; Lin, M.T.; Marinho, V.L.A.: Passion fruit yellow mosaic virus, a new tymovirus found in Brazil. Phytopathology 76:951-955 (1986).

Fauquet, C.; Monsarrat, A.; Thouvenel, J.-C.: Voandzeia necrotic mosaic virus, a new tymovirus. 5th Int'1 Congr. Virology (Strasbourg) Abstract. P23/03 p. 237 (1981).

Francki, R.I.B.; Milne, R.G.; Hatta, T.: Tymovirus group, In Atlas of Plant Viruses, Vol. I, pp 117-136 (CRC Press, Boca Raton, Fl., 1985).

Fulton, R.W.; Fulton, J.L.: Characterization of a tymo-like virus common in poinsettia. Phytopathology 70:321-324 (1980).

Hirth, L.; Givord, L.: Tymoviruses, In Koenig, R. (ed.), The Plant Viruses, Polyhedral Plant Virions With Monopartite RNA Genomes, Vol. 3, pp. 163-212 (Plenum Press, New York, 1988).

Koenig, R.: A loop-structure in the serological classification system of tymoviruses. Virology $72: 1-5(1976)$.

Koenig, R.; Lesemann, D.-E.: Tymoviruses; In Kurstak, E. (ed.), Handbook of Plant Virus Infections and Comparative Diagnosis, pp. 33-60. (Elsevier/North Holland, Amsterdam, 1981).

Lana, A.F.: Properties of a virus occurring in Arachis hypogea in Nigeria. Phytopath. Z. 97:169-178 (1980).

Lesemann, D.-E.: Virus group-specific and virus-specific cytological alterations induced by members of the tymovirus group. Phytopath. Z. 90:315-336 (1977).

Osorio-Keese, M.E.; Keese, P.; Gibbs, A.J.: Nucleotide sequence of the genome of eggplant mosaic tymovirus. Virology 172: 547-554 (1989).

Szybiak, U.; Bouley, J.P.; Fritsch, C.: Evidence for the existence of a coat protein messenger RNA associated with the top component of each of three tymoviruses. Nuc. Acids Res. 5:1821-1831 (1978).

Zagorski, W.; Morch, M.-D.; Haenni, A.-L.: Comparison of three different cell-free systems for turnip yellow mosaic virus RNA translation. Biochimie 65:127-133 (1983). 
GROUP

APPLE STEM GROOVING

CAPILLOVIRUS VIRUS GROUP

Revised by M. Bar-Joseph \& G.P. Martelli

\begin{tabular}{lll}
\hline TYPE MEMBER & APPLE STEM GROOVING & - \\
& VIRUS (ASGV) (31) & \\
\hline
\end{tabular}

\section{Properties of The Virus Particle}

Morphology Flexuous filamentous particles $\approx 640 \times 12 \mathrm{~nm}$, with obvious cross-banding (helical symmetry).

Physicochemical $S_{20 w} \approx 100 S$.

properties

Nucleic acid One molecule of linear, plus sense ssRNA, MW $\approx 2.5 \mathrm{x}$ $10^{6} ; \approx 5 \%$ by weight of virion. RNA is polyadenylated at 3 '-end.

Protein Single polypeptide, MW $\approx 27 \times 10^{3}$.

Lipid None reported

Carbohydrate None reported

Antigenic properties

Moderately immunogenic; serological relationship between members.

\section{REPLICATION}

Not studied.

\section{Biological ASPECTS}

Host range Natural host range restricted, experimental host range moderate.

Transmission Vector unknown. Transmitted through seed and by mechanical inoculation of sap.

\section{OTHER MEMBERS}

Potato virus T (187)

\section{Possible members}

Lilac chlorotic leaf spot (202)

Nandina stem pitting 
Derivation of capillo: from Latin capillus, a hair

Name

\section{REFERENCES}

Ahmed, N.A.; Christie, S.R.; Zettler, F.W.: Identification and partial characterization of a closterovirus infecting Nandina domestica.. Phytopathology 73:470-475 (1983).

Conti, M.; Milne, R.G.; Luisoni, E.; Boccardo, G.: A closterovirus from a stem-pittingdiseased grapevine. Phytopathology 70:394-399 (1980).

de Sequeira, O.A.; Lister, R.M.: Purification and relationships of some filamentous viruses from apple. Phytopathology 59:1740-1749 (1969).

Salazar, L.F.; Harrison, B.D.: Host range, purification and properties of potato virus T. Ann. appl. Biol. 89:223-235 (1978).

Salazar, L.F.; Hutcheson, A.M.; Tollin, P.; Wilson, H.R.: Optical diffraction studies of particles of potato virus T. J. gen. Virol. 39:333-342 (1978).

Yoshikawa, N.; Takahashi, T.: Properties of RNAs and proteins of apple stem grooving and apple chlorotic leaf spot viruses. J. gen. Virol. 69:241-245 (1988). 

VIRUS GROUP (259)

Revised by A.A. Brunt

\begin{tabular}{lll}
\hline TYPE MEMBER & $\begin{array}{l}\text { CARNATION LATENT } \\
\text { VIRUS (CLV) (61) }\end{array}$ & - \\
\hline
\end{tabular}

\section{Properties of the Virus Particle}

Morphology

Slightly flexuous filaments $610-700 \mathrm{~nm}$ long, $12-15 \mathrm{~nm}$ in diameter with helical symmetry and pitch $\approx 3.4 \mathrm{~nm}$.

Physicochemical $\quad M W \approx 60 \times 10^{6} ; S_{20} w=147-176 S$; buoyant density in properties $\mathrm{CsCl} \approx 1.3 \mathrm{~g} / \mathrm{cm}^{3}$.

Nucleic acid

One molecule of linear positive-sense ssRNA; MW $=2.4$ $2.8 \times 10^{6} ; 5-6 \%$ by weight of the virus. Those of some members have been partially sequenced; the RNA molecules have 3 ' poly (A) tracks.

Protein

Lipid

Carbohydrate

Antigenic properties
One coat polypeptide, $\mathrm{MW}=31-34 \times 10^{3}$.

None reported.

None reported.

Efficient immunogens. Serological relationship among some members.

\section{REPLICATION}

Particles are found occasionally scattered throughout cytoplasm but more usually occur in bundle-shaped aggregates associated with tonoplasts, cell walls or chloroplast membranes. Cytoplasm may also contain inclusions consisting of endoplasmic reticulum and some unaggregated particles.

Viral RNA has at least 6 open reading frames which have been translated in vitro into proteins of $\mathrm{MW} \approx 10 \mathrm{kDa}$, $33 \mathrm{kDa}, 7 \mathrm{kDa}, 12 \mathrm{kDa}, 25 \mathrm{kDa}$ and $41-45 \mathrm{kDa}$. The $33 \mathrm{kDa}$ product is the coat protein and the $41-45 \mathrm{kDa}$ protein is possibly a viral replicase; the function of the other proteins has yet to be determined. The deduced amino acid sequences of the central regions of some coat proteins show close homology with that of potato virus X. The putative carlavirus replicase and the $7 \mathrm{kDa}, 12 \mathrm{kDa}$ and $25 \mathrm{kDa}$ proteins also show some homology with proteins of 
similar sizes induced by potexviruses. The coat protein gene of potato virus $S$, like that of potexviruses, is located on a subgenomic RNA of $1.3 \mathrm{~kb}$ which is possibly encapsidated in filamentous particles $100-200 \mathrm{~nm}$ long. A single dsRNA $\left(M \approx 5.0-5.5 \times 10^{6}\right)$ corresponding to the viral ssRNA has been isolated from infected plants.

\section{Biological ASPECTS}

\section{Host range}

Transmission
Individual viruses have rather narrow host ranges.

Often by aphids in a non-persistent manner; two possible members are transmitted by whiteflies (Bemisia tabaci). Two viruses infecting legumes are seedborne. Experimentally transmitted by mechanical inoculation.

\section{OTHer Members}

Cactus 2

Caper latent

Chrysanthemum B (110)

Dandelion latent

Elderberry carla (= Elderberry A) (263)

Helenium S (265)

Honeysuckle latent (289)

Hop (American) latent (262)

Hop latent (261)

Hop mosaic (241)

Hydrangea latent

Kalanchoe latent

Lilac mottle

Lily symptomless (96)

Mulberry latent

Muskmelon vein necrosis

Narcissus latent (= gladiolus ringspot) (170)

Nerine latent (= hippeastrum latent)

Passiflora latent

Pea streak (112) (alfalfa latent (211))

Poplar mosaic (75)

Potato M (87)

Potato S (= pepino latent) (60)

Red clover vein mosaic (22)

Shallot latent (250)

Strawberry pseudo mild yellow edge

\section{Possible members}

Aphid-borne:

Alstroemeria carlavirus

Arracacha latent 


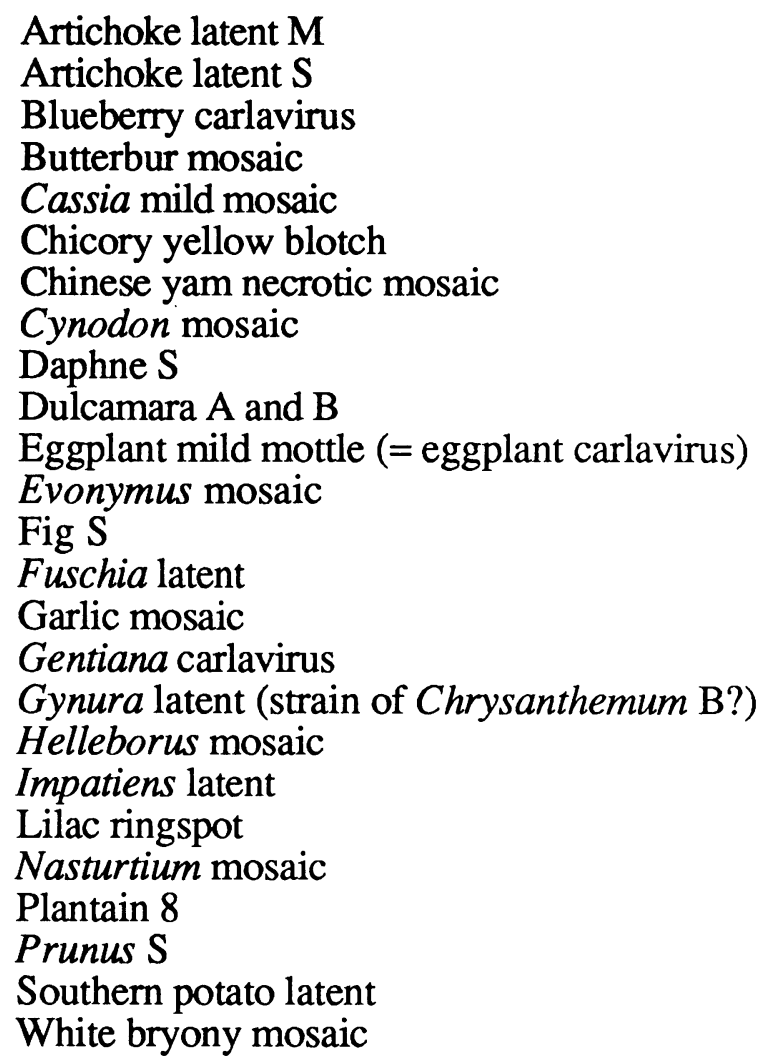

Whitefly-borne:

Cassava brown streak

Cowpea mild mottle (= Psophocarpus necrotic mosaic, groundnut crinkle, tomato pale chlorosis, Voandzeia mosaic) (140)

Derivation of carla: sigla from carnation latent Name

\section{REFERENCES}

Adams, A.N.; Barbara, D.J.: Host range, purification and some properties of two carlaviruses from hop (Humulus lupulus): hop latent and American hop latent. Ann. appl. Biol. 101:483-494 (1982).

Allan, T.C.; McMorran, J.P.; Lawson, R.H.: Detection and identification of viruses in hydrangea. Acta Hort. 164:85-99 (1985).

Antignus, Y.; Cohen, S.: Purification and some properties of a new strain of cowpea mild mottle virus in Israel. Ann. appl. Biol. 110: 563-569 (1987).

Di Franco, A.; Gallitelli, D.; Vovlas, C.; Martelli, G.P.: Partial characterization of artichoke virus M. J. Phytopathology 127: 265-273 (1989).

Fauquet, C.; Thouvenel, J.-C.: Maladies Virales des Plantes en Côte d'Ivoire. (Éditions de l'ORSTOM, Bondy, France, 1987). 
Foster, G.D.; Mills, P.R.: Evidence for the role of subgenomic RNAs in the production of potato virus S coat protein during in vitro translation. J. gen. Virol. 71: 1247-1249 (1990).

Gallitelli, D.; di Franco, A.: Characterization of caper latent virus. J. Phytopath. 119:97-105 (1987).

Hammond, J.: Viruses occurring in Plantago species in England. Plant Path. 30:237-243 (1981).

Hampton, R.O.: Evidence suggesting identity between alfalfa latent and pea streak viruses. Phytopathology 71:223 (1981).

Hearon, S.S.: A carlavirus from Kalanchoe blossfeldiana. Phytopathology 72:838-844 (1982).

Johns, L.J.: Purification and partial characterization of a carlavirus from Taraxacum officinale. Phytopathology 72:1239-1242 (1982).

Khalil, J.A.; Nelson, M.R.; Wheeler, R.E.: Host range, purification, serology, and properties of a carlavirus from eggplant. Phytopathology 72: 1064-1068 (1982).

Koenig, R.: Recently discovered virus or virus-like diseases of ornamentals and their epidemiological significance. Acta Hort. 164:21-31 (1985).

Mackenzie, D.J.; Tremaine, J.H.; Stace-Smith, R.: Organization and interviral homologies of the 3'-terminal portion of potato virus S RNA. J. gen. Virol. 70: 1053-1063 (1989).

Memelink, J.; van der Vlugt, C.I.M.; Linthorst, H.J.M.; Derks, A.F.L.M.; Asjes, C.J.; Bol, J.F.: Homologies between the genomes of a carlavirus (lily symptomless virus) and a potexvirus (lily virus X) from lily plants. J. gen. Virol. 71: 917-924 (1990).

Milne, R.G.: Taxonomy of the rod-shaped filamentous viruses. In, Milne, R.G. (ed.), The Plant Viruses, The filamentous plant viruses, Vol. 4, pp. 3-50. (Plenum Press, New York, 1988).

Monis, J.; de Zoeten, G.A.: Characterization and translation studies of potato virus S RNA. Phytopathology 80: 441-445 (1990).

Monis, J.; de Zoeten, G.A.: Molecular cloning and physical mapping of potato virus $S$ complementary DNA. Phytopathology 80: 446-450 (1990).

Phillips, Sue; Brunt, A.A.: Four viruses of Alstroemeria in Britain. Acta Hort. 177:227-233 (1986).

Plese, N.; Wrischer, M.: Filamentous virus associated with mosaic of Euonymus japonica. Acta Bot. Croat. 40: 31 (1981).

Rupasov, V.V.; Morozov, S.Yu; Kanyuka, K.V.; Zavriev, S.K.: Partial nucleotide sequence of potato virus M RNA shows similarities to potexviruses in gene arrangement and the encoded amino acid sequences. J. gen. Virol. 70: 1861-1869 (1989).

Tavantzis, S.M.: Physicochemical properties of potato virus M. Virology 133: 427-430 (1984).

Valverde, R.A.; Dodds, J.A.; Heick, J.A.: Double-stranded ribonucleic acid from plants infected with viruses having elongated particles and undivided genomes. Phytopathology 76 : 459-465 (1986).

Wetter, C.; Milne, R.G.: Carlaviruses; In Kurstak, E. (ed.), Handbook of Plant Virus Infections and Comparative Diagnosis, pp. 695-730. (Elsevier/North Holland, Amsterdam, 1981). 
Revised G.P. Martelli \& M. Bar-Joseph

\begin{tabular}{l} 
TYPE MEMBER \\
\hline Morphology \\
$\begin{array}{l}\text { Physicochemical } \\
\text { properties }\end{array}$
\end{tabular}

Nucleic acid

Protein

\section{Lipid}

Carbohydrate

Antigenic properties

\section{SUGAR BEET YELLOWS VIRUS (SBYV)(13)}

\section{Properties of The Virus Particle}

Very flexuous rods $700-2,000 \mathrm{~nm}$ long $12 \mathrm{~nm}$ wide; helical symmetry with pitch $=3.4-3.7 \mathrm{~nm}$.

$\mathrm{S}_{20 \mathrm{w}}=96-130$; buoyant density in $\mathrm{CsCl}=1.30-1.34$ $\mathrm{g} / \mathrm{cm}^{3}$. Particles unstable in high salt concentrations.

One molecule of linear positive-sense ssRNA, MW $=2.5$ $6.5 \times 10^{6} ; \approx 5 \%$ by weight of virus particle.

One coat polypeptide, $\mathrm{MW}=23-43 \times 10^{3}$.

None reported.

None reported.

Moderately immunogenic; serological relationships between some members.

\section{REPLICATION}

Particles of most members aggregate in fibrous or crossbanded masses in phloem cells. The complete nucleotide sequence (7555 nt) and genome organization of the possible member apple chlorotic leafspot virus (ACLSV) has been determined as well as the $3^{\prime}$ terminal half (6746 nt) of the genome of the type member SBYV. Remarkable differences exist in that: (a) the 3' end of ACLSV is polyadenilated whereas that of SBYV is not; (b) ACLSV genome has three ORFs with the coat protein cistron coterminal with the $3^{\prime}$ end, whereas SBYV genome has as least eight ORFs with the coat protein cistron separated from the 3' end by two downstream ORFs. Multiple dsRNAs of lower MW than those of genomic ds-RNAs have been extracted from plants infected by some members, suggesting that these ds-RNAs may be templates for transcription of subgenomic m-RNAs together with membranous vesicles containing dsRNA-like fibrils (SBYV-like vesicles). Several other members do not 
induce formation of SBYV-like vesicles but their particles also aggregate in bundles in parenchyma cells and sieve tubes. Particles are rarely seen within nuclei.

\section{BiOLOGICAL ASPECTS}

\section{Host range Moderately wide for individual viruses.}

Transmission Few members transmissible with difficulty by mechanical inoculation. Some members transmitted by aphids, pseudococcid mealybugs (Planococcus and Pseudococcus) or whiteflies (Bemisia, Trialeurodes) in a semi-persistent manner.

\section{OTHER MEMBERS}

Beet yellow stunt (207)

Burdock yellows

Carnation necrotic fleck (136)

Carrot yellow leaf

Citrus tristeza (33)

Clover yellows

Festuca necrosis

Grapevine virus A

Wheat yellow leaf (157)

\section{Possible members}

Apple chlorotic leafspot (30)

Beet pseudo yellows

Cucumber yellows

Diodia yellow vein

Grapevine leafroll-associated I

Grapevine leafroll-associated II

Grapevine leafroll-associated III

Grapevine leafroll-associated IV

Grapevine leafroll-associated V

Heracleum latent (228)

Lettuce infectious yellows

Pineapple mealybug wilt-associated

Derivation of Name clostero: from Greek kloster, 'spindle, thread', from appearance of very long rods 


\section{REFERENCES}

Agranovsky, A.A.; Boyke, V.F.; Karasev, A.V.; Lunina, N.A.; Koonin, E.V.; Dolja, V.V.: Nucleotide sequence of the 3' terminal half of beet yellows closterovirus RNA genome: unique arrangement of eight virus genes. J. gen. Virol. (1990) (in press).

Bar-Joseph, M.: Garnsey, S.M.; Gonsalves, D.: The closteroviruses: a distinct group of elongated plant viruses. Adv. Virus Res. 25:93-168 (1979).

Boccardo, G.; D'Aquilio, M.: The protein and nucleic acid of a closterovirus isolated from a grapevine with stem-pitting symptoms. J. gen. Virol. 53:179-182 (1981).

Dodds, J.A.; Bar-Joseph, M.: Double-stranded RNA from plants infected with closteroviruses. Phytopathology 73:419-423 (1983).

Duffus, J.E.: Whitefly transmission of plant viruses; In Harris, K.F. (ed.), Current Topics in Vector Research, vol. 4, pp. 73-91 (Springer, Berlin,Heidelberg, New York, Tokyo, 1987).

German, S.; Candresse, T.; Lanneau, M.; Huet, J.C.; Pernollet, J.C.; Dunez, J.: Nucleotide sequence and genomic organization of apple chlorotic leafspot closterovirus. Virology 179:104-112 (1990).

Gunasinghe, U.B.; German, T.L.: Purification and partial characterization of a virus from pineapply. Phytopathology 79: 1337-1341 (1989).

Hu, J.S.; Gonslaves, D.; Teliz, D.: Characterization of closterovirus-like particles associated with grapevine leafroll disease. J. Phytopathol. 128: 1-14 (1990).

Lesemann, D.E.: Cytopathology: In Milne, R.G. (ed.), The Plant Viruses, The filamentous plant viruses, Vol. 4, pp. 179-235 (Plenum Press, New York, 1988).

Lister, R.M.; Bar-Joseph, M.: Closteroviruses; In Kurstak, E. (ed.), Handbook of Plant Virus Infections and Comparative Diagnosis, pp. 809-844 (Elsevier/North Holland, Amsterdam, 1981).

Rosciglione, B.; Castellano, M.A.; Martelli, G.P.; Savino, V.; Cannizzaro, G.: Mealybug transmission of grapevine virus A. Vitis 22: 331-347. 


\begin{tabular}{|lll|}
\hline GROUP & $\begin{array}{l}\text { POTATO VIRUS X } \\
\text { GROUP }(200)\end{array}$ & POTEXVIRUS \\
\hline
\end{tabular}

Revised by R. Koenig

\begin{tabular}{lll}
\hline TYPE MEMBER & POTATO VIRUS X (PVX)(4) & - \\
\hline
\end{tabular}

Morphology

Physicochemical properties

Nucleic acid

Protein

Lipid

Carbohydrate

Antigenic properties

Host range

Transmission

\section{Properties of the Virus Particle}

Flexuous filaments $470-580 \mathrm{~nm}$ long and $13 \mathrm{~nm}$ wide, with helical symmetry and pitch $\approx 3.4 \mathrm{~nm}$.

$\mathrm{MW} \approx 35 \times 10^{6} ; \mathrm{S}_{20 \mathrm{w}}=115-130 ;$ density in $\mathrm{CsCl} \approx 1.31$ $\mathrm{g} / \mathrm{cm}^{3}$; particles stable.

One molecule of linear positive-sense ssRNA with 5 ORFs; $\mathrm{MW} \approx 2.1 \times 10^{6}, \approx 6 \%$ by weight of the particle. $5^{\prime}$ terminus has sequence $\mathrm{m}^{7} \mathrm{G}^{5} \mathrm{pppGpA}$. Poly(A) at $3^{\prime}$ terminus; RNAs of PVX and white clover mosaic virus have been sequenced; RNA contains high A content $(\approx$ $30 \%$ ).

One coat polypeptide, $\mathrm{MW} \approx 18-23 \times 10^{3}$. In some viruses, protein can become partially degraded by enzymes in plant sap.

None reported.

None reported.

Efficient immunogens; serological relationship between some members.

\section{REPLICATION}

Fibrous cytoplasmic inclusions composed of virus particles, often banded; some members induce nuclear inclusions of different composition. Intact genomic RNA is translated into high-molecular-weight proteins, the viral coat protein from a subgenomic RNA.

\section{Biological ASPECtS}

Narrow for individual viruses.

Readily transmissible mechanically, experimentally, and by contact between plants. No known vectors. 


\section{OTHER MEMBERS}

\section{Asparagus III}

Cactus X (58)

Clover yellow mosaic (111)

Commelina X

Cymbidium mosaic (27)

Foxtail mosaic (264)

Hydrangea ringspot (114)

Lily X

Narcissus mosaic (45)

Nerine X

Papaya mosaic (56)

Pepino mosaic

Plantago severe mottle

Plantain X (266)

Tulip X (276)

Viola mottle (247)

White clover mosaic (41)

\section{Possible members}

Artichoke curly dwarf

Bamboo mosaic

Barley B-1

Boletus

Cassava common mosaic (90)

Centrosema mosaic

Daphne X (195)

Dioscorea latent

Lychnis potexvirus

Malva veinal necrosis

Nandina mosaic

Negro coffee mosaic

Parsley 5

Parsnip 5

Parsnip 3

Potato aucuba mosaic (98)

Rhododendron necrotic ringspot

Rhubarb 1

Smithiantha potexvirus

Wineberry latent

Zygocactus

\section{Derivation of potex: sigla from potato $X$}




\section{REFERENCES}

Forster, R.L.S.; Bevan, M.W.; Harbison, S.-A.; Gardner, R.C.: The complete nucleotide sequence of the potexvirus white clover mosaic virus. Nuc. Acids Res. 16: 291-303 (1988).

Fujisawa, I.: Asparagus virus III: a new member of the potexvirus group from asparagus. Ann. Phytopath. Soc. Japan 52:193-200 (1986).

Hammond, J.; Hull, R.: Plantain virus X: a new potexvirus from Plantago lanceolata. J. gen. Virol. 54:75-90 (1981).

Huisman, M.J.; Linthorst, H.J.M.; Bol, J.F.; Cornelissen, B.J.C.: The complete nucleotide sequence of potato virus $\mathrm{X}$ and its homologies at the amino acid level with various plusstranded RNA viruses. J. gen. Virol. 69: 1789-1798 (1988).

Koenig, R.: Recently discovered viruses or virus-like diseases of ornamentals and their epidemiological significance. Acta Hort. 166:21-31 (1985).

Mowat, W.P.: Pathology and properties of tulip virus X, a new potexvirus. Ann. appl. Biol. 101:51-63 (1982).

Phillips, S.; Brunt, A.A.; Beczner, L.: The recognition of boussingaultia mosaic virus as a strain of papaya mosaic virus. Acta Hort. 164:379-383 (1984).

Phillips, S.; Piggott, J.D.A.; Brunt, A.A.: Further evidence that dioscorea latent virus is a potexvirus. Ann. appl. Biol. 109:137-145 (1986).

Purcifull, D.E.; Edwardson, J.R.: Potexviruses; In Kurstak, E. (ed.), Handbook of Plant Virus Infections and Comparative Diagnosis, pp. 627-693. (Elsevier/North Holland, Amsterdam, 1981).

Rowhani, A.; Peterson, J.F.: Characterization of a flexuous rod-shaped virus from Plantago. Can. J. Plant Pathol. 2:12-18 (1980).

Stone, O.M.: Two new potexviruses from monocotyledons. Acta Hort. 110:59-63 (1980).

Wodnar-Filipowicz, A.; Skrzeczkowski, L.J.; Filipowicz, W.: Translation of potato virus X RNA into high molecular weight proteins. FEBS Lett. 109:151-155 (1980).

Zettler, F.W.; Abo El-Nil, M.M.; Hiebert, E.; Christie, R.G.; Marciel-Zambolin, E.: A potexvirus infecting Nandina domestica 'Harbor Dwarf. Acta Hort. 110:71-80 (1980).

Zettler, F.W.; Nagel, J.: Infection of cultivated gesneriads by two strains of tobacco mosaic virus. Plant Dis. 67:1123-1125 (1983). 


\begin{tabular}{|lll}
\hline GROUP & POTATO VIRUS Y GROUP (245) & POTYVIRUS \\
\hline
\end{tabular}

Revised by O.W. Barnett

\begin{tabular}{lll}
\hline TYPE MEMBER & $\begin{array}{l}\text { POTATO VIRUS Y (PVY) } \\
(37 ; 242)\end{array}$ & - \\
\hline
\end{tabular}

Properties of the Virus Particle

Morphology

Flexuous filaments $680-900 \mathrm{~nm}$ long and $11 \mathrm{~nm}$ wide, with helical symmetry and pitch $\approx 3.4 \mathrm{~nm}$. Particles of some viruses longer in presence of divalent cations than in presence of EDTA.

Physicochemical $S_{20 w}=150-160$; density in $\mathrm{CsCl} \approx 1.31 \mathrm{~g} / \mathrm{cm}^{3}$. properties

Nucleic acid

One molecule of linear positive-sense ssRNA. MW $=3.0$ $3.5 \times 10^{6}(8.5-10 \mathrm{~kb}) ; \approx 5 \%$ by weight of particle. RNA molecules have poly(A) tracts at their 3' ends. A genomelinked protein which is not essential for infectivity is covalently linked near the 5 ' terminus.

\section{Protein}

\section{Lipid}

Carbohydrate

Antigenic properties
One coat polypeptide, $\mathrm{MW}=32-36 \times 10^{3}$. Coat protein of type member contains 267 amino acids.

None reported.

None reported.

Moderately immunogenic; serological relationships among many members. One monoclonal antibody reacts with most aphid transmitted potyviruses.

\section{REPLICATION}

Characteristic cylindrical or conical inclusions, appearing as pinwheels when seen in transverse section, are induced in the cytoplasm; protein of inclusions ( $\mathrm{MW}=70 \times 10^{3}$ ) serologically unrelated to virus coat protein but specified by viral genome. Some members also induce nuclear inclusions. RNA from some members has been translated in vitro into proteins of $\mathrm{MW}$ corresponding to more than $90 \%$ of the genome coding potential. Genome is probably translated into a large poly-protein which is processed into several functional proteins of lower MW. 


\section{Biological ASPECTS}

Host range

Transmission
Narrow for many individual viruses but other viruses infect species in up to 30 families.

Transmitted by aphids in a non-persistent manner. Others, included as possible members of the group, are transmissible by whiteflies, mites or fungi. Transmissible experimentally by mechanical inoculation.

\section{SIMILARITIES WITH OTHER VIRUS GROUPS OR FAMILIES}

Some potyviruses share significant similarities with como-, nepo- and picornaviruses, e.g. genome organization, VPg at 5'-end and poly $\mathrm{A}$ at 3 '-end of the genomes, posttranslational processing of polyproteins and similar consensus sequences among non-structural proteins.

\section{OTHER MEMBERS}

Alstroemeria mosaic

Amaranthus leaf mottle

Araujia mosaic

Artichoke latent

Asparagus 1

Bean common mosaic $(73,337)$

Bean yellow mosaic

$$
\text { (= pea mosaic, crocus tomasinianus) (40) }
$$

Beet mosaic (53)

Bidens mottle (161)

Blackeye cowpea mosaic (305)

Cardamom mosaic

Carnation vein mottle (78)

Carrot thin leaf (218)

Celery mosaic (50)

Clover yellow vein (= pea necrosis) (131)

Cocksfoot streak (59)

Colombian datura

Commelina mosaic

Cowpea aphid-borne mosaic (= Azuki bean mosaic) (134)

Cowpea green vein banding

Dasheen mosaic (191)

Datura shoestring

Dendrobium mosaic

Garlic mosaic

Gloriosa stripe mosaic

Groundnut eyespot

Guinea grass mosaic (190)

Helenium virus $\mathrm{Y}$ 
Henbane mosaic (95)

Hippeastrum mosaic (117)

Iris fulva mosaic (310)

Iris mild mosaic $(116,324)$

Iris severe mosaic (338) (= bearded iris mosaic) (147)

Johnsongrass mosaic

Leek yellow stripe (240)

Lettuce mosaic (9)

Maize dwarf mosaic

Narcissus degeneration

Narcissus yellow stripe (76)

Nothoscordum mosaic

Onion yellow dwarf (158)

Ornithogalum mosaic

Papaya ringspot (= watermelon mosaic 1) $(63,84,292)$

Parsnip mosaic (91)

Passionfruit woodiness (122)

Pea seed-borne mosaic (146)

Peanut mottle (141)

Peanut stripe

(= peanut mild mottle, peanut chlorotic ring mottle)

Pepper severe mosaic

Pepper veinal mottle (104)

Plum pox (70)

Pokeweed mosaic (97)

Potato A (54)

Potato V (316)

Sorghum mosaic

Soybean mosaic (93)

Statice Y

Sugarcane mosaic (88)

Sweet potato feathery mottle

Tamarillo mosaic

$$
\text { (= sweet potato russett crack, sweet potato A) }
$$

Telfairia mosaic

Tobacco etch $(55 ; 258)$

Tobacco vein mottling (325)

Tomato (Peru) mosaic (255)

Tulip chlorotic blotch

Tulip breaking (71)

Turnip mosaic (8)

Watermelon mosaic $2(63 ; 293)$

Wisteria vein mosaic

Yam mosaic (314) (= Dioscorea green banding)

Zucchini yellow fleck

Zucchini yellow mosaic (282) 


\section{Possible members}

Aphid-borne (* aphid transmission not confirmed)

Anthoxanthum mosaic*

Aquilegia*

Aracacha Y

Asystasia gangetica mottle*

Bidens mosaic

Bryonia mottle

Canavalia maritima mosaic

Carrot mosaic

Cassia yellow blotch*

Celery yellow mosaic

Chickpea busy dwarf

Chickpea filiform

Clitoria yellow mosaic

Clover (Croatian)

Cowpea Moroccan aphid-borne

Crinum mosaic*

Cypripedium calceolus*

Daphne Y

Datura 437

Datura mosaic*

Desmodium mosaic

Dioscorea alata ring mottle

Dioscorea trifida

Dock mottling mosaic

Euphorbia ringspot

Ficus carica

Freesia mosaic

Garlic yellow streak

Guar symptomless*

Habenaria mosaic

Holcus streak*

Hungarian Datura innoxia*

Hyacinth mosaic*

Isachne mosaic*

Kennedya Y

Lily mild mottle

Maclura mosaic (239)

(particle length and coat protein MW are atypical)

Malva vein clearing

Marigold mottle

Melilotus mosaic

Mungbean mosaic*

Mungbean mottle

Narcissus late season yellows

Nerine*

$$
\text { (= jonquil mild mosaic) }
$$




\section{Palm mosaic* \\ Papaya leaf distortion \\ Passionfruit ringspot \\ Patchouli mottle \\ Peanut green mosaic \\ Peanut mosaic \\ Pecteilis mosaic \\ Pepper mild mosaic}

Pepper mottle (253) (may be synonymous with

PVY)

Perilla mottle

Plantain 7

Pleioblastus mosaic

Populus*

Primula mosaic

Reed canary mosaic

Sunflower mosaic*

Teasel mosaic

Tobacco vein banding mosaic

Tradescantia/Zebrina

Tropaeolum 1

Tropaeolum 2

Ullucus mosaic

Vallota mosaic

Vanilla mosaic

Vanilla necrosis

White Bryony mosaic

Wild potato mosaic

Zoysia mosaic

Fungal-borne

Barley yellow mosaic (143)

Oat mosaic (145)

Rice necrosis mosaic (172)

(=wheat yellow mosaic)

Wheat spindle streak mosaic (167)

Mite-borne (** mite transmission not demonstrated)

Agropyron mosaic (118)

Brome streak virus

Hordeum mosaic**

Oat necrotic mottle (169)**

Ryegrass mosaic (86)

Spartina mottle**

Wheat streak mosaic (48)

Whitefly-borne

Sweet potato mild mottle (162) 
Derivation of poty: sigla from potato $Y$

Name

\section{REFERENCES}

Buchen-Osmond, C.; Crabtree, K.; Gibbs, A.; McLean, G.; Viruses of Plants in Australia. (The Australian Nat. Univ., Canberra, 1988).

Demski, J.W.; Reddy, D.V.R.; Sowell, G.; Bays, D.: Peanut stripe virus - a new seed-borne potyvirus from China infecting groundnut (Arachis hypogaea). Ann. appl. Biol. 105:495-501 (1984).

Domier, L.L.; Shaw, J.G.; Rhoads, R.E.: Potyviral proteins share amino acid sequence homology with picorna-, como-, and caulimoviral proteins. Virology 158:20-27 (1987).

Dougherty, W.G.; Hiebert, E.: Translation of potyvirus RNA in a rabbit reticulocyte lysate: cell-free translation strategy and a genetic map of the potyviral genome. Virology 104:183-194 (1984).

Dougherty, W.G.; Allison, R.F.; Parks, T.D.; Johnston, R.E.; Feild, M.J.; Armstrong, F.B.: Nucleotide sequence at the 3 ' terminus of pepper mottle virus genomic RNA: evidence for an alternative mode of potyvirus capsid protein gene organization. Virology 146:282-291 (1985).

Edwardson, J.R.: Host range of viruses in the PVY group. Florida Agric. Exp. Station Monogr. Ser., vol. 5 (1974).

Edwardson, J.R.: Some properties of the potato virus Y group. Florida Agric. Exp. Station Monogr. Ser, vol. 4 (1974).

Francki, R.I.B.; Milne, R.G.; Hatta, T.: Potyvirus group, In Atlas of Plant Viruses, Vol. II, pp 183-218 (CRC Press, Boca Raton, Fl., 1985).

Goldbach, R.: Genome similarities between plant and animal RNA viruses. Microbiol. Sci. 4:197-202 (1987).

Hellmann, G.M.; Thornbury, D.W.; Hiebert, E.; Shaw, J.G.; Pirone, T.P.; Rhoads, R.E.: Cell-free translation of tobacco vein mottling virus RNA. II. Immunoprecipitation of products by antisera to cylindrical inclusion, nuclear inclusion, and helper component proteins. Virology 124:434-444 (1983).

Hiebert, E.; Thornbury, D.W.; Pirone, T.P.: Immunoprecipitation analysis of potyviral in vitro translation products using antisera to helper component of tobacco vein mottling virus and potato virus Y. Virology 135:1-9 (1984).

Hollings, M.; Brunt, A.A.: Potyviruses; In Kurstak, E. (ed.), Handbook of Plant Virus Infections and Comparative Diagnosis, pp. 731-807 (Elsevier/North Holland, Amsterdam, 1981).

Milne, R.G.: The Plant Viruses. The Filamentous Plant Viruses, Vol. 4. (Plenum Press, New York, 1988).

Shukla, D.D.; Inglis, A.S.; McKern, N.M.; Gough, K.H.: Coat protein of potyviruses. 2. Amino acid sequence of the coat protein of potato virus Y. Virology 152:118-125 (1986).

Shukla, D.D.; Ward, C.W.: Identification and classification of potyviruses on the basis of coat protein sequence data and serology. Arch. Virol. 106: 171-200 (1989).

Shukla, D.D.; Ward, C.W.: Structure of potyvirus coat proteins and its application in the taxonomy of the potyvirus group. Adv. Virus Res. 36: 273-314 (1989).

Vance, V.B.; Beachy, R.N.: Translation of soybean mosaic virus RNA in vitro: evidence of protein processing. Virology 132:271-281 (1984). 
Revised by M.H. Van Regenmortel

TYPE MEMBER

TOBACCO MOSAIC VIRUS

(TMV) (COMMON OR U1

STRAIN) (151)

\section{Properties of The Virus Particle}

Morphology

Elongated rigid particles about $18 \mathrm{~nm}$ diameter and $300 \mathrm{~nm}$ long, helically symmetrical with pitch $\approx 2.3 \mathrm{~nm}$.

Physicochemical properties

Nucleic acid

Protein

\section{Lipid}

Carbohydrate

Antigenic properties
$\mathrm{MW} \approx 40 \times 10^{6} ; \mathrm{S}_{20 \mathrm{w}} \approx 194 ;$ buoyant density in $\mathrm{CsCl} \approx$ $1.325 \mathrm{~g} / \mathrm{cm}^{3}$; particles very stable.

One molecule of linear positive-sense ssRNA, MW $\approx 2 \mathrm{x}$ $10^{6}$. $5^{\prime}$ terminus has the sequence $\mathrm{m}^{7} \mathrm{G}^{5} \mathrm{ppp}^{5} \mathrm{Gp}$. $3^{\prime}$ terminus has a tRNA-like structure which accepts histidine.

One coat polypeptide, $\mathrm{MW}=17-18 \times 10^{3}$.

None.

None.

Efficient immunogens.

\section{REPLICATION}

Virus replicates in the cytoplasm, inducing characteristic viroplasms; virus particles often form large crystalline arrays, visible by light microscopy. A virus-induced polymerase is detected in infected tissues; RNA replicates via an RF or RI. Coat protein is synthesized from a small monocistronic mRNA (whose base sequence is also on the viral RNA near the $3^{\prime}$ end); the mRNA is encapsidated in some members. Three other virus-specific proteins (MW $\approx 180,126$ and $30 \times 10^{3}$ ) are transcribed from full-length viral RNA. The $126 \mathrm{kDa}$ non-structural protein of TMV, thought to be a component of the viral replicase, accumulates in cytoplasmic inclusions (X-bodies), whereas the $30 \mathrm{kDa}$ non-structural transport protein is localised in plasmodesmata. 


\section{Biological ASPECTS}

Host range Most members have moderate host range.

Transmission Readily transmitted by mechanical inoculation. Some members transmitted by seed.

SEQUENCE SIMILARITIES WITH OTHER VIRUS GROUPS OR FAMILIES

Some non-structural proteins synthesized by tobacco mosaic virus share sequence similarities with nonstructural proteins of some other RNA plant viruses [e.g. tripartite viruses (alfalfa mosaic, brome mosaic and cucumber mosaic viruses), a bipartite virus (tobacco rattle virus), and a monopartite virus (carnation mottle virus)] and sindbis virus, a monopartite RNA animal virus.

\section{OTHER MEMBERS}

Cucumber green mottle mosaic (154) (= Cucumber virus 4$)$

Frangipani mosaic (196)

Kyuri green mottle mosaic

Odontoglossum ringspot (155)

Pepper mild mottle (330)

Ribgrass mosaic (152)

Sammons' Opuntia

Sunn-hemp mosaic (153)

Tobacco mild green mosaic (351)

Tomato mosaic (156)

Ullucus mild mottle

\section{Possible members}

Chara australis

Hypochoeris mosaic (273)

Derivation of tobamo: sigla from tobacco mosaic 


\section{REFERENCES}

Francki, R.I.B.; Hu, J.; Palukaitis, P.: Taxonomy of cucurbit infecting tobamoviruses as determined by serological and molecular hỳbridization analyses. Intervirology 26: 156163 (1986).

Goldbach, R.: Genome similarities between plant and animal RNA viruses. Microbiol. Sci. 4:197-202 (1987).

Hills, G.J.; Plaskitt, K.A.; Young, N.D.; Dunigan, D.D.; Watts, J.W.; Wilson, T.M.A.; Zaitlin, M.: Immunogold localization of the intra-cellular sites of structural and nonstructural tobacco mosaic virus proteins. Virology 161: 488-496 (1987).

Tomenius, K.; Clapham, D.; Meshi, T.: Localization by immunogold cytochemistry of the virus-coded $30 \mathrm{~K}$ protein in plasmodesmata of leaves infected with tobacco mosaic virus. Virology 160: 363-371 (1987).

van Regenmortel, M.H.V.; Fraenkel-Conrat, H.: The Plant Viruses, The Rod Shaped Plant Viruses, Vol. 2. (Plenum Press, New York, 1986). 


\begin{tabular}{|lll|}
\hline GROUP & COWPEA MOSAIC & COMOVIRUS \\
& VIRUS GROUP (199) & \\
\hline
\end{tabular}

Revised by R. Goldbach

\begin{tabular}{lll}
\hline TYPE MEMBER & $\begin{array}{l}\text { COWPEA MOSAIC VIRUS } \\
\text { (CPMV) (SB ISOLATE) }(47 ; 197)\end{array}$ & - \\
\hline
\end{tabular}

\section{Properties of The Virus Particle}

Morphology

All three sedimenting components, $\mathrm{T}, \mathrm{M}$ and $\mathrm{B}$ respectively, possess isometric particles $\approx 28 \mathrm{~nm}$ in diameter. The shell consists of 60 subunits of each of the two structural proteins assembled in a $\mathrm{T}=1$ icosahedral structure. There are 12 pentamers of the larger protein at the 5-fold vertices and 20 trimers of the smaller protein at the positions of 3 -fold symmetry. The two structural proteins are folded into 3 antiparallel $\beta$-barrel structures; the smaller protein forms one barrel and the large forms two barrels. The 60 copies of each protein type in the virus generate $180 \beta$-barrel domains that are arranged in a manner very similar to a $T=3$ capsid. $M$ particles contain a single molecule of RNA-2, and B particles a single molecule of RNA-1.

Physicochemical Particles are usually very stable and sediment as three properties components, $\mathrm{T}, \mathrm{M}$, and $\mathrm{B}$, respectively containing $\approx 0,25$ and $37 \%$ RNA by weight with $S_{20 w} \approx 58,98$ and 118 and $\mathrm{MWs} \approx 3.8,5.2$, and $6.2 \times 10^{6}$; buoyant densities in $\mathrm{CsCl}$ $\approx 1.29(\mathrm{~T}), 1.41(\mathrm{M})$ and $1.44-1.46(\mathrm{~B}) \mathrm{g} / \mathrm{cm}^{3}$. Partial proteolytic degradation of the smaller coat protein results in particles with increased electrophoretic mobility.

Nucleic acid

Two species of linear positive-sense ssRNA of 5889 nucleotides (RNA-1) and 3481 nucleotides (RNA-2). Complete nucleotide sequences determined. The two RNA molecules each have a high content of $\mathrm{A}+\mathrm{U}$ but have little base sequence homology. Each molecule has a poly (A) tract of variable length (RNA-1: 50-150 residues; RNA-2: $50-300$ residues) at their $3^{\prime}$ end and a $\mathrm{VPg}(\mathrm{MW} \approx 4 \mathrm{~K})$ covalently linked by a serine residue to its $5^{\prime}$ end. Enzymatic degradation of this protein does not diminish the infectivity of the RNA. Both RNA-1 and RNA-2 contain an ORF specifying a "polyprotein".

Protein

Two coat polypeptides, MWs $\approx 22$ and $42 \times 10^{3}$. The smaller, and in some members both, polypeptide(s) may 
Taxonomic status

Lipid

Carbohydrate

Antigenic properties

become partially degraded by proteolytic cleavage in vivo and in vitro.

None reported.

The coat proteins may be glycosylated. The amino acid sequence of both proteins indicates putative $\mathrm{N}$-type glycosylation sites.

Good immunogens. All members are serologically interrelated, often distantly. The coat proteins of red clover mottle virus and bean pod mottle virus show approximately $50 \%$ identity in amino acid sequence to the CPMV coat proteins.

\section{REPLICATION}

Unfractionated RNA is highly infective but neither RNA species alone can infect plants. RNA-1 can replicate in protoplasts but in the absence of RNA-2 (which carries the coat protein cistrons), no virus particles are produced. RNA-1 carries all information for viral RNA replication, including the core polymerase. Both RNA species are translated into polyproteins that are cleaved to form the functional proteins. Final translation products of RNA-1 are proteins, MWs $\approx 87 \times 10^{3}$ (viral core polymerase), $4 \times$ $10^{3}$ (VPg), $58 \times 10^{3}$ (membrane protein), $24 \times 10^{3}$ (viral proteinase), $32 \times 10^{3}$ (proteinase co-factor). The RNA-2 molecules of all comoviruses tested are translated into two overlapping polyproteins. The final products of RNA-2 translation are two overlapping proteins, $\mathrm{MW} \approx 58$ and 48 $\mathrm{x} 10^{3}$ (putative virus transport proteins), and the two coat proteins (VP37 and VP23). Membranous vesicles and electron-dense amorphous masses are the characteristic cytopathological structures found in the cytoplasm of infected cells. They contain all viral non-structural proteins, the (membrane-bound) viral polymerase activity, two dsRNA species corresponding to each of the particle RNA, and complementary RNA. Newly formed virus particles accumulate in the cytoplasm, sometimes in crystalline arrays but not in association with any cell organelle. Cell-to-cell transport probably occurs as particles, through tubular structures that penetrate through cell walls.

\section{Biological ASPECTS}

Host range

Individual members have narrow host ranges, 9 out of 13 members being restricted to a few Leguminosae species. Mosaic and mottle symptoms are characteristic. 
Transmission Natural vectors are beetles, especially Chrysomelidae. Beetles retain ability to transmit virus for days or weeks. Some are seed-transmitted. Readily transmissible experimentally by mechanical inoculation.

\section{SIMILARITIES WITH OTHER VIRUS GROUPS AND FAMILIES}

The membrane protein $\left(\mathrm{MW} \approx 58 \times 10^{3}\right)$, proteinase $(\mathrm{MW}$ $\approx 24 \times 10^{3}$ ) and core polymerase $\left(\mathrm{MW} \approx 87 \times 10^{3}\right)$ show sequence similarities to corresponding non-structural proteins of nepoviruses, potyviruses and picornaviruses. Colinearity in the genetic maps indicate genetic interrelationships between these groups. Como- and picornaviruses have, moreover, very similar capsids.

\section{OTHER MEMBERS}

Andean potato mottle (203)

Bean pod mottle (108)

Bean rugose mosaic (246)

Broad bean stain (29)

Broad bean true mosaic (20)

Cowpea severe mosaic (209)

Glycine mosaic

Pea mild mosaic

Quail pea mosaic (238)

Radish mosaic (121)

Red clover mottle (74)

Squash mosaic (43)

Ullucus C (277)

Derivation of

como: sigla from cowpea mosaic.

Name

\section{REFERENCES}

Bowyer, J.W.; Dale, J.L.; Behncken, G.M.: Glycine mosaic virus: a comovirus from Australian native glycine species. Ann. appl. Biol. 95:385-390 (1980).

Chen, Z.; Stauffacher, C.; Li, Y.; Schmidt, T.; Bomu, W.; Kamer, G.; Shanks, M.; Lomonossoff, G.P.; Johnson, J.E.: Protein-RNA interactions in an icosahedral virus at $3.0 \AA$ Åsolution. Science 245: 154-159 (1989).

Daubert, S.D.; Bruening, G.: Genome-associated proteins of comoviruses. Virology 98:246250 (1979).

Domier, L.L.; Shaw, J.G.; Rhoads, R.E.: Potyviral proteins share amino acid sequence homology with picorna-, como- and caulimoviral proteins. Virology 158:20-27 (1987). 
Eggen, R.; van Kammen, A.: RNA replication in comoviruses. In Domingo, E; Holland, J.J.; Ahlquist, P. (eds.), RNA genetics, Vol. I, pp. 49-69 (CRC Press, Boca Raton,Fl., 1988).

Francki, R.I.B.; Milne, R.G.; Hatta, T.: Comovirus group, In Atlas of plant viruses, Vol. II, pp. 1-22. (CRC Press, Boca Raton, Fl., 1985).

Franssen, H.; Leunissen, J.; Goldbach, R.; Lomonossoff, G.; Zimmern, D.: Homologous sequences in non-structural proteins from cowpea mosaic virus and picornaviruses. EMBO Journal 3: 855-861 (1984).

Fulton, J.P.; Scott, H.A.: A serogrouping concept for legume comoviruses. Phytopathology 69:305-306 (1979).

Goldbach, R.: Genome similarities between plant and animal RNA viruses. Microbiol. Sci. 4:197-202 (1987).

Goldbach, R.; Rezelman, G.; van Kammen, A.: Independent replication and expression of Bcomponent RNA of cowpea mosaic virus. Nature 286:297-300 (1980).

Goldbach, R.; van Kammen, A.: Structure, replication, and expression of the bipartite genome of cowpea mosaic virus. In Davies, J.W. (ed.), Molecular Plant Virology, Vol. II, pp. 83-120. (CRC Press, Boca Raton, Fl., 1985).

Goldbach, R.; Wellink, J.: Evolution of plus-strand RNA viruses. Intervirology 29: 260-267 (1988).

Rezelman, G.; Goldbach, R.; van Kammen, A.: Expression of bottom component RNA of cowpea mosaic virus in cowpea protoplasts. J. Virol. 36: 366-373 (1980).

Shanks, M.; Stanley, J.; Lomonossoff, G.P.: The primary structure of red clover mottle virus middle component RNA. Virology 155: 697-706 (1986).

van Lent, J.M.W.; Wellink, J.; Goldbach, R.: Evidence for the involvement of the 58K and $48 \mathrm{~K}$ proteins in the intercellular movement of cowpea mosaic virus. J. gen. Virol. 71 : 219-223 (1990).

Wellink, J.; van Lent, J.M.W.; Goldbach, R.: Detection of viral proteins in cytopathic structures in cowpea protoplasts infected with cowpea mosaic virus. J. gen. Virol. 69: 751-755 (1988). 


\begin{tabular}{|ll|}
\hline GROUP & $\begin{array}{l}\text { CARNATION RINGSPOT } \\
\text { VIRUS GROUP }\end{array}$ \\
\hline
\end{tabular}

Revised by R.I. Hamilton

\begin{tabular}{lll}
\hline TYPE MEMBER & $\begin{array}{l}\text { CARNATION RINGSPOT } \\
\text { VIRUS (CRSV) (21) }\end{array}$ & - \\
\hline
\end{tabular}

\section{Properties of The Virus Particle}

Morphology Polyhedral particles 31-34 $\mathrm{nm}$ in diameter. The arrangement of the two RNA species within particles has not been established.

Physicochemical properties

Nucleic acid

Protein

Lipid

Carbohydrate

Antigenic properties
$\mathrm{MW} \approx 7.1 \times 10^{6} ; \mathrm{S}_{20 \mathrm{w}} \approx 133$; buoyant density in $\mathrm{CsCl} \approx$ $1.37 \mathrm{~g} / \mathrm{cm}^{3}$; alkaline $\mathrm{pH}(7-8)$ induces swelling of virus particles.

Two molecules of positive-sense ssRNA, MW $\approx 1.5$ and $0.5 \times 10^{6}$. The larger RNA contains the coat protein cistron. RNA-1 (3889 nt) and RNA-2 (1448 nt) of red clover necrotic mosaic virus have been sequenced. Both have a $5^{1} \mathrm{~m}^{7} \mathrm{GpppA}$; neither is polyadenylated or contains a VpG. RNA-1 contains three ORFs for proteins, $M W \approx$ 27,37 (capsid) and $57 \times 10^{3}$; RNA-2 contains a single ORF for protein of $\mathrm{MW}=35 \times 10^{3}$.

One coat polypeptide, $\mathrm{MW} \approx 40 \times 10^{3}$.

None reported.

None reported.

Efficient immunogens. Single precipitin line in gel diffusion tests.

\section{REPLICATION}

Particles located in the cytoplasm, scattered and clustered; patches of densely stained, amorphous material also seen in cytoplasm of some cells. RNA-1 of red clover necrotic mosaic virus can replicate alone in cowpea and tobacco protoplasts. Two dsRNAs corresponding to the genomic ssRNAs and a third corresponding to a subgenomic RNA derived from RNA-1 have been detected in infected plants. Evidence suggests that coat protein may be translated from subgenomic RNA derived from RNA-1. Three proteins of 
MW $\approx 39$ (capsid protein) 36 and $34 \times 10^{3}$ are translated in vitro.

\section{Biological ASPECTS}

Host range

Transmission
Each virus has a wide host range.

Transmitted through soil. Readily transmissible experimentally by mechanical inoculation.

\section{OTHER MEMBERS}

Red clover necrotic mosaic (181)

Sweet clover necrotic mosaic (321)

\section{Derivation of diantho: from Dianthus, the generic name of carnation.}

\section{Name}

\section{REFERENCES}

Dodds, J.A.; Tremaine, J.H.; Ronald, W.P.: Some properties of carnation ringspot virus single- and double-stranded ribonucleic acid. Virology 83:322-328 (1977).

Hiruki, C.; Rao, D.V.; Chen, M.H.; Okuno, T.; Figueiredo, G.: Characterization of sweet clover necrotic mosaic virus. Phytopathology 74:482-486 (1984).

Hiruki, C.: The dianthoviruses: a distinct group of isometric plant viruses with bipartite genome. Adv. Virus Res. 33:257-300 (1987).

Lommel, S.A.; Weston-Fina, M.; Xiong, Z.; Lomonossoff, G.P.: The nucleotide sequence and gene organisation of red clover necrotic mosaic virus RNA-2. Nuc. Acids Res. 16: 8587-8602 (1988).

Morris-Krsinich, B.A.M.; Forster, R.L.S.; Mossop, D.W.: Translation of red clover necrotic mosaic virus RNA in rabbit reticulocyte lysate: identification of the virus coat protein cistron on the larger RNA strand of the bipartite genome. Virology 124:349-356 (1983).

Okuno, T.; Hiruki, C.; Rao, D.V.; Figueiredo, G.C.: Genetic determinants distributed in two genomic RNAs of sweet clover necrotic mosaic, red clover necrotic mosaic and clover primary leaf necrosis viruses. J. gen. Virol. 64:1907-1914 (1983).

Osman, T.A.M.; Buck, K.W.: Replication of red clover necrotic mosaic virus RNA in cowpea protoplasts: RNA-1 replicates independently of RNA 2. J. gen. Virol. 68: 289-296 (1987).

Osman, T.A.M.; Buck, K.W.: Double-stranded RNAs isolated from plant tissue infected with red clover necrotic mosaic virus correspond to genomic and subgenomic single-stranded RNAs. J. gen. Virol. 71: 945-948 (1990).

Xiong, Z.; Lommel, S.A.: The complete nucleotide sequence and genome organization of red clover necrotic mosaic virus RNA-1. Virology 171: 543-554 (1989). 
Revised by R. Milne

\begin{tabular}{l} 
TYPE MEMBER \\
\hline Morphology \\
Physicochemical \\
properties
\end{tabular}

BROAD BEAN WILT VIRUS (BBWV),SEROTYPE I (81)

\section{Properties of The Virus Particle}

All three sedimenting components consist of isometric particles $\approx 30 \mathrm{~nm}$ in diameter with hexagonal outlines. $\mathrm{M}$ particles contain a single molecule of RNA-2, B particles a single molecule of RNA-1.

Physicoch
properties

Nucleic acid

Protein

Lipid

Carbohydrate

Antigenic properties

Host range

Transmission
Particles very stable, sedimenting as three components, $\mathrm{T}$, $\mathrm{M}$ and $\mathrm{B}$, respectively containing $\approx 0,25$ and $35 \%$ RNA by weight with $S_{20 w}$ of 56-63, 93-100 and 113-126.

Two species of linear positive-sense ssRNA with $\mathrm{MW} \approx$ $2.1 \times 10^{6}$ (RNA-1) and $1.5 \times 10^{6}$ (RNA-2).

Two coat polypeptides of MW $\approx 43 \times 10^{3}$ and $27 \times 10^{3}$.

None reported.

None reported.

Efficient immunogens. Distant serological relationships between members.

\section{REPLICATION}

Both RNA species are necessary for infectivity. Inclusion bodies consisting of large masses of convoluted membranes and vesicles occur in the cytoplasm. Virus particles occur scattered in the cytoplasm, or in single files within cytoplasmic tubules and in the plasmodesmata. The virus particles also tend to aggregate to form crystals or striking tubular or rectangular arrays.

\section{Biological ASPECTS}

Wide. Symptoms range from ringspots, mottles, mosaic, distortion, wilting and apical necrosis to symptomless infection.

Transmitted by several species of aphid in the nonpersistent manner. Readily transmissible experimentally 
by mechanical inoculation. Not known to be seedtransmitted.

\section{OTHER MEMBERS}

Broad bean wilt virus, serotype II

Lamium mild mosaic virus

Derivation of faba: L. Faba, bean; also Vicia faba, broad bean.

Name

\section{REFERENCES}

Doel, T.R.: Comparative properties of type, nasturtium ringspot and petunia ringspot strains of broad bean wilt virus. J. gen. Virol. 26:95-108 (1975).

Francki, R.I.B.; Milne, R.G.; Hatta, T.: Comovirus group, In Atlas of Plant Viruses, Vol. II, pp. 1-22 (CRC Press, Boca Raton, Fl., 1985).

Lisa, V.; Luisoni, E.; Boccardo, G.; Milne, R.G.; Lovisolo, O.: Lamium mild mosaic virus: a virus distantly related to broad bean wilt. Ann. appl. Biol. 100:467-476 (1982).

Uyemoto, J.K.; Provvidenti, R.: Isolation and identification of two serotypes of broad bean wilt virus. Phytopathology 64:1547-1548 (1974). 


\begin{tabular}{|lll|}
\hline GROUP & $\begin{array}{l}\text { TOBACCO RINGSPOT } \\
\text { VIRUS GROUP (185) }\end{array}$ & NEPOVIRUS \\
\hline
\end{tabular}

Revised by G.P. Martelli

\begin{tabular}{lll}
\hline TYPE MEMBER & $\begin{array}{l}\text { TOBACCO RINGSPOT VIRUS } \\
\text { (TOBRV) }(17 ; 309)\end{array}$ & - \\
\hline
\end{tabular}

\section{Properties of the Virus Particle}

Morphology

All three sedimenting components possess isometric particles $\approx 28 \mathrm{~nm}$ in diameter, often with hexagonal outlines. M particles contain a single molecule of RNA-2, B particles a single molecule of RNA-1; some members have a second type of $\mathrm{B}$ particle containing two molecules of RNA-2.

Physicochemical properties

Particles of most members are stable and sediment as three components, $\mathrm{T}, \mathrm{M}$ and $\mathrm{B}$, respectively containing $\approx 0,27$ 40 and $42-46 \%$ RNA by weight, with $S_{20 w}=49-56,86-$ 128 and 115-134, and MWs $\left(x 0^{6}\right)=3.2-3.4,4.6-5.8$, and 6.0-6.2; buoyant densities in $\mathrm{CsCl} \approx 1.28(\mathrm{~T}), 1.43$ $1.48(\mathrm{M})$, and $1.51-1.53(\mathrm{~B}) \mathrm{g} / \mathrm{cm}^{3}$. Satellite RNAs become packaged in helper virus capsids to form additional sedimenting and buoyant density components.

Nucleic acid

Two species of linear positive-sense ssRNA with MW = 2.4-2.8 x $10^{6}$ (RNA-1) (7365 nt and $7212 \mathrm{nt}$ in tomato black ring and grapevine chrome mosaic, respectively) and 1.3-2.4 x $10^{6}$ (RNA-2) (4662 and $4441 \mathrm{nt}$ in tomato black ring and grapevine chrome mosaic, respectively). The two RNA molecules have little base sequence homology. Each RNA molecule has a poly (A) tract at its $3^{\prime}$ end and a Vpg $\left(\mathrm{MW}=3-6 \times 10^{3}\right.$ ) covalently linked to its $5^{\prime}$ end; enzymatic degradation of this polypeptide (genome-linked protein) decreases or abolishes the infectivity of the RNA. 'Satellite' RNA molecules of two sizes and types are associated with some members. 'Large' satellite RNAs are linear messenger molecules of MW 0.37-0.47 x $10^{6}$ (1114$1375 \mathrm{nt}$ ) encoding a polypeptide of $\mathrm{MW}=38-48 \times 10^{3}$. 'Small' satellite RNAs are non-messenger molecules of MW 0.10-0.16 x 106 (300-457 nt) which have a strong modulating effect on symptom expression. In vitro transcripts of cDNA clones of TobRV and tomato black ring satellite RNAs are biologically active. 
Taxonomic status

Protein

\section{Lipid}

Carbohydrate

Antigenic properties

Host range

Transmission
English vernacular name

International name

One coat polypeptide, $\mathrm{MW}=55-60 \times 10^{3}$; probably 60 copies per species of particle. Most of the possible members are so listed because they have two or three polypeptides of lower MW.

None reported.

None reported.

Efficient immunogens. Few instances of serological cross-reactivity between members.

\section{REPLICATION}

Unfractionated RNA induces many local lesions in assay hosts, but separated RNA species induce few or none. RNA-1 can replicate in protoplasts but, in the absence of RNA-2 (which carries the coat protein cistron), no virus particles are produced. RNA-1 carries information for the polymerase function and for the Vpg. Virus-induced RNA-dependent RNA polymerase is present in TobRVinfected tissue along with short dsRNA molecules of unknown function. Inhibitor studies indicate that nepovirus proteins are synthesized on cytoplasmic ribosomes. Both RNA species are translated in vitro into large polypeptides approaching in size of their theoretical coding capacity; these 'polyproteins' must be cleaved in vivo to form the functional proteins. The RNA-2 polyprotein has the coat polypeptide at its C-terminal end. 'Homology' comparisons suggest a 'transport protein' gene in RNA-2 and polymerase and protease domains in the RNA-1 polyprotein. Characteristic vesiculated inclusion bodies occur in the cytoplasm, usually adjacent to the nucleus. Virus particle antigen accumulates in these structures, which may be the sites of synthesis or assembly of virus components. Newly formed virus particles accumulate in the cytoplasm. They are also commonly found in the plasmodesmata and in single files within tubules in the cytoplasm.

\section{Biological ASPECTS}

Wide. Ringspot symptoms are characteristic, but spotting or mottling symptoms are probably more frequent. Leaves produced later are often symptomless though infected ('recovery'). Symptomless infection is common.

Seed transmission (via either gamete) is very common. There is circumstantial evidence for transmission of one member to plants pollinated with pollen from infected 
plants. Most members are transmitted by soil-inhibiting longidorid nematodes, but one is reported also to be transmitted aerially and the vectors of others are unknown. Nematodes retain ability to transmit virus for weeks or months but cease to transmit after moulting. The viruses do not multiply in the vector. Readily transmissible experimentally by mechanical inoculation.

\section{SIMILARITIES WITH OTHER VIRUS GROUPS OR FAMILIES}

Tomato black ring virus shares significant similarities with como-, poty- and picorna viruses, e.g. genome organization, VPg at 5'-end and poly A at 3 '-end of the genomes, post-translational processing of polyproteins and sequence similarities among non-structural proteins.

\section{OTHER MEMBERS}

Arabis mosaic (16)

Arracacha A (216)

Artichoke Italian latent (176)

Artichoke yellow ringspot (271)

Blueberry leaf mottle (267)

Cassava American latent

Cassava green mottle

Cherry leaf roll $(80 ; 306)$

Chicory yellow mottle (132)

Cocoa necrosis (173)

Crimson clover latent

Cycas necrotic stunt

Grapevine Bulgarian latent (186)

Grapevine chrome mosaic (103)

Grapevine fanleaf (28)

Grapevine Tunisian ringspot

Hibiscus latent ringspot (233)

Lucerne Australian latent (225)

Mulberry ringspot (142)

Myrobalan latent ringspot (160)

Olive latent ringspot (301)

Peach rosette mosaic (150)

Potato black ringspot (206)

Potato U

Raspberry ringspot $(6 ; 198)$

Tomato black ring (38)

Tomato ringspot $(18 ; 290)$

\section{Possible members}

Arracacha B (270)

Artichoke vein banding (285) 
Cherry rasp leaf (159)

Lucerne Australian symptomless

Rubus Chinese seed-borne

Satsuma dwarf (208)

Strawberry latent ringspot (126)

Tomato top necrosis

Derivation of Name nepo: sigla from nematode, polyhedral to distinguish these viruses from the tobravirus group.

\section{REFERENCES}

Brault, V.; Hibrand, L.; Candresse, T.; Le Gall, O.; Dunez, J.: Nucleotide sequence and genetic organization of Hungarian grapevine chrome mosaic nepovirus RNA 2. Nuc. Acids Res. 17: 7809-7819 (1989).

Fritsch, C.; Mayo, M.A.; Murant, A.F.: Translation products of genome and satellite RNAs of tomato black ring virus. J. gen. Virol. 46:381-389 (1980).

Gerlach, W.L.; Buzayan, J.M.; Schneider, I.R.; Bruening, G.: Satellite tobacco ringspot virus RNA: biological activity of DNA clones and their in vitro transcripts. Virology 151: 172-185 (1986).

Goldbach, R.: Genome similarities between plant and animal RNA viruses. Microbiol. Sci. 4:197-202 (1987).

Greif, C.; Hemmer, O.; Demangeat, G.; Fritsch, C.: In vitro synthesis of biologically active transcripts of tomato black ring virus satellite RNA. J. gen. Virol. 71: 907-915 (1990).

Greif, C.; Hemmer, O.; Fritsch, C.: Nucleotide sequence of tomato black ring virus RNA-1. J. gen. Virol. 69: 1517-1529 (1988).

Le Gall, O.; Candresse, T.; Brault, V.; Dunez, J.: Nucleotide sequence of Hungarian grapevine chrome mosaic nepovirus RNA 1. Nuc. Acids Res. 17: 7795-7807 (1989).

Martelli, G.P.; Taylor, C.E.: Distribution of viruses and their nematode vectors; In Harris, K.F. (ed.), Advances in Disease Vector Research, Vol. 6, pp. 151-189. (Springer, Wien, New York, 1989).

Mayo, M.A.; Barker, H.; Harrison, B.D.: Polyadenylate in the RNA of five nepoviruses. J. gen. Virol. 43:603-610 (1979).

Mayo, M.A.; Barker, H.; Harrison, B.D.: Specificity and properties of the genome-linked proteins of nepoviruses. J. gen. Virol. 59:149-162 (1982).

Meyer, M.; Hemmer, O.; Mayo, M.A.; Fritsch, C.: The nucleotide sequence of tomato black ring virus RNA-2. J. gen. Virol. 67:1257-1271 (1986).

Mircetich, S.M.; Sanborn, R.R.; Ramos, D.E.: Natural spread, graft-transmission, and possible etiology of walnut blackline disease. Phytopathology 70:962-968 (1980).

Murant, A.F.: Nepoviruses; In Kurstak, E. (ed.), Handbook of Plant Virus Infections and Comparative Diagnosis, pp. 197-238. (Elsevier/North Holland, Amsterdam, 1981).

Robinson, D.J.; Barker, H.; Harrison, B.D.; Mayo, M.A.: Replication of RNA-1 of tomato black ring virus independently of RNA-2. J. gen. Virol. 51:317-326 (1980).

Rubino, L.; Tousignant, M.E.; Steger, G.; Kaper, J.M.: Nucleotide sequence and structural analysis of two satellite RNAs associated with chicory yellow mottle virus. J. gen. Virol. 71: 1897-1903 (1990).

Stace-Smith, R.; Ramsdell, D.C.: Nepoviruses of-the Americas; In Harris, K.F. (ed.), Current Topics in Vector Research, Vol. 5, pp. 131-166: (Springer, Wien, New York, 1987).

Walter, B.; Ladeveze, I.; Etienne, L.; Fuchs, M.: Some properties of a previously undescribed virus from cassava: Cassava American latent virus. Ann. appl. Biol. 115: 279-289 (1989). 


FAMILY NODAMURA VIRUS GROUP NODAVIRIDAE

Revised by R.R. Rueckert

\begin{tabular}{lcc}
\hline \hline GENUS & - & NODAVIRUS \\
\hline TYPE SPECIES & NODAMURA VIRUS & - \\
\hline
\end{tabular}

\section{Properties of the Virus Particle}

Morphology

Virus particles are unenveloped, roughly spherical, 29-30 $\mathrm{nm}$ in diameter. Icosahedral shell symmetry $(\mathrm{T}=3)$. Structure of the protein shell of BBV has been solved to atomic dimensions.

Physicochemical properties

Nucleic acid

Protein

Lipid

Carbohydrate

Antigenic properties
MW $8 \times 10^{6} ; \mathrm{S}_{20 \mathrm{w}}=135-142$; buoyant density in $\mathrm{CsCl}=$ $1.30-1.35 \mathrm{~g} / \mathrm{cm}^{3}$ (varies with species). Stable in $1 \%$ sodium dodecyl sulfate except Boolara virus; black beetle and flock house viruses are stable at $\mathrm{pH} 3$ and form stable crystals; resistant to organic solvents.

Two ssRNA molecules, one each of 1.1 and $0.48 \times 10^{6}$ in the same particle, $16 \%$ RNA by weight; both molecules of the isolated RNA are required for infection.

One major polypeptide species ( $\beta$ ) of MW $39 \times 10^{3}$ and one minor species $(\gamma)$ of $\mathrm{MW}=4.5 \times 10^{3}$; derived by proteolytic cleavage of a precursor protein $(\alpha)$ of MW= 44 $\mathrm{x} 10^{3}$. Mature virions often contain some uncleaved precursor protein.

Probably none.

Not determined.

All are cross-reactive by double-diffusion precipitin line test but members are distinguishable by other properties such as neutralization, electric charge and host range.

\section{REPLICATION}

The virus replicates in the cytoplasm. RNA synthesis is resistant to actinomycin $\mathrm{D}$. Infected cells contain three ssRNAs: RNA $1\left(\mathrm{MW}=1.1 \times 10^{6}\right)$, RNA $2(\mathrm{MW}=0.48$ $\left.\mathrm{x} 10^{6}\right)$ and RNA $3\left(\mathrm{MW}=0.15 \times 10^{6}\right)$. RNA 3 is not packaged into virions. RNA 1 codes for protein $\mathrm{A}$ (MW = $105 \times 10^{3}$ ); the latter is probably a component of the viral RNA polymerase. RNA 2 codes for coat protein (MW = $\left.44 \times 10^{3}\right)$; and RNA 3, for protein B $\left(\mathrm{MW}=10 \times 10^{3}\right)$ of 
unknown function. Cells infected with isolated RNA 1 synthesize RNA 1 and RNA 3 but no RNA 2. Both RNA 1 and RNA 2 are required for production of virions. RNA 2 strongly inhibits synthesis of RNA 3 . Messenger activity of the RNAs in infected cells is RNA $3>$ RNA $2>$ RNA 1. Cultured virus forms defective-interfering particles readily if not passaged at low multiplicity of infection. Readily generates persistently infected cells, resistant to infection by wild type virus.

\section{Biological Aspects}

Host range Natural - All species were isolated from insects, Diptera, Coleoptera or Lepidoptera. Viruses are not notably hostspecific. Experimental - Most, if not all, can be propagated in the common wax moth, Galleria mellonella. Nodamura virus, unlike other members, grows in suckling mice but not in cultured Drosophila cells. All except Nodamura virus form plaques on Drosphila cell monolayers.

Transmission Nodamura virus is transmissible to suckling mice by Aedes aegypti.

\section{OTHER MEMBERS}

Black beetle virus

Flock house virus

Gypsy moth virus

Boolarra virus

Manawatu virus

\section{Derivation of} Name

Nodamura: village in Japan where type species was isolated.

\section{REFERENCES}

Dasgupta, R.; Sgro, J.-Y.: Nucleotide sequences of three Nodavirus RNA2's: the messengers for their coat protein precursors. Nuc. Acids Res. 17: 7525-7526 (1989).

Dasmahapatra, B.; Dasgupta, R.; Ghosh, A.; Kaesberg, P.: Structure of the Black Beetle Virus genome and its functional implications. J. Mol. Biol. 182:183-189 (1985).

Dasmahapatra, B.; Dasgupta, R.; Saunders, K.; Selling, B.H.; Gallagher, T.M.; Kaesberg, P.: Infectious RNA derived by transcription from cloned cDNA copies of the genomic RNA of an insect virus. Proc. Natl. Acad. Sci. USA 83: 63-66 (1986).

Friesen, P.D.; Rueckert, R.R.: Synthesis of Black Beetle Virus proteins in cultured Drosophila cells: Differential expression of RNAs 1 and 2. J. Virol. 37: 876-886 (1981).

Gallagher, T.M.; Friesen, P.D.; Rueckert, R.R.: Autonomous replication and expression of RNA 1 from Black Beetle Virus. J. Virol. 46:481-489 (1983). 
Gallagher, T.M.; Rueckert, R.R.: Assembly-dependent maturation cleavage in provirions of a small icosahedral insect ribovirus. J. Virol. 62: 3399-3406 (1988).

Greenwood, L.K.; Moore, N.F.: Purification and partial characterization of a small RNA-virus from Lymantria - Identification of a Nodamura-like virus. Microbiologica 5:49-52 (1982).

Guarino, L.A.; Ghosh, A.; Dasmahapatra, B.; Dasgupta, R.; Kaesberg, P.: Sequence of the Black Beetle Virus subgenomic RNA and its location in the viral genome. Virology 139: 199-203 (1984).

Hosur, M.V.; Schmidt, T.; Tucker, R.C.; Johnson, J.E.; Gallagher, T.M.; Selling, B.H.; Rueckert, R.R.: Structure of an insect virus at $3.0 \AA$ resolution. Proteins: structure, function, and genetics 2: 167-176 (1987).

Hosur, M.V.; Schmidt, T.; Tucker, R.C.; Johnson, J.E.; Selling, B.H.; Rueckert, R.R.: Black Beetle Virus - Crystallization and particle symmetry. Virology 133:119-127 (1984).

Kaesberg, P.; Dasgupta, R.; Sgro, J.-Y.; Wery, J.-P.; Selling, B.H.; Hosur, M.V.; Johnson, J.E.: Structural homology among four nodaviruses as deduced by sequencing and $\mathrm{x}$-ray crystallography. J. Mol. Biol. 214: 423-435 (1990).

Moore, N.F.; Tinsley, T.W.: The small RNA viruses of insects. Arch. Virol. 72:229-245 (1982).

Reavy, B.; Moore, N.F.: The replication of small RNA-containing viruses of insects. Microbiologica 5:63-84 (1982).

Reinganum, C.; Bashiruddin, J.B.; Cross, G.F.: Boolarra virus: a member of the Nodaviridae isolated from Oncopera intricoides (Lepidoptera: Hepialidae). Intervirology 24: 10-17 (1985).

Scotti, P.D.; Dearing, S.; Mossop, D.W.: Flock House Virus: A Nodavirus isolated from Costelytra zealandica (White) (Coleoptera: Scarabaediae). Arch. Virol. 75:181-189 (1983).

Selling, B.H.; Allison, R.F.; Kaesberg, P.: Genomic RNA of an insect virus directs synthesis of infectious virions in plants. Proc. Natl. Acad. Sci. USA 87: 434-438 (1990).

Selling, B.H.; Rueckert, R.R.: Plaque assay for Black Beetle Virus. J. Virology 51: 251-253 (1984).

Wery, J.-P.; Johnson, J.E.: Molecular biology at atomic resolution: the structure of an insect virus and its functional implications. Analyt. Chem. 61: 1341A-1350A (1989). 
Revised by R. Hull \& S. Salquero

\begin{tabular}{lll}
\hline TYPE MEMBER & PEA ENATION MOSAIC & - \\
& VIRUS (PEMV) $(25 ; 257)$ & \\
\hline
\end{tabular}

\section{Properties of The Virus Particle}

Morphology Polyhedral particles, $\approx 28 \mathrm{~nm}$ in diameter.

Physicochemical Particles of two types (B and T) with MWs $\approx 5.7 \times 10^{6}$ properties (B) and $\approx 4.6 \times 10^{6}(\mathrm{~T}) ; S_{20 \mathrm{w}} \approx 112(\mathrm{~B})$ and $\approx 99(\mathrm{~T})$; buoyant density in $\mathrm{CsCl} \approx 1.42 \mathrm{~g} / \mathrm{cm}^{3}$ for $\mathrm{B}$ component; $\mathrm{T}$ component is disrupted; in $\mathrm{Cs}_{2} \mathrm{SO}_{4} \approx 1.38 \mathrm{~g} / \mathrm{cm}^{3}$ for both components. Particles readily disrupted in neutral chloride salts.

Nucleic acid Two molecules of linear positive-sense ssRNA, MWs $\approx$ 1.7 and $1.3 \times 10^{6}$. Some strains also contain a third RNA component with $\mathrm{MW} \approx 0.3 \times 10^{6}$ which is considered to be a satellite.

Protein

Major coat polypeptide, $\mathrm{MW} \approx 22 \times 10^{3}$, minor polypeptide $\left(\mathrm{MW} \approx 28 \times 10^{3}\right)$ associated with aphid transmissibility.

\section{Lipid None reported.}

Carbohydrate None reported.

Antigenic properties

Weakly to moderately immunogenic. One or two precipitin lines are formed in gel diffusion tests.

\section{REPLICATION}

Virus particles found in the nucleus. Vesicular cytopathological structures originating from nuclear membranes develop in infected cells. In vitro translation of RNA-1 yields two major proteins, $\mathrm{vp} 2$ (MW $\approx 88 \mathrm{x}$ $10^{3}$ ) and vp4 $\left(\mathrm{MW} \approx 30 \times 10^{3}\right)$; a minor protein, vp1 (MW $\approx 147 \times 10^{3}$ ) is also obtained. RNA-2 is translated into vp3 $\left(\mathrm{MW} \approx 45 \times 10^{3}\right)$. PEMV antiserum precipitated vp2, suggesting that this protein contains sequences related to those of the coat protein. A VPg-like protein (MW $\approx 17.5$ $x 10^{3}$ ) is linked to the 5 -ends of both genomic RNAs; neither are polyadenylated. 


\section{Biological ASPECTS}

Host range Infects many legumes but few species in other families.

Transmission Transmitted by aphids in a persistent manner. Readily transmissible experimentally by mechanical inoculation, often with loss of aphid transmissibility.

\section{REFERENCES}

Demler, S.A.; de Zoeten, G.A.: Characterization of a satellite RNA associated with pea enation mosaic virus. J. gen. Virol. 70: 1075-1084 (1989).

de Zoeten, G.A.; Gaard, G.; Diez, F.B.: Nuclear vesiculation associated with pea enation mosaic virus-infected plant tissue. Virology 48:638-647 (1972).

Gabriel, C.J.; de Zoeten, G.A.: The in vitro translation of pea enation mosaic virus RNA. Virology 139:223-230 (1984).

Hull, R.: Particle differences related to aphid-transmissibility of a plant virus. J. gen. Virol. 34:183-187 (1977).

Hull, R.: Pea enation mosaic virus; In Kurstak, E. (ed.), Handbook of Plant Virus Infections and Comparative Diagnosis, pp. 239-256. (Elsevier/North Holland, Amsterdam, 1981).

Powell, C.A.; de Zoeten, G.A.: Replication of pea enation mosaic virus RNA in isolated pea nuclei. Proc. Natl. Acad. Sci. USA 74: 2919-2922 (1977).

Powell, C.A.; de Zoeten, G.A.; Gaard, G.: The localization of pea enation mosaic virusinduced RNA-dependent RNA polymerase in infected peas. Virology 78:135-143 (1977).

Reisman, D.; de Zoeten, G.A.: A covalently linked protein at the 5'-ends of the genomic RNAs of pea enation mosaic virus. J. gen. Virol. 62:187-190 (1982). 


\section{GROUP \\ SOIL-BORNE WHEAT MOSAIC FUROVIRUS} VIRUS GROUP

Compiled by A.A. Brunt

\begin{tabular}{lll}
\hline TYPE MEMBER & $\begin{array}{l}\text { SOIL-BORNE WHEAT MOSAIC } \\
\text { VIRUS (SBWMV) (77) }\end{array}$ & - \\
\hline
\end{tabular}

Morphology

\section{Properties of The Virus Particle}

Physicochemical properties

Nucleic acid

Protein

Lipid

Carbohydrate

Antigenic properties
Fragile rod-shaped particles $\approx 20 \mathrm{~nm}$ in diamter with predominant lengths of $92-160 \mathrm{~nm}$ and $250-300 \mathrm{~nm}$; two possible members also have particles $380-390 \mathrm{~nm}$ long. Particle helically symmetrical; the protein helix of beet necrotic yellow vein virus particles is right-handed with a pitch of $2.6 \mathrm{~nm}$ and $121 / 4$ subunits per turn.

Two or more sedimenting components, number depending on member. $S_{20 \mathrm{w}}=220-230$ (long particles), 170-225 (shorter particles), and 126-177 (deletion mutants); buoyant density in $\mathrm{CsCl} \approx 1.32 \mathrm{~g} / \mathrm{cm}^{3}$.

Two molecules of linear ssRNA, RNA-1 $=5.9-6.9 \mathrm{~kb}$ $\left(\mathrm{MW}=1.83-2.42 \times 10^{6}\right), \mathrm{RNA}-2=3.5-4.3 \mathrm{~kb}(\mathrm{MW}=$ $\left.1.23-1.83 \times 10^{6}\right)$ and deleted molecules $=2.1-2.4 \mathrm{~kb}(\mathrm{MW}$ $\left.=0.74-0.84 \times 10^{6}\right)$. The two RNAs are not polyadenylated at 3'-end and do not have a 5'-cap structure of Vpg.

Beet necrotic yellow vein virus is unusual in having four ssRNAs $(6.75,4.61,1.77$ and $1.47 \mathrm{~kb}$, excluding poly $\mathrm{A}$ tails): all four have been sequenced and shown to be 3'polyadenylated (65-140 residues) and to have 5'-terminal caps ( $\left.\mathrm{m}^{7} \mathrm{GpppA}\right)$; RNAs 3 and 4 also have unusually long (445 and 379 nucleotides, respectively) 5 '-non-coding regions.

Single polypeptide MW $=19.7-23.0 \times 10^{3}$ (but mostly $\approx$ $\left.20 \times 10^{3}\right)$.

None reported.

None reported.

Most members are fairly good immunogens. Type member is serologically fairly distantly related to potato mop top, broadbean necrosis, oak golden stripe and sorghum chlorotic spot viruses. 


\section{REPLICATION}

The virus particles occur in cytoplasm and vacuoles of parenchyma cells; they are sometimes scattered throughout the cytoplasm but, especially in older cells, occur more frequently in aggregates. Some members also induce in the cytoplasm, inclusions consisting of interwoven masses of tubules, ribosomes and virus particles.

RNA-1 directs the synthesis of a large polypeptide (MW = $180-220 \times 10^{3}$ ) which accounts for $80-90 \%$ of its coding capacity. RNA-2 encodes for coat protein. The coat protein cistron, can undergo efficient translational readthrough to produce two larger polypeptides in vitro $\left(\mathrm{MW}=25-28 \times 10^{3}\right.$ and either $90-100 \times 10^{3}$ or, for the deletion mutants, 55-66 $\times 10^{3}$ ). Potato mop top virus infected plants contain three dsRNAs $(6.5,3.2$ and 2.4 $\mathrm{kbp}$ ) corresponding to the three viral ssRNAs of $6.5,3.2$ and $2.5 \mathrm{~kb}$.

\section{Biological ASPECTS}

Host range

Transmission
Natural host ranges very narrow, but experimental host ranges of some members moderately wide.

Natural transmission by plasmodiophorid fungi (Polymyxa graminis, $P$. betae or Spongospora subterranea); one member is seedborne. Transmitted experimentally by mechanical inoculation.

\section{OTHER MEMBERS}

Oat golden stripe

Peanut clump (235)

Potato mop-top (138)

Sorghum chlorotic spot

\section{Possible members}

Beet necrotic yellow vein (144)

Beet soil-borne

Broadbean necrosis (223)

Hypochoeris mosaic (273)

Nicotiana velutina mosaic (189)

Rice stripe necrosis 


\section{REFERENCES}

Adams, M.J.; Jones, P.; Swaby, A.G.: Purification and some properties of oat golden stripe virus. Ann. appl. Biol. 112: 285-290 (1988).

Bouzoubaa, S.; Guilley, H.; Jonard, G.; Richards, K.; Putz, C: Nucleotide sequence analysis of RNA-3 and RNA-4 of beet necrotic yellow vein virus isolates F2 and G1. J. gen. Virol. 66: 1553-1564 (1985).

Bouzoubaa, S.; Ziegler, V.; Beck, D.; Guilley, H.; Richards, K.; Jonard, G.: Nucleotide sequence of beet necrotic yellow vein virus RNA-2. J. gen. Virol. 67: 1689-1700 (1986).

Bouzoubaa, S.; Quillet, L.; Guilley, H.; Jonard, G.; Richards, K.: Nucleotide sequence of beet necrotic yellow vein virus RNA-1. J. gen. Virol. 68: 615-626 (1987).

Brunt, A.A.; Richards, K.E.: Biology and molecular biology of furoviruses. Adv. Virus Res. 36: 1-32 (1989).

Giunchedi, L.; Langenberg, W.G.; Marani, F.: Appearance of beet necrotic yellow vein virus (BNYVV) in host cells. Phytopath. Mediterr. 20: 112-116 (1981).

Hsu, Y.H.; Brakke, M.K.: Cell-free translation of soil-borne wheat mosaic virus RNAs. Virology 143: 272-279 (1985).

Hsu, Y.H.; Brakke, M.K.: Sequence relationships among soil-borne wheat mosaic virus RNA species and terminal structures of RNA II. J. gen. Virol. 66: 915-919 (1985).

Kallender, H.; Buck, K.W.; Brunt, A.A.: Association of three RNA molecules with potato mop-top virus. Neth. J. Pl. Path. 96: 47-50 (1990).

Kendall, T.L.; Langenberg, W.G.; Lommel, S.A.: Molecular characterization of sorghum chlorotic spot virus, a proposed furovirus. J. gen. Virol. 69: 2335-2345 (1988).

Lemaire, O.; Merdinoglu, D.; Valentin, P.; Putz, C.; Ziegler-Graff, V.; Guilley, H.; Jonard, G.; Richards, K.: Effect of beet necrotic yellow vein virus RNA composition on transmission by Polymyxa betae. Virology 162:232-235 (1988).

Mayo, M.A.; Reddy, D.V.R.: Translation products of RNA from Indian peanut clump virus. J. gen. Virol. 66: 1347-1351 (1985).

Randles, J.W.; Rohde, W.: Nicotiana velutina mosaic virus: evidence for a bipartite genome comprising $3 \mathrm{~Kb}$ and $8 \mathrm{~Kb}$ RNAs. J. Gen. Virol. 71: 1019-1027 (1990).

Reddy, D.V.R.; Robinson, D.J.; Roberts, I.M.; Harrison, B.D.: Genome properties and relationships of Indian peanut clump virus. J. gen. Virol. 66: 2011-2016 (1985).

Russo, M.; Martelli, G.P.; di Franco, A.: The fine structure of local lesions of beet necrotic yellow vein virus in Chenopodium amaranticolor. Phys. Pl. Path. 19: 237-242 (1981).

Shirako, Y.; Brakke, M.K.: Two purified RNAs of soil-borne wheat mosaic virus are needed for infection. J. gen. Virol. 65:119-127 (1984).

Shirako, Y.; Brakke, M.K.: Spontaneous deletion mutation of soil-borne wheat mosaic virus RNA II. J. gen. Virol. 65: 855-858 (1984).

Shirako, Y.; Ehara, Y.: Comparison of the in vitro translation products of wild-type and a deletion mutant of soil-borne wheat mosaic virus. J. gen. Virol. 67: 1237-1245 (1986).

Tamada, T.; Abe, H.: Evidence that beet necrotic yellow vein virus RNA-4 is essential for efficient transmission by the fungus Polymyxa betae. J. gen. Virol. 70: 3391-3398 (1989).

Ziegler, V.; Richards, K.; Guilley, H.; Jonard, G.; Putz, C.: Cell-free translation of beet necrotic yellow vein virus: readthrough of the coat protein cistron. J. gen. Virol. 66:2079-2087 (1985).

Ziegler-Graff, V.; Bouzoubaa, S.; Jupin, I.; Guilley, H.; Jonard, G.; Richards, K.: Biologically active transcripts of beet necrotic yellow vein virus RNA-3 and RNA-4. J. gen. Virol. 69: 2347-2357 (1988). 


\begin{tabular}{|lll|}
\hline GROUP & $\begin{array}{l}\text { TOBACCO RATTLE } \\
\text { VIRUS GROUP }\end{array}$ & TOBRA VIRUS \\
\hline
\end{tabular}

Revised by D.J. Robinson

\begin{tabular}{lll}
\hline TYPE MEMBER & $\begin{array}{l}\text { TOBACCO RATTLE VIRUS } \\
\text { (TRV) (PRN ISOLATE) (346) }\end{array}$ & - \\
\hline
\end{tabular}

Morphology

\section{Properties of The Virus Particle}

Physicochemical MWs $=48-50 \times 10^{6}(\mathrm{~L})$ and $11-29 \times 10^{6}(\mathrm{~S}) ; \mathrm{S}_{20 \mathrm{w}}=$ properties $286-306(\mathrm{~L})$ and $155-245(\mathrm{~S})$; buoyant density in $\mathrm{CsCl}=$ $1.306-1.324 \mathrm{~g} / \mathrm{cm}^{3}$. Particles stable.

Nucleic acid Two strands of linear positive-sense ssRNA with MWs $\approx$ $2.4 \times 10^{6}$ (RNA-1) and 0.6-1.4 × $10^{6}$ (RNA-2), the size of the latter depending on the isolate; $5^{\prime}$ terminus has the sequence $m^{7} G^{5}$ ppp $^{5}$ Ap... RNA-1 is infective; RNA-2 is not infective but it contains the cistron for the capsid protein; both RNAs are required for production of progeny long (L) and short (S) particles. RNA-2 sequences differ considerably between isolates of each member virus and also between the three member viruses. In contrast, RNA1 sequences of different isolates of each member virus are substantially similar, though entirely different from those of other member viruses.

Protein One coat polypeptide; MW $\approx 22 \times 10^{3}$.

Lipid None reported.

Carbohydrate None reported.

Antigenic properties

Moderately immunogenic; considerable antigenic heterogeneity between isolates. Little or no serological relationship between members.

\section{REPLICATION}

Accumulation of virus particles sensitive to cycloheximide but not to chloramphenicol, suggesting cytoplasmic ribosomes are involved in viral protein synthesis; L 
particles accumulate in early part of infection cycle, whereas S particles tend to accumulate in the later stages; isolates unable to produce nucleoprotein particles (NM isolates) are obtained from inocula containing only $\mathrm{L}$ particles; such isolates are also found in naturally infected plants.

\section{Biological Aspects}

Host range Wide, including monocotyledonous and dicotyledonous families.

Transmission Primarily by nematodes (Paratrichodorus and Trichodorus spp.) in which the virus may persist, but is not retained through the moult; there is no evidence of replication within the vector. Also transmitted by seed and experimentally by mechanical inoculation, but with difficulty for NM isolates.

\section{SEQUENCE SIMILARITIES WITH OTHER VIRUS GROUPS OR FAMILIES}

Some non-structural proteins synthesized by tobacco rattle virus share sequence similarities with non-structural proteins of some other RNA plant viruses [e.g. tripartite virus (alfalfa mosaic, brome mosaic and cucumber mosaic viruses) and a monopartite plant (carnation mottle virus)] and animal viruses [e.g. Sindbis virus].

\section{OTHER MEMBERS}

Pea early-browning (120)

Pepper ringspot

Derivation of tobra: sigla from tobacco rattle.

Name

\section{REFERENCES}

Goldbach, R.: Genome similarities between plant and animal RNA viruses. Microbiol. Sci. 4:197-202 (1987).

Harrison, B.D.; Robinson, D.J.: The tobraviruses. Adv. Virus Res. 23:25-77 (1978).

Harrison, B.D.; Robinson, D.J.: Tobraviruses; In Kurstak, E. (ed.), Handbook of Plant Virus Infections and Comparative Diagnosis, pp. 515-540. (Elsevier/North Holland, Amsterdam, 1981).

Harrison, B.D.; Robinson, D.J.: Tobraviruses; In van Regenmortel, M.H.V.; Fraenkel-Conrat, H. (eds.), The Plant Viruses, The rod-shaped plant viruses, Vol. 2, pp. 339-369 (Plenum Press, New York, 1986).

Robinson, D.J.; Harrison, B.D.: Unequal variation in the two genome parts of tobraviruses and evidence for the existence of three separate viruses. J. gen. Virol. 66:171-176 (1985). 


\begin{tabular}{|lll|}
\hline GROUP & BROME MOSAIC & BROMOVIRUS \\
& VIRUS GROUP (215) & \\
\hline
\end{tabular}

Revised by E.P. Rybicki

\begin{tabular}{lll}
\hline TYPE MEMBER & $\begin{array}{l}\text { BROME MOSAIC VIRUS } \\
(\text { BMV })(3 ; 180)\end{array}$ & - \\
\hline
\end{tabular}

Morphology

\section{Properties of the Virus Particle}

Polyhedral particles $\approx 26 \mathrm{~nm}$ in diameter, with icosahedral $\mathrm{T}=3$ surface lattice symmetry. Although all particles have approximately the same $S_{20 \mathrm{w}}(85)$, three different particles exist, one containing one molecule of RNA-1, one containing one molecule of RNA 2 and one containing one molecule each of RNA 3 and RNA 4.

Physicochemical properties

$\mathrm{MW} \approx 4.6 \times 10^{6} ; \mathrm{S}_{20 \mathrm{w}} \approx 85$; buoyant density in $\mathrm{CsCl} \approx$ $1.35 \mathrm{~g} / \mathrm{cm}^{3}$. Particles swell reversibly in presence of $\mathrm{Ca}^{2+}$ or $\mathrm{Mg}^{2+}$ or $\mathrm{pH}$ increase above 7.0, with concomitant changes in capsid conformation; pronounced loss of stability; salt-, detergent-, protease- and ribonucleasesusceptible in swollen form.

Nucleic acid

Three genomic molecules of linear positive-sense ssRNA of $3.2 \mathrm{~kb}$ (RNA 1), $2.8 \mathrm{~kb}$ (RNA 2) and $2.1 \mathrm{~kb}$ (RNA 3); $0.8 \mathrm{~kb}$ coat protein mRNA (RNA 4) is also encapsidated. 5'-termini capped $\left(\mathrm{m}^{7} \mathrm{G}^{5} \mathrm{ppp}^{5} \mathrm{Gp}\right.$...); 3'-termini have a tRNA-like structure which accepts tyrosine in vivo and in vitro; however, encapsidated RNA is not aminoacylated.

Protein

Single coat polypeptide, MW $\approx 20 \times 10^{3}, 189$ amino acids. Highly basic $\mathrm{NH}_{2}$-terminus $(\approx 25$ residues); often partially degraded in vivo and in vitro.

Lipid None reported.

Carbohydrate None reported.

Antigenic properties

Moderately poor immunogens unless stabilised by glutaraldehyde or formaldehyde cross-linking. Serological reactions of virions best performed below $\mathrm{pH}$ 7.0; serological differences between compact and swollen forms, and artificial empty capsids and intact virions. Moderate to distant serological relationships between all members. 


\section{REPLICATION}

RNAs of BMV, cowpea chlorotic mottle and broad bean mottle viruses can be in vitro translated into 4 major proteins: RNAs 1 and 2 are monocistronic and encode proteins of $\mathrm{MW} \approx 110$ and $\approx 95 \times 10^{3}$ respectively; dicistronic RNA 3 encodes proteins of $\mathrm{MW} \approx 35$ (3a) and $\approx 20 \times 10^{3}$ (coat protein), 3a protein only produced in vitro; RNA 4 is a subgenomic monocistronic mRNA for coat protein. Genomic RNAs replicate via full-length complementary (-) sense RNA, in membrane-associated replicase complex containing RNA 1 and RNA 2 encoded proteins. Replicase recognition of genomic RNA depends upon integrity of tRNA-like structure; 3'-adenylate residue is added autocatalytically; 3'-terminal sequence is apparently telomeric. In vitro transcripts of cloned cDNA copies of BMV are infectious. Recombination can occur during replication to restore native sequences. BMV RNA 3 contains an intercistronic variable-length oligo(A) tract which is restored in a template-independent manner if deleted. RNA 4 arises by internal initiation of replicase on (-)strand of RNA 3 using a specific promoter sequence; this RNA is not replicated. An intact coat protein gene, especially the $\mathrm{NH}_{2}$-terminal 25 amino acids, is necessary for RNA encapsidation, and $3 \mathrm{a}$ and coat proteins are necessary for cell-to-cell movement. Virions assemble in cytoplasm, and granular inclusions are found, sometimes in crystalline arrays. Particles are found in both cytoplasm and nuclei of old infected cells. The viruses do not appear to be tissue-specific.

\section{Biological ASPECTS}

Host range

Transmission
Narrow.

Some members transmitted by beetles. Readily transmissible experimentally by mechanical inoculation.

\section{SEQUENCE SIMILARITIES WITH OTHER VIRUS GROUPS OR FAMILIES}

Predicted amino acid sequences from single ORFs of RNA 1 and RNA 2 share significant sequence homology with analogous sequences from cucumoviruses and alfalfa mosaic virus, and with replication-associated proteins produced by tobamoviruses, tobraviruses and togaviruses: this would put the bromoviruses in the Sindbis-like virus "superfamily". The RNA 1 ORF contains a putative nucleotide binding domain; the RNA 2 ORF contains the putative $(+)$ strand RNA virus polymerase domain. Distant 
similarities can be seen between the 3a protein (movement protein) sequences of bromoviruses and cucumoviruses, and more distantly between these and ilarviruses and alfalfa mosaic virus.

\section{OTHER MEMBERS}

Broad bean mottle (101)

Cassia yellow blotch

Cowpea chlorotic mottle (49)

Melandrium yellow fleck (236)

Spring beauty latent

Derivation of Name bromo: sigla from brome mosaic; also, from plant generic name Bromus, brome.

\section{REFERENCES}

Ahlquist, P.; Dasgupta, R.; Kaesberg, P.: Nucleotide sequence of the brome mosaic virus genome and its implications for viral replication. J. Mol. Biol. 172:369-383 (1984).

Ahlquist, P.; French, R.; Janda, M.; Loesch-Fries, L.S.: Multicomponent RNA plant virus infection derived from cloned viral cDNA. Proc. Natl. Acad. Sci. USA $81: 7066-7070$ (1984).

Allison, R.F.; Janda, M.; Ahlquist, P.: Sequence of cowpea chlorotic mottle virus RNAs 2 and 3 and evidence of a recombination event during bromovirus evolution. Virology 172 : 321-330 (1989).

Allison, R.; Thompson, C.; Ahlquist, P.: Regeneration of a functional RNA virus genome by recombination between deletion mutants and requirement for cowpea chlorotic mottle virus 3a and coat genes for systemic infection. Proc. Natl. Acad. Sci. USA 87: 18201824 (1990).

Bujarski, J.J.; Kaesberg, P.: Genetic recombination between RNA components of a multipartite plant virus. Nature 321: 528-531 (1986).

Dale, J.L.; Gibbs, A.J.; Behncken, G.M.: Cassia yellow blotch virus: a new bromovirus from an Australian native legume, Cassia pleurocarpa. J. gen. Virol. 65:281-288 (1984).

Davies, J.W.; Verduin, B.J.M.: In vitro synthesis of cowpea chlorotic mottle virus polypeptides. J. gen. Virol. 44:545-549 (1979).

Francki, R.I.B.: The Plant Viruses, Polyhedral Virions with Tripartite Genomes. vol. 1 (Plenum Press, New York, London, 1985).

Francki, R.I.B.; Milne, R.G.; Hatta, T.: Bromovirus group; In Atlas of Plant Viruses, Vol. II, pp. 69-80. (CRC Press, Boca Raton, Fl., 1985).

Goldbach, R.: Genome similarities between plant and animal RNA viruses. Microbiol. Sci. 4:197-202 (1987).

Karpova, O.V.; Tyulkina, L.G.; Atabekov, K.J.; Rodionova, N.P.; Atabekov, J.G.: Deletion of the intercistronic poly (A) tract from brome mosaic virus RNA 3 by ribonuclease $H$ and its restoration in progeny of the religated RNA 3. J. gen. Virol. 70: 2287-2297 (1989).

Lane, L.C.: Bromoviruses; In Kurstak, E. (ed.), Handbook of Plant Virus Infections and Comparative Diagnosis, pp. 333-376 (Elsevier/North Holland, Amsterdam, 1981).

Loesch-Fries, L.S.; Hall, T.C.: Synthesis, accumulation and encapsidation of individual brome mosaic virus RNA components in barley protoplasts. J. gen. Virol. 47:323-332 (1980). 
Miller, W.A.; Bujarski, J.J.; Dreher, T.W.; Hall, T.C.: Minus-strand initiation by brome mosaic virus replicase within the 3' tRNA-like structure of native and modified RNA templates. J. Mol. Biol. 187: 537-546 (1986).

Miller, W.A.; Dreher, T.W.; Hall, T.C.: Synthesis of brome mosaic virus subgenomic RNA in vitro by internal initiation on (-) sense genomic RNA. Nature 313:68-70 (1985).

Pfeiffer, P.: Changes in the organization of bromegrass mosaic virus in response to cation binding as probed by changes in susceptibility to degradative enzymes. Virology 102:54-61 (1980).

Rao, A.L.N.; Dreher, T.W.; Marsh, L.E.; Hall, T.C.: Telomeric function of the transfer RNAlike structure of brome mosaic virus RNA. Proc. Natl. Acad. Sci. USA 86: 5335-5339 (1989).

Rao, A.L.N.; Hall, T.C.: Requirement for a viral trans-acting factor encoded by brome mosaic virus RNA 2 provides strong selection in vivo for functional recombinants. J. Virol. 64: 2437-2441 (1990).

Roenhorst, J.W.; van Lent, J.W.M.; Verduin, B.J.M.: Binding of cowpea chlorotic mottle virus to cowpea protoplast and relation of binding to virus entry and infection. Virology 164: 91-98 (1988).

Rybicki, E.P.; von Wechmar, M.B.: The serology of the bromoviruses. I. Serological interrelationships of the bromoviruses. Virology 109:391-402 (1981).

Sacher, R.; Ahlquist, P.: Effects of deletions in the N-terminal basic arm of brome mosaic virus coat protein on RNA packaging and systemic infection. J. Virol. 63: 4545-4552 (1989).

Valverde, R.A.: Properties of the RNA and coat protein of spring beauty latent virus and comparison with those of four bromoviruses. Phytopathology 79: 1214-1215 (1989).

Valverde, R.A.: Spring beauty latent virus: a new member of the bromovirus group. Phytopathology 75: 395-398 (1985). 


\begin{tabular}{|lll|}
\hline GROUP & $\begin{array}{l}\text { CUCUMBER MOSAIC } \\
\text { VIRUS GROUP }\end{array}$ & CUCUMOVIRUS \\
\hline
\end{tabular}

Revised by H. Lot

\begin{tabular}{lll}
\hline TYPE MEMBER & $\begin{array}{l}\text { CUCUMBER MOSAIC VIRUS } \\
\text { (CMV) (S ISOLATE) }(1 ; 213)\end{array}$ & - \\
\hline
\end{tabular}

\section{Properties of the Virus Particle}

Morphology

Physicochemical properties

Nucleic acid

Protein

Lipid

Carbohydrate

Antigenic properties
Polyhedral particles $\approx 29 \mathrm{~nm}$ in diameter, with $\mathrm{T}=3$ surface lattice symmetry. Although all particles have approximately the same $S_{20 \mathrm{w}}$, three particles exist, one containing one molecule of RNA-1, one containing one molecule of RNA-2 and one containing one molecule each of RNA-3 and RNA-4.

$\mathrm{MW} \approx 6 \times 10^{6} ; \mathrm{S}_{20 \mathrm{w}} \approx 99$; buoyant density in $\mathrm{CsCl} \approx$ $1.37 \mathrm{~g} / \mathrm{cm}^{3}$; particles readily disrupted in neutral chloride salts and by SDS; particles sensitive to RNAse.

Three genomic molecules of the linear positive-sense ssRNA; RNA-1 (3357-3389 nt), RNA-2 (3035-3050 nt), RNA-3 (2197-2216 nt); a sub-genomic coat protein mRNA (RNA-4, $1027 \mathrm{nt}$ ) is also encapsidated. Satellite RNA (333-393 according to isolates) which depends on genomic RNA for replication and encapsidation, occurs in some CMV and peanut stunt virus isolates. There is little sequence similarity between the satellite and genomic RNAs. 5' termini of all four RNAs have the sequence: $\mathrm{m}^{7} \mathrm{Gppp} .$. The $3^{\prime}$ termini of all RNAs contain long (200 nt) regions of sequence similarity characteristic of each member; the termini are not poly-adenylated but they can be aminoacylated by tyrosine.

Single coat polypeptide, $\mathrm{MW} \approx 26.2 \times 10^{3}$.

None reported.

None reported.

Poor immunogens. Serological reactions complicated by sensitivity of virus particles to salts. Distant serological relationships among members.

\section{REPLICATION}

The RNAs of CMV can each be translated in vitro to yield 4 major proteins; RNAs 1, 2, 3 and 4 code for proteins of 
$\mathrm{MW}=111,94$, and $30 \times 10^{3}$ and coat protein, respectively. RNAs replicate via corresponding negativesense strands. Coat protein readily detected in infected cells and protoplasts but other translation products have not been found. Virus particles assemble in the cytoplasm and accumulate there as scattered particles. Sometimes, virus particles also occur in nuclei and vacuoles, rarely forming crystals. Chloroplasts with extensively modified internal structure are characteristic of cells infected by some virus strains. Small vesicles associated with the tonoplast may be the sites of RNA replication.

\section{Biological ASPECTS}

Host range Type member has wide host range $(\approx 1000$ species); other members have more restricted host ranges.

Transmission Seed transmission in several host plants. Transmitted by aphids in non-persistent manner. Readily transmissible experimentally by mechanical inoculation.

\section{SEQUENCE SIMILARITIES WITH OTHER VIRUS GROUPS OR FAMILIES}

Some putative non-structural proteins coded for by RNAs 1 and 2 share sequence similarities with similar proteins of other plant viruses [e.g. tripartite genome viruses (alfalfa mosaic, brome mosaic), a bipartite genome virus (tobacco rattle), monopartite genome viruses (carnation mottle and tobacco mosaic)], and Sindbis virus, a RNA animal virus with a monopartite genome.

\section{OTHER MEMBERS}

Peanut stunt (91) (= Robinia mosaic) (65)

Tomato aspermy (79)

\section{Probable member}

Cowpea ringspot 


\section{REFERENCES}

Davies, C.; Symons, R.H.: Further implications for the evolutionary relationships between tripartite plant viruses based on cucumber mosaic virus RNA 3. Virology 165: 216-224 (1988).

Francki, R.I.B.; Milne, R.G.; Hatta, T.: Cucumovirus group; In Atlas of Plant Viruses, vol. II, pp. 53-68 (CRC Press, Boca Raton, Fl., 1985).

Goldbach, R.: Genome similarities between plant and animal RNA viruses. Microbiol. Sci. 4:197-202 (1987).

Hull, R.; Maule, A.J.: Virus Multiplication; In Francki, R.I.B. (ed.), The Plant Viruses, Polyhedral Virions with Tripartite Genomes, Vol. 1, pp. 83-115 (Plenum Press, New York, 1985).

Kaper, J.M.; Waterworth, H.E.: Cucumoviruses; In Kurstak, E. (ed.), Handbook of Plant Virus Infections and Comparative Diagnosis, pp. 257-332 (Elsevier/North Holland, Amsterdam, 1981).

Owen, J.; Shintaku, M.; Aeschleman, P.; Ben Tahar, S.; Palukaitis, P.: Nucleotide sequence and evolutionary relationships of cucumber mosaic virus (CMV) strains: CMV RNA 3. (In Press) (1990).

Phatak, H.C.; Diaz-Ruiz, J.R.; Hull, R.: Cowpea ringspot virus: a seed transmitted cucumovirus. Phytopath. Z. 87:132-142 (1976).

Rezaian, M.A.; Williams, R.H.V.; Gordon, K.H.J.; Gould, A.R.; Symons, R.H.: Nucleotide sequence of cucumber mosaic virus RNA 2 reveals a translation product significantly homologous to corresponding proteins of other viruses. Eur. J. Biochem. 143: 277-284 (1984).

Rezaian, M.A.; Williams, R.H.V.; Symons, R.H.: Nucleotide sequence of cucumber mosaic virus RNA 1: Presence of a sequence complementary to part of the viral satellite RNA and homologies with other viral RNAs. Eur. J. Biochem. 150:331-339 (1985).

Rizzo, T.M.; Palukaitis, P.: Nucleotide sequence and evolutionary relationships of cucumber mosaic virus (CMV) strains: CMV RNA 1. J. gen. Virol. 70: 1-11 (1989).

Rizzo, T.M.; Palukaitis, P.: Nucleotide sequences and evolutionary relationships of cucumber mosaic virus (CMV) strains: CMV RNA 2. J. gen. Virol. 69: 1777-1787 (1988).

Symons, R.H.: Viral Genome Structure; In Francki, R.I.B. (ed.), The Plant Viruses, Polyhedral Virions with Tripartite Genomes, Vol. 1, pp. 57-81 (Plenum Press, New York , 1985). 
Revised by R.I.Hamilton

\begin{tabular}{lll}
\hline TYPE MEMBER & $\begin{array}{l}\text { TOBACCO STREAK VIRUS } \\
(\mathrm{TSV})(44)\end{array}$ & - \\
\hline
\end{tabular}

\section{Properties of The Virus Particle}

Morphology Particles are quasi-isometric or occasionally bacilliform. Particles of different components, although differing in size, are mostly $26-35 \mathrm{~nm}$ in diameter.

Physicochemical Several particle types, $S_{20 \mathrm{w}}=80-120$; buoyant density of properties all particle types $\approx 1.36 \mathrm{~g} / \mathrm{cm}^{3}$ in $\mathrm{CsCl}$; particles readily disrupted in neutral chloride salts and by SDS.

Nucleic acid

Three molecules of linear positive-sense ssRNA; MW $\approx$ 1.1 (RNA-1), 0.9 (RNA-2) and 0.7 (RNA-3) x 106; coat protein mRNA of $\mathrm{MW} \approx 0.3 \times 10^{6}$ (RNA-4), a subgenomic fragment of RNA-3 is also encapsidated.

Protein

\section{Lipid}

Carbohydrate

Antigenic properties

\section{Host range}

Single coat polypeptide, $\mathrm{MW} \approx 25 \times 10^{3}$.

None reported.

None reported.

Weakly to moderately immunogenic. Serological relationship among some members. Several sub-groups (I-X) with type member and closely related strains as the only members of subgroup I.

\section{REPLICATION}

Besides RNAs 1-3, coat protein or RNA-4 is required for infectivity. Coat protein of most ilarviruses (and also of alfalfa mosaic virus) are interchangeable in this respect. For some members it has been shown that RNAs 1 and 2 can be translated in vitro into proteins of MW corresponding to the total genetic information present in these RNAs. RNA-3-directs the synthesis of protein, MW $\approx 34 \times 10^{3}$, and RNA-4 directs the synthesis of coat protein.

\section{Biological Aspects}

Wide. 
Transmission Some viruses transmitted by seeds and by pollen to flowerbearing plants. Thrips may be involved in pollen transmission. Readily transmissible experimentally by mechanical inoculation.

\section{SEQUENCE SIMILARITIES WITH OTHER VIRUS GROUPS OR FAMILIES}

The $\mathrm{MW} \approx 34 \times 10^{3}$ protein directed by tobacco streak virus RNA-3 shares some sequence similarity with the $\mathrm{MW} \approx 35 \times 10^{3}$ protein directed by alfalfa mosaic virus RNA-3.

\section{OTHER MEMbERS}

Subgroup II

Asparagus virus II (288)

Citrus leaf rugose (164)

Citrus variegation (164)

Elm mottle (139)

Tulare apple mosaic (42)

Subgroup III

Prunus necrotic ringspot (5) (= some isolates of rose mosaic)

Blueberry scorch

Cherry rugose

Hop C

Apple mosaic (83) (= some isolates of rose mosaic)

Danish plum line pattern

Hop A

Subgroup IV

Prune dwarf (19)

Subgroup V

American plum line pattern (280)

Subgroup VI

Spinach latent (281)

Subgroup VII

Lilac ring mottle (201)

Subgroup VIII

Hydrangea mosaic

Subgroup IX

Humulus japonicus

Subgroup X

Parietaria mottle 


\section{REFERENCES}

Adams, A.N.; Clark, M.F.; Barbara, D.J.: Host range, purification and some properties of a new ilarvirus from Humulus japonicus. Ann. appl. Biol. 114: 497-508 (1989).

Caciagli, P.; Boccardo, G.; Lovisolo, O.: Parietaria mottle virus, a possible new ilarvirus from Parietaria officinalis (Urticaceae). Plant Pathol. 38: 577-584 (1989).

Cornelissen, B.J.C.; Janssen, H.; Zuidema, D.; Bol, J.F.: Complete nucleotide sequence of tobacco streak virus RNA 3. Nuc. Acids Res. 12: 2427-2437 (1984).

Francki, R.I.B.: The Plant Viruses, Polyhedral virions with tripartite genomes, Vol. 1 (Plenum Press, New York, 1985).

Fulton, R.W.: Ilar-like characteristics of American plum line pattern virus and its serological detection in Prunus. Phytopathology 72:1345-1348 (1982).

Fulton, R.W.: Ilarviruses; In Kurstak, E. (ed.), Handbook of Plant Virus Infections and Comparative Diagnosis, pp. 377-413 (Elsevier/North Holland, Amsterdam, 1981).

Huttinga, H.; Mosch, W.H.M.: Lilac ring mottle virus: a coat protein-dependent virus with a tripartite genome. Acta Hort. 59:113-118 (1976).

MacDonald, S.G.; Martin, R.R.; Bristow, P.R.: Characterization of an ilarvirus associated with blueberry scorch disease. (Submitted).

Sdoodee, R.; Teakle, D.S.: Transmission of tobacco streak virus by Thrips tabaci: a new method of plant virus transmission. Plant Pathology 36: 377-380 (1987).

Thomas, B.J.; Barton, R.J.; Tuszynski, A.: Hydrangea mosaic virus, a new ilarvirus from Hydrangea macrophylla (Saxifragaceae). Ann. appl. Biol. 103:261-270 (1983). 


\begin{tabular}{llc}
\hline GROUP & ALFALFA MOSAIC VIRUS GROUP & - \\
& & Revised by R. Goldbach \\
\hline TYPE MEMBER & $\begin{array}{l}\text { ALFALFA MOSAIC VIRUS } \\
(\text { AMV)(46;229) }\end{array}$ & - \\
\hline
\end{tabular}

\section{Properties of the Virus Particle}

Morphology Bacilliform particles, 56 x $18 \mathrm{~nm}(\mathrm{~B}), 43 \times 18 \mathrm{~nm}(\mathrm{M}), 35$ $\mathrm{x} 18 \mathrm{~nm}(\mathrm{~Tb})$ and a particle (Ta) that occurs in both bacilliform (Ta-b; $30 \times 18 \mathrm{~nm}$ ) and ellipsoidal shape (Ta-t). The three largest particles contain a single RNA molecule each: RNA-1 (B), RNA-2 (M), RNA-3 (Tb); Ta contains two molecules of RNA-4.

Physicochemical MW of particles (B, M, Tb and Ta) range from 6.9 to $3.5 \mathrm{x}$ properties $10^{6} ; S_{20 \mathrm{w}} \approx 94(\mathrm{~B}), 82(\mathrm{M}), 73(\mathrm{~Tb})$ and $66(\mathrm{Ta})$; buoyant density in $\mathrm{Cs}_{2} \mathrm{SO}_{4} \approx 1.28 \mathrm{~g} / \mathrm{cm}^{3}$, in $\mathrm{CsCl}$ (after fixation) $\approx 1.37 \mathrm{~g} / \mathrm{cm}^{3}$ (components differ slightly in banding densities). RNA content of all particle species between $15-17 \%$. Particles disrupted in neutral chloride salts; sensitive to ribonuclease at $\mathrm{pH} \mathrm{6-7,} \mathrm{but} \mathrm{do} \mathrm{not}$ appear to swell.

Nucleic acid

Three molecules of linear positive-sense ssRNA of 3644 nucleotides (RNA-1), 2593 nucleotides (RNA-2) and 2142 nucleotides (RNA-3); a 881 nucleotide mRNA (RNA-4), encoding the coat protein, is also encapsidated. 5 ' termini of the four RNAs have the sequence of $m^{7} \mathrm{G}^{5} \mathrm{ppp}^{5^{1}} \mathrm{Gp}$. The last 145 nucleotides at the 3'-termini of all four RNA species are similar.

Protein One coat polypeptide, $\mathrm{MW} \approx 24 \times 10^{3}$. Some degradation of the $\mathrm{N}$ terminus may occur in vitro.

\section{Lipid None reported.}

Carbohydrate None reported.

Antigenic properties

Poor immunogens. Biologically distinct strains are antigenically similar.

\section{REPLICATION}

Besides RNAs-1, -2 and -3 , coat protein or RNA-4 is required for infectivity. Coat proteins from ilarviruses are also able to activate the AMV genome. RNAs-1, -2 , and 
-3 encode non-structural proteins of MWs $=126(\mathrm{P} 1), 90$ (P2) and $32 \times 10^{3}$ (P3), respectively. Coat protein is translated from a subgenomic mRNA (RNA-4) derived from RNA-3. All four proteins are produced by in vitro translation of these RNAs and have been detected in infected leaves and inoculated protoplasts. P1 and P2 are involved in viral RNA synthesis. P3 is the putative transport protein, involved in cell-to-cell movement of virus. Virus particles accumulate in the cytoplasm and sometimes in vacuoles, either scattered or as whorled aggregates.

\section{Biological ASPECtS}

Host range

Transmission
Wide host range, including many leguminous plants.

Seed transmission in some plants. Transmitted by aphids in a nonpersistent manner. Readily transmissible experimentally by mechanical inoculation.

\section{SEQUENCE SIMILARITIES WITH OTHER VIRUS GROUPS OR FAMILIES}

The proteins directed by RNA-1 and RNA-2 show significant sequence similarity with the proteins directed by RNA-1 and RNA-2 of ilar-, bromo-, cucumo-, tobamoand tobraviruses as well as with the proteins directed by the genomic RNA of alphaviruses. AMV, bromo- and cucumoviruses are, moreover, very similar in tripartite genome organization.

\section{REFERENCES}

Berna, A.; Briand, J.-P.; Stussi-Garaud, C.; Godefroy-Colburn, T.: Kinetics of accumulation of the three non-structural proteins of alfalfa mosaic virus in tobacco plants. J. gen. Virol. 67:1135-1147 (1986).

Cornelissen, B.J.C.; Bol, J.F.: Homology between the proteins encoded by tobacco mosaic virus and two tricornaviruses. Plant Mol. Biol. 3:379-384 (1984).

Francki, R.I.B.: The Plant Viruses, Polyhedral virions with tripartite genomes, Vol. 1 (Plenum Press, London, New York, 1985).

Goldbach, R.: Genome similarities between plant and animal RNA viruses. Microbiol. Sci. 4:197-202 (1987).

Goldbach, R.; Wellink, J.: Evolution of plus-strand RNA viruses. Intervirology 29: 260-267 (1988).

Haseloff, J.; Goelet, P.; Zimmern, D.; Ahlquist, P.; Dasgupta, R.; Kaesberg, P.: Striking similarities in amino acid sequence among nonstructural proteins encoded by RNA viruses that have dissimilar genomic organization. Proc. Natl. Acad. Sci. USA $81: 4358-4362$ (1984). 
Jaspars, E.M.J.: Interactions of alfalfa mosaic virus nucleic acid and protein. In Davies, J.W. (ed.), Molecular Plant Virology, Vol. 1, pp. 155-221 (CRC Press, Boca Raton, Fl., 1985).

Stussi-Garaud, C.; Garaud, J.-C.; Berna, A.; Godefroy-Colburn, T.: In situ location of an alfalfa mosaic virus non-structural protein in plant cell walls: Correlation with virus transport. J. gen. Virol. 68: 1779-1784 (1987).

van Pelt-Heerschap, H.; Verbeek, H.; Huisman, M.J.; Loesch-Fries, L.S.; van Vloten-Doting, L.: Non-structural proteins and RNAs of alfalfa mosaic virus synthesized in tobacco and cowpea protoplasts. Virology 161:190-197 (1987).

van Vloten-Doting, L.; Francki, R.I.B.; Fulton, R.W.; Kaper, J.M.; Lane, L.C.: Tricornaviridae - a proposed family of plant viruses with tripartite, single-stranded RNA genomes. Intervirology 15:198-203 (1981). 
GROUP

BARLEY STRIPE MOSAIC

HORDEIVIRUS VIRUS GROUP

Revised by R.I. Hamilton

\begin{tabular}{lll}
\hline TYPE MEMBER & BARLEY STRIPE MOSAIC & - \\
& VIRUS (BSMV) $(68 ; 344)$ & \\
\hline
\end{tabular}

\section{Properties of The Virus Particle}

Morphology Elongated rigid particles about 20 x 110-150 nm; helically symmetrical with pitch $\approx 2.5 \mathrm{~nm}$.

Physicochemical properties

Nucleic acid

Protein

\section{Lipid}

Carbohydrate

Antigenic properties
Major sedimenting species $S_{20 w}=182-193 S$; other species $S_{20 \mathrm{w}}=165-200 \mathrm{~S}$, depending on the strain.

Three molecules of positive sense ssRNA of $3768 \mathrm{nt}$ (RNA $\alpha$ ), $3289 \mathrm{nt}$ (RNA $\beta$ ) and 3164 (RNA $\gamma$ ) are present in the type strain; other strains contain similar RNAs. In the Argentine mild strain, a fourth RNA arises from a deletion in RNA. Other RNAs of 800-2900 nt are found, depending on the strain and may represent subgenomic RNAs. There is no appreciable sequence similarity between RNA $\alpha$ and the other genomic RNAs of BSMV, and none between those of BSMV and poa semilatent virus. Each RNA has $\mathrm{m}^{7} \mathrm{GpppGUA}$ at its $5^{1}$-end and a poly A tract of 8-40 nt followed by a 236-238 nt tRNAlike structure at its 3 '-end which accepts tyrosine.

Single polypeptide, $\mathrm{MW}=22.15 \times 10^{6}$.

None reported.

Capsid protein is reported to be glycosylated.

Efficient immunogens. Members are distantly related serologically.

\section{REPLICATION}

Virus particles accumulate in both cytoplasm and nuclei, most being in the cytoplasm. RF RNAs corresponding to all viral ssRNAs can be isolated from infected plants. RNA $\alpha$ of the type strain has an ORF which is translated in vitro to produce a protein, $\mathrm{MW} \approx 129.6 \times 10^{3}$, possibly the virus replicase. RNA $\beta$ is translated in vivo into capsid protein $(\beta a), M W \approx 22.15 \times 10^{3}$ and a second one $(\beta b)$, $\mathrm{MW} \approx 58.1 \times 10^{3}$; two other ORFs code for proteins, MW 
$\approx 17.4$ and $14.1 \times 10^{3}$, the functions of which are unknown. RNA $\gamma$ contains ORFs for two proteins, $M W \approx$ 87.3 and $17.2 \times 10^{3}$ whose functions are also unknown.

\section{Biological ASPECTS}

Host range

Narrow host range, mostly among Gramineae.

Transmission

By mechanical inoculation and through seed. No vector is known.

\section{SEQUENCE SIMILARITIES WITH OTHER VIRUS GROUPS OR FAMILIES}

There are similarities in genome organization with that of beet necrotic yellows virus (furovirus group), and potato virus $\mathrm{X}$ and white clover mosaic virus (potexvirus group).

\section{OTHER MEMBERS}

Anthoxanthum latent blanching Lychnis ringspot Poa semilatent

Derivation of hordei: from Latin hordeum, 'barley'. Name

\section{REFERENCES}

Carroll, T.W.: Hordeiviruses: biology and pathology. In van Regenmortel, M.H.V.; Fraenkel-Conrat, H. (eds.), The Plant Viruses, The Rod-shaped Plant Viruses, Vol. 2, pp. 373-395. (Plenum Press, New York, 1986).

Edwards, M.L.; Kelley, S.E.; Arnold, M.K.; Cooper, J.I.: Properties of a hordeivirus from Anthoxanthum odoratum. Plant Pathology 38: 209-218 (1989).

Gustafson, G.; Armour, S.L.: The complete nucleotide sequence of RNAB from the type strain of barley stripe mosaic virus. Nuc. Acids Res. 14: 3895-3909 (1986).

Gustafson, G.; Armour, S.L.; Gamboa, G.C.; Burgett, S.G.; Shepherd, J.W.: Nucleotide sequence of barley stripe mosaic virus RNA $\alpha$ : RNA $\alpha$ encodes a single polypeptide with homology to corresponding proteins from other viruses. Virology 170: 370-377 (1989).

Gustafson, G.; Hunter, B.; Hanau, R.; Armour, S.L.; Jackson, A.O.: Nucleotide sequence and genetic organization of barley stripe mosaic virus RNA $\gamma$. Virology 158:394-406 (1987).

Hunter, B.G.; Heaton, L.A.; Bracker, C.E.; Jackson, A.O.: Structural comparison of poa semilatent virus and barley stripe mosaic virus. Phytopathology 76: 322-326 (1986).

Hunter, B.G.; Smith, J.; Fattouh, F.; Jackson, A.O.: Relationship of lychnis ringspot virus to barley stripe mosaic virus and poa semilatent virus. Intervirology 30: 18-26 (1989).

Jackson, A.O.; Hunter, B.G.; Gustafson, G.D.: Hordeivirus relationships and genome organization. Ann. Rev. Phytopathol. 27: 95-121 (1989). 
Kozlov, Y.V.; Rupasov, V.V.; Adyshev, D.M.; Belgelarskaya, S.N.; Agranovsky, A.A.; Mankin, A.S.; Morozov, S.Yu.; Dolja, V.V.; Atabekov, J.G.: Nucleotide sequence of the 3'-terminal tRNA-like structure in barley stripe mosaic virus genome. Nuc. Acids Res. 12: 4001-4009 (1984).

Partridge, J.E.; Shannon, L.M.; Gumpf, D.J.; Colbaugh, P.: Glycoprotein in the capsid of plant viruses as a possible determinant of seed transmissibility. Nature 247: 391-392 (1974). 
GROUP

RICE STRIPE VIRUS

TENUIVIRUS

Revised by K. Tomaru

\begin{tabular}{lll}
\hline TYPE MEMBER & $\begin{array}{l}\text { RICE STRIPE VIRUS } \\
(\text { RSV })(269)\end{array}$ & - \\
\hline
\end{tabular}

\section{Properties of The Virus Particle}

Morphology Filamentous particles $\approx 8 \mathrm{~nm}$ in diameter and varying lengths, occasionally branched and composed of a supercoiled ribonucleoprotein $\approx 3 \mathrm{~nm}$ diameter.

Physicochemical properties

Nucleic acid

Protein

Lipid

Carbohydrate

Antigenic properties

Host range
Several (2-5) nucleoprotein components each probably containing a single species of RNA distinguished by rate zonal centrifugation in sucrose gradients; buoyant density in $\mathrm{CsCl} \approx 1.28 \mathrm{~g} / \mathrm{cm}^{6}$. Nucleoproteins contain $\approx 5 \%$ RNA.

Four molecules of linear ssRNA (possibly minus sense), $\mathrm{MW} \approx 3.0,1.6,1.1$ and $0.9 \times 10^{6}$ (five ssRNAs of MW $\approx$ $3.01,1.18,0.8,0.78$ and $0.52 \times 10^{6}$ have been reported for another member). Four or five species of dsRNA are also detected in purified virus preparations.

Single coat polypeptide, MW $\approx 32 \times 10^{3}$. Virionassociated RNA-dependent RNA polymerase has been found in purified preparations of type member and the serologically related member, rice grassy stunt virus.

None reported.

None reported.

Serological relationships between some members.

\section{REPLICATION}

Virus particles occur in the cytoplasm and occasionally in the nuclei of leaf cells. Large amounts of a non-structural protein are found in infected cells.

\section{Biological Aspects}

Individual members may have broad host ranges; hosts are restricted to the Gramineae. 
Taxonomic status

English vernacular name

International name

Transmission

Transmitted by leafhoppers in a persistent manner; transovarial transmission by viruliferous females to progeny. Experimental sap transmission difficult.

\section{OTHER MEMBERS}

Maize stripe virus (300)

Rice grassy stunt virus (320)

\section{Possible members}

Echinochloa hoja blanca virus

European wheat striate mosaic virus

Rice hoja blanca virus (299)

Winter wheat mosaic virus

Derivation of tenui: from Latin tenuis, 'thin, fine, weak'.

Name

\section{REFERENCES}

Falk, B.W.; Tsai, J.H.: Identification of single- and double-stranded RNAs associated with maize stripe virus. Phytopathology 74:909-915 (1984).

Falk, B.W.; Tsai, J.H.; Lommel, S.A.: Differences in levels of detection for the maize stripe virus capsid and major non-capsid proteins in plant and insect hosts. J. gen. Virol. 68:1801-1811 (1987).

Falk, B.W.; Morales, F.J.; Tsai, J.H.; Niessen, A.I.: Serological and biochemical properties of the capsid and major noncapsid proteins of maize stripe, rice hoja blanca, and Echinochloa hoja blanca viruses. Phytopathology 77:196-201 (1987).

Gingery, R.E.; Nault, L.R.; Yamashita, S.: Relationship between maize stripe virus and rice stripe virus. J. gen. Virol. 64:1765-1770 (1983).

Toriyama, S.: Ribonucleic acid polymerase activity in filamentous nucleoproteins of rice grassy stunt virus. J. gen. Virol. 68:925-929 (1987).

Toriyama, S.: An RNA-dependent RNA polymerase associated with the filamentous nucleoproteins of rice stripe virus. J. gen. Virol. 67:1247-1255 (1986).

Toriyama, S.: Characterization of rice stripe virus: A heavy component carrying infectivity. J. gen. Virol. 61: 187-195 (1982).

Toriyama, S.; Watanabe, Y.: Characterization of single- and double-stranded RNAs in particles of rice stripe virus. J. gen. Virol. 70: 505-511 (1989). 


\section{SATELLITES}

Compiled by M. Mayo

\begin{tabular}{lll}
\hline TYPE MEMBER & CUCUMBER MOSAIC VIRUS & - \\
& RNA5 (CARNA5) (269) & \\
\hline
\end{tabular}

\section{DEFINITION}

Satellites are nucleic acid molecules that depend for their multiplication on co-infection of a host cell with a helper virus. Satellite nucleic acids have no appreciable sequence homology with their helper virus genome and are not a part of its genome.

\section{DistinCtive Features}

Satellite nucleic acids are distinct from other types of dependent nucleic acid such as sub-genomic nucleic acids (e.g. defective interfering and messenger molecules), genome parts, and transmission-defective but independently replicating viruses. Some satellites may contribute advantageous characters to their helper virus; the distinction between these and genome parts is sometimes not clear-cut.

\section{Classification}

Most reported satellites are associated with plant viruses and these have been arbitrarily classified into four types according to physical and messenger properties of the satellite RNA. These are,

Type A - RNA is large $(>0.7 \mathrm{~kb})$ and encodes a capsid protein that forms satellite-specific particles.

Type B - RNA is large ( $>0.7 \mathrm{~kb})$ and encodes a nonstructural protein.

Type C - RNA is small ( $<0.7 \mathrm{~kb})$, lacks significant mRNA properties and does not form circular RNA.

Type D - RNA is small $(<0.7 \mathrm{~kb})$, lacks mRNA activity and forms circular molecules during replication. 
KNOWN EXAMPLES OF SATELLITES

Most records of satellites are of those associated with plant viruses. Table 1 lists these, together with some of their properties. Satellites have also been found associated with viruses of other taxonomic groups. Examples are bacteriophage $\mathrm{P} 4$, which is a dsDNA satellite virus dependent on bacteriophage $\mathrm{P} 2$, adeno-associated viruses (Dependovirus: Parvoviridae) which are ssDNA satellite viruses dependent on adenoviruses or herpesviruses, hepatitis delta virus which is a large, but circular, satellite RNA dependent on hepatitis B virus and a ssRNA satellite virus which is associated with chronic bee-paralysis virus.

\begin{tabular}{|c|c|c|c|}
\hline Table 1: Plant vir & lites & ted sa & \\
\hline Helper Virus & Virus Group & RNA size & Type \\
\hline Tobacco necrosis & Necrovirus & $1.2 \mathrm{~kb}$ & A \\
\hline Tobacco necrosis & Necrovirus & $0.62 \mathrm{~kb}$ & $\mathrm{C}$ \\
\hline Tobacco mosaic & Tobamovirus & $1.1 \mathrm{~kb}$ & A \\
\hline Panicum mosaic & (unclassified) & $0.8 \mathrm{~kb}$ & A \\
\hline Panicum mosaic & (unclassified) & $0.4 \mathrm{~kb}$ & $\mathrm{C}$ \\
\hline Maize white line mosaic & (unclassified) & c. $1.3 \mathrm{~kb}$ & A \\
\hline Tomato black ring & Nepovirus & $1.4 \mathrm{~kb}$ & B \\
\hline Strawberry latent ringspot & Nepovirus & c. $1.2 \mathrm{~kb}$ & B \\
\hline Arabis mosaic & Nepovirus & $1.1 \mathrm{~kb}$ & B \\
\hline Arabis mosaic & Nepovirus & $0.3 \mathrm{~kb}$ & $\mathrm{D}$ \\
\hline Myrobalan latent ringspot & Nepovirus & c. $1.2 \mathrm{~kb}$ & B \\
\hline Chicory yellow mottle & Nepovirus & $1.1 \mathrm{~kb}$ & B \\
\hline Chicory yellow mottle & Nepovirus & $0.46 \mathrm{~kb}$ & $\mathrm{D}$ \\
\hline Grapevine fanleaf & Nepovirus & $1.1 \mathrm{~kb}$ & B \\
\hline Grapevine Bulgarian latent & Nepovirus & c. $1.7 \mathrm{~kb}$ & B \\
\hline Tobacco ringspot & Nepovirus & $0.3 \mathrm{~kb}$ & $\mathrm{D}$ \\
\hline Beet western yellows & Luteovirus & $3.1 \mathrm{~kb}$ & B \\
\hline Groundnut rosette & (unclassified) & $0.9 \mathrm{~kb}$ & ?B \\
\hline Pea enation mosaic & (monotypic) & c. $0.8 \mathrm{~kb}$ & $? \mathrm{~B}$ \\
\hline Cucumber mosaic & Cucumovirus & $0.3 \mathrm{~kb}$ & $\mathrm{C}$ \\
\hline Peanut stunt & Cucumovirus & $0.4 \mathrm{~kb}$ & $\mathrm{C}$ \\
\hline Turnip crinkle & Carmovirus & $0.2-0.3 \mathrm{~kb}$ & $\mathrm{C}$ \\
\hline Cymbidium ringspot & Tombusvirus & $0.7 \mathrm{~kb}$ & D \\
\hline Tomato bushy stunt & Tombusvirus & $0.7 \mathrm{~kb}$ & $? \mathrm{C}$ \\
\hline Artichoke mottled crinkle & Tombusvirus & $0.7 \mathrm{~kb}$ & $? \mathrm{C}$ \\
\hline Carnation Italian ringspot & Tombusvirus & $0.7 \mathrm{~kb}$ & $? \mathrm{C}$ \\
\hline Petunia asteroid mosaic & Tombusvirus & $0.7 \mathrm{~kb}$ & $? \mathrm{C}$ \\
\hline Pelargonium leaf curl & Tombusvirus & $0.7 \mathrm{~kb}$ & $? \mathrm{C}$ \\
\hline Lucerne transient streak & Sobemovirus & $0.32 \mathrm{~kb}$ & D \\
\hline Velvet tobacco mottle & Sobemovirus & $0.37 \mathrm{~kb}$ & D \\
\hline Solanum nodiflorum mottle & Sobemovirus & $0.38 \mathrm{~kb}$ & D \\
\hline Subterranean clover mottle & Sobemovirus & $0.33+0.39 \mathrm{~kb}$ & $\mathrm{D}$ \\
\hline Barley yellow dwarf & Luteovirus & $0.32 \mathrm{~kb}$ & $\mathrm{D}$ \\
\hline
\end{tabular}




\section{REFERENCES}

Ball, B.V.; Overton, H.A.; Buck, K.W.; Bailey, L.; Perry, J.N.: Relationships between the multiplication of chronic bee-paralysis virus and its associate particle. J. gen. Virol. 66: 1423 - 1429 (1985).

Demler, S.A.; de Zoeten, G.A.: Characterization of a satellite RNA associated with pea enation mosaic virus. J. gen. Virol. 70: 1075-1084 (1989).

Falk, B.W.; Chin, L.-S.; Duffus, J.E.: Complementary DNA cloning and hybridization analysis of beet western yellows luteovirus RNAs. J. gen. Virol. 70: 1301-1309 (1989).

Francki, R.I.B.: Plant virus satellites. Ann. Rev. Microbiol. 39: 151-174 (1985).

Fritsch, C.; Mayo, M.A.: Satellites of plant viruses. In Mandahar, C.L. (ed.), Plant Viruses, Structure and Replication, Vol. I, pp. 289-321 (CRC Press, Boca Raton, Fl., 1989).

Miller, W.A.; Hercus, T.; Waterhouse, P.M.; Gerlach, W.L.: Characterization of a satellite RNA associated with a luteovirus. Abst. VII Int. Congress of Virology, Edmonton, p299 (1987).

Murant, A.F.; Mayo, M.A.: Satellites of plant viruses. Ann. Rev. Phytopathol. 20: 49-70 (1982).

Murant, A.F.; Rajeshwari, R.; Robinson, D.J.; Raschke, J.H.: A satellite RNA of groundnut rosette virus that is largely responsible for symptoms of groundnut rosette disease. J. gen. Virol. 69: 1479-1486 (1988).

Piazolla, P.; Rubino, L.; Tousignant, M.E.; Kaper, J.M.: Two different types of satellite RNA associated with chicory yellow mottle virus. J. gen. Virol. 70: 949-954 (1989).

Six, E.W.; Klug, C.A.C.: Bacteriophage P4: a satellite virus depending on a helper such as prophage P2. Virology. 51: 327-344 (1973).

Wang, K.-S.; Choo, Q.-L.; Weiner, A.J.; Ou, J.-H.; Najarian, R.C.; Thayer, R.M.; Mullenbach, G.T.; Denniston, K.J.; Gerin, J.L.; Houghton, M.: Structure, sequence and expression of the hepatitis delta $(\delta)$ viral genome. Nature 323: 508 - 514 (1986). 


\section{VIROIDS}

Compiled by J.W. Randles and M.A. Rezaian

\begin{tabular}{lll}
\hline TYPE MEMBER & $\begin{array}{l}\text { POTATO SPINDLE TUBER } \\
\text { VIROID (PSTV) }\end{array}$ & - \\
\hline
\end{tabular}

\section{DEFINITION}

Viroids are unencapsidated, low molecular weight, circular, single-stranded infectious RNAs pathogenic to plants.

Physical properties

\section{Chemical properties}

\section{Antigenic properties}

\section{PROPERTIES OF VIROIDS}

Non-denatured viroid molecules adopt extensive internal base pairing to give rod-like structures $\approx 50 \mathrm{~nm}$ long. These denature by cooperative melting to singlestranded circles of $\approx 100 \mathrm{~nm}$ contour length. $\mathrm{MW}=80$ $122 \times 10^{3} ; \mathrm{S}_{20 \mathrm{w}}=8-10 ; \mathrm{Tm}$ in $10 \mathrm{mM} \mathrm{Na}^{+} \approx 50^{\circ} \mathrm{C}$; density in $\mathrm{Cs}_{2} \mathrm{SO}_{4} \approx 1.6 \mathrm{~g} / \mathrm{cm}^{3}$.

Comprise 246 to over 370 nucleotides; all except ASBVd are GC rich with central conserved regions. Oligomers have potential to form palindromic structures involving the upper part of the central conserved region. CCCVd, CLVd, AGVd, CbVd, show sequence rearrangements indicative of probable RNA recombination in viroids. No evidence for encoding protein.

No antigenicity demonstrated.

\section{REPLICATION}

Differ fundamentally from viruses which parasitise host translation; viroids parasitise host transcription possibly using RNA polymerase II. Multimers isolated in vivo may be replicative intermediates produced by a rolling circle mechanism. ASBVd multimers self-cleave in vitro to produce unit length viroid but others do not, and may rely on host factors for cleavage. PSTVd accumulates in nucleoli. 
Taxonomic status

\section{BIOLOGICAL ASPECTS}

Host range Some with wide, others narrow host range in the angiosperms. CCCVd and CTiVd infect monocotyledons, remainder dicotyledons.

Transmission Most distributed by vegetative propagation but some transmissible by seed, aphids, or mechanical damage.

\section{Classification}

Sequences are the primary basis for comparison. The sequence of the central conserved region allows all characterized viroids to be classed into four groups. Variation occurs within each viroid "species" and an arbitrary level of $90 \%$ sequence similarity currently separates variants from species.

\section{OTHER MEMBERS}

\section{Table 1: Grouping viroids using core sequence affinities}

\begin{tabular}{llll}
\hline Viroid & Acronym & Size (Nuc.) & Group \\
Apple scar skin & ASSVd & 330 & ASSVd \\
Australian grapevine & AGVd & 369 & ASSVd \\
Avocado sunblotch (254) & ASBVd & 247 & ASBVd \\
Burdock stunt & BSVd & n.a. & \\
Chrysanthemum stunt & CSVd & 356 & PSTVd \\
Citrus exocortis (226) & CEVd & $370-375$ & PSTVd \\
Coconut cadang-cadang (287) & CCCVd & 246 & PSTVd \\
Coconut tinangaja & CTiVd & 254 & PSTVd \\
Coleus blumei & CbVd1 & n.a. & \\
& CbVd2 & n.a. & \\
& CbVd3 & 248 & \\
Columnea latent & CbVd & n.a. & \\
Grapevine yellow speckle 1 & CLVd & 370 & PSTVd \\
Grapevine yellow speckle 2 & GYSVd 1 & 367 & ASSVd \\
Hop latent & GYSVd 2+ & 363 & ASSVd \\
Hop stunt (326) $*$ & HLVd & 256 & PSTVd \\
Peach latent mosaic & HSVd & $297-303$ & PSTVd \\
Potato spindle tuber (66) & PLMVd & n.a. & \\
Tomato apical stunt & PSTVd & 359 & PSTVd \\
Tomato bunchy top & TASVd & 360 & PSTVd \\
Tomato planto macho & TBTVd & n.a. & \\
\hline
\end{tabular}

* Agent also of cucumber pale fruit, dapple fruit of plum and peach, and isolated from citrus and grapevine.

n.a. not available; + synonymous with GVd1B (Koltunow et al., 1989) 
Possible members

Brazilian coleus viroid

Carnation stunt viroid

Chrysanthemum chlorotic mottle viroid

Citrus viroids

Derivation of Name

viroid: from the name given to the sub-viral RNA agent of potato spindle tuber disease.

\section{REFERENCES}

Diener, T.O.: Potato spindle tuber "virus" IV. A replicating, low molecular weight RNA. Virology 45: 411-428 (1971).

Diener, T.O.: Viroids. Adv. Virus Res. 28: 241-283 (1983).

Duran-Vila, N.; Roistacher, C.N.; Rivera-Bustamante, R.; Semancik, J.S.: A definition of citrus viroid groups and their relationship to the exocortis disease. J. gen. Virol. 69: 3069-3080 (1988).

Hammond, R.; Smith, D.R.; Diener, T.O.: Nucleotide sequence and proposed secondary structure of Columnea latent viroid: a natural mosaic of viroid sequences. Nuc. Acids Res. 17: 10083-10094 (1989).

Hashimoto, J.; Koganezawa, H.: Nucleotide sequence and secondary structure of apple scar skin viroid. Nuc. Acids Res. 15:: 7045-7052 (1987).

Horst, R.K.: Chrysanthemum chlorotic mottle; In Diener, T.O. (ed.), The Viroids (The Viruses), pp. 291-295 (Plenum Press, New York, 1987).

Keese, P.; Osorio-Keese, M.E.; Symons, R.H.: Coconut tinangaja viroid: sequence homology with coconut cadang-cadang viroid and other potato spindle tuber viroid related RNAs. Virology 162: 508-510 (1988).

Keese, P.; Symons, R.H.: Physical-chemical properties: molecular structure (primary and secondary); In Diener, T.O. (ed.), The Viroids (The Viruses), pp. 37-62 (Plenum Press, New York, 1987).

Koltunow, A.M.; Krake, L.R.; Johnson, S.D.; Rezaian, M.A.: Two related viroids cause grapevine yellow speckle disease independently. J. gen. Virol. 70: 3411-3419 (1989).

Koltunow, A.M.; Rezaian, M.A.: A scheme for viroid classification. Intervirology 30: 194201 (1989).

Puchta, H.; Ramm, K.; Sänger, H.L.: The molecular structure of hop latent viroid (HLV), a new viroid occurring worldwide in hops. Nuc. Acids Res. 16: 4197-4216 (1988).

Rezaian, M.A.: Australian grapevine viroid - evidence for extensive recombination between viroids. Nuc. Acids Res. 18: 1813-1818 (1990).

Sano, T.; Hataya, T.; Terai, Y.; Shikata, E.: Hop stunt viroid strains from dapple fruit disease of plum and peach in Japan. J. gen. Virol. 70: 1311-1319 (1989).

Schumacher, J.; Randles, J.W.; Riesner, D.: A two-dimensional electrophoretic technique for the detection of circular viroids and virusoids. Analytical Biochemistry 135: 288-295 (1983).

Spieker, R.L.; Haas, B.; Charng, Y-C.; Freimüller, K.; Sänger, H.L.: Primary and secondary structure of a new viroid "species" (CbVd1) present in the Coleus blumei cultivar "Bienvenue". Nuc. Acids Res. 18: 3998 (1990). 